FERNANDO JACOB NETTO

\title{
TUTELA PROCESSUAL DA POSSE
}

\author{
DISSERTAÇÃO - MESTRADO
}

OrIENTADOREs: Professor Dr. RoQue Komatsu

Professor Dr. Heitor Vitor MENdonça SicA

FACULDADE DE DIREITO DA UNIVERSIDADE DE SÃO PAULO SÃO PAULO 


\title{
FERNANDO JACOB NETTO
}

\section{TUTELA PROCESSUAL DA POSSE}

\begin{abstract}
Dissertação de Mestrado apresentada à Banca Examinadora, no âmbito do Programa de Pós-Graduação da Faculdade de Direito da Universidade de São Paulo, como exigência parcial para obtenção do título de Mestre em Direito, sob a orientação do Professor Dr. Heitor Vitor Mendonça Sica.
\end{abstract}

FACULDADE DE DIREITO DA UNIVERSIDADE DE SÃO PAULO SÃO PAULO 
BANCA EXAMINADORA:

Orientador:

Professor Dr. Heitor Vitor Mendonça Sica

Professor Arguidor:

Professor Arguidor: 


\section{AGRADECIMENTOS}

Pela oportunidade de ingresso no curso de Pós-Graduação dessa Faculdade de Direito da Universidade de São Paulo e auxílio no desenvolvimento do presente trabalho, manifesto meu agradecimento ao Professor Roque Komatsu (in memorian), que, por designo de Deus, não pôde me orientar até a conclusão deste estudo.

Ao Professor Heitor Vitor Mendonça Sica agradeço imensamente por ter me acolhido como seu orientando quando já faltavam apenas seis meses para o depósito desta dissertação, o que não impossibilitou a sua efetiva e valiosa orientação no desenvolvimento do presente trabalho, com a revisão minuciosa de todos os capítulos e a apresentação de críticas, sugestões e ideias que, infelizmente, pela exiguidade do tempo, não pude absorver ao máximo.

Não posso deixar de agradecer de forma especial ao meu pai, Fernando Jacob Filho, por todo o apoio e incentivo que dele sempre recebi, e por ter sido até hoje um exemplo de conduta que tento seguir, sobretudo no exercício da advocacia, atividade que ao longo de sua vida vem desenvolvendo com uma aptidão nata de tratar os problemas de seus clientes como se fossem seus próprios. E pelo exemplo de vida deixado, agradeço ao meu avô Fernando Jacob (in memorian), que, às duras penas, formou-se nessa Faculdade do Largo de São Francisco em 1945 e foi exercer a advocacia no interior de São Paulo, onde ainda hoje é referência por sua formação intelectual e visão humanitária, e pelo brilhantismo com que atuava no Tribunal do Júri.

Agradeço à minha esposa, Suzane, pelo companheirismo no período de elaboração do presente trabalho, e pelo amor que há mais de dez anos nos une, e que certamente nos unirá por toda a vida. À minha mãe, Jane, e às minhas irmãs, Letícia e Viviane, agradeço pelo carinho e apoio incondicional de sempre. 


\section{SUMÁRIO}

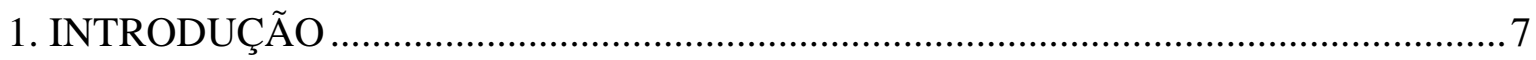

2. POSSE - ASPECTOS DE DIREITO MATERIAL ……………………………….......12

2.1 Perfil histórico da proteção jurídica da posse ...........................................................12

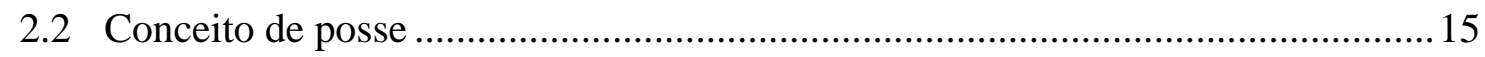

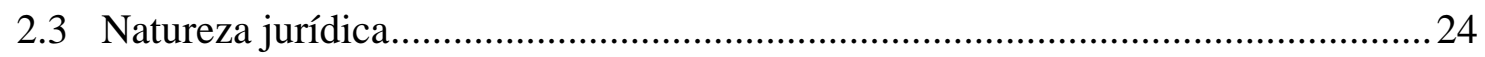

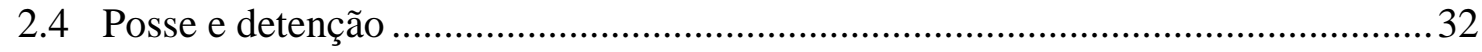

2.5 Classificação da posse ...........................................................................................4

2.5.1 Posse justa e injusta ................................................................................ 41

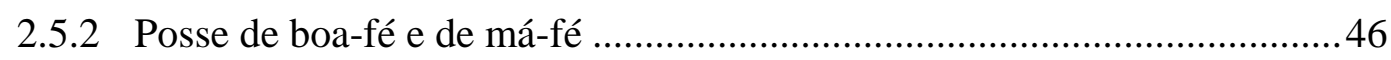

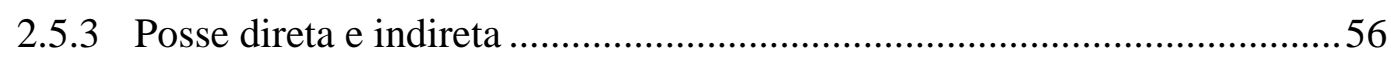

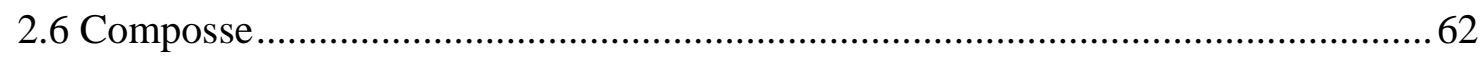

2.7 Aquisição, transmissão e perda da posse .................................................................67

3. TUTELA PROCESSUAL DA POSSE ....................................................................

3.1 Fundamentos da proteção da posse ......................................................................75

3.2 Formas de proteção da posse ............................................................................... 84

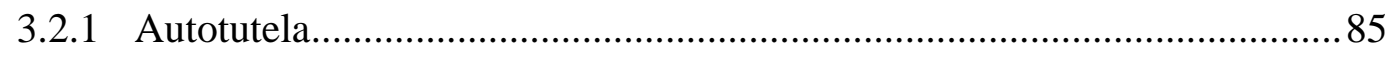

3.2.2 Tutela jurisdicional da posse..................................................................... 87

4. AÇÕES POSSESSÓRIAS TÍPICAS.......................................................................

4.1 Contextualização histórica e definição …………………………………………....... 91

4.2 Reintegração de posse ..................................................................................... 100

4.3 Manutenção de posse ...................................................................................... 115

4.4 Interdito proibitório …………………………………….................................. 122

4.5 Especialidade procedimental: razões para a manutenção do procedimento especial para as "ações possessórias" ........................................................................

4.6 Natureza jurídica das ações possessórias.............................................................. 138

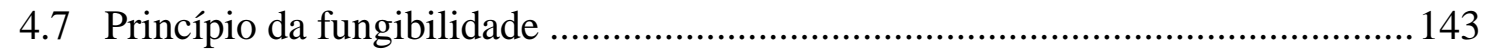

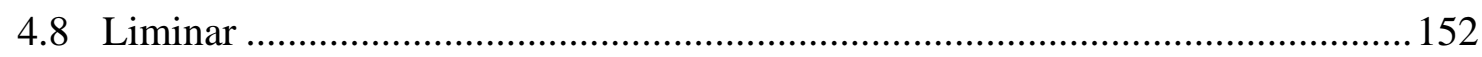

4.8.1 Contexto histórico .............................................................................152 
4.8.2 Natureza da liminar das ações possessórias............................................155

4.8.3 Liminar quanto a posse de “força velha” (procedimento ordinário) ........168

4.8.4 Momento de concessão da liminar nas ações possessórias de "força nova”.

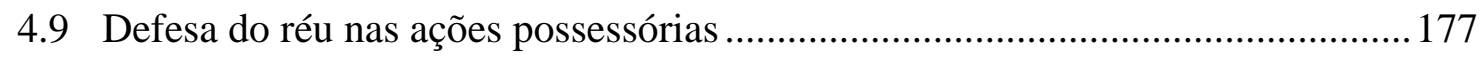

4.9.1 Demanda do réu em contestação (art. 922, CPC) .................................... 179

4.9.2 Vedação à exceção de domínio............................................................... 191

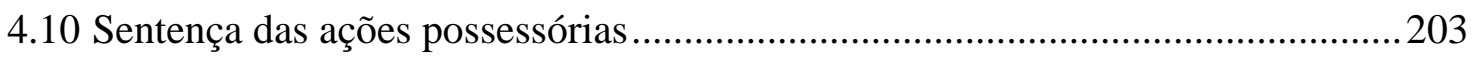

4.10.1 Classificação das tutelas jurisdicionais .................................................... 203

4.10.2 Classificação da tutela jurisdicional outorgada por meio das ações possessórias.

4.10.3 Cumprimento da sentença e defesa do vencido ....................................2220

5. OUTROS REMÉDIOS DE PROTEÇÃO PROCESSUAL DA POSSE .......................2230

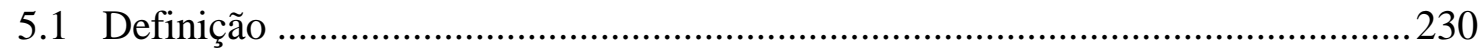

5.2 Ação de nunciação de obra nova, “ação demolitória” e “ação de dano infecto”. 232

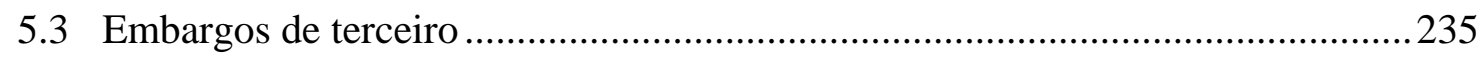

5.4 “Ação de imissão da posse” e “ação reivindicatória” (art. 1.228, CC) .................239

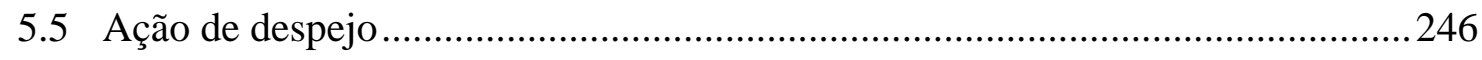

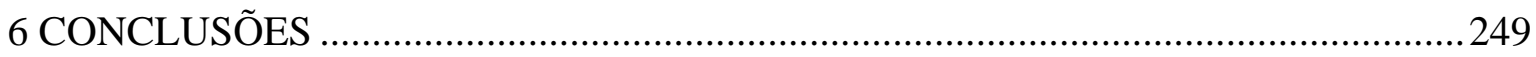

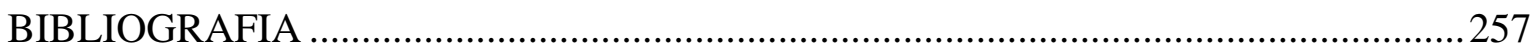

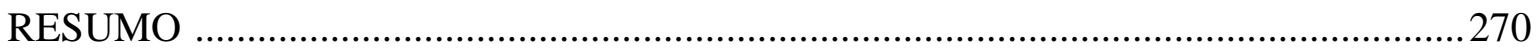

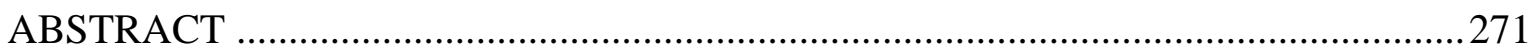




\section{INTRODUÇÃO}

A posse continua sendo um dos temas mais controvertidos para o operador do direito, a começar por seu conceito e pela definição da sua natureza jurídica, e tal dificuldade se estende ao estudo de sua proteção processual.

Desde o direito romano a posse atrai a atenção dos juristas, e ainda na atualidade é um fenômeno de extrema relevância na sociedade, justificando-se, portanto, a utilidade e importância do seu estudo, sobretudo em tempos em que são tão frequentes e acirradas as disputas por terras.

Em relação à proteção processual da posse, causa curiosidade, à primeira vista, a constatação de que o Código de Processo Civil tenha dispensado um tratamento especial às ações possessórias, prevendo a possibilidade de concessão de liminar sem o requisito da urgência - o que demonstra a extrema preocupação do Estado em proteger de forma efetiva e célere a posse -, e que não tenha disponibilizado qualquer tratamento especial, sob o aspecto procedimental, à tutela jurisdicional da propriedade. Não é incomum ouvir, em razão dessa constatação, que a posse assume posição de destaque em relação à propriedade, notadamente no campo do direito processual.

Ainda causa embaraço a observação de que um invasor pode receber do Estado a proteção da posse de um imóvel em desfavor do seu proprietário, o que é plenamente possível, sobretudo depois da alteração trazida pelo Código Civil atual, que não recepcionou a exceptio proprietatis, dispondo que não obsta a manutenção ou reintegração de posse a alegação de propriedade ou outro direito sobre a coisa (art. 1.210, § 2. ${ }^{\circ}$, CC).

A vedação da exceção do domínio pode parecer contraditória com a afirmação de que a posse é a exteriorização da propriedade - concepção difundida pela teoria de Ihering -, sendo estranha à intuição dos leigos e até mesmo dos juristas a possibilidade de procedência da demanda possessória proposta pelo invasor em face do proprietário. 
Entretanto, em verdade, se bem compreendida a teoria formulada por Ihering, a qual foi encampada pelo ordenamento jurídico brasileiro, a posse, que para esse autor nada mais é do que um postulado do direito de propriedade, ou, em outras palavras, a exteriorização da propriedade, deve ser protegida como forma de facilitação da defesa da propriedade.

Questões como essas demonstram como é difícil compreender a posse, seja em relação ao tratamento que lhe é dispensado pelo Código Civil, seja pelas normas que regulam a sua tutela jurisdicional, e ainda maior dificuldade surge quando se tenta explicar o fenômeno possessório sob o aspecto sociológico.

Por isso, o estudo da posse é e deve ser interdisciplinar, envolvendo a análise conjunta dos direitos material e processual, e tanto é assim que a grande maioria dos manuais de direito civil traz comentários sobre as denominadas “ações possessórias”, o que não poderia deixar de ser, dado que o próprio Código Civil faz referência aos interditos possessórios, ao dispor que o possuidor tem direito a ser mantido na posse em caso de turbação e restituído no de esbulho. Aliás, em razão dessa norma, afirma-se que a proteção possessória é o mais importante efeito da posse, e tal afirmação demonstra a falha que decorre do tratamento isolado do instituto pelo direito material, sem compreensão da matéria no campo processual, uma vez que o direito de pedir a tutela jurisdicional não é um mero efeito da posse, mas sim um direito autônomo e dissociado do direito material.

Pode-se notar que as obras que tratam da posse e da sua proteção processual, quando não são manuais, são, em grande maioria, trabalhos de direito civil, que se dedicam prioritariamente aos institutos do direito civil e, de forma secundária e superficial, às questões processuais.

Dessa constatação surgiu o interesse pelo tema do presente trabalho, em que se busca a análise e a compreensão dos institutos processuais relacionados à tutela jurisdicional da posse a partir de um breve exame histórico e com atenção à relação jurídica material.

Embora a posse e a sua tutela jurisdicional sejam um assunto tradicional do Direito, já há muito debatido e explicado, e que à primeira vista revela poucas novidades, é 
certo que justamente por ser um tema antigo faz-se necessária e útil a sua atualização de acordo com as novas concepções do direito civil e processual. Não é possível compreender a posse sem considerar as propostas das teorias contemporâneas, que melhor explicam o fenômeno possessório sob o aspecto social. ${ }^{1}$ De igual modo, é indispensável revisitar determinados conceitos que se arraigaram de maneira irracional na doutrina e na jurisprudência, por exemplo, o entendimento de que o direito de pedir a tutela jurisdicional da posse é mero efeito desta.

Destarte, entende-se que é justificável a realização de estudo sobre a posse e sua proteção processual, não apenas em razão da importância do tema sob o aspecto sociológico, mas principalmente pela persistência de pontos polêmicos na doutrina e pela necessidade de atualização da matéria à luz das novas concepções dos direitos material e instrumental, sobretudo em decorrência das alterações legislativas ocorridas nos últimos anos.

Foram analisados no presente trabalho os principais aspectos históricos e dogmáticos relacionados à posse e à sua proteção processual, considerando os institutos de direito civil que explicam o fenômeno possessório para, a partir daí, tratar das situações surgidas nas denominadas “ações possessórias”.

Assim, ao longo do estudo dos institutos de direito civil e processual, serão considerados os aspectos históricos mais relevantes da posse e da sua tutela processual, com referência aos direitos romano, germânico medieval e canônico, o que permitirá compreender como se deu a formação do direito português relacionado à proteção da posse e a sua evolução até a formação do direito brasileiro, com o advento do Código Civil de 1916.

1 “La posesión no es la propiedad. La posesión puede presentarse en dos situaciones fundamentales: integrada en el derecho de propiedad y como uno de los modos de manifestarse; o bien La posesión sin más, en si, abstracción hecha de si es consecuencia o no de la propiedad o de otro derecho real. Naturalmente, solo en el segundo caso tiene un significado autónomo. Una radicalización de esta autonomía se recoge en la idea, tantas veces repetida, de que la posesión es de hecho lo que la propiedad es de derecho. En rigor no hay una contraposición tan absoluta como la que el simplicísimo terminológico da a entender. Porque también la posesión tiene un valor jurídico, aunque a este, en verdad, le dota de sentido el contenido fáctico" (HERNANDEZ GIL, Antonio. La función social de la posesión. Ensayo de teorización sociológico-jurídica, p. 8). 
Se o estudo da história contribui para a compreensão do direito atual, ${ }^{2}$ em matéria possessória essa contribuição é deveras maior e mais visível, porquanto os interditos, que remontam ao início do direito romano, sofreram influências diversas ao longo da história. A origem e a evolução da posse de ano e dia, por exemplo, que está arraigada ao ordenamento jurídico brasileiro, são completamente desconhecidas pela maioria dos juristas, e o estudo histórico permite compreender o porquê da sua manutenção e também a razão pela qual constitui limitador temporal para a concessão de liminar no processo possessório e requisito para a utilização do procedimento especial.

A superação da fase autonomista da ciência processual - segundo momento metodológico ${ }^{3}$ do direito processual - trouxe a consciência de que o processo, enquanto instrumento posto à disposição do jurisdicionado para a solução de litígios por meio da atuação da lei, tem íntima relação com o direito material a ser tutelado, sendo imprescindível, portanto, o estudo do processo à luz das relações de direito material.

Partindo dessa premissa, tem-se como indispensável o estudo dos institutos de direito civil relacionados à posse para entender e explicar os desdobramentos ocorridos no campo processual. A posse direta e indireta, a composse, o constituto possessório, entre outros, são institutos que devem ser compreendidos porque invariavelmente acarretam controvérsias no processo, tanto em relação à adequação ou não das ações possessórias quanto à legitimidade e ao interesse processual.

Tais apontamentos demonstram que o caráter instrumental do processo exige que seus institutos sejam adequados às necessidades do direito substancial, pois as relações

2 “[...] quem quiser compreender qualquer ordenamento jurídico, deverá desdobrar o seu estudo em várias etapas: deverá dirigir sua atenção para o conteúdo de suas normas e instituições; para as condições temporais em que esse ordenamento jurídico surgiu; e para a questão da efetividade desse ordenamento na sociedade que lhe corresponde: isto é, deverá certificar-se de que aquelas normas e instituições ainda se encontram atuantes; se não, porque deixaram de prevalecer; ou ainda, porque não exercem a sua influência com igual intensidade” (CRUZ E TUCCI, José Rogério; AZEVEDO, Luiz Carlos. Lições de história do processo civil romano, p. 22).

3 DINAMARCO, Cândido Rangel. A instrumentalidade do processo, p. 22. 
entre direito material e processo "são intensas e o perfeito conhecimento do processo depende da correta identificação desse nexo". 4

Em seguida à análise dos institutos de direito material, dedicamos um capítulo ao estudo das “ações possessórias”, dentre as quais se incluem a ação de reintegração de posse, a de manutenção e o interdito proibitório, todas previstas no Capítulo V do Livro de Procedimentos Especiais do Código de Processo Civil, bem como dos institutos de direito processual relacionados à matéria.

Analisamos, ainda, os denominados remédios processuais de proteção da posse, ou ações possessórias lato sensu, ${ }^{5}$ assim compreendidas as medidas judiciais que, embora possam ter como objeto a proteção possessória, fundamentam-se também ou exclusivamente no direito de propriedade, como a ação de nunciação de obra nova, os embargos de terceiro, a denominada “ação reivindicatória”, entre outras, que serão tratadas apenas com o intuito de permitir a comparação e a identificação das diferenças em relação aos interditos possessórios.

4 BEDAQUE, José Roberto dos Santos. Direito e processo. Influência do direito material sobre o processo, p. 19.

5 “[...] possessórias lato sensu, as quais, eventualmente, podem fundar-se na posse, mas não necessariamente [...] ações que não se destinam única e exclusivamente à proteção possessória, ou que não tenham como possibilidade de fundamento jurídico exclusivamente o direito de posse” (CIMARDI, Cláudia Aparecida. Proteção processual da posse, p. 72-73). 


\section{POSSE - ASPECTOS DE DIREITO MATERIAL}

Não é exagerada a afirmação de Caio Mário da Silva Pereira de que “a posse parece condenada a sofrer a maldição das controvérsias”, 6 pois as divergências surgem já na sua conceituação, e recaem sobre praticamente todas as questões a ela atinentes, como a sua origem história, o fundamento para a sua proteção processual, natureza jurídica, classificação, entre outras.

Nos próximos tópicos serão apresentados alguns aspectos históricos e dogmáticos relacionados à posse, com o intuito de remontar às teorias que trataram desse instituto, desde as clássicas teorias de Ihering e Savigny até as teorias contemporâneas, e também para investigar qual a orientação atual sobre tais questões no sistema jurídico brasileiro.

\subsection{Perfil histórico da proteção jurídica da posse}

A posse é anterior à propriedade e a qualquer ato jurídico, pois representa a forma originária de apropriação e utilização da coisa. ${ }^{7}$ Immanuel Kant afirma que qualquer porção de terra pode ser objeto de aquisição originária, e que o fundamento da possibilidade desta aquisição é a comunidade originária da terra em geral. Para explicar essa proposição, Kant sustenta que a posse em comum originária (communio possessionis

6 PEREIRA, Caio Mário da Silva. Instituições de direito civil. v. 4. Direitos reais, p. 32.

7 Ao contrariar a teoria de Ihering sobre a conceituação da posse como exteriorização da propriedade, Renan Falcão de Azevedo traz interessante explicação sobre a origem da posse: "O homem primitivo, como os animais, se apoderavam de bens capazes de satisfazer suas necessidades. Assim acontecia com a caça, a pesca, a feitura de instrumentos que transformava em abrigo ou armas. Claro, na pré-história do direito, não havia qualquer espécie de regulamentação que legitimasse socialmente este apoderamento. Sem embargo, ele existia. E o nosso antepassado primata consumia estes bens, deles se apoderava de forma exclusiva, usando-os e deles dispondo. Estava, como se vê, exercendo uma forma de domínio, vale dizer: uma forma primitiva de propriedade, muito embora a propriedade estivesse a séculos de distância de seu reconhecimento como direito. De qualquer forma, é irrecusável que o homem primitivo já dispunha dos bens de que se apoderava. Evidentemente, esta disposição não correspondia a nenhuma legitimação jurídica. O que a mantinha respeitada pelos outros não era outra coisa que a forma e a precedência no apoderamento dos bens. Se este apoderamento era feito de forma individual ou coletiva, como nas organizações do chamado comunismo primitivo, isto em nada altera os fatos. [...] a posse não nasceu como sinal exterior do direito de propriedade, pois isto implicaria em reconhecer a preexistência da mesma propriedade, da qual fosse a posse mera consequência” (AZEVEDO, Renan Falcão de. Posse: efeitos e proteção, p. 34). 
originaria) “é um conceito prático da razão que contém a priori o princípio segundo o qual somente os homens podem fazer uso em conformidade com leis jurídicas do lugar que ocupam sobre a terra”. 8

Na mesma linha de Kant, Rosenvald assevera que “a origem da posse é historicamente justificada no poder físico sobre as coisas e na necessidade do homem se apropriar de bens", 9 sendo certo que essa apropriação e a conservação da posse foram preponderantes para a formação da civilização ocidental, dado que o homem iniciou o desenvolvimento a partir do momento em que passou a se fixar em um determinado espaço para exercer suas atividades de forma contínua, o que certamente antecedeu o direito de propriedade, uma vez que primeiro o homem se apossou dos bens, e só depois deste apossamento deles se “adonou”. ${ }^{10}$ Nesse passo, os historiadores tentam encontrar qual teria sido especificamente a situação de fato que deu origem à sua proteção jurídica.

Pouca certeza se tem sobre o nascimento da posse para o direito, mas há teorias diversas que tentam explicá-lo. Segundo Astolpho Rezende, é com pouca certeza e precisão que se trata da primeira parte da historia romana. ${ }^{11} \mathrm{O}$ que parece, segundo o autor, é que a propriedade do solo era coletiva e pertencia às gentes. A gens era uma instituição formada por um grupo de pessoas ligadas politicamente a uma autoridade comum, o denominado Pater Gentis, e cada gens ocupava um território. Logo, o Estado Romano teria sido formado a partir da junção dessas coletividades existentes anteriormente.

Depois do início das conquistas de terras pelo Estado, passou a existir, ao lado da propriedade territorial das gentes, a propriedade territorial do Estado; o solo era, por direito de conquista, propriedade do Estado, e insuscetível de aquisição por particulares. Apesar disso, o Estado não utilizava diretamente todas as terras conquistadas, mas as distribuía por meio de concessões.

8 KANT, Immanuel. A metafísica dos costumes, p. 263.

9 ROSENVALD, Nelson; FARIAS, Cristiano Chaves de. Direitos reais, p. 27.

10 AZEVEDO, Renan Falcão de. Posse: efeitos e proteção, p. 35.

11 "A história dos cinco primeiros séculos da história romana tradicionalmente não nos é acessível senão através de obras muito posteriores, das quais as mais antigas são do tempo de Cesar e de Augusto" (REZENDE, Astolpho. A posse e sua proteç̧ão. v. 1, p. 22). 
Dessa forma, algumas pessoas adquiriam as terras por deliberação própria, naturalmente, enquanto outras as obtinham por meio de título regular, como concessão, doação ou herança. Denominava-se, uma e outra, ager publicus e ager privatus, de modo a diferenciar a propriedade privada e aquela pertencente ao Estado e concedida a terceiros.

Da ager publicus teriam surgido a posse e sua proteção jurídica, na medida em que os particulares, não tendo o direito de propriedade sobre essas áreas, não dispunham da ação reivindicatória, mas precisavam de algum modo defender a sua permanência nas terras. Para explicar como teria surgido a posse, Savigny cita Niebhur:

Havia, sob a República, duas espécies de terras: o ager publicus e o ager privatus. Só este era suscetível de propriedade. Em relação ao ager pubilcus, também se concedia, entretanto, segundo a antiga Constituição, a posse e o gozo aos cidadãos romanos, mas conservando sempre o direito de revogar a concessão a qual tempo. ${ }^{12}$

Assim, Savigny conclui que a posse que dava direito aos interditos foi precisamente a forma legal destinada a proteger o ager publicus. Os cidadãos romanos que recebiam essas áreas em concessão tinham o direito de usufruir da terra, mas por vezes eram vítimas da arbitrariedade do Estado, que revogava a concessão antes mesmo das colheitas. Para proteger os cidadãos romanos contra a revogação indevida das concessões, e também contra a violência de terceiros que se investiam indevidamente contra a posse dessa área insuscetível de propriedade privada, o Pretor começou a tutelar a posse por meio dos interdicta. ${ }^{13}$

12 "Esta origen de la posesión há sido explicado del modo más satisfactorio por Niebhur. Había en la república romana dos clases de tierras; el ager publicus y el ager privatus, que era el único que podia venir a ser objeto de propiedad privada. El ager publicus se concedia también, no obstante, según la antigua constitución, a simples cuidadanos romanos, para su posesión y usufruto, pero conservando siempre la república el derecho de recobrarlo em cualquier tempo" (SAVIGNY, M.F.C. de. Tratado de la posesión, p. 130.

13 "Anche nelle fonti surriportate trova conforto l'ipotesi, da ultimo sviluppata particolarmente dal Kaser, secondo cui la possessio è presumibilmente sorta dal possesso delle terre originariamente appartenenti alle collettività gentilizie e poi al populus Romanus, sulle quali al singolo pater familias no era reconosciuta una piena proprietà privata ma solo um potere derivato. Ancora in età storica sull'ager publicus, ogetto di dominio eminente del popolo romano, in quanto non attribuito tramite apposite forme (datio adsignatio) in proprietà privata a singoli, è riconosciuta a questi soltanto una possessio revocabile dall'autorità pubblica, ancorché tutelata verso i terzi privati” (BURDESE, Alberto. Enciclopedia del Diritto, p. 452). 
Segundo Ribas, ${ }^{14}$ era inevitável que muitas vezes os possuidores fossem perturbados, ou espoliados, por atos arbitrários, o que tornou indispensável a intervenção da autoridade pública para fazer cessar esses atos, tendo sido esta consideração de ordem pública que levou o Pretor a proteger, por meio dos interditos, a posse do ager publicus.

Ihering contraria essa teoria, e nega a criação dos interditos a partir da equiparação do ager publicus e ager privatus. Para esse autor, é falsa a teoria de Neibuhr, de que a proteção possessória deriva do ager publicus. Segundo Ihering, a teoria possessória surgiu da domus romana (casa romana) - a propriedade não era concebida como um direito individual, mas como um direito de família -, e da relação entre proprietário e rendeiros e locatários, visto que estes últimos eram considerados meros detentores, não podendo ser protegidos contra os abusos dos senhores.

A partir disso, Ihering defendeu que a proteção possessória teria surgido da faculdade que tinha o pretor de, nas ações de reivindicação, atribuir a posse provisória da coisa ao autor, até que viesse a sentença final.

Independentemente da teoria que se escolha por correta (domus romana ou ager publicus), nota-se que a posse se originou de forma espontânea na sociedade, podendo ser compreendida como um instituto paralelo, complementar ou até, em casos excepcionais, contrário ao direito de propriedade, ${ }^{15}$ mas certamente antecedente a esta.

\subsection{Conceito de posse}

A posse é, antes de tudo, uma situação de fato que se instaura naturalmente entre os homens, um fato inevitável na sociedade, que ganha relevância para o direito a partir do momento em que é protegida pelo Estado. Nas palavras de Astolpho Rezende, posse é “a relação de fato que confere a uma pessoa a possibilidade de exercer sobre uma coisa

\footnotetext{
14 RIBAS, Antônio Joaquim. Da posse e das ações possessórias, p. VI.

15 ARAÚJO, Fabio Caldas de. Posse, p. 7.
} 
material atos de gozo, de uso ou de transformação”. É, portanto, um estado de fato protegido por lei e gerador de uma série de consequências jurídicas. ${ }^{16}$

A forma como entendemos a posse atualmente resulta da combinação de princípios romanos e germânicos. ${ }^{17}$

Quanto ao direito romano, não se pode imaginar um único conceito de posse, visto que em cada uma de suas fases a posse foi encarada de maneira diversa, o que acarretou divergências nas teorias moderna e contemporânea sobre a posse, uma vez que alguns juristas se filiam na posse como entendida em uma determinada fase do direito romano, e outros buscam em outra fase as explicações para suas dúvidas. ${ }^{18}$

Ao tratar da evolução por que passou a teoria da posse no direito romano, José Carlos Moreira Alves ${ }^{19}$ faz referência ao romanista italiano E. Albertario, que, em sua obra Il Possesso, in Studi di Diritto Romano, fixa três épocas em que se deve examinar a evolução do conceito de posse em Roma: a pré-clássica, a imperial clássica e a justinianeia.

Segundo o autor, na época republicana, ou pré-clássica, a posse era considerada uma senhoria de fato sobre a coisa, sobre a qual o concedente conservava a senhoria de direito, não podendo nunca a senhoria de fato se transformar em senhoria de direito. Já na segunda época, a imperial clássica, a posse é senhoria de fato que se baseia nos elementos objetivo (possessio corpore) e subjetivo (animus possidendi), e é capaz de conduzir à aquisição da senhoria de direito. No terceiro período, aparece, ao lado da posse da coisa, a posse de direito (possessio iuris), o que faz com que a noção de posse se altere, passando a ser considerada como o exercício do direito de propriedade ou de qualquer outro direito

\footnotetext{
16 "La posesión es un estado de hecho protegido por la ley y al que ésta liga una serie de concuencias jurídicas” (BARASSI, Lodovico. Instituiciones de derecho civil, p. 101).

17 "El actual derecho de posesión se basta en una combinación de principios del derecho romano y del germánico" (WOLFF, Martín. Tratado de derecho civil. t. III, $1^{\circ}$. Derecho de cosas, p. 34).

18 "Uma das causas da inconciliável polêmica reside, certamente, no fato de haver a codificação justinianeia resumido textos de períodos vários (primeiros monumentos, república, época pré-clássica e clássica), associando-se ainda às teses bizantinas e medievais, cada tempo sofrendo a contribuição de fatores socioeconômicos diversificados e diversificantes” (PEREIRA, Caio Mário da Silva. Instituições de direito civil. v. 4. Direitos reais, p. 12).

19 MOREIRA ALVES, José Carlos. Posse. Evolução histórica, p. 10.
} 
real e, assim, associa-se a posse a um estado de direito, levando-se em conta a intenção do sujeito conforme o direito (animus domini) e desprezando-se a disponibilidade da coisa.

No direito germânico medieval, a Gewere - palavra que pode ser traduzida para o português como “investidura” - correspondia à possessio romana, muito embora tal denominação fosse empregada em outros sentidos, o que nos impede igualar tais institutos. ${ }^{20}$ Apesar das divergências doutrinárias sobre o seu exato significado, é pacífica a conclusão de que tal instituto representava a relação de senhoria entre pessoa e coisa, a expressão de fato da dominação sobre uma coisa, ${ }^{21}$ e que decorre da recepção do direito romano na Alemanha por volta do século XVI.

Para Martin Wolff, a Gewere do direito medieval alemão é igual ao fato da posse no direito moderno, por se tratar de puro senhorio de fato sobre a coisa. ${ }^{22}$ Contudo, a permanência de uma pessoa na posse de um imóvel por um ano e um dia acarretava, no direito germânico medieval, a transformação da Gewere em rechte Gewere, ou seja, ao completar esse período, a posse adquiria estabilidade e favorecia o seu titular na defesa contra esbulho ou qualquer outra ameaça; não se confunde a rechte Gewere com a usucapio do direito romano, pois não significava a transformação de fato em direito, mas tão somente a transformação de posse sujeita a contestação em posse incontestável. Moreira Alves afirma que a rechte Gewere "tem, no direito germânico medieval, a mesma

${ }^{20}$ O doutrinador brasileiro Astolpho Rezende, em sua célebre obra "A posse e sua protecção”, defende: “a Gewere germânica não era a posse. Ella comprehendia dois gráus bem disctintos: $10^{\circ}$, a simples detenção de uma coisa que, para os móveis, comprehendia o que se chamava a simples Gewere; 2. ${ }^{\circ}$, no caso e immoveis, para os quaes a simples detenção não bastava, a posse apoiada num motivo jurídico, num justo título, rechte Gewere; neste caso a acção era realmente fundada na posse, mas na justa possessio, o que a transformava radicalmente, e fazia della uma acção petitória" (REZENDE, Astolpho. A posse e sua proteç̧ão. v. 1, p. 439).

21 “[...] por muito tempo foi a Gewere tida pelos juristas alemães como o equivalente da posse romana no direito germânico medieval, razão por que era considerada instituto extinto e apenas digno de curiosidade histórica. Foi a obra de Savigny que, caracterizando a posse romana como senhoria física sobre a coisa, despertou a atenção da doutrina alemã para a Gewere, pois, ocorrendo esta em várias hipóteses em que não havia esse poder, ficou evidenciado que não existia a equivalência." "Note-se que, no direito romano vulgar (que, na época pós-clássica, é o direito romano vivo, aplicado na prática, adaptado às necessidade da vida, em face do direito elaborado, técnico, que é o direito oficial - o direito escrito -, estando para este como o latim vulgar está para o latim literário), a possessio e a Gewere apresentaram várias semelhanças, postas em relevo por Levy, West Roman Vulgar Law - The Law of Property, pags. 96 a 99)” (MOREIRA ALVES, José Carlos. Posse. Evolução histórica, p. 75 e 313).

22 “La 'Gewere’ (besittinge) del derecho medieval alemán es, al igual que el hecho de la posesión sobre una cosa” (WOLFF, Martín. Tratado de derecho civil. t. III, $1^{\circ}$. Derecho de cosas, p. 34). 
importância de que desfrutava o usucapião no direito romano", ${ }^{23}$ mas reconhece que tal instituto não se confunde com a usucapio.

O direito canônico desenvolveu o conceito de posse de direitos oriundo da fase justinianeia do direito romano, e o estendeu a todos os direitos de ordem pública, privada, pessoal ou real, que pudessem se submeter ao exercício de fato. Como destaca Eduardo Espínola, o direito canônico contribuiu para a moderna concepção do instituto pelo reconhecimento da posse dos bens incorpóreos, ampliando a esfera da quase possessio romana, e pela proteção do detentor contra o esbulho. ${ }^{24}$

Já no direito português reinol houve diferença acerca do conceito de posse nas suas diversas fases, tendo havido influências, em um primeiro momento - período da Reconquista -, das tradições germânicas, seguindo-se então a fase do renascimento do direito romano na península ibérica, fenômeno que se inicia nos primórdios do século XIII e impõe mudanças significativas no direito português dos séculos seguintes. ${ }^{25}$

Assim, o tratamento da posse no direito português do período da reconquista é marcado pela influência da tradição germânica, que não distingue posse e propriedade e não estabelece uma disciplina diversa para a posse de bens móveis, que legitimava a sua aquisição desde que não fossem os bens roubados ou perdidos (mobilia non habent sequelam). Somente com o renascimento do direito romano justinianeu em Portugal, na segunda metade do século XIII, é que voltam para a península ibérica os conceitos romanos no tocante à posse, com a nítida distinção entre posse e propriedade, a exigência de boa-fé, o reconhecimento da prescrição aquisitiva, a usucapio do direito romano.

23 MOREIRA ALVES, José Carlos. Posse. Evolução histórica, p. 91.

24 ESPÍNOLA, Eduardo. Posse - Propriedade. Compropriedade ou condomínio. Direitos autorais. Conquista, p. 42.

25 O tratamento da posse no direito português do período da reconquista é marcado pela influência da tradição germânica, que não distingue posse e propriedade e, tampouco, reivindicação e ação possessória, bem como não estabelece uma disciplina diversa para a posse de bens móveis, que legitimava a sua aquisição desde que não fossem os bens roubados ou perdidos (mobilia non habent sequelam). Somente com o renascimento do direito romano justinianeu em Portugal, na segunda metade do século XIII, é que voltam para a península ibérica os conceitos romanos no tocante à posse, com a nítida distinção entre posse e propriedade, a exigência de boa-fé, o reconhecimento da prescrição aquisitiva, a usucapio do direito romano, e a subtração dos limites para a reivindicação das coisas móveis. 
A partir dessas referências históricas pontuais, e sobretudo dos conceitos de posse nas diversas fases do direito romano, é possível tirar a explicação para as divergências entre as inúmeras teorias existentes sobre o tema. Conclui-se, como se verá adiante, que Savigny, defensor da teoria subjetiva da posse, ateve-se à noção do direito clássico ao tratar do animus domini, ${ }^{26}$ e que Ihering se baseou na causa possessionis, que no direito clássico foi a base para a distinção entre possessio civilis e possessio ad interdicta.

Quando Savigny, em 1803, publicou o seu livro O direito de posse, a doutrina sobre o tema era bastante confusa, e o autor tinha como objetivo expor a teoria da posse como ela se apresentava no direito romano. Portanto, tratava-se de uma obra voltada para a reconstrução da teoria da posse como haviam concebido os jurisconsultos romanos, e não de um trabalho destinado a fins práticos.

A sua teoria, desenvolvida a partir daí, baseia-se fundamentalmente na importância atribuída ao animus, ao elemento subjetivo, que, ao lado do corpus, configuraria a posse. O corpus, inicialmente, era o contato físico com a coisa, mas depois a própria teoria subjetiva evoluiu para admitir que o elemento corpus era a mera possibilidade de dispor fisicamente da coisa, e de defendê-la contra agressões de terceiros.

O animus que caracteriza a posse, segundo seu entendimento, é o animus domini (a intenção de ter a coisa como sua), que é diferente da opinio domini (crença de ser o proprietário). E, assim, Savigny defende que a posse "é poder que tem a pessoa de dispor fisicamente de uma coisa, com intenção de tê-la para si e de defendê-la contra a intervenção de outrem”. ${ }^{27}$

Portanto, segundo a teoria de Savigny, a situação de ter a coisa com o reconhecimento da propriedade alheia configuraria mera detenção, e não posse. E justamente nesse ponto é que recaíram as maiores críticas à sua teoria, dado que reduzia

26 "Merece particular consideração o período clássico, ao qual se aplica a sistematização de Savigny, segundo o qual a simples detenção, corpus, sem a vontade de ter a coisa como sua, isto é, sem animus domini não é posse [...] além desta manifestação de vontade de deter a coisa, a doutrina clássica requer um animus especial para que haja posse - o animus rem sibi habendi - a vontade de tê-la como sua" (ESPÍNOLA, Eduardo. Posse - Propriedade. Compropriedade ou condomínio. Direitos autorais. Conquista, p. 36)

27 BARROS MONTEIRO, Washington de; MALUF, Carlos Alberto Dabus. Curso de direito civil. v. 3. Direito das coisas, p. 28. 
credor pignoratício, o comodatário, o inquilino, o depositário, o enfiteuta etc. a meros detentores, enquanto o ladrão, que roubasse a coisa e passasse a detê-la com a intenção de tê-la como sua, seria possuidor.

Diante disso, a teoria subjetiva se mostrou falha, o que levou Savigny a buscar uma alternativa para consertá-la. Foi então que ele criou a denominada "posse derivada”, que se configura com a transferência dos direitos possessórios.

No entanto, criando essa tese para tornar possuidor o credor pignoratício, ele acaba por contrariar o seu pensamento principal, admitindo a posse sem a intenção de ser dono, sem animus domini, o que fez com que sua teoria caísse no descrédito.

Apesar disso, é inquestionável a importância da obra de Savigny, tanto pela análise das fontes romanas quanto pela inovação do tratamento global dado à posse.

Entretanto, já no ano de 1825 se iniciaram os ataques à teoria de Savigny, principalmente no tocante ao animus domini. Alguns autores discordavam da ideia da posse derivada por entenderem que também ali existia uma ficção do animus domini estabelecida pelo direito positivo. Outros tentavam mudar o conceito de animus domini para alcançar a situação da posse derivada. Na sexta edição de seu livro, publicada em 1836, Savigny analisa as críticas feitas à sua teoria, mas não elimina a controvérsia.

Em 1868, após a morte de Savigny, portanto, Ihering começa a divulgar estudos sobre a posse, e em 1889 publica a sua obra completa que combate de forma madura e definitiva a teoria subjetiva de Savigny.

Ihering entendia que apenas o corpus constitui a posse, e que o animus se acha implícito no poder de fato exercido sobre a coisa, no corpus. Muitos autores ${ }^{28}$ afirmam que Ihering não nega a existência da vontade, mas apenas deixa de privilegiar esse elemento anímico, que na teoria subjetiva era colocado em evidência. No entanto, Ihering sustenta que o corpus é o único elemento visível e suscetível de comprovação, e que a vontade

\footnotetext{
28 “Ao traduzir a ideia de Ihering, Vicente Ráo sustenta que "o corpus não pode existir sem o animus, nem o animus sem o corpus”. Afirma o autor, ainda, que "ambos nascem ao mesmo tempo pela incorporação da vontade na relação com a cousa” (RÁO, Vicente. Posse de direitos pessoaes, p. 10).
} 
nenhuma importância tem no reconhecimento da posse, ${ }^{29}$ o que inclusive motivou severa crítica de Rodrigues de Meréje. ${ }^{30}$

Além disso, Ihering defende que a posse é a exteriorização da propriedade, ${ }^{31}$ e estreita a relação entre os dois institutos, sempre reconhecendo a distinção entre ambos, mas entendendo que a posse é um complemento do sistema da propriedade, e que a proteção da posse só existe em razão da propriedade.

Após as teorias de Savigny e de Ihering, revelaram-se outras concepções sobre a posse. Primeiro, surgiu a teoria da apropriação econômica, que tem como principal diferença a tentativa de desvencilhar a posse da propriedade, contrapondo-se, portanto, à teoria objetiva. O representante dessa nova teoria foi o autor francês Raymond Saleilles, que sustentou que a posse era uma "relação durável de apropriação econômica, uma relação de exploração da coisa a serviço do indivíduo". ${ }^{32}$ Defendeu o autor francês que a proteção da posse se legitima não em homenagem ao direito de propriedade, mas como um direito decorrente apenas da posse em si mesma.

Tal ideia representa o que antes de Saleilles já se denominava de teoria absoluta da posse, segundo a qual "a posse não deve sua proteção e importância a considerações que lhe são estranhas; é por si que ela se torna reconhecida juridicamente e o Direito não lhe pode recusar este reconhecimento". 33

29 “É uma vã sutileza objetar-se que essas pessoas não têm a vontade de possuir. De ordinário não têm a menor noção da diferença que existe entre a detenção e a posse jurídica e a sua vontade de possuir em nada difere da das outras pessoas acima indicadas. Dir-se-á que não pode ter essa vontade. Daí resultará que o motivo pelo qual se recusa a posse não está na sua vontade, mas nas regras de direito.”

30 “O desconhecimento da genisis do Código Civil, a ignorância completa das fontes em que se abeberam os nossos legiferantes, conduz a esse disparate, de se falar em animo domini, no direito brasileiro! [...] A teoria criada por Ihering nos seus últimos trabalhos (já mencionados por Clóvis), conduz a excluir absolutamente qualquer ideia de animus dominis ou de animus possidendi. Não existe outra vontade senão a que acompanha necessariamente cada fato de detenção, outra intenção além daquela de se servir da coisa” (MERÉJE, Rodrigues de. Teorias jurídicas da posse, p. 99).

31 "Entendo por exterioridade da propriedade o estado normal externo da cousa, sob a qual se cumpre o destino economico de servir aos homens. Esse estado toma, segundo a diversidade das cousas, um aspecto exterior diferente; para umas, confunde-se com a detenção ou posse physica da cousa; para outras, não” (JHERING, Rudolf von. O fundamento dos interdictos possessorios, p. 231).

32 SALEILLES, Raymond. La posesión: elementos que la constituyen y su sistema en el Código Civil Del Imperio Alemán. p. 46.

33 IHERING, Rudolf von. O fundamento dos interdictos possessorios, p. 11. 
Entre as teorias de Savigny e de Ihering, o que há de essencial e que fez com que a teoria objetiva superasse a subjetiva é a divergência em relação ao conceito e aos elementos da posse, mais especificamente a importância atribuída ao animus na conceituação da posse. Savigny, ao defender que o animus domini seria elemento integrante da posse, ao lado do corpus, não conseguiu explicar a situação do comodatário, do enfiteuta, do credor pignoratício e do locatário, que inquestionavelmente exercem posse, mas sem a intenção de ser dono. Neste ponto é que a teoria subjetiva foi superada pela teoria de Ihering, que defende ser o elemento anímico parte integrante do corpus, o que permite conceber a posse nas situações mencionadas.

No Brasil, após a independência em 1822, a lei de 20 de outubro de 1823 dispôs que deveriam continuar em vigor as Ordenações e demais leis promulgadas em Portugal. Em 1858, sobreveio a Consolidação das Leis Civis, que manteve os princípios da posse herdados do direito português, dentre os quais estava a regulamentação dos interditos possessórios e a prescrição aquisitiva, bem como a exceção de domínio. Em seguida, o Esboço de Teixeira de Freitas $^{34}$ trata da posse com nítida influência de Savigny, e conceitua, em seu artigo 3.709, que "haverá posse quando alguém, por si ou por outrem, se achar na possibilidade de exercer atos dominicais sobre alguma coisa com a intenção de ter direito de possuí-la”.

Os projetos de Nabuco Araújo e de Joaquim Felício dos Santos não trouxeram evolução sobre a matéria possessória. O primeiro, que não foi concluído em razão da morte de Nabuco Araújo, não fazia qualquer menção à posse, e o projeto de Felício manteve-se fiel à teoria subjetiva da posse. ${ }^{35}$

Em seguida, essa concepção da posse a partir das ideias de Savigny foi alterada substancialmente pelo projeto de Coelho Rodrigues, encomendado em 1890 e apresentado em 1893, no qual o autor refuta veementemente a teoria subjetiva. No entanto, o projeto não foi aprovado no ponto em que conceituava os possuidores como "todos que detêm em

\footnotetext{
34 Assim conhecido o resultado do trabalho de elaboração do seu Projeto de Código Civil, que não se completou por discordância do Governo de seguir a sugestão de Teixeira de Freitas de dividir o projeto em dois Códigos.

35 Art. 1.297: "Se diz possuidor, aquele que, com ânimo de proprietário, detém uma coisa ou exerce um direito, ou detenha a coisa, ou exerça o direito o direito por si ou por outrem em seu nome. Tal detenção da coisa ou exercício do direito se diz posse”.
} 
nome de outro, mesmo o detentor precário, desde que tem sobre a coisa um interesse legítimo”, tampouco ao classificar a posse como direito real. ${ }^{36}$

Posteriormente, o Código Civil de 1916, segundo afirmação de Washington de Barros Monteiro, ${ }^{37}$ foi o primeiro em que a teoria objetiva de Ihering foi sustentada, pois o Código alemão somente em parte a acolheu, tendo absorvido o corpus da doutrina de Savigny, e não o animus possidendi.

Nota-se, porém, que o Código Civil de 1916 não conceituou a posse, mas sim o possuidor, o titular do direito, pois dispunha que "considera-se possuidor todo aquele que tem, de fato, o exercício, pleno ou não, de algum dos poderes inerentes ao domínio ou propriedade”. Esse texto foi quase que integralmente reproduzido pelo Código Civil de 2002, tendo sido suprimida apenas a expressão “domínio”, por ser considerada aplicável somente aos bens corpóreos.

Parece-nos equivocado, entretanto, conceituar a posse a partir da propriedade, como se fosse dependente desse instituto que, como se viu, nasceu e se desenvolveu com base nos valores da posse. Ao conceituar a posse relacionando-a com a propriedade, o legislador depreciou o seu valor, desprezando o fato posse e concebendo-a apenas como direito, e desta forma identificou o possuidor como aquele que detém a propriedade.

Segundo Francisco Cardozo Oliveira, ${ }^{38}$ a desvalorização da posse em relação à propriedade teve início no Brasil com a Lei de Terras de 1850, que em seu artigo 1. ${ }^{\circ}$ dispôs que "ficam proibidas as aquisições de terras devolutas por outro título que não seja o de compra”. Portanto, teria a Lei de Terras consolidado a propriedade privada de grande extensão e restringido o reconhecimento do caráter fático da posse pelo sistema jurídico.

Não se identifica a posse a partir da propriedade, com abstração de seu conteúdo valorativo próprio. A posse "refere-se a uma vontade do indivíduo que deve ser respeitada pela necessidade mesma de todos de apropriação e exploração econômica das coisas, desde

\footnotetext{
36 MOREIRA ALVES, José Carlos. Posse. Evolução histórica, p. 350.

37 BARROS MONTEIRO, Washington de; MALUF, Carlos Alberto Dabus. Curso de direito civil. v. 3. Direito das coisas, p. 30.

38 OLIVEIRA, Francisco Cardozo. Hermenêutica e tutela da posse e da propriedade, p. 253.
} 
que esta vontade corresponda a um ideal coletivo, segundo os costumes e opinião pública”. 39

Apesar da alegada imperfeição da lei no tocante ao conceito de posse, Pontes de Miranda considerou que o conceito de posse previsto no Código Civil de 1916 “definiu a posse vendo-a do mundo jurídico, mas sabendo que ela está no mundo fático, que é apenas elemento fático que pode vir a entrar no mundo jurídico que a tome como um dos elementos ou em virtude de ato-fato ou, ainda, de fato jurídico puro”. ${ }^{40}$

Já Joel Dias Figueira Jr., ao interpretar o artigo 1.196 do Código Civil de 2002, conceitua a posse como "situação fática com carga potestativa que, em decorrência da relação socioeconômica formada entre um bem e o sujeito, produz efeitos que se refletem no mundo jurídico", destacando, ainda, que "seu primeiro e fundamental elemento é, portanto, o poder de fato, que importa na sujeição do bem à pessoa e no vínculo de senhoria estabelecido entre o titular e o bem respectivo". ${ }^{41}$

Enfim, tem-se ainda como predominante a conceituação da posse a partir do instituto da propriedade, como se apêndice desta realmente fosse - provável resquício da teoria de Ihering que, por sua força, ainda faz prevalecer a ideia de que a posse é mera exteriorização da propriedade. Entretanto, as teorias sociais da posse apresentaram-na de forma mais simples e lógica, conceituando-a a partir do fato da posse em si, que independe da propriedade para existir.

\subsection{Natureza jurídica}

Também vem desde o direito romano a polêmica acerca da natureza jurídica da posse, permanecendo vivo até hoje o debate sobre o tema. Não há consenso, tanto na doutrina como na jurisprudência, sobre ser a posse fato ou direito, e para quem a considera um direito, se é pessoal ou real, sendo relevante tal questão ainda hoje não apenas do ponto

\footnotetext{
39 ALBUQUERQUE, Ana Rita Vieira. Da função social da posse e sua consequência frente à situação proprietária, p. 128.

${ }^{40}$ PONTES DE MIRANDA, Francisco Cavalcanti. Tratado de direito privado, t. X, p. 8.

41 FIGUEIRA JR., Joel Dias; FIUZA, Ricardo. Código Civil comentado, p. 1108.
} 
de vista acadêmico e histórico, mas também em razão da sua repercussão no campo processual, sobretudo no tocante à legitimidade e à competência das ações possessórias.

Como visto, a posse não teve um tratamento idêntico em todas as fases do direito romano, o que se depreende da análise do Corpus Iuris Civilis, em que se encontra a posse como direito subjetivo, como fato e também direito e, ainda, a posse como fato, sem natureza de direito. Segundo Moreira Alves, as teses posse-fato e posse-direito "se harmonizam na perspectiva histórica: no direito romano clássico, a posse era o simples fato (res facti), mas, no direito justinianeu, deixou de sê-lo, aproximando-se de um direito, como pretende Kaser, ou, como sustenta Albertario, passando a ser considerada verdadeiro direito (o ius possessionis)", ${ }^{42}$

Surgiram, então, com o decorrer dos tempos, três teorias sobre a natureza da posse, sendo a primeira aquela que considera a posse um fato. Adepto dessa primeira teoria, Pontes de Miranda afirma que "a posse nada tem com o existir, ou não, o direito real, ou pessoal, a que pudesse corresponder". ${ }^{43}$ Igualmente, Octavio Guimarães sustenta que a posse "é um fato a que a lei atribui certas consequências jurídicas, como o direito à ação na posse genérica, aos frutos na posse titulada e ao usucapião nos casos apontados na lei”. ${ }^{44}$ Na mesma linha segue, ainda atualmente, Francisco Cardozo Oliveira, ao considerar que "a posse é poder fático que materializa a apropriação direta da coisa, embora seja relação entre pessoas e não entre pessoas e coisas”. ${ }^{4}$

Para Savigny, a posse é fato, se considerada em si mesma, mas é também direito, considerando os efeitos que produz. Portanto, posse seria ao mesmo tempo fato e direito, concepção da segunda corrente desenvolvida sobre o tema. Para chegar a tal conclusão, Savigny afirma que no direito romano a posse estava sempre relacionada à usucapião ou aos interditos, e que todos os princípios de direito relacionados à posesión tinham o único objetivo de determinar a viabilidade da usucapião ou dos interditos. Com isso, Savigny considera que a posse em si mesma não é mais do que um fato - que não se presta a cessão

\footnotetext{
42 MOREIRA ALVES, José Carlos. Posse. Evolução histórica, v. 2, p. 70.

43 PONTES DE MIRANDA, Francisco Cavalcanti. Tratado de direito privado, t. X, p. 73.

44 GUIMARÃES, Octávio. Da posse e seus efeitos, p. 24

45 OLIVEIRA, Francisco Cardozo. Hermenêutica e tutela da posse e da propriedade, p. 246.
} 
ou transferência -, mas admite que produz efeitos legais, e conclui que é ao mesmo tempo fato e direito. ${ }^{46}$

Compartilhavam desse entendimento Lafayette Rodrigues Pereira, para quem a “posse é um fato e um direito: - um fato pelo que respeita à detenção, um direito por seus efeitos”, 47 e Antônio Joaquim Ribas, segundo o qual "a posse, considerada em si mesma, é apenas um fato; mas, considerada em suas consequências, é um direito”. 48

Já Ihering, considerando que direito é o interesse juridicamente protegido, defende que a posse é direito. ${ }^{49}$ Para defender seu posicionamento, Ihering sustenta que qualquer direito é precedido por um fato gerador, ou seja, o direito de crédito é gerado por um contrato, o direito de sucessão pode ser gerado por um testamento, e o direito à situação possessória, à sua proteção, é gerado pelo nascimento da posse. Ihering afirma, com isso, que, "se a posse como tal não fosse protegida, não constituiria, na verdade, senão uma relação de puro fato sobre a coisa; mas, desde o momento em que é protegida, reveste o caráter de relação jurídica, o que vale tanto como um direito". ${ }^{50}$

Esclarece Ihering que as divergências acerca da natureza jurídica da posse decorrem da incompreensão de que, em todos os direitos, à exceção da posse, o direito se separa do fato gerador desde o momento que nasceu, a exemplo do contrato e do direito de crédito por ele gerado, e na posse, a manutenção do fato é condição do direito à sua proteção. Vale dizer: o direito nasce com a aquisição da posse e desaparece com a sua perda, não havendo um sem o outro.

46 “Hemos determinado la significación que tiene la posesión en derecho romano: toda posesión se refiere a la usucapión o a los interdictos y todos los principios de derecho relativos a la posesión considerada como en algún modo jurídica, no tienen más objeto que determinar la posibilidad de la usucapión o de los interdictos [...] la posesión en sí misma y según su naturaleza primitiva no es más que un hecho: es igualmente indudable que produce ciertos efectos legales. Es, pues, al mismo tiempo hecho y derecho [...] Así la posesión es al mismo tempo hecho y derecho. Sería tan inútil como poco instructivo reproducir todas las discusiones que se han suscitado entre los autores con motivo de esta cuestión” (SAVIGNY, M.F.C. de. Tratado de la posesión, p. 16 e 19).

47 PEREIRA, Lafayette Rodrigues. Direito das coisas. v. 1, p. 40.

48 RIBAS, Antônio Joaquim. Da posse e das ações possessórias, p. 8.

49 IHERING, Rudolf von. Teoria simplificada da posse, p. 42.

50 Idem, ibidem, p. 41. 
Seguiram o entendimento de Ihering, entre outros, Teixeira de Freitas, Astolpho Rezende $^{51}$ e Edmundo Lins, e, para este último, "é incontestável que a posse é um direito real”. 52

Apesar do aparente antagonismo das teorias, pode-se afirmar que, na essência, divergência quase não há. Senão, basta constatar que os autores que defendem ser a posse um mero fato não negam a produção de efeitos jurídicos, e os que sustentam ser um direito também não refutam a sua origem a partir de um fato. Parece-nos que as controvérsias decorrem de uma peculiaridade da posse: diferente do que ocorre com os direitos subjetivos em geral - como o direito de crédito oriundo de contrato -, que perduram ainda que o fato que lhe deu origem tenha cessado, a posse mantém-se sempre unida ao seu fato gerador.

É elucidativa, nesse sentido, a explicação de Ihering de que, "na maioria dos direitos, a confusão do fato gerador com o próprio direito é excluída pela diversidade mesma dos nomes que a linguagem lhes dá; por exemplo, o contrato e o crédito, o testamento e o direito sucessório [...] a posse, como estado de fato, ${ }^{53}$ liga-se e refere-se à posse como direito" ${ }^{54}$ No caso da posse, portanto, dá-se o mesmo nome ao fato gerador e ao direito - indissociáveis -, e daí decorre a interminável divergência que, na verdade, não passa de confusão.

E por isso, quando se trata de posse, sempre haverá fato e direito; a posse não é exclusivamente direito, mas também é mero fato. Assim, parece-nos que a teoria que melhor explica a posse é aquela que sustenta ser fato e direito não nos moldes como defendeu Savigny - mero fato que gera consequências jurídicas e por isso é direito -, pois se mostra mais adequado afirmar que recebem o nome "posse” tanto o fato gerador como o seu respectivo direito. Ou seja, não se trata de uma só coisa com duas qualidades (posse é

\footnotetext{
51 “A terceira escola sustenta o caráter jurídico da posse; à frente desse grupo está Ihering, seguindo de muitos outros [...] Acertada parece-nos, pois, a terceira teoria” (REZENDE, Astolpho. A posse e sua proteç̧ão, v. 1, p. 280-282).

52 LINS, Edmundo. Ensaio sobre a posse. Revista da Faculdade Livre de Direito do Estado de Minas Gerais, v. 9, p. 248, 1914.

53 Fala-se em "estado de fato" porque o fato gerador do direito, no caso da posse, é duradouro, só existindo o direto (a posse) enquanto perdura o fato.

${ }^{54}$ IHERING, Rudolf von. Teoria simplificada da posse, p. 42.
} 
fato e é direito), mas sim de duas coisas distintas (fato gerador e direito) com o mesmo nome: posse.

Logo, considerando que a identificação da natureza jurídica de um instituto importa em determinar a qual categoria jurídica pertence, e que esse enquadramento depende da identificação das características do instituto com a respectiva categoria, resta indubitável que a posse não é só fato, visto que o mero fato não gera consequências jurídicas e não pode ser transmitido. ${ }^{55}$

A pertinência prática da discussão sobre ser a posse um fato ou um direito importa justamente em saber se é possível ou não a sua cessão ou transferência, pois somente um direito poderia ser transmitido. No entanto, o advento dos artigos 496 e 497 do Código Civil de 1916, reproduzidos com a mesma redação pelos artigos 1.206 e 1.207 do Código Civil de 2002, pôs fim à discussão - ou ao menos à sua utilidade prática -, porquanto admitiu expressamente a transmissibilidade da posse. Não é incomum, todavia, encontrar na jurisprudência afirmações de que a posse é fato e que, por isso, não pode ser transmitida ou cedida. ${ }^{56}$

No tocante à colocação da posse no quadro geral das matérias de direito civil, para classificá-la como direito pessoal ou real, também não há consenso na doutrina. Astolpho Rezende afirma que “os glosadores consideravam-na direito real, e reais as ações dela nascidas", e que "muitos autores, posteriores e modernos, adotaram a mesma classificação". 57

55 “[...] dois elementos compõem a situação de direito [...] O primeiro é um elemento material, um simples fato; o segundo é um elemento formal, que se apodera do fato e lhe confere forma jurídica: 'mas, nem todas as relações entre os homens incidem no domínio do direito: nem todas podem ou precisam ser determinadas por uma regra desta natureza. E, aqui, cabe distinguir três casos: ora a relação é inteiramente dominada pela regra de direito, ora o é em parte, ora ao domínio desta regra escapa totalmente. A propriedade, o casamento e a amizade podem ser citados como exemplos desses três casos" (RÁO, Vicente. O direito e a vida dos direitos, v. 2, p. 715).

56 “Ora, posse é fato e, assim, somente em casos expressos em lei, pode ser transmitida por meio de contrato ou fato, como, por exemplo, a morte (art. 1572 do Cód. Civil), hipóteses que não albergam o caso analisado" (Apelação 588750-1, 1. ${ }^{a}$ Câmara de Direito Privado do extinto Primeiro TAC-SP, Rel. Juiz Edson Jorge, DJ 23.02.1995). Apenas um acórdão de 1995 é insuficiente para sustentar o argumento.

57 REZENDE, Astolpho. A posse e sua protecção, v. 1, p. 282. 
Savigny e Ihering também divergem sobre essa questão, visto que o primeiro defende o caráter pessoal da posse, enquanto o segundo entende que se trata de direito real.

Lafayette ensina que “direito real é o que afeta a coisa direta e imediatamente, sob todos ou sob certos respeitos, e a segue em poder de quem quer que a detenha". ${ }^{58}$ Nas palavras de Flávio Tartuce e José Fernando Simão, os direitos reais são “as relações jurídicas estabelecidas entre pessoas e coisas determinadas ou determináveis, tendo como fundamento principal o conceito de propriedade, seja ela plena ou restrita". 59 Sílvio de Salvo Venosa estabelece a diferença entre direito pessoal e real afirmando que "o direito pessoal une dois ou mais sujeitos, enquanto os direitos reais traduzem relação jurídica entre uma coisa, ou conjunto de coisas, e um ou mais sujeitos, pessoas naturais ou jurídicas”. ${ }^{60}$

A doutrina elenca inúmeras características dos direitos reais que os diferenciam dos direitos pessoais, destacando-se entre elas (1) a oponibilidade erga omnes do direito sobre da coisa, que no direito pessoal é oponível apenas a um sujeito passivo; (2) o objeto do direito real, que, ao contrário do objeto (determinável) do direito pessoal, é sempre determinado, vale dizer; (3) a atualidade da coisa, diversamente da futuridade compatível com o ius ad persona; (4) o direito de sequela, que autoriza o titular do direito real a retirar a coisa do poder daquele que o viola; (5) a preferência, que "consiste no privilégio do titular de direito real em obter o pagamento de um débito com o valor do bem aplicado exclusivamente à sua satisfação"; ${ }^{61}$ (6) a taxatividade, ou princípio do numerus clausus, segundo o qual a criação de direitos reais depende de reserva legislativa, estando os direitos reais enumerados no artigo 1.225 do Código Civil; (7) a suscetibilidade de posse dos direitos reais; e (8) o princípio da publicidade, que se impõe aos direitos reais para dar conhecimento a terceiros.

A partir dessas características atribuídas aos direitos reais e que não estão presentes nos direitos pessoais, alguns autores sustentam que nessa categoria de direito se insere a posse, porquanto seria possível identificar nela algumas das referidas

\footnotetext{
58 PEREIRA, Lafayette Rodrigues. Direito das coisas. v. 1, p. 21.

59 TARTUCE, Flávio; SIMÃO, José Fernando. Direito das coisas, p. 4.

60 VENOSA, Sílvio de Salvo. Direito civil. v. 5. Direitos reais, p. 4.

61 ROSENVALD, Nelson; FARIAS, Cristiano Chaves de. Direitos reais, p. 8.
} 
características. Segue esse entendimento Caio Mário, para quem a posse, “sem embargo de opiniões em contrário, é um direito real, com todas as suas características; oponibilidade erga omnes, indeterminação do sujeito passivo, incidência em objeto obrigatoriamente determinado etc.”. 62

Não é diverso o entendimento de Orlando Gomes, segundo o qual, "na posse, a sujeição da coisa à pessoa é direta e imediata". ${ }^{63}$ Pontes de Miranda sustenta que "a situação possessória, já no mundo fático, é real”, e que, “ao entrar no mundo jurídico, é real (senso largo) o direito, e reais são as pretensões e as ações”. ${ }^{64}$ Arnaldo Rizzardo sustenta a natureza real da posse e das ações possessórias porquanto, na sujeição da coisa à pessoa de forma direta e imediata, não existe um sujeito passivo, exercendo-se erga omnes, portanto, o direito do possuidor, virtude ínsita aos direitos reais. ${ }^{65}$ Também caracterizam a posse como direito real Carlos Alberto Bittar, ${ }^{66}$ Orlando Gomes ${ }^{67}$ e Maria Helena Diniz.

No entanto, embora seja aparentemente possível identificar na posse algumas das características dos direitos reais, a análise mais cuidadosa demonstra que tais não se amoldam perfeitamente à situação do possuidor. O efeito erga omnes, por exemplo, que a maioria dos doutrinadores que sustenta a natureza real da posse lhe atribui, não se apresenta de forma plena na posse, pois, dependendo da situação fática, o possuidor pode

62 PEREIRA, Caio Mário da Silva. Instituições de direito civil. v. 4. Direitos reais, p. 22.

63 “Não há um sujeito passivo determinado. O direito do possuidor se exerce erga omnes. Todos são obrigados a respeitá-lo. Só os direitos reais têm essa virtude. Verdade é que os interditos se apresentam com certas qualidades de ação pessoal, mas nem por isso influem sobre a natureza real do jus possessionis. Destinados à defesa de um direito real, hão de ser qualificados como ações reais, ainda que de tipo sui generis" (GOMES, Orlando. Direitos reais, p. 28).

64 PONTES DE MIRANDA, Francisco Cavalcanti. Tratado de direito privado, t. X, p. 73.

65 "Há aqueles que defendem a natureza real na sujeição da coisa à pessoa de forma direta e imediata. Não existe um sujeito passivo determinado. Exerce-se erga omnes o direito do possuidor, todas as pessoas sendo obrigadas a respeitá-lo. Essa irradiação que leva ao respeito universal constitui uma virtude ínsita aos direitos reais. Os interditos decorrem de tal virtude, embora contenham certas qualidades de ação pessoal, que não influem sobre a natureza real do jus possessionis. Todavia, destinando-se à defesa de um direito real, levam à sua qualificação como ações reais, embora a particularidade da pessoalidade" (RIZZARDO, Arnaldo. Direito das coisas, p. 29).

66 "Desse modo, revestida dos caracteres próprios à espécie, a posse é direito real, mostrando-se, como os demais, oponível erga omnes, e incidindo sobre objeto determinado, material ou imaterial, conforme o caso” (BITTAR, Carlos Alberto. Direitos reais, p. 33).

67 "Se ela é, como visto, um direito real, outra não pode ser a sua localização. A caracterização da posse como direito real ou, mesmo, como direito sui generis, pode ser pensada como ponto de partida para a evolução doutrinária que afirma a autonomização da posse frente à propriedade” (GOMES, Orlando. Direitos reais, p. 41). 
sucumbir diante de alguém com melhor posse, ou mesmo diante do proprietário. Ademais, muito embora seja possível atribuir com limitação esta característica à posse, é essencial para a configuração dos direitos reais a previsão legal, visto que somente o legislador pode criá-los.

Atento a esse aspecto, Nelson Nery Junior assevera que a ação possessória não é real porque tem como causa de pedir a proteção da posse, "que não se encontra no rol taxativo dos direitos reais no direito positivo brasileiro" ${ }^{68}$ Igualmente indispensável à caracterização de um direito real é a sequela, direito que indiscutivelmente não socorre o mero possuidor. Ou seja, "se a posse fosse verdadeiramente um direito real, a sequela seria plena, atingindo até mesmo o terceiro de boa-fé, como ocorre na propriedade (art. 1.247, parágrafo único, do CC)”, 69

Savigny defende que "a posse pertence ao direito das obrigações”, e que "o direito aos interditos possessórios pertence às obrigações”. ${ }^{70}$ Também entendem que a posse não é um direito real Eduardo Espínola ${ }^{71}$ e Silvio Rodrigues, para quem "não se pode considerar a posse direito real porque ela não figura na enumeração do art. 1.225 do Código Civil”. ${ }^{72}$ Adotam posição intermediária Cristiano Chaves de Farias e Nelson Rosenvald, ${ }^{73}$ Gustavo

68 NERY JUNIOR, Nelson; NERY, Rosa Maria de Andrade. Código de Processo Civil comentado, p. 244.

${ }^{69}$ ROSENVALD, Nelson; FARIAS, Cristiano Chaves de. Direitos reais, p. 33.

70 “[...] la posesión pertenece al derecho de las obligaciones [...] El derecho de los interdictos posesorios pertenece a las obligaciones por la sola razón de que generalmente todos los interdictos forman parte de ellas” (SAVIGNY, M.F.C. de. Tratado de la posesión, p. 19).

${ }^{71}$ ESPÍNOLA, Eduardo. Posse - Propriedade. Compropriedade ou condomínio. Direitos autorais. Conquista, p. 18.

72 “[...] como vimos, aquela regra é taxativa, não exemplificativa, tratando-se, ali, de numerus clausus. Esse é o meu ponto de vista” (RODRIGUES, Silvio. Direito civil. v. 5. Direito das coisas, 28. ed., p. 21).

73 "Ademais, na concepção objetivista, sendo a posse considerada como a visibilidade (aparência) da propriedade - o mais amplo dos direitos reais -, não restaria outra opção a não ser dotar a posse de natureza real. Seria uma espécie de relação entre acessório (posse) e principal (propriedade), pois não haveria propriedade sem posse [...] quando o proprietário é o possuidor de seu próprio bem. Aqui a posse é vista como um direito real, na visão restrita do art. 1.196, do Código Civil [...] pode também a posse ser vislumbrada como relação obrigacional, quando emanada, exemplificadamente, de um contrato de locação, promessa de compra e venda ou comodato, na qual o objeto é a coisa, jamais o direito em si (ROSENVALD, Nelson; FARIAS, Cristiano Chaves de. Direitos reais, p. 33). 
Tepedino, ${ }^{74}$ Flávio Tartuce ${ }^{75}$ e o italiano Roberto de Ruggiero, ${ }^{76}$ no sentido de que a posse seria um direito sui generis, com características de direito pessoal e de direito real.

Ao fazer referência à afirmação de Caio Mário de que a indeterminação do sujeito passivo na posse a elevaria à categoria de direito real, Cláudia Aparecida Cimardi sustenta, acertadamente, que “essa circunstância, por si só, não é suficiente para caracterizar a posse como um direito real”. ${ }^{77}$

Da classificação da posse como direito real ou pessoal depende a classificação das ações possessórias como pessoais ou reais - tema que será abordado com maior profundidade adiante (item 4.6), e daí a necessidade ou não de se estabelecer o litisconsórcio necessário entre os cônjuges, bem como de definir a competência, que, apesar da polêmica, já está expressamente determinada no artigo 95 do Código de Processo Civil.

\subsection{Posse e detenção}

Não menos problemática é a distinção entre possuidor e detentor, visto que, no tocante aos atos exteriorizados por um e por outro, pouca ou nenhuma diferença há entre as situações de ambos, pelo que se compartilha da afirmação de que "problema fundamental em matéria de posse tem sido o da distinção entre esta e a detenção”. ${ }^{78}$

José Carlos Moreira Alves nos dá conta de que a distinção entre posse e detenção ainda não existia no tempo de Cícero, período clássico do direito romano, sendo prova

\footnotetext{
74 "Tais circunstâncias conferem à posse posição autônoma e sui generis, com aspectos de pessoalidade e aspectos de realidade” (TEPEDINO, Gustavo. Comentários ao Código Civil. v. 14. Direito das coisas, p. 49)

75 “[...] a posse é um conceito intermediário, entre os direitos pessoais e os direitos reais” (Direito civil. v. 4. Direito das coisas, p. 28).

76 "Mas de que natureza seja esse direito, volta discutir-se pois, ao passo que alguns lhe atribuem caráter real, sendo exercível erga omnes, outros consideram-no pessoal, porque na tutela da posse é o direito de personalidade que se protege; e outros finalmente classificam-no como um direito real sui generis" (RUGGIERO, Roberto de. Instituições de direito civil. v. 2. Direitos de família. Direitos reais e posse, p. 620).

77 CIMARDI, Cláudia Aparecida. Proteção processual da posse, p. 20.

${ }^{78}$ MOREIRA ALVES, José Carlos. A detenção no direito civil brasileiro. In: CAHALI, Yussef Said (Coord.). Posse e propriedade, p.1.
} 
disso a crítica feita por Paulo a Quinto Múcio no Digesto (41, 2, 3, 23), ${ }^{79}$ e que Pégaso, jurisconsulto da época de Vespasiano, teria sido o mais antigo jurista a distinguir detenção de posse ${ }^{80}$ Segundo o mesmo autor, no período republicano distinguia-se o possuidor em nome próprio do que exercia a posse em nome alheio (próprio nomine e alieno nomine), e somente com Labeão é que teria sido apresentado o animus como elemento constitutivo da posse, o que passou a diferenciá-la da detenção. A partir daí, desenvolve-se a ideia da detenção com a expressão possessio naturalis, caracterizada pelo elemento material da posse e, por isso, vista como simples fato material, não suscetível de proteção jurídica.

Ao explicar a possessio romana, Roberto de Ruggiero ensina que, “quando à relação física e material com a coisa não se junta uma intenção correspondente de se assenhorar dela, não se tem senão uma mera detenção, uma naturalis possessio, improdutiva ou quase improdutiva de efeitos jurídicos, não se tem posse”. ${ }^{81}$

No direito canônico, ao contrário do direito romano, admitiu-se a proteção jurídica da simples detenção. A situação decorrente da deficiência da autoridade do Estado e do impulso da Igreja na Idade Média propiciou a dispensa de amparo, pela Igreja, contra a violência praticada aos detentores, que o Estado deixava sem proteção, "principalmente quanto aos ofícios e dignidades religiosas”. 82

As teorias subjetiva e objetiva da posse, desenvolvidas por Savigny e Ihering, respectivamente, apresentaram divergências também na conceituação da detenção em relação à situação do possuidor, ou seja, na distinção entre ambos os institutos.

79 “Eu não concordo com o modo de ver de Quinto Múcio, quando coloca entre as espécies de posse aquela na qual o juiz envia aquele que tem interesse em conservar a cousa, ou aquele a quem se recusa de dar caução em virtude de um perigo iminente; porque, nestes dois casos, tanto como naquele em que o juiz envia um indivíduo em posse, em nome de uma crença por nascer, não se tem a posse, mas somente a guarda e a conservação das cousas” (Digesto, Livro 41, II, 3, § 23. Tradução: MERÉJE, Rodrigues de. Teorias jurídicas da posse, p. 22).

80 MOREIRA ALVES, José Carlos. A detenção no direito civil brasileiro. In: CAHALI, Yussef Said (Coord.). Posse e propriedade, p. 23.

81 RUGGIERO, Roberto de. Instituições de direito civil. v. 2. Direitos de família. Direitos reais e posse, p. 601.

82 ESPÍNOLA, Eduardo. Posse - Propriedade. Compropriedade ou condomínio. Direitos autorais. Conquista, p. 42. 
Para Savingy, que identificava na posse os dois elementos - corpus e animus domini -, a detenção era representada apenas pelo corpus, pelo poder físico sobre a coisa, sem a intenção de ser dono. Assim, na concepção da teoria subjetivista, seria detentor, e não possuidor, aquele que exerce o poder físico sobre a coisa sem pretensão de ser dono. Com isso, a detenção seria a posse sem o animus domini. ${ }^{83}$

Já a teoria objetiva explica a detenção a partir da lei, visto que, nessa concepção, a detenção é a posse reduzida por uma disposição legal. Portanto, Ihering entende que, quando há um comportamento similar de proprietário em relação a coisa, tem-se presente a posse, e essa situação de fato não é reduzida à detenção em decorrência do elemento volitivo, mas sim por decorrência de uma previsão legal.

Assim, Ihering defende que tanto na posse quanto na detenção existe a situação material, denominada corpus, e a consciência ou voluntariedade de ter a coisa consigo, a vontade de deter a coisa (affectio tenendi), mas na detenção há uma causa que decorre de determinação legal e que reduz a posse à detenção.

Para Ihering, portanto, a posse se configura com o corpus, que está indissociavelmente ligado ao affectio tenendi. ${ }^{84}$ A detenção, no seu entendimento, compunha-se igualmente do corpus e desse elemento anímico, mas era assim classificada em razão da determinação legal, que desqualifica a posse para detenção. Para explicar essa distinção, a doutrina cultora da teoria objetiva se vale de fórmulas algébricas, que a seguir se transcrevem:

$$
\text { Posse }=\text { corpus }+ \text { affectio tenendi }
$$

Detenção $=$ corpus + affectio tenendi - dispositivo legal

Para representar o entendimento de Savigny, a fórmula seria a seguinte:

83 "En efecto, cualquiera detentación para poderse modificar en posesión, debe ejercerse con intención, esto es, que para ser poseedor es preciso no sólo que haya retención, sino también voluntad de que la haya” (SAVIGNY, M.F.C. de. Tratado de la posesión, p. 66).

84 IHERING, Rudolf von. O fundamento dos interdictos possessorios, p. 313. 
Posse $=$ corpus + affectio tenendi + animus domini

\section{Detenção $=$ corpus + affectio tenendi}

O ordenamento jurídico brasileiro encampou, desde o Código Civil de 1916, a teoria objetiva também no tocante ao tratamento da detenção, de modo a considerar possuidor "aquele que exerce para si, no seu interesse, sobre uma coisa, algum ou alguns dos poderes inerentes ao domínio; não é possuidor o que detém a coisa para outrem, no proveito ou interesse deste". 85

O Código Civil de 1916 previa quatro hipóteses de detenção, presentes nos revogados artigos 487, 497, 520, inciso III, e 522. À exceção do artigo 520, inciso III, tais dispositivos foram praticamente reproduzidos pelo nosso direito positivo vigente, nos artigos 1.198 e 1.208 do atual Código Civil.

Prevê o artigo 1.198 do Código Civil de 2002: “considera-se detentor aquele que, achando-se em relação de dependência para com outro, conserva a posse em nome deste e em cumprimento de ordens e instruções suas”. O dispositivo trata da situação do fâmulo da posse, também denominado servidor da posse, que tem na situação fática para com a coisa uma relação de subordinação e dependência com o possuidor, de quem recebe ordens e orientações, estando vinculado o exercício do seu poder sobre a coisa a essa subordinação. Assim, o detentor "possui relação com a coisa em nome do dono ou do verdadeiro possuidor”. ${ }^{86}$ Tal circunstância, que se verifica, por exemplo, na relação entre o caseiro e o imóvel deixado sob os seus cuidados na ausência do patrão, desqualifica a posse para detenção, em decorrência da previsão legal expressa ${ }^{87}$.

Sendo assim, o detentor que se enquadra na norma do referido dispositivo legal não exerce posse própria sobre a coisa, mas sim em nome do verdadeiro possuidor, e por isso não pode se valer dos interditos. Sustenta-se, entretanto, que poderia o detentor nessas

85 REZENDE, Astolpho. A posse e sua protecção. v. 1, p. 228.

86 VENOSA, Sílvio de Salvo. Direito civil. v. 5. Direitos reais, p. 42.

87 “Indenização. Sentença que julgou improcedentes os pedidos de indenização por benfeitorias e indenização por perda de uma chance. Caseiro do imóvel. Mera detenção não autoriza a aquisição de posse (CC, art. 1.208)” (TJSP, Apelação 0004680-92.2009.8.26.0299, Rel. Milton Carvalho, 4. ${ }^{\text {a }}$ Câmara de Direito Privado, DJ 08.11.2012). 
condições defender a posse alheia por meio da autotutela, regulamentada pelo artigo 1.210, $\S 1 .^{\circ}$, do Código Civil. ${ }^{8}$

A norma do parágrafo único do artigo 1.198 do Código Civil criou a presunção relativa - não prevista no Código Civil de 1916 - de continuidade da detenção para aquele que inicia seu comportamento em relação de dependência para com outro. Dispõe o referido artigo que "aquele que começou a comportar-se do modo como prescreve este artigo, em relação ao bem e à outra pessoa, presume-se detentor, até que prove o contrário”.

É certo que a detenção pode se transformar em posse, caso o detentor deixe de agir em nome alheio e passe a exercer o poder sobre a coisa em nome próprio, não mais por subordinação ao possuidor. Ocorre que, por força da presunção legal criada pelo legislador do Código Civil de 2002, favorece o possuidor a presunção de continuidade da detenção, e assim, caso o detentor queira ver reconhecida a usucapião em seu favor, terá como obstáculo a presunção relativa de que é mero detentor, devendo, portanto, comprovar a transformação da situação originária em posse.

Não basta, entretanto,

[...] a simples alegação de inversão do animus por parte do detentor, que pretende demonstrar que possui em nome próprio, não lhe sendo dado alterar, por sua exclusiva vontade - condição puramente potestativa -, a índole da apreensão, a transformar, assim, a detenção em posse [...] somente atos objetivos e exteriores, em oposição ao direito do antigo possuidor, caracterizarão a conversão do título de aproveitamento da coisa $^{89}$

Também é considerado detentor aquele que, por tolerância ou permissão do possuidor, exerce poderes sobre a coisa. Nesse sentido, dispõe a primeira parte do artigo 1.208 do atual Código Civil que "não induzem posse os atos de mera permissão ou tolerância”.

${ }^{88}$ Enunciado 493 da V Jornada de Direito Civil: "O detentor (art. 1.198 do Código Civil) pode, no interesse do possuidor, exercer a autodefesa do bem sob seu poder".

89 TEPEDINO, Gustavo. Comentários ao Código Civil. v. 14. Direito das coisas, p. 85. 
A permissão se configura com um ato positivo do possuidor, "que, sem perda do controle e da vigilância sobre a coisa, entrega-a voluntariamente a terceiro, para que este a tenha momentaneamente". 90 Trata-se mera liberalidade do possuidor de deixar a coisa com terceiro, sem que isso possa caracterizar a perda da sua posse; diferente do caso do fâmulo da posse, o detentor, na hipótese de permissão, toma a coisa para si, usando-a em seu benefício, e não necessariamente desempenhando o papel de guarda e agindo em obediência às ordens do possuidor. Afirma Moreira Alves que, "nessa detenção, o interesse dela é exclusivamente do detentor, o que não ocorre na servidão da posse, onde, ainda que indiretamente, há o interesse do possuidor". 91

Imagine-se que o possuidor autorize o vizinho a utilizar parte de seu terreno para guardar material de construção, pelo tempo que perdurar a reforma de sua casa. Neste caso, não há transferência de posse, tampouco comodato; o possuidor simplesmente autorizou que o terceiro fizesse uso da coisa. A doutrina cita como exemplo, também, a situação de alguém que recebe uma visita em sua casa e lhe destina, por curto período, um quarto.

A permissão, segundo Moreira Alves,

[...] é a declaração de vontade do possuidor pela qual este, sem renunciar à posse nem fazer nascer para si qualquer obrigação que anteriormente não existia, confere a terceiro - o detentor - a faculdade de realizar, com relação à coisa, atos que, sem isso, seriam ilícitos. ${ }^{92}$

Tem-se, portanto, que a permissão se refere a atos futuros, enquanto a tolerância remete-se a uma conduta já ocorrida ou em andamento. Isso porque a tolerância é um comportamento de omissão do possuidor, podendo inclusive ser inconsciente; também sem representar renúncia à posse, por meio da tolerância o possuidor aceita a conduta de terceiro em relação à coisa, não a combatendo. Afirma Francisco Eduardo Loureiro que,

90 LOUREIRO, Francisco Eduardo. In: PELUSO, Cezar (Coord.). Código Civil comentado, p. 1165.

${ }^{91}$ MOREIRA ALVES, José Carlos. A detenção no direito civil brasileiro. In: CAHALI, Yussef Said (Coord.). Posse e propriedade, p. 18.

${ }_{92}$ Idem, ibidem, p. 17. 
"sendo uma mera indulgência, uma simples condescendência, não implica transferência de direitos". 93

A detenção decorrente tanto da permissão como da tolerância do possuidor acarreta certa limitação ao exercício de sua posse, visto que a coisa ou parte dela se sujeita ao poder do detentor. Entretanto, cabe ao possuidor, a qualquer momento, pôr fim à situação que permitiu ou tolerou, sem que, para tanto, seja necessária a prática de atos formais, como a notificação do detentor para interromper formalmente aquela situação ${ }^{94}$.

Além da detenção do fâmulo da posse e daquele que exerce poder sobre a coisa em decorrência de mera permissão ou tolerância do possuidor, o Código Civil regulamenta, na segunda parte do artigo 1.208, a detenção denominada independente, que tem origem sem que se configure qualquer relação de dependência com o possuidor. Consta do referido dispositivo legal, em relação à posse, “que não autorizam a sua aquisição os atos violentos, ou clandestinos, senão depois de cessar a violência ou a clandestinidade”.

Haverá detenção nessa situação, de acordo com a lei, enquanto perdurar a violência ou a clandestinidade, visto que a cessação desses vícios - que serão analisados detidamente no item 2.5.1 - acarreta a aquisição da posse injusta. Na vigência da violência ou da clandestinidade, portanto, não poderá o detentor se valer dos interditos, mas sendo tais vícios temporários, a aquisição da posse ocorrerá tão logo estes desapareçam, sendo possível, então, o manejo das ações possessórias contra terceiros que ameaçarem a posse injusta.

Também se configura a detenção quando o esbulho é praticado na ausência do possuidor, situação que perdura até o momento em que o esbulhado toma conhecimento da ofensa à sua posse e nada faz para retomar a coisa ou é repelido com violência ao tentar. É o que dispõe o artigo 1.224 do Código Civil (art. 522, CC/1916): “só se considera perdida

\footnotetext{
93 LOUREIRO, Francisco Eduardo. In: PELUSO, Cezar (Coord.). Código Civil comentado, p. 1166.

94 “POSSESSÓRIA - Reintegração de posse - Ocupação da área a título precário Empregados que ocuparam o local com a permissão dos proprietários - Posse precária que não autoriza a proteção possessória ou mesmo a prescrição aquisitiva - Ação procedente para reintegrar o autor na posse definitiva do imóvel Sentença mantida - RECURSO DESPROVIDO” (TJSP, Apelação 0004280-44.2004.8.26.0270, Rel. Moreira Veigas, $5^{a}$ Câmara de Direito Privado, Dj.: 13.12.12).
} 
a posse para quem não presenciou o esbulho, quando, tendo notícia dele, se abstém de retornar a coisa, ou, tentando recuperá-la, é violentamente repelido”.

Em outras palavras, a lei regulamenta que não induz posse o exercício do poder sobre a coisa por aquele que adquire a posse e a mantém por meio de atos clandestinos, ocultos, não ao menos até que cessem tais atos. Nessas condições, aquele que se investe contra a posse de outrem na sua ausência terá a mera detenção, ${ }^{95}$ que só se transformará em posse injusta quando cessar a ocultação dos atos em relação ao possuidor.

No tocante ao artigo 520, inciso II, do Código Civil de 1916 ("perde-se a posse das coisas [...] por serem postas fora do comércio”), que foi revogado e não encontra previsão correspondente no atual código, a doutrina e a jurisprudência ${ }^{96}$ são pacíficas em admitir que os bens públicos são insuscetíveis de posse, sendo que o poder eventualmente exercido pelo particular sobre coisa pública, não havendo autorização, será considerado mera detenção, e não posse.

Apesar de o Código Civil de 2002 não ter reproduzido a norma relativa às “coisas postas fora do comércio”, é certo que o ordenamento jurídico brasileiro continuou a regulamentar essa impossibilidade de exercício de posse pelo particular sobre bens públicos, sem autorização ou concessão do Poder Público, porquanto a Constituição

95 "Até que tenha ele notícia da ocupação e se abstenha de retomar a coisa ou seja repelido ao tentar recuperá-la, o ocupante é mero detentor” (MOREIRA ALVES, José Carlos. A detenção no direito civil brasileiro. In: CAHALI, Yussef Said (Coord.). Posse e propriedade, p.17).

96 A propósito, confirmam-se os seguintes julgados: “Como a detenção é posse degradada, juridicamente desqualificada pelo ordenamento jurídico, o pleito mostra-se descabido, pois a autora, como incontroverso nos autos, era invasora da área pública, por isso não há falar em composse ou direitos reais

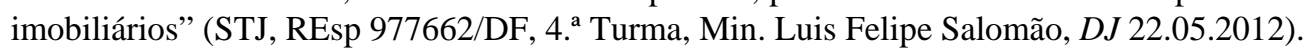

“Apelações cíveis. Ocupação de bem público. Reintegração na posse. 1. Ocupação de bem público. Esbulho caracterizado. Ocupação de bem público que não caracteriza posse, mas mera detenção. Bens públicos insuscetíveis de afetação particular, dada a sua destinação pública, não podendo ser objeto de usucapião, penhora ou alienação. Bens públicos que estão fora do comércio de direito privado, não estando sujeitos à posse ou a direitos à ela inerentes, inclusive o direito de retenção pelo ressarcimento de benfeitorias realizadas pelos ocupantes Ocupação meramente precária, sem garantia de permanência Precedentes do E. STJ e deste C. Tribunal de Justiça Paulista. Possessória procedente.Manutenção da sentença. 2. Recursos não providos” (TJSP, Apelação 0039634-11.2003.8.26.0224, 12. ' Câmara de Direito Privado, Rel. Des. Osvaldo de Oliveira, DJ 24.10.2012). 
Federal, "ao vedar expressamente a aquisição da propriedade de bens públicos pela usucapião, estaria criando um óbice ao seu exercício da posse”. ${ }^{97}$

Pode o Poder Público, porém, outorgar a utilização do bem público por meio de autorização, permissão ou concessão de uso, e nestas hipóteses evidentemente haverá posse, e não detenção, sendo admissível a utilização dos interditos contra terceiros e, inclusive, contra o próprio Poder Público, “caso a revogação ao ato concessivo se mostrar ilegítima ou ilegal”. 98

Por derradeiro, importa distinguir a detenção da simples "tença”, assim conceituada por Luciano de Camargo Penteado "a mera situação material de apreensão física do bem, sem qualquer consequência jurídica protetiva”. ${ }^{99}$ Refere-se o autor à situação daquele que, sem intenção, e até sem consciência, tem consigo a coisa, configurando uma mera "justaposição material entre pessoa e coisa”, ${ }^{100}$ que também como a detenção não recebe proteção processual em favor próprio.

\subsection{Classificação da posse}

A doutrina classifica a posse com o objetivo de identificar as suas diferentes espécies e consequências jurídicas, ${ }^{101}$ levando em conta as disposições legais que tratam dos elementos subjetivos e objetivos que influenciam na situação de fato do possuidor.

Como bem registrado por Orlando Gomes, “a posse existe como um todo unitário incindível”. ${ }^{102}$ No entanto, destaca o mesmo autor que “a presença, ou a ausência, de certos elementos, objetivos ou subjetivos, determina a especialização de qualidades, que a diversificam em várias espécies”.

\footnotetext{
97 ARAÚJO, Bárbara Almeida de. A posse dos bens públicos, p. 106.

98 CIMARDI, Cláudia Aparecida. Proteção processual da posse, p. 38.

99 PENTEADO, Luciano de Camargo. Direito das coisas, p. 471.

100 CIMARDI, Cláudia Aparecida. Proteção processual da posse, p. 41.

101 “Classificar a posse significa destacar as suas várias formas, com o objetivo de chegar àquelas manifestações que merecem a tutela jurídica” (RIZZARDO, Arnaldo. Direito das coisas, p. 41).

102 GOMES, Orlando. Direitos reais, p. 47.
} 
A classificação da posse, nesse sentido, não é tarefa meramente acadêmica e teórica, dado que, não tendo o exercício da posse sempre as mesmas características, as variantes que se apresentam nos casos concretos acarretam consequências jurídicas diversas, levando-se em conta o modo de aquisição e a consciência do possuidor em relação ao eventual obstáculo que impede a sua aquisição.

Renan Falcão de Azevedo afirma que, “muito embora a classificação da posse seja feita em conformidade com vários critérios, nenhum deles se constitui num compartimento estanque, exatamente em função dos elementos comuns que aparecem em todas as situações”. ${ }^{103}$ Para exemplificar tal posicionamento, o autor destaca que "nem sempre os possuidores são movidos pelas mesmas intenções”, "nem sempre a posse tem a mesma origem”, e que "nem sempre, por fim, o possuidor tem a mesma carga de poder de exercício ou inflexão sobre a coisa possuída”.

Em vista disso, convencionou-se classificar a posse em dois grandes grupos: quanto à sua origem, posse justa e injusta, e quanto à intenção do possuidor, posse de boafé e de má-fé, divisões que levam em consideração elementos objetivos e subjetivos. Classifica-se a posse, ainda em decorrência da lei, quanto à "inflexão do poder do possuidor", ${ }^{104}$ ou, em outras palavras, “quanto à relação pessoa coisa”, ${ }^{105}$ em direta e indireta.

\subsubsection{Posse justa e injusta}

Buscando no direito romano o conceito de justum, Savigny relatou que, em matéria de posse, a justa possessio é uma posse a que tem direito, seja ela ou não uma verdadeira posse do ponto de vista jurídico. ${ }^{106}$ Verifica-se, pela análise de algumas passagens do Digesto, que o conceito dos vícios da posse se assemelhava à classificação

\footnotetext{
103 AZEVEDO, Renan Falcão de. Posse: efeitos e proteção, p. 57.

${ }^{104}$ Idem, ibidem, p. 76

105 TARTUCE, Flávio. SIMÃO, José Fernando. Direito civil. v. 4. Direito das coisas, p. 36.

106 "En materia de posesión, la palabra justum está tomada en su segundo sentido y significa por consiguiente la justa possessio una posesión a que se tiene derecho, sea o no jurídica bajo otro concepto” (SAVIGNY, M.F.C. de. Tratado de la posesión, p. 61).
} 
atualmente admitida. ${ }^{107}$ Moreira Alves, também fazendo referência aos textos romanos, afirma que “a posse iusta é protegida, pelos interditos possessórios, contra todos, inclusive contra o proprietário (mas cede à ação de reivindicação deste); a posse iniusta só é protegida contra terceiros, e não contra aquele em face de quem se adquiriu a posse mediante a utilização de um dos três uitia possessiones (vícios da posse)”. ${ }^{108}$

Tais conceitos não sofreram grandes alterações ao longo dos tempos, conservando-se ainda na atualidade a mesma compreensão sobre a posse injusta que prevalecia no direito romano. Antônio Joaquim Ribas, já na edição de seu livro de 1883, asseverava que "posse justa significa a que é isenta de vícios, isto é, a que não é adquirida com violência, clandestinidade, ou com abuso de confiança - vi, clam, aut precario”. 109 Para Laffayete, a "posse justa em sentido lato é aquela cuja aquisição não repugna ao Direito” e, em sentido restrito, “significa a que é isenta de algum dos três vícios”. 110

Seguindo esse entendimento, o Código Civil de 1916 dispôs em seu artigo 489 que é justa a posse “que não for violenta, clandestina ou precária”, redação integralmente conservada no artigo 1.200 do atual Código Civil, permitindo-nos classificar a posse injusta, portanto, como aquela em que estão presentes tais vícios.

Francisco Eduardo Loureiro critica a enumeração dos vícios da posse pelo Código Civil, visto que, segundo seu entendimento, melhor seria a abstração da norma para que fosse possível classificar como injusta a posse adquirida contra a vontade do possuidor, ressalvados os casos em que o desapossamento encontra previsão legal, ${ }^{111}$ de modo a evitar que, na prática, seja afastada a qualidade de injustiça da posse que foi adquirida por meio de esbulho, ainda que o ato não se enquadre nas hipóteses de violência ou clandestinidade.

${ }^{107}$ No Livro 41, 3, § 21, do Digesto, registrou-se o pensamento de Labeão: “se um particular partiu para a feira, deixando a casa vazia, se ao retornar encontrá-la ocupada por estranho, embora esse detentor possua clandestinamente, não perderá a sua posse. Se esse detentor opor-se ao ingresso do proprietário, na sua casa, o mesmo Labeão é de parecer que ele, então, possuirá antes violentamente do que clandestinamente”. Já na passagem do Livro 41, 3, § 17, encontra-se a assertiva de que "aquele que foi desapossado pela violência é considerado possuidor, porque tem, para recuperá-la, a faculdade de empregar o interdito de vi” (Tradução: MERÉJE, Rodrigues de. Teorias jurídicas da posse, p. 24 e 30).

${ }^{108}$ MOREIRA ALVES, José Carlos. Posse. Evolução histórica, v. 1, p. 43.

109 RIBAS, Antônio Joaquim. Da posse e das ações possessórias, p.34.

${ }^{110}$ PEREIRA, Lafayette Rodrigues. Direito das coisas. v. 1, p. 46

${ }^{111}$ LOUREIRO, Francisco Eduardo. In: PELUSO, Cezar (Coord.). Código Civil comentado, p. 1151. 
Apesar de interessante a ponderação do autor, seria difícil imaginar um ato ilícito praticado na aquisição da posse que não se enquadrasse em um dos vícios descritos na lei, porquanto, se a posse foi tomada contra a vontade do possuidor, só pode ter sido resultado de violência ou ameaça, e se houve autorização ou condescendência, estará configurada ao menos a permissão ou a tolerância, que não induzem a posse.

É relevante, para a determinação da posse injusta, o momento da sua aquisição, ou melhor, o ato ilícito praticado na tomada da coisa, que fica submetida ao poder do usurpador na condição de mera detenção enquanto perdurar o vício. Essa detenção se transformará em posse apenas no momento em que cessa o ato de violência ou de clandestinidade, mas essa posse será injusta em relação ao possuidor originário, uma vez que contra ele fora praticado ilícito que macula a situação do novo possuidor.

É violenta a posse adquirida por meio da força, exercida física ou moralmente, pela qual sucumbe o possuidor; adquire-se a posse pela violência, portanto, quando se configura o ato de força, ou mesmo a ameaça - séria e injusta -, que impõe ao possuidor a conduta omissiva de não resistir à ofensa para evitar um mal maior. ${ }^{112} \mathrm{O}$ importante, para que fique caracterizada a violência, é a falta de vontade do possuidor.

Protege-se, pois, a posse contra a violência para que, de um ato ilícito, não surja uma posse legítima. Nesse sentido, Tito Fulgêncio afirma:

[...] da desordem não pode nascer a legitimidade de um fato, e não pode ser justa ou legítima uma posse adquirida com violência, ou melhor, delituosamente; a própria índole da posse o impõe, porque a força ou a violência revela em quem a emprega, na maioria dos casos, o ânimo de usurpação, duvidando ele da justiça da pretensão, e na vítima, cedendo à violência, a ausência de intenção de renunciar a posse. ${ }^{113}$

Pouco importa, aliás, se a violência é praticada contra a pessoa do próprio possuidor ou àquele encarregado da guarda da coisa, o fâmulo da posse, devendo ser igualmente considerada a ilicitude para tornar injusta a posse dele originada. Desta forma,

\footnotetext{
112 “A coação moral também vicia a posse. Pode ocorrer, por exemplo, que o possuidor, ameaçado de sofrer retaliação por parte do esbulhador, abandone a coisa antes de sofrer agressão física, o que se mostra suficiente a rotular a posse assim adquirida como violente" (TEPEDINO, Gustavo. Comentários ao Código Civil. v. 14. Direito das coisas, p. 95).

${ }^{113}$ FULGÊNCIO, Tito. Da posse e das ações possessórias, p. 30.
} 
"não se indaga se a violência foi praticada contra o real possuidor ou em face do servidor da posse, bem como os motivos que a inspiraram, pois o vício é objetivo, sendo bastante a aquisição ilícita da coisa”. 114

Em relação à clandestinidade, trata-se de vício que se caracteriza quando a posse é adquirida por atos praticados às escondidas, sem o conhecimento do possuidor; é a "que se adquire via processo de ocultamento (clam), em relação àquele contra quem é praticado o apossamento". ${ }^{115} \mathrm{O}$ ato clandestino é ocultado somente do possuidor, podendo ser de conhecimento de todos os demais, pelo que se afirma que a clandestinidade é um defeito relativo, uma vez que a ocultação se refere apenas ao possuidor usurpado.

O possuidor não percebe a violação praticada contra o seu direito de posse e, em razão disso, não pode reagir para proteger sua condição de possuidor. Não é relevante a intenção do usurpador, bastando que a sua conduta no momento da obtenção da coisa seja desconhecida do possuidor. ${ }^{116}$

Cessa a clandestinidade, no entanto, quando o possuidor toma conhecimento da violência. Discute-se na doutrina se é exigível o conhecimento inequívoco do possuidor ou se basta a cessação da ocultação da conduta do usurpador, ou seja, se basta que se torne possível ao possuidor ofendido ter conhecimento da tomada da coisa por outrem. Entende Nelson Luiz Pinto que cessa a clandestinidade quando o usurpador torna possível à vítima tomar conhecimento da tomada da coisa por ele, ${ }^{117}$ posicionamento que nos parece mais acertado.

Enquanto perduram a clandestinidade e a violência, há mera detenção, como visto anteriormente (item 2.5.1). Quando cessam os vícios é que nasce a posse, mas injusta, porquanto oriunda de ato ilícito. Assim, a detenção se transforma em posse injusta no momento em que o possuidor toma conhecimento do esbulho ou da turbação cessam os atos ilícitos que deram causa à tomada da coisa. Lembre-se que, nesta situação, a detenção

\footnotetext{
${ }^{114}$ ROSENVALD, Nelson; FARIAS, Cristiano Chaves de. Direitos reais, p. 83.

115 PEREIRA, Caio Mário da Silva. Instituições de direito civil. v. 4. Direitos reais, p. 22.

116 “Não é necessária a intenção de esconder ou camuflar, porque o conceito é objetivo” (VENOSA, Sílvio de Salvo. Direito civil. v. 5. Direitos reais, p. 67).

${ }^{117}$ PINTO, Nelson Luiz. Ação de usucapião, p. 107.
} 
será aquela denominada independente, não devendo ser confundida com a detenção que decorre da vontade do possuidor, como no caso do fâmulo da posse. Tal observação deve ser consignada porque, do contrário, poder-se-ia imaginar que o possuidor esbulhado estaria impedido de propor ação possessória contra o detentor e ofensor enquanto não cessada a violência, em razão da norma do artigo 62 do Código de Processo Civil; a referida norma refere-se exclusivamente à detenção dependente, ou seja, aquele em que se detém a coisa em nome alheio, e não à detenção independente, que se inicia sem a vontade do possuidor.

É precária a posse quando o possuidor recebe a coisa com a obrigação de restituíla e, agindo com abuso de confiança, deixa de devolvê-la ao proprietário ou possuidor legítimo. ${ }^{118}$ Nessa hipótese, portanto, observa-se que a posse que era justa transforma-se em injusta, como ocorre no comodato, quando o comodatário, após decorrido o prazo do contrato ou notificado da sua rescisão, não devolver ao comodante a coisa, mantendo-se na posse em contrariedade à vontade do proprietário ou legítimo possuidor.

Como visto, a violência e a clandestinidade são vícios temporários, que cessam e permitem ao detentor adquirir a posse (injusta). Há divergência, contudo, quanto à possibilidade ou não de convalescência da precariedade. Silvio Rodrigues afirma que "o vício da precariedade macula a posse, não permitindo gere ela efeitos jurídicos”, e que não induzem "posse os atos de mera permissão ou tolerância, o que, decerto, abrange a posse precária”. 119

Entretanto, Francisco Eduardo Loureiro sustenta que esse entendimento de parte da doutrina decorre de "erro de perspectiva", pois, enquanto perdura a violência ou a clandestinidade, não haverá posse, mas sim mera detenção. Transformada a detenção em posse injusta, somente poderá haver conversão em posse justa se houver modificação na causa possessionis, ou seja, “a posse que era injusta converteu-se em justa, porque mudou a sua causa”. ${ }^{120}$ É o caso do possuidor violento, clandestino ou precário que ajusta com o

\footnotetext{
118 "Posse precária é [...] daquele que recebe a coisa com a obrigação de restituir, e arroga-se a qualidade de possuidor, abusando da confiança, ou deixando de devolvê-la ao proprietário, ou ao legítimo possuidor" (PEREIRA, Caio Mário da Silva. Instituições de direito civil. v. 4. Direitos reais, p. 23).

${ }^{119}$ RODRIGUES, Silvio. Direito civil. v. 5. Direito das coisas, p. 29.

${ }^{120}$ LOUREIRO, Francisco Eduardo. In: PELUSO, Cezar (Coord.). Código Civil comentado, p. 1153.
} 
possuidor usurpado um prazo para desocupação do imóvel, passando a possuí-lo a título de comodato por determinado período, situação que viabiliza a transformação da posse injusta em justa, em decorrência da mudança da sua causa originária.

Apesar de inquinada de vícios no momento da sua aquisição, a posse injusta gera efeitos jurídicos, inclusive de interditos contra terceiros porque os vícios da posse são relativos, já que valem para o possuidor usurpado, mas não aos terceiros, pois contra estes nenhuma violência fora praticada. Como consequência disso, tem-se que os possuidores injustos podem se valer dos interditos contra a ofensa praticada por terceiros, de modo a evitar a perpetuação dos atos ilícitos, que seriam corriqueiros se a posse injusta não fosse protegida.

Outra questão que se aborda com frequência é aquela relativa à possibilidade de considerar posse injusta como ad usucapionem. Sustenta-se que sim, desde que "durante o prazo necessário à usucapião não haja novos atos violentos ou clandestinos”, que não seja, assim, molestado o possuidor no transcorrer do prazo.

É certo, porém, que a posse precária não gera usucapião não em razão da injustiça, mas pela ausência do animus domini, visto que o possuidor nessa condição reconhece a supremacia e o melhor direito de terceiro sobre a coisa ${ }^{121}$. Todavia, Francisco Loureiro sustenta que, na hipótese de não reconhecer essa posição ou revelar isso de modo inequívoco ao proprietário, permitindo que este retome a coisa, nascerá, então, nesse momento, com a presença do animus domini, o prazo para usucapião. ${ }^{122}$

\subsubsection{Posse de boa-fé e de má-fé}

A posse será de boa-fé quando o possuidor ignorar o vício que impede a sua aquisição e, a contrario sensu, será considerado de má-fé o possuidor que, apesar de conhecer as circunstâncias de fato que se relacionam com o bem objeto da posse, não deixa

\footnotetext{
121 “Usucapião. Iimpossibilidade. Posse precária, oriunda de 'contrato de gaveta', realizado sem a anuência do agente financeiro Ausência de condições que configurem tratar-se de posse ad usucapionem Inocorrência da prescrição aquisitiva” (TJSP, Apelação 9134815-97.2008.8.26.0000, Rel. João Carlos Saletti, 10. ${ }^{\text {a }}$ Câmara de Direito Privado, DJ 18.12.2012).

${ }^{122}$ LOUREIRO, Francisco Eduardo. In: PELUSO, Cezar (Coord.). Código Civil comentado, p. 1153.
} 
de adquiri-lo e, com isso, "conscientemente, assume o risco de sofrer as consequências jurídicas advindas de sua manifestação de vontade”. ${ }^{123}$

Nesse sentido, dispõe o artigo 1.201 do Código Civil que “é de boa-fé a posse, se o possuidor ignora o vício, ou o obstáculo que impede a aquisição da coisa”.

Historicamente o instituto da posse esteve vinculado à boa-fé do adquirente, acarretando consequências diversas de acordo com a consciência e intenção do possuidor, como se observa em algumas passagens do Corpus Iuris Civilis. ${ }^{124}$ José Carlos Moreira Alves demonstra que a expressão possessio bonae fidei é usada nos textos romanos ora em sentido amplo, em que o possuidor ignora que esteja lesando o proprietário da coisa, e ora em sentido restrito, quando à posse de boa-fé se somam os demais requisitos para adquirir a propriedade por usucapião. Encontra-se nos textos, ainda, a possessio malae fidei, em que o possuidor sabe que está lesando o direito do proprietário, e não tem, por isso, a possibilidade de adquirir por usucapião, mas pode se valer dos interditos. ${ }^{125}$

Nota-se, pela transcrição do Digesto (nota 42), que no direito romano era exigida a boa-fé apenas no começo, no momento da aquisição da posse, para que o possuidor fosse considerado de boa-fé. No direito canônico, porém, exige-se “a boa-fé não somente ao tempo da aquisição, mas também em seguida, durante todo o tempo do gozo, estabelecendo o seguinte princípio: mala fides superveniens interrumpit usucapionem”. ${ }^{26}$

Astolpho Rezende analisou as legislações de diversos países e constatou que elas têm seguido dois sistemas diferentes para determinar a noção de posse de boa-fé e regular seus efeitos jurídicos: um sistema de fato e outro de direito. Segundo o autor,

[...] o primeiro funda-se na realidade efetiva da boa-fé, existente no ânimo do possuidor; este estado íntimo deve certamente deduzir-se de

\footnotetext{
${ }^{123}$ NERY JUNIOR, Nelson; NERY, Rosa Maria de Andrade. Código Civil comentado, p. 943.

124 "Digesto: Livro 41, 40, § 2: “Comprei, de boa fé, de Tício, um escravo teu, e o possui, tendo me sido entregue; depois, quando descobri que era teu, ocultei-o para que nem por isso parece que possuo clandestinamente por esse tempo; porque si também antes tivesse eu comprado um escravo teu a outro, e começasse a possuí-lo clandestinamente, mesmo que depois te cientificasse, nem por isso deixaria de possuir clandestinamente” (Tradução: MERÉJE, Rodrigues de. Teorias jurídicas da posse, p. 44).

${ }^{125}$ MOREIRA ALVES, José Carlos. Posse. Evolução histórica, p. 42.

${ }^{126}$ REZENDE, Astolpho. A posse e sua protecção. v. 1, p. 405-406.
} 
atos e fatos externos; estes, porém, não têm valor em si, mas só enquanto servem para indagar da honestidade da consciência daquele que possui. ${ }^{12}$

Nesse sistema, portanto, prepondera a moral sobre o direito na decisão judicial, uma vez que o juiz forma sua convicção a partir de uma análise altamente subjetiva.

No segundo sistema, Astolpho Rezende sustenta que seu nascimento se deu em período em que o direito se libertou do domínio da indagação psicológica, “e funda-se, a par da realidade da boa-fé, na realidade de certas condições de fato, externas, de que normalmente se origina a boa-fé e às quais a lei atribui a eficácia de fazê-las presumir". ${ }^{28}$ Seguindo essa orientação, nos países em que legislação é adepta a esse sistema, o juiz deve buscar os fatos externos que a lei considera juridicamente corretos, sendo irrelevante a investigação sobre a consciência do possuidor.

Assim como nas legislações influenciadas pelo direito romano e derivadas do Código Civil francês, no Brasil também se adotou o primeiro sistema, o que se depreende do artigo 1.201 do Código Civil, que amarra o conceito de boa-fé com o elemento anímico do possuidor, qual seja a ignorância deste acerca do obstáculo que impede a aquisição da posse justa, de modo que, para constatar a boa-fé do possuidor, o juiz deverá, a partir de quaisquer circunstâncias, desvendar qual é a sua intenção.

Sabe-se que a expressão boa-fé comporta duas divisões, quais sejam a objetiva e a subjetiva. Na primeira, positivada pelos artigos 113 e 422 do Código Civil, estabelece-se um padrão de comportamento que deve estar presente nos atos e negócios jurídicos, de modo a permitir, a partir de dados concretos, apurar se existe ou não a boa-fé. Quanto à boa-fé subjetiva, é o desconhecimento dos vícios que recaem sobre determinada situação jurídica.

Ensina José Rogério Cruz e Tucci que a boa-fé lealdade tem relevância no campo dos direitos obrigacionais, visto que integra a vontade dos contratantes, ao passo que a boa-

\footnotetext{
${ }^{127}$ REZENDE, Astolpho. A posse e sua protecção. v. 1, p. 398.

${ }^{128}$ Idem, ibidem.
} 
fé crença se manifesta, em regra, na esfera dos direitos reais. ${ }^{129} \mathrm{Em}$ seguida, conclui o autor que "a boa-fé - 'buena fe subjetiva' - aparece quando o possuidor tem certeza da legitimidade de sua posse, imaginando que o bem possuído lhe pertence”.

A análise do artigo 1.201 do Código Civil deixa clara a escolha do legislador por essa concepção, visto que define a posse de boa-fé como aquela em que o possuidor ignora os vícios que impedem a aquisição da posse justa, ou seja, prevalece no campo da posse a boa-fé subjetiva.

Somam-se, para a configuração da posse de má-fé, um elemento objetivo, que é o vício ou o obstáculo que impede a sua aquisição, e outro subjetivo, consistente na ignorância do possuidor acerca dos vícios. Assim, “esses elementos concorrem para tornarse de boa-fé a posse". 130

Sustenta-se na doutrina que não basta a ignorância do vício (concepção psicológica) para caracterizar a posse de boa-fé, e que, para tanto, é exigível que o estado de ignorância seja desculpável (concepção ética), pois somente o erro escusável seria compatível com a boa-fé. ${ }^{131}$ É correta essa teoria, desde que o conceito de erro inescusável seja variável, levando em conta as peculiaridades de cada caso. Se o denominado erro inescusável for identificável a partir de um padrão de conduta aplicado indistintamente a qualquer situação, estar-se-ia aplicando à posse a boa-fé objetiva, visto que se partiria de um modelo de comportamento para definir se, em uma situação concreta, teria ou não o possuidor condições de ter conhecimento do vício da sua posse; se seria desculpável a sua ignorância. E, se assim fosse, em vez da investigação da consciência do possuidor a partir de fatos concretos, seria estabelecido um modelo de comportamento sem o qual não haveria boa-fé, o que, evidentemente, não se coaduna com a norma do artigo 1.201 do Código Civil.

Diversa é a situação da utilização da presunção para concluir se o possuidor tem ou não conhecimento dos vícios que obstaculizam a aquisição da posse justa. A presunção,

\footnotetext{
${ }^{129}$ CRUZ E TUCCI, José Rogério. Da posse de boa-fé e os embargos de retenção por benfeitoria. In: CAHALI, Yussef Said (Coord.). Posse e propriedade, p. 612.

${ }^{130}$ BESSONE, Darcy. Da posse, p. 108.

${ }^{131}$ LOUREIRO, Francisco Eduardo. In: PELUSO, Cezar (Coord.). Código Civil comentado, p. 1155.
} 
como se sabe, está prevista no artigo 212, inciso IV, do Código Civil, e nada mais é do que o raciocínio do juiz que, partindo de um fato conhecido (fato incidiário), faz presumir como verdadeiro um fato desconhecido. ${ }^{132}$ Desta forma, é relevante a compreensão do instituto da presunção na investigação da boa-fé do possuidor, pois, sempre que se exige a análise da intenção do homem para decidir no processo, sendo impossível entrar em sua mente e conhecer seus pensamentos, somente a verificação das circunstâncias concretas pode dar ao juiz condições de averiguar, por meio da presunção hominis, a consciência do possuidor e, a partir daí, considerar presente ou ausente a boa-fé.

É oportuna, nesse sentido, a afirmação de Gustavo Tepedino, de que "ao intérprete incumbe definir o padrão de comportamento a ser exigido do possuidor, à luz das peculiaridades sociais, culturais, econômicas e regionais”.

Quando há boa-fé, a consciência e a crença do possuidor na legitimidade da sua posse podem ou não corresponder à realidade, ou seja, é possível que sua convicção surja de um erro de fato ou de direito. ${ }^{133}$ Segundo Roberto de Ruggiero,

[...] quanto à boa-fé, consiste ela aqui na ignorância dos vícios do título, e de acordo com a sua essência assenta num erro, que pode ser de fato ou de direito, isto é: que pode dizer respeito a um fato, que o possuidor ignore, ou a uma norma jurídica, da qual o possuidor desconheça a existência ou não avalie suficientemente as consequências jurídicas. ${ }^{134}$

Questiona-se a possibilidade de a boa-fé do possuidor estar relacionada a um erro de direito, ${ }^{135}$ porquanto, nessa situação, deveria prevalecer a regra de que a ninguém é

132 "São presunções judiciais (hominis) as ilações que o juiz extrai da ocorrência de certos fatos para concluir que outro fato tenha acontecido, com eficácia restrita a cada caso em que julga. Essas ilações são fruto de sua própria construção inteligente ou do alinhamento a outras anteriormente fixadas em casos precedentes pelos tribunais, com a constância suficiente para caracterizar determinadas linhas jurisprudenciais" (DINAMARCO, Cândido Rangel. Instituições de direito processual civil, v. 3, p. 121).

133 “De boa-fé está aquele que tem a convicção de que procede na conformidade das normas. Esta opinião poderá corresponder à realidade, mas é também possível que se origine de um erro, de fato ou de direito, quanto à legitimidade da posse" (PEREIRA, Caio Mário da Silva. Instituições de direito civil. v. 4. Direitos reais, p. 24).

${ }^{134}$ RUGGIERO, Roberto de. Instituições de direito civil. v. 2. Direitos de família. Direitos reais e posse, p. 644.

${ }^{135}$ O erro de direito, segundo Cláudia Cimardi, poderia ser exemplificado pela situação do possuidor que imagina ter a propriedade somente porque possuiu uma escritura de cessão de direitos possessórios, o que seria um erro, visto que essa escritura não teria aptidão para transmitir o direito real de propriedade (CIMARDI, Cláudia Aparecida. Proteção processual da posse, p. 48). 
dado o direito de desconhecer a lei, entendimento sustentado por parte da doutrina. Por seu turno, Tito Fulgêncio defende que, embora seja certo que ninguém se escusa com a alegação de erro ou ignorância, o que poderia conduzir ao entendimento de que o possuidor não poderia alegar que não tinha conhecimento dos vícios inerentes à aquisição da posse, a própria lei autoriza a anulação de atos jurídicos eivados de erro substancial, pelo que conclui o autor que não seria "errônea a alegação de erro determinante para justificação de boa-fé e o ser atendido no domínio de uma lei, que permite ela mesma, em certos casos, a invocação de semelhante escusa”. ${ }^{136}$

Roberto de Ruggiero faz referência à proibição da alegação de desconhecimento da lei para sustentar que tal preceito, embora seja verdadeiro, aplica-se em atenção à obrigatoriedade das normas, mas não é aplicável nos casos em que a ignorância é invocada dessas normas para fugir aos seus preceitos, e sim "para evitar as consequências danosas de um ato praticado sob o império de um erro de direito ou para manter os efeitos favoráveis de um tal ato". ${ }^{137}$

Também segue esse entendimento Sílvio de Salvo Venosa, para quem, em algumas situações, “o erro (e também a ignorância) de direito, de lei não cogente, pode caracterizar posse de boa-fé, enquanto não alertado ou não ficar ciente o possuidor”. ${ }^{38}$

Parece-nos correto admitir que o erro de direito não afasta a boa-fé posicionamento da maior parte dos doutrinadores -, porquanto tal admissão não afronta a regra que impede o desconhecimento da lei. No entanto, nessa situação o possuidor terá o ônus de comprovar que desconhecia a disposição legal que tornou viciosa a aquisição da coisa. $^{139}$

\footnotetext{
${ }^{136}$ FULGÊNCIO, Tito. Da posse e das ações possessórias, p. 32.

${ }^{137}$ RUGGIERO, Roberto de. Instituições de direito civil. v. 2. Direitos de família. Direitos reais e posse, p. 645.

${ }^{138}$ VENOSA, Sílvio de Salvo. Direito civil. v. 5. Direitos reais, p. 70.

139 “Somos dos que entendem que o erro de Direito pode ser invocado nos termos já expostos em comentário anterior. Pelas razões já expostas nas anotações ao artigo $5 .^{\circ}$ da Introdução, tanto mais quanto a regra, como é sabido, comporta exceções” (CARVALHO DOS SANTOS, J. M. de. Código Civil brasileiro interpretado, v. 7, p. 44).
} 
Há presunção relativa de boa-fé quando há justo título; assim dispõe o parágrafo único do artigo 1.201 do Código Civil: “o possuidor com justo título tem por si a presunção de boa-fé, salvo prova em contrário, ou quando a lei expressamente não admite esta presunção".

Entende-se por “título” não necessariamente um instrumento ou documento, mas sim o fato gerador do direito, ou seja, a causa que deu origem à situação da posse, enquanto o termo “justo” remete à aptidão de que goza o título para constituir ou transmitir o direito à posse. “Diz-se ‘justo’ o título hábil em tese para transferir a propriedade. Basta que o seja em tese, isto é, independente de circunstâncias particulares ao caso.”140

Sílvio de Salvo Venosa sustenta que o "justo título configura estado de aparência que permite concluir estar o sujeito gozando de boa posse", ${ }^{141}$ e exemplifica com a situação do herdeiro aparente, que o desconhecimento da existência de outros herdeiros faz presumir ser ele justo possuidor.

Tem-se como justo o título que em tese é capaz, em tese, de transmitir a posse ou a propriedade, e que, por peculiaridades do caso concreto, torna-se inapto para efetivar a transmissão, seja pela existência de algum defeito ou pela ausência de requisitos exigidos pela lei. Nos dizeres da Cláudia Aparecida Cimardi, “o justo título é, pois, aquele que poderia transferir a propriedade, se não contivesse um vício qualquer, quanto à forma ou aos requisitos legais exigidos à sua validade”. ${ }^{142}$

Isto é, o justo título, mesmo não sendo apto a transferir a posse ou o domínio, é assim considerado simplesmente por aparentar ser hábil à transmissão do direito, por ser capaz de induzir a erro o possuidor. ${ }^{143}$ Cite-se, por exemplo, o compromisso de compra e venda, ou o contrato de locação ou de comodato, mesmo verbal, firmado com que não tem

\footnotetext{
${ }^{140}$ RIZZARDO, Arnaldo. Direito das coisas, p. 47.

${ }^{141}$ VENOSA, Sílvio de Salvo. Direito civil. v. 5. Direitos reais, p. 72.

142 CIMARDI, Cláudia Aparecida. Proteção processual da posse, p. 50.

143 “Com efeito, para que seja justo o título da posse, não é preciso que efetivamente transfira o domínio. Basta que tenha em si mesmo as condições precisas para transferi-lo; embora por falta do direito no transferente não se possa operar essa transferência” (RIBAS, Antônio Joaquim. Da posse e das ações possessórias, p. 58).
} 
o domínio ou a posse. Essa relação jurídica é vista como causa legítima ao direito de posse, visto que é apta, em tese, a transferir esse direito.

Vale ressaltar que o justo título exigido para a usucapião é diferente daquele que gera presunção de boa-fé do possuidor. O próprio exemplo do contrato de locação ou de comodato já demonstra essa diferença, pois, embora gere presunção de boa-fé do possuidor, não tem eficácia para fins de aquisição via usucapião. "Vê-se, portanto, que o comodatário e o locatário têm justo título para efeito de presunção e boa-fé, mas não para gerar usucapião ordinária.”144

A presunção de boa-fé gerada pelo justo título é relativa, juris tantum, admitindo, portanto, prova em contrário. Tal presunção, assim como qualquer outra presunção legal e relativa, influi no ônus processual para inverter a regra, isto é, "serve apenas para dispensar o possuidor do ônus da prova, transferindo-a a quem contesta a boa-fé”, ${ }^{145}$ mas, se for provada a má-fé, cai por terra a presunção. “Assim como não pode prevalecer na hipótese da lei expressamente não admitir essa presunção, como, por exemplo, no caso do esbulhador violento."146

O Código Civil dispõe, em seu artigo 1.202, que a posse perde o caráter de boa-fé "no caso e desde o momento em que as circunstâncias façam presumir que o possuidor não ignora que possui indevidamente”, vale dizer, a posse, embora tenha sido exercida desde o início pelo possuidor de boa-fé, transforma-se em posse de má-fé a partir do momento em que o possuidor toma conhecimento do vício que a macula, o que será constatado a partir de circunstâncias concretas. Lembre-se, como destacado alhures, que nesse ponto o nosso sistema jurídico se afastou da orientação do direito romano - segundo o qual a posse se mantinha de boa-fé desde que esse caráter tenha prevalecido no momento da aquisição, pouco importante se depois o possuidor tomou conhecimento do vício - e aderiu ao conceito desenvolvido no direito canônico.

\footnotetext{
${ }^{144}$ LOUREIRO, Francisco Eduardo. In: PELUSO, Cezar (Coord.). Código Civil comentado, p. 1156.

${ }^{145}$ CARVALHO DOS SANTOS, J. M. de. Código Civil brasileiro interpretado, p. 44.

${ }^{146}$ Idem, ibidem, p. 45.
} 
E “cabe ao retomante demonstrar a má-fé do possuidor”, e “essa prova, porém, torna-se mais fácil, decorrente, segundo a dicção do artigo em exame, das circunstâncias indicativas do conhecimento do vício pelo possuidor”. ${ }^{147}$ Deve-se, portanto, averiguar em que momento essas circunstâncias autorizam a presunção de que o possuidor tem conhecimento do vício que macula sua posse, e assim, portanto, terá relevância “o exame objetivo do cenário fático capaz de comprovar a conversão da posse”. 148

Encontram-se na doutrina e na jurisprudência entendimentos diversos acerca do momento em que deveria ser o possuidor considerado ciente do vício que inquina a sua posse. De um lado, há quem sustente que as circunstâncias objetivas é que indicarão se e quando o possuidor teve ciência do obstáculo à aquisição da posse justa, por exemplo, a situação daquele que adquire um imóvel de um menor sem assistência ou representação, mesmo conhecendo essa incapacidade. Outra parte dos juristas defende que o momento da cessação da boa-fé seria o da citação no processo judicial, ou mesmo da notificação judicial ou extrajudicial; há os que defendem, ainda, o momento da apresentação da contestação no processo judicial. ${ }^{149}$

Quer nos parecer que esse momento de cessação da boa-fé deve ser alternado de acordo com as circunstâncias de cada caso concreto, dado que seria impossível fixar um critério que pudesse ser aplicado a qualquer litígio. Mesmo no caso da citação no processo judicial, por meio da qual o possuidor tem ciência inequívoca do alegado vício, pode-se supor que o possuidor continue a se julgar possuidor de boa-fé, e que não tem razão o autor em suas razões.

Nesse sentido, mostra-se correto o posicionamento de Orlando Gomes, para quem “a posse de boa-fé pode perder esse caráter antes de iniciada qualquer ação judicial, como pode sobreviver, nesse caráter, à litiscontestatio”. Isso porque, assevera o autor, “as circunstâncias podem ser tão notórias que, sem qualquer procedimento judicial de quem

\footnotetext{
${ }^{147}$ LOUREIRO, Francisco Eduardo. In: PELUSO, Cezar (Coord.). Código Civil comentado, p. 1157.

148 TEPEDINO, Gustavo. Comentários ao Código Civil. v. 14. Direito das coisas, p. 110.

149 “Ora, no momento da contestação da lide, o possuidor fica conhecendo as alegações apresentadas pela parte contrária e mais do que isso fica conhecendo os documentos em que se estriba o direito de quem com ele consente. De sorte que, sem forçar a conclusão, é possível admitir-se, desde então, a presunção de que o possuidor, do momento da contestação da lide, não mais podia ignorar que possuía indevidamente” (CARVALHO DOS SANTOS, J. M. de. Código Civil brasileiro interpretado, p. 49-50).
} 
quer que seja, façam, de logo, presumir que o possuidor possui indevidamente”, ou, "por outro lado, a despeito de acionado, o possuidor pode conservar a convicção de que possui legitimamente". 150

Como bem concluiu José Rogério Cruz e Tucci, seria “impossível solucionar esse problema à luz de regras apriorísticas inflexíveis”, e por isso "o posicionamento mais adequado, e que ganha adeptos em nossos dias, é o de examinar-se acuradamente litígio por litígio, situação por situação" ${ }^{151}$ Assim como a verificação da boa-fé deve partir de circunstâncias concretas para constatar se o possuidor realmente desconhecia os vícios que o impediam de adquirir a posse justa, também o momento da cessação da boa-fé deve se dar a partir de fatos concretos que revelem a consciência do possuidor; em ambas as situações, é preciso presumir a intenção do possuidor com base em elementos objetivos, e das circunstâncias do caso concreto.

O Código Civil também prevê o que se denomina na doutrina de "princípio da continuidade do caráter da posse”, ao regulamentar, em seu artigo 1.213, que, "salvo prova em contrário, entende-se manter a posse o mesmo caráter com que foi adquirida”. Assim, é possível a alteração do caráter da posse, de boa-fé para má-fé, e justa em injusta, ou viceversa, e deve ser compreendida como "caráter da posse a modalidade viciosa ou isenta de vícios, direta ou indireta, de boa ou de má-fé, a título de propriedade ou autorizada pelo titular do domínio". ${ }^{152}$

Entretanto, estabelece a codificação atual que é presumível a manutenção do caráter inicial, o que importa afirmar que terá o ônus da prova aquele que alega a mudança do caráter da posse, seja das qualidades positivas (boa-fé e justiça da posse) ou negativas. Ou seja, a inversão do caráter da posse não decorre da vontade do possuidor - regra que decorre da máxima do direito romano nemo si ipsi causam possessionis mutare potest -, mas deve ser comprovada a partir das circunstâncias concretas por aquele que pretende se beneficiar dessa mudança do estado inicial, seja o possuidor que deseja demonstrar a

\footnotetext{
${ }^{150}$ GOMES, Orlando. Direitos reais, p. 52.

${ }^{151}$ CRUZ E TUCCI, José Rogério. Da posse de boa-fé e os embargos de retenção por benfeitoria. In: CAHALI, Yussef Said (Coord.). Posse e propriedade, p. 617.

152 TEPEDINO, Gustavo. Comentários ao Código Civil. v. 14. Direito das coisas, p. 113.
} 
conversão da sua posse injusta em justa, seja do usurpado que pretende demonstrar a instauração da posse precária, por exemplo.

Seguindo esse entendimento, Darcy Bessone afirma que "não poderia o ato volitivo unilateral modificá-lo”. Sustenta o autor: “a esse ponto de vista, que de um modo geral é acolhido, abre-se exceção no caso em que a modificação não decorra apenas de ato de vontade, mas, sim, de ato material exterior e inequívoco”. E conclui: “verifica-se, nessa hipótese, a interversão do título não apenas por efeito da vontade, mas por efeito da exteriorização dela, através de atos concretos e materializados”. 153

Em conclusão, importa ressaltar que as classificações da posse como justa ou injusta e, sobretudo, como de boa ou má-fé, é de extrema relevância para definir uma série de consequências jurídicas que variam de acordo com o caráter da posse. Dispõe o artigo 1.214 do Código Civil, por exemplo, que o possuidor de boa-fé tem direito aos frutos percebidos da coisa, enquanto pela norma do artigo 1.216 o possuidor de má-fé responde por todos os frutos colhidos e percebidos, bem como pelos que, por culpa sua, deixou de colher.

No âmbito do processo, tem grande importância essa classificação, visto que ao possuidor de boa-fé é dado não apenas o direito à indenização pelas benfeitorias úteis e necessárias, como também o direito de retenção da coisa, ${ }^{154}$ conforme dispõe o artigo 1.219 do Código Civil, que não cabe ao possuidor de má-fé, a quem apenas é assegurada a indenização pelas benfeitorias necessárias, sem a retenção da coisa.

\subsubsection{Posse direta e indireta}

Segundo Pontes de Miranda, alguns autores tentaram derivar do direito romano o conceito de mediatização da posse, mas não conseguiram, uma vez que a sua origem é

\footnotetext{
153 BESSONE, Darcy. Da posse, p. 110

154 “Contudo, é de observar-se que somente ao possuidor de boa-fé é assegurado o direito de retenção a fim de que seja ele ressarcido das despesas efetuadas. O ius reteintionis consiste, assim, num meio de defesa outorgado ao credor, a quem é reconhecida a faculdade de continuar com a coisa alheia em seu poder enquanto não for indenizado pelo crédito decorrente das benfeitorias por ele erigidas” (CRUZ E TUCCI, José Rogério. Da posse de boa-fé e os embargos de retenção por benfeitoria. In: CAHALI, Yussef Said (Coord.). Posse e propriedade, p. 618).
} 
germânica. ${ }^{155}$ Moreira Alves sustenta que somente no período justinianeu o direito romano admitiu a organização horizontal da posse, prevendo o seu desdobramento ao admitir que duas pessoas pudessem ter diversas posses sobre a mesma coisa, muito embora se negasse a possibilidade de exercício da posse integral por diversas pessoas sobre uma mesma coisa (plurium in solidum), e que "a organização vertical da posse só viria a nascer nos direitos germânicos, como meio de estendê-la a situações que, no direito romano, permaneceram como detenção em face da posse a título de propriedade». 156

Astolpho Rezende sustentou que Savigny encontrou nos jurisconsultos romanos duas escolas: uma, liderada por Labeão e Paulo, ${ }^{157}$ que negava a possibilidade de exercício da posse por duas pessoas ao mesmo tempo, e outra, defendida por Trebacio, Sabino e Juliano, que admitia a posse conjunta, mas somente quando um tivesse a posse justa e outro a posse injusta. ${ }^{158}$

Savigny separou a situação de transferência da posse no direito romano em três classes. Em uma delas, que se exemplificava pelo mandatário e pelo comodatário, a transferência da detenção não implicaria a transferência da posse; em outra, identificada na situação do enfiteuta e do credor pignoratício, haveria apenas a posse derivada, que também denomina de posse fictícia; ainda, na hipótese do depositário e do precarista, somente em caso excepcional haveria a transferência da posse, quando assim convencionassem as partes.

Desse modo, Savigny não reconhece a posse desses que recebem a coisa em razão de que lhes faltaria o animus domini, e então desenvolve a figura da posse derivada, atribuindo-a ao enfiteuta e ao credor pignoratício, e às vezes ao depositário e ao precarista - levando sua teoria à contradição, visto que admitiu haver posse sem animus domini -,

\footnotetext{
155 PONTES DE MIRANDA, Francisco Cavalcanti. Tratado de direito privado, t. X, p. 98.

${ }^{156}$ MOREIRA ALVES, José Carlos. Posse. Evolução histórica, v. 2, p. 288-292.

157 Digesto, Livro 41, T.2, 1.3, § 5. ${ }^{\circ}$ : “Plures eamdem rem in solidum possidere non possunt” (Tradução: Uma pluralidade de pessoas não pode possuir a mesma coisa indivisivelmente).

158 REZENDE, Astolpho. A posse e sua protecção. v. 1, p. 186.
} 
negando-a na situação do comodatário, do locatário e a outros em igual condição. ${ }^{159}$ Com isso, pela teoria de Savigny, ficariam sem o direito à proteção possessória esses últimos.

O posicionamento defendido por Savigny suscitou acirrada discussão na doutrina, tendo sido na obra de Ihering rebatido de forma coesa e fundamentada. ${ }^{160}$ Para Ihering, não é condição para o exercício da posse o animus dimini, mas sim o animus sibi habendi, isto é, a intenção de ter a coisa como sua. Dessa forma, Ihering dividia a situação do proprietário e do comodatário em posse mediata, ou indireta, exercida por aquele, e imediata, ou direta, atribuída a este último.

Segundo Caio Mário da Silva Pereira, esse “deslocamento a título convencional” da posse somente era comportado pela teoria de Ihering, "pois que basta à determinação da posse que se proceda em relação à coisa como o faz o proprietário (posse = visibilidade do domínio), e aquele que a recebe numa destinação econômica usa-a como o faria o proprietário”. Igualmente se posiciona Francisco Eduardo Loureiro, para quem “a figura da posse direta somente tem sentido na teoria objetiva de Ihering, uma vez que para Savigny e para os defensores da teoria subjetiva a ausência de animus domini a converte em mera detenção”. ${ }^{161}$

No Brasil, a organização vertical da posse vem da época do Império, por influência das codificações germânicas do século XIX e, segundo Moreira Alves, aparece no Esboço de Teixeira de Freitas como posse perfeita e imperfeita. O Código Civil de 1916 exemplificava, em seu artigo 486, quem eram os possuidores diretos, dispondo que o usufrutuário, o credor pignoratício e o locatário, ao exercerem a posse direta (inferior), não anulariam a posse indireta (superior).

Nesse aspecto, a codificação atual melhorou sobremaneira a redação do correspondente dispositivo, ao regulamentar que "a posse direta, de pessoa que tem em seu poder, temporariamente, em virtude de direito pessoal, ou real, não anula a indireta, de

\footnotetext{
159 "La Posesión del enfiteuta. Como esta posesión es determinada en general, pero al mismo tiempo sin el animus domini, no puede ser considerada sino como una posesión derivada. [...] En lo concerniente al depositum, la regla no admite duda alguna. En general, la posesión tanto aquí como en el arrendamiento, no se enajena" (SAVIGNY, M.F.C. de. Tratado de la posesión, p. 182-196).

${ }^{160}$ IHERING, Rudolf von. O fundamento dos interdictos possessórios, p. 318.

${ }^{161}$ LOUREIRO, Francisco Eduardo. In: PELUSO, Cezar (Coord.). Código Civil comentado, p. 1144.
} 
quem aquela foi havida, podendo o possuidor direto defender a sua posse contra indireto" (art. 1.197, CC), visto que o desdobramento da posse não ocorre apenas naquelas situações previstas pelo legislador, a exemplo da situação do comodatário.

Por meio desse artifício, o proprietário ou possuidor legítimo dispõe da coisa com o objetivo de obter algum proveito econômico, entregando-a a terceiro que passa, então, a exercer poderes sobre o bem. Será deste, portanto, a posse direta, visto que terá consigo a coisa, apreendendo-a fisicamente com a intenção simplesmente de tê-la temporariamente como sua, independentemente de animus domini e sem retirar do proprietário ou possuidor antecedente o seu direito, a sua posse indireta.

José Paulo Cavalcante sustentou que “o proprietário, o enfiteuta e o usufrutuário [...] não têm nenhum poder de fato sobre a coisa, quando esteja locada ou dada em comodato", e se referiu o mesmo autor à "falsa posse indireta”, que assim denominou por considerar que o poder de fato do possuidor é a "possibilidade presente e concreta, e não somente futura e abstrata, de atuação sobre a coisa”. ${ }^{162}$ Contudo, negar a condição de possuidor do locador seria negar o desdobramento da posse, dado que a sua transferência temporariamente a terceiro apenas decorre do poder do possuidor ou proprietário de dispor da coisa de acordo com seus interesses, conservando para si o poder de retomar o bem no prazo estabelecido. O possuidor direto é aquele a quem corresponde a pretensão de entrega da coisa. ${ }^{163}$

Pontes de Miranda, por outro lado, afirmou que "posse mediata é a que se tem por sobre outra, que serve de mediadora para o poder fático”, e ressalta que não se deve exagerar o papel de mediação, visto que “o possuidor mediato está em plano superior; é a sua posição, aí, que o faz superior; - não a existência do possuidor imediato”. ${ }^{164}$ Apesar de se denominar de superior a posse indireta e inferior, a direta, deve-se compreender que não

\footnotetext{
162 CAVALCANTI, José Paulo. A falsa posse indireta.

163 “Poseedor mediato es únicamente aquel a quien corresponda la pretensión de entrega” (ENNECCERUS, Ludwig. KIPP, Theodor. WOLFF, Martín. Tratado de derecho civil. t. III, 1. ․ Derecho de cosas, p. 59). "Entende a doutrina alemã que só é possuidor mediato aquele que tem uma pretensão válida no sentido de lhe ser entregue a coisa sobre a qual se exerce o poder do possuidor imediato; e ainda mais que somente o titular dessa pretensão tem a qualidade de possuidor mediato” (ESPÍNOLA, Eduardo. Posse Propriedade. Compropriedade ou condomínio. Direitos autorais. Conquista, p. 56-57).

${ }^{164}$ PONTES DE MIRANDA, Francisco Cavalcanti. Tratado de direito privado, t. X, p. 95.
} 
há competição ou hierarquia, no que tange à posse, entre os possuidores. Como sustentou Serpa Lopes, em relação aos possuidores direto e indireto, “não há posses rivais senão posses que se exercem harmonicamente, uma confirmado logicamente a outra”. 165

Fala-se em duplicidade da posse sobre um mesmo bem, visto que a posse direta, ou imediata, passa a ser exercida por terceiro, sem que isso subtraia a condição do proprietário ou do possuidor antecedente que a transferiu temporariamente; para que ocorra esse desdobramento da posse, pressupõe-se a existência de uma relação jurídica entre os possuidores direto e indireto, conforme ensina Enneccerus. ${ }^{166}$ Embora Pontes de Miranda discorde de tal posicionamento, ${ }^{167}$ não há como refutar que entre os possuidores direto e indireto há relação jurídica; há também relação de fato, mas configura relação jurídica. ${ }^{168}$

Nesse sentido, Gustavo Tepedino assevera que a bipartição da posse é resultado, em regra, de uma convenção entre as partes, mas que pode também ser originada de relações jurídicas previstas em lei, “decorrentes do direito de família, no caso da posse dos pais em relação aos bens dos filhos sob sua autoridade parental, e do direito sucessório, na posse do inventariante sobre os bens do espólio". ${ }^{169}$ Sendo assim, o desdobramento da posse será sempre resultado de relação jurídica, seja de natureza obrigacional ou real, que podem ser exemplificadas, respectivamente, pelo contrato de comodato e pelo usufruto.

Atente-se ainda para o caráter temporário do desdobramento que, previsto no texto da lei, impõe limitação no tempo para o exercício da posse direta, vinculando-a sempre ao título causal do qual é derivada. Não apenas a limitação temporal se impõe à posse direta, mas também no tocante aos poderes inerentes ao possuidor imediato, sendo

\footnotetext{
${ }^{165}$ SERPA LOPES, Miguel Maria. Curso de direito civil. p. 128.

166 "La posesión mediata presupone, aparte de una posesión del mediador, una cierta relación entre el poseedor superior y el sob poseedor. Este tiene que poseer la cosa a título de usufructuario, acreedor pignoraticio, arrendatario, depositario o en una relación semejante, en virtud de la cual esté temporalmente facultado u obligado frente a otro a la posesión. Es claro que se requiere una relación jurídica que dé al poseedor mediato una pretensión de entrega contra el mediador" (ENNECCERUS, Ludwig; KIPP, Theodor; WOLFF, Martín. Tratado de derecho civil. t. III, 1. ${ }^{\circ}$ Derecho de cosas, p. 55).

167 “É erro exigir-se à posse mediata e à imediata existir entre elas relação jurídica [...] A relação não é jurídica - é fática, donde ser impertinente exigir-se-lhe validade ou eficácia jurídica” (PONTES DE PONTES DE MIRANDA, Francisco Cavalcanti. Tratado de direito privado, t. X, p. 95).

${ }^{168}$ Tal discussão, entretanto, importaria em resgatar a polêmica sobre a natureza jurídica da posse, se é fato ou direito, a qual já superamos em item anterior (item 2.3).

${ }^{169}$ TEPEDINO, Gustavo. Comentários ao Código Civil. v. 14. Direito das coisas, p. 75-76.
} 
identificável essa gradação na comparação entre o contrato de locação, que pode prever proibição de sublocação, ${ }^{170}$ e o usufruto, ao qual não se impõe tal impedimento.

Note-se, por oportuno, que, dependendo da forma como se estabelece a relação jurídica que desdobra a posse em direta e indireta, e possível a ocorrência de nova bipartição, com instauração de uma nova relação jurídica, a ponto de tornar indireto o possuidor direto. É o que ocorre, por exemplo, na hipótese de o usufrutuário alugar o imóvel, ou de o locatário sublocar, caso conste tal poder no contrato de locação.

É interessante, ainda, a observação feita por Renan Falcão, de que a posse direta pode existir sozinha, como na situação do possuidor usucapiente ou do proprietário, em que o exercício dos direitos possessórios é feito pessoalmente pelos respectivos titulares. ${ }^{171}$ Por outro lado, adverte Arnaldo Rizzardo que “dificilmente aparecerá tão somente a posse indireta, como no caso em que um proprietário não esteja ocupando ou usufruindo o bem”. 172

Em verdade, porém, parece-nos que, se não há a posse direta ou a indireta, é porque inexiste ou se encerrou o desdobramento da posse, não havendo sentido, portanto, em identificar como direta ou indireta a posse exercida apenas por uma pessoa; tal classificação somente é oportuna na hipótese de haver o desmembramento, de o possuidor ou proprietário transferir temporariamente a posse a um terceiro, pois, do contrário, haverá apenas posse, e não posse direta ou posse indireta. Nesse sentido, Orlando Gomes destacou que "a bipartição da posse só se verifica quando a coisa pertencente a alguém é entregue a outra pessoa, para que a utilize", e que "a figura do possuidor indireto surge somente quando a coisa se encontra no poder dessa pessoa”. ${ }^{173}$

\footnotetext{
170 “A posse direta há de ser expressão de um direito limitado. Daí a possibilidade de sua constituição sobre relação possessória já desdobrada, como no caso da sublocação, em que o locatário-sublocador, sendo possuidor direto em relação ao senhorio, passa a ser possuidor indireto em relação ao sublocatário" (GOMES, Orlando. Direitos reais, 59).

${ }^{171}$ AZEVEDO, Renan Falcão de. Posse: efeitos e proteção, p. 58.

172 RIZZARDO, Arnaldo. Direito das coisas, p. 50.

${ }^{173}$ GOMES, Orlando. Direitos reais, p. 58. No mesmo sentido: "Não se cogita de posse direta, no sentido da lei, na hipótese em que somente o proprietário exerce posse sobre a coisa” (CIMARDI, Cláudia Aparecida. Proteção processual da posse, p. 54).
} 
Ambas as posses coexistem, e o desdobramento em direta e indireta atribui aos dois possuidores o direito aos interditos, tanto para proteger o bem contra terceiros quanto para que um se defenda do outro, caso haja exercício irregular do respectivo direito. Se o proprietário invade o imóvel possuído diretamente pelo comodatário, comete ofensa à posse deste, que pode ser repelida por meio das ações possessórias, e de igual forma o possuidor indireto poderá se valer dos interditos para corrigir eventual abuso do possuidor direto, por exemplo, na hipótese de exploração de minérios sem autorização prevista no contrato firmado entre as partes.

Assim, tem-se como ponto de maior importância no desdobramento da posse a possibilidade de o possuidor direto utilizar-se dos interditos para se defender de ofensas praticadas contra a sua posse, ${ }^{174}$ mesmo que o ofensor seja o possuidor indireto, contra o qual poderá ser concedida a tutela jurisdicional para que se abstenha de molestar a posse do possuidor direto ou, ainda, para lhe restituir a coisa, caso tenha ocorrido esbulho.

\subsection{Composse}

Não se confunde o desdobramento da posse com a composse, que se caracteriza pela situação de dois ou mais indivíduos que exercem a posse sobre coisa indivisa. Nos termos do artigo 1.199 do Código Civil, "se duas ou mais pessoas possuírem coisa indivisa, poderá cada uma exercer sobre ela atos possessórios, contanto que não excluam os dos outros compossuidores”. Portanto, é comum a ambas as figuras a ausência de exclusividade da posse, mas “a distinção é que na composse há repartição quantitativa da posse”, e "nas posses direta e indireta há repartição qualitativa”. 175

Conforme José Carlos Moreira Alves, a composse vem do direito romano, e se caracteriza como possessio plurium pro indiviso, ou seja, posse de muitos pro indiviso, e não como possessio plurium in solidum, que é a posse solidária de muitos possuidores. ${ }^{176}$ Encontram-se nos textos romanos, entretanto, divergências entre os jurisconsultos, que os

\footnotetext{
174 "Esta divisão da posse obedece a uma necessidade prática: determinar, quanto às pessoas, a extensão da garantia possessória e assinar que consequências jurídicas se prendem à posse em toda a sua plenitude” (FULGÊNCIO, Tito. Da posse e das ações possessórias, p. 22).

${ }^{175}$ LOUREIRO, Francisco Eduardo. In: PELUSO, Cezar (Coord.). Código Civil comentado, p. 1150.

${ }^{176}$ MOREIRA ALVES, José Carlos. Posse. Evolução histórica, v. 2, p. 478.
} 
dividiam em duas escolas: uma, com Labeo e Paulus, negava de modo absoluto a possibilidade da composse, ${ }^{177}$ ao passo que outra, representada por Trebatius, Sabinus e Julianus, admitiam-na, mas de tal maneira que uma pessoa teria justa posse e outra, posse injusta. $^{178}$

Com fundamento nos textos romanos, Savigny nega a possibilidade da composse, sob o argumento de que, sendo a posse o poder físico que o homem exerce sobre a coisa com a intenção de ser dono, é preciso que o possuidor tenha condições de dispor da coisa da forma como entender melhor, sem que qualquer outra pessoa possa interferir no exercício de seu poder. Entretanto, aponta-se certa contradição dos romanos, visto que, embora neguem a possibilidade da composse, admitem e regulam o condomínio.

No direito alemão, são distintas as figuras da composse simples, que é a composse romana, na qual cada possuidor pode exercer isoladamente o poder de fato sobre a coisa, “e da composse em mão comum, que tem raízes no direito alemão antigo, e que se configura "quando somente todos os possuidores, em conjunto, podem exercer o poder de fato sobre a coisa”. ${ }^{179} \mathrm{O}$ autor alemão Martín Wolff distingue a composesión simple da posesión em mano común afirmando que, no primeiro caso, cada um tem poder independente sobre a coisa, mas não um poder ilimitado, posto que o outro compossuidor também compartilha a coisa, e que, na segunda hipótese, "nenhum dos compossuidores tem poder independente, sem que o tenham todos em conjunto; os possuidores vinculados são “o possuidor”. 180

177 Encontra-se no livro 41 do Digesto o texto de Paulo que representa esse entendimento de ser impossível o exercício da posse por várias pessoas sobre uma única coisa: Livro 41, Título II, III, § 4. ${ }^{\circ}$ : "ex plurimus causis possidere eandem rem possumus"; § 5. : "ex contrario plures eadem rem in solidum possidere non possunt, contra naturam quipe est, ut, quum ego aliquid teneam, tu quoque id tenere videaris". Tradução de Rodrigues de Méreje: § 4.: "Pode-se possuir a mesma coisa por várias causas ...”; § 5.: "Mas várias pessoas não podem ter in solidum a posse da mesma coisa. E com efeito contra a natureza, que, quando eu tenha uma coisa em minhas mãos, se possa crer que ela esteja também na vossa” (MERÉJE, Rodrigues de. Teorias jurídicas da posse, p. 18).

${ }^{178}$ REZENDE, Astolpho. A posse e sua proteç̧ão. v. 1, p. 372.

${ }^{179}$ MOREIRA ALVES, José Carlos. Posse. Evolução histórica, v. 2, p. 520.

180 “1. En el primer caso, cada uno tiene un señorío independiente sobre la cosa, si bien no un señorío ilimitado, puesto que también el otro coposeedor lo comparte. 2. Por el contrario, en la coposesión en mano común, ninguno de los coposeedores tiene un señorío independiente, sino que lo tiene todos en conjunto: los coposeedores vinculados son 'el poseedor'” (ENNECCERUS, Ludwig. KIPP, Theodor; WOLFF, Martín. Tratado de derecho civil. t. III, 1. ${ }^{\circ}$. Derecho de cosas, p. 65-66). 
Pontes de Miranda aderiu ao entendimento da doutrina germânica, e sustentou a existência de posse em mão comum no direito brasileiro, utilizando-se, para tanto, do exemplo do cofre bancário. Nessa situação e em outras, o autor entendeu que, assim como no direito germânico, haveria posse em mão comum porquanto nenhum dos possuidores teria o poder fático independente sobre a mesma coisa. A seu ver, as chaves complementares do cofre ficariam com o banco, e seria sua a posse do prédio e do cofre, sendo do cliente apenas a posse imediata do conteúdo do cofre. Com isso, somente o banco e o cliente poderiam exercer a posse sobre o cofre e seu conteúdo. ${ }^{181}$ No entanto, Moreira Alves conta que, em volume posterior do tratado de Direito Privado, ao estudar os contratos de caixas-fortes, Pontes de Miranda adotou posição diversa, admitindo que “o fato de ter o banco outra chave de modo nenhum influi para se dizer que ele tem posse imediata do espaço interior". ${ }^{182}$

Conforme se depreende do texto da lei, haverá composse quando duas ou mais pessoas exercerem posse sobre coisa indivisa, vale dizer, quando várias pessoas possuírem a mesma coisa sem divisão. ${ }^{183}$ A possibilidade da composse, ou compossessão, já foi negada por diversos doutrinadores, mas resistiu em razão de refletir a realidade. Senão, como seria explicada a situação do casal que exerce posse com iguais poderes sobre um imóvel residencial, sem delimitar espaço ou estabelecer alternância de uso. Tem-se, portanto, que o elemento principal para caracterização da composse é a indivisão da coisa possuída por duas ou mais pessoas.

\footnotetext{
181 "Quanto ao cofre mesmo, ou armário, ou gaveta, ou escaninho, o estabelecimento é possuidor, como proprietário, ou locador do prédio, com os móveis, se é caso, e o que tomou de aluguer alguma daquelas peças é possuidor imediato em composse simples com o próprio estabelecimento" (PONTES DE PONTES DE MIRANDA, Francisco Cavalcanti. Tratado de direito privado, t. X, p. 112).

${ }^{182}$ MOREIRA ALVES, José Carlos. Posse. Evolução histórica, p. 534.

183 “Conceitualmente, a composse (também denominada composse ou posse em comum) consiste no exercício simultâneo da posse por mais de um titular, com iguais faculdades, sobre a mesma coisa tomada em sua integralidade - e, por isso mesmo, tecnicamente reputada indivisa. Na composse, em que dois ou mais titulares possuem um mesmo objeto indiviso, seus respectivos direitos, embora, de ordinário, demarcados idealmente por frações abstratas do bem comum, hão de ser exercidos concomitantemente sobre o todo, e de tal modo que os atos possessórios de cada consorte não excluam os dos demais" (TEPEDINO, Gustavo. Comentários ao Código Civil. v. 14. Direito das coisas, p. 89).
} 
Washington de Barros Monteiro ${ }^{184}$ afirma que na posse pro diviso a compossessão subsiste de direito, mas não de fato, enquanto na posse pro indiviso existe compossessão de fato e de direito. No entanto, o exercício de posse pro diviso não configura a composse, visto que, nesta situação, haveria posse de pessoas sobre partes específicas de uma mesma coisa. ${ }^{185}$ É o que ocorre quando dois herdeiros dividem uma área rural em duas partes e passam a exercer posse cada um em uma dessas partes; não haveria composse, mas sim posse individual de cada pessoa sobre parte delimitada do imóvel.

Nesse sentido, “não há composse se três condôminos, por exemplo, ocupam, individualmente, partes certas e determinadas de um imóvel [...] cessa a composse pela divisão em partes certas do todo (posse pro diviso)" ${ }^{186}$ Por isso, "inexistindo o estado de indivisão, surge compossessio pro diviso, que é nada mais do que uma posse exclusiva sobre o bem comum”, e "não se configura uma autêntica composse”. ${ }^{187}$

É certo, porém, que na composse pode haver uma convenção dos possuidores de utilização do todo de forma organizada, a fim de que um não prejudique a posse do outro, e por isso, mesmo sem existir divisão física da coisa, nota-se que na composse pode haver “uma divisão puramente intelectual ou abstrata da posse”, mas “não se realiza uma divisão concreta”. ${ }^{188}$ Pela observação das situações concretas é possível verificar uma variação no grau dessa “divisão intelectual” da coisa. Na compossessão de um casal sobre o imóvel residencial, por exemplo, constata-se que nem mesmo no plano imaginário há divisão, visto que o homem e a mulher exercem a posse sobre a totalidade do bem, sem qualquer limitação. Já em um albergue, em que várias pessoas podem utilizar um mesmo quarto para

${ }^{184}$ BARROS MONTEIRO, Washington de; MALUF, Carlos Alberto Dabus. Curso de direito civil. v. 3. Direito das coisas, p. 89.

${ }^{185}$ Conforme esclarece Eduardo Espínola, “várias pessoas podem exercer direitos possessórios que incidam sobre a mesma coisa, em partes distintas, caso em que cada uma daquelas tem a posse relativa à sua parte. Se, entretanto, recaírem os seus direitos sobre uma coisa indivisa, ou estiverem no gozo comum do mesmo direito, verifica-se a compossessão, da qual resulta poder cada um dos possuidores exercer atos possessórios e a respectiva defesa, contanto que não excluam a atividade dos outros compossuidores” (ESPÍNOLA, Eduardo. Posse - Propriedade. Compropriedade ou condomínio. Direitos autorais. Conquista, p. 59).

${ }^{186}$ LOUREIRO, Francisco Eduardo. In: PELUSO, Cezar (Coord.). Código Civil comentado, p. 1149-1150.

${ }^{187}$ ARAÚJO, Fabio Caldas de. Posse, p. 194.

${ }^{188}$ BESSONE, Darcy. Da posse, p. 106. 
dormir, é possível que, mesmo sem haver divisão física da coisa, encontre-se alguma limitação entre os compossuidores de modo a permitir que a posse comum se desenvolva com harmonia.

Sobre essa questão, Fábio Caldas de Araújo explica que, embora cada compossuidor seja possuidor do todo, a ideia de parcela ideal que predomina na composse é o que justifica a permissão que cada possuidor possa ter na parte dos frutos produzidos no bem possuído em comum; “em outras palavras, a parte intelectual é um meio de autolimitação e explicitação de que a composse exige coordenação entre os seus titulares". 189

Urge compreender o que se denomina de “coisa indivisa”, pois causa estranheza, à primeira vista, que o caráter de indivisão possa se verificar na coisa divisível, isto é, pode ocorrer de a composse ser exercida sobre coisa divisível, mas de fato indivisa. Assim, o que importa para a configuração da composse é o estado de indivisão da coisa, ainda que ela seja divisível, “de tal modo que nenhum compossuidor exerça sua posse sobre uma parte distinta ou delimitada do objeto, mas sobre a coisa por inteiro”. ${ }^{190}$ Um imóvel rural pode estar dividido em lotes para fins de demarcação das áreas de cultivo, e por isso o seu uso poderia ser dividido entre os diversos possuidores, mas se os condôminos exercem a posse igualmente sobre a integralidade da coisa, sem distinção de área ou atribuição de parte específica a cada um, haverá composse.

Portanto, “cada compossuidor só pode exercer sobre a coisa atos possessórios que não excluam a posse dos outros compossuidores”. ${ }^{191}$ Guido Arzua, ao interpretar o texto do artigo 488 do Código Civil de 1916, ${ }^{192}$ afirma que, “no caso de indivisão do imóvel

\footnotetext{
189 ARAÚJO, Fabio Caldas de. Posse, p. 188.

190 TEPEDINO, Gustavo. Comentários ao Código Civil. v. 14. Direito das coisas, p. 89.

191 CARVALHO DOS SANTOS, J. M. de. Código Civil brasileiro interpretado, cit., p. 35.

192 “Art. 488. Se duas ou mais pessoas possuírem coisa indivisa, ou estiverem no gozo do mesmo direito, poderá cada um exercer sobre o objeto comum atos possessórios, contanto que não excluam os dos outros compossuidores.”
} 
comum, a posse de cada possuidor de uma parcela não pode excluir ou embaraçar a posse dos demais nas respectivas quotas”. ${ }^{193}$

Conclui-se, portanto, que, se todos os compossuidores têm direitos iguais em relação à coisa comum, cabe-lhes a sua utilização de modo que um não interfira no direito do outro, e certo de que nenhum possui a coisa integralmente, mas sim de forma comum. Tem-se, portanto, que, se um possuidor atrapalhar o exercício da composse, poderá qualquer um dos compossuidores afastá-lo por meio das ações possessórias. ${ }^{194} \mathrm{E}$ consequentemente, por ser cada um compossuidor do todo, terão legitimidade individual ou conjuntamente para a propositura dos interditos contra terceiros que ameaçarem o regular desenvolvimento da posse comum ${ }^{195}$.

Insta notar que a possibilidade de manejo dos interditos por qualquer dos compossuidores, assim como pelo possuidor direto ou indireto na situação da posse desmembrada, facilita o acesso à justiça e torna mais efetivo e célere o processo ao evitar o litisconsórcio necessário ativo, exigência que poderia inclusive inviabilizar a defesa da posse do todo em razão de eventual dissidência entre os compossuidores, e inclusive impedir a proteção conferida a um compossuidor contra o outro.

\subsection{Aquisição, transmissão e perda da posse}

Ao dispor sobre a aquisição da posse, o legislador seguiu, no artigo 1.204 do Código Civil, o conceito de possuidor presente no artigo 1.196, prevendo que "adquire-se a posse desde o momento em que se torna possível o exercício, em nome próprio, de qualquer dos poderes inerentes à propriedade”. Adquire a posse, portanto, “aquele que

\footnotetext{
${ }^{193}$ ARZUA, Guido. Posse. O direito e o processo, p. 39.

194 "A todos os compossuidores reconhece a lei iguais atributos, assegurando-lhes a todos a utilização da coisa comum, contanto que não interfiram no exercício, por parte dos outros, ou de qualquer deles, de iguais faculdades. Nenhum dos compossuidores possui a coisa por inteiro (Laffayete), porém cada um tem-lhe a posse por fração ideal. Se, pois, um perturbar o desenvolvimento da composse, poderá qualquer dos outros valer-se dos interditos, cujo alcance adstringe-se à contenção do compossuidor no respeito à posse dos outros” (PEREIRA, Caio Mário da Silva. Instituições de direito civil. v. 4. Direitos reais, p. 28).

195 “Condições da ação. Legitimidade passiva. Ação de reintegração de posse. Herdeiro que reclama o imóvel em nome do espólio. Possibilidade. Estado de composse que viabiliza a persecução do bem por qualquer dos herdeiros” (TJSP, Apelação 0101293-95.2009.8.26.0002, Rel. Helio Faria, 8. ${ }^{a}$ Câmara de Direito Privado, DJ 05.12.2012).
} 
procede em relação à coisa, em nome próprio, da maneira como o proprietário habitualmente o faz". 196

É interessante a crítica de José Carlos Moreira Alves em relação à expressão aquisição da posse, visto que, segundo o autor, sendo “a posse um fato, é impróprio dizerse que se adquire a posse, pois os fatos não se adquirem”, pelo que entende ser mais apropriada a expressão “início da posse". ${ }^{197}$ No entanto, essa questão nos faz regredir novamente à discussão da natureza jurídica da posse, sobre a polêmica de ser fato ou direito, debate já superado alhures com a conclusão de que, em matéria possessória, tanto o fato originário do direito quanto o próprio direito recebem a mesma denominação (posse). Com isso, ousa-se discordar do posicionamento do ilustre doutrinador, pois, ao utilizar a expressão “aquisição da posse”, o legislador quis evidentemente tratar da aquisição do direito, que autoriza não só a aquisição, como também a transmissão.

Podem ser diversos os modos de aquisição da posse. Pelo que reza o artigo 1.205 do Código Civil, ${ }^{198}$ a posse pode ser adquirida pela própria pessoa que a pretende ou por seu representante ou, ainda, por terceiro sem mandato, dependendo da ratificação.

Apesar das modificações implementadas pelo Código Civil de 2002, nota-se que no Código Civil de $1916^{199}$ já havia ficado bastante clara a opção do legislador brasileiro

\footnotetext{
${ }^{196}$ LOUREIRO, Francisco Eduardo. In: PELUSO, Cezar (Coord.). Código Civil comentado, p. 1160.

197 MOREIRA ALVES, José Carlos. Direito romano, p. 339

198 “Art. 1.205. A posse pode ser adquirida:

I - pela própria pessoa que a pretende ou por seu representante;

II - por terceiro sem mandato, dependendo da ratificação.”

199 “Art. 493. Adquire-se a posse:

I - pela apreensão da coisa, ou pelo exercício do direito;

II - pelo fato de se dispor da coisa, ou do direito;

III - por qualquer dos modos de aquisição em geral.

Parágrafo único. É aplicável à aquisição da posse o disposto neste Código, arts. 81 a 85.”

“Art. 494. A posse pode ser adquirida:

I - pela própria pessoa que a pretende;

II - por seu representante, ou procurador;

III - por terceiro sem mandato, dependendo de ratificação;

IV - pelo constituto possessório.”
} 
em romper com a teoria de Savigny também no que tange à aquisição da posse, porquanto, segundo a teoria clássica, “a posse não era transmissível por ato jurídico, sem que a este se unisse a apreensão real da coisa”, ${ }^{200}$ entendimento que se apoia nos textos romanos, donde emana a regra "et apiscimur possessio nem corpore, et animo; neque per se animo, aut per se corpore". 201

Para Savigny, portanto, a posse não poderia ser transmitida, tampouco seria possível a figura do sucessor do possuidor; haveria, sim, para o citado autor, uma nova posse, independentemente da posse do antecessor. Dessa forma, se a posse fosse adquirida por convenção entre as partes, não bastaria o mero consentimento, sendo necessário o ato externo de apreensão da coisa. ${ }^{202}$

Ihering, entretanto, explicou que a exigência da apreensão física da coisa para a aquisição da posse no direito romano decorria do pensamento de uma “época bárbara”, em que os homens, incultos e grosseiros, não tinham conhecimento senão daquilo que podiam colher com a mão. ${ }^{203}$ Segundo Ihering, “é um erro assentar a aquisição da posse exclusivamente sobre o ato de apreensão do possuidor”, pois entende o autor que seria um excesso de formalidade impor ao autor essa apreensão, e obrigá-lo a estar fisicamente presente junto à coisa a fim de adquirir a sua posse, pois “a simples vista da cousa - a apreensão não é necessária para adquirir a posse - em nada muda sua posição”. 204

Destacou Astolpho Rezende que o Código Civil brasileiro se ajustou à legislação do século XIX, já inaugurada pelo Código da Prussia, de 1794, que foi o primeiro a estabelecer o princípio da transmissão consensual da posse, ao dispor que "a simples declaração de vontade do possuidor basta para consagrar o abandono da posse em proveito de outro, desde que esteja este assim colocando em estado de dispor da coisa”. ${ }^{205}$

\footnotetext{
${ }^{200}$ REZENDE, Astolpho. A posse e sua protecção. v. 1, p. 286.

${ }^{201}$ Digesto, Livro 41, 3, § 1. : "Alcançamos a posse com o corpo e com o ânimo, e não somente com um ou com outro” (Tradução: MERÉJE, Rodrigues de. Teorias jurídicas da posse, p. 22).

202 "La noción de lacto exterior que unido al animus nos da la posesión, está ya enteramente determinada."

203 REZENDE, Astolpho. A posse e sua protecção. v. 1, p. 287.

204 JHERING, Rudolf von. O fundamento dos interdictos possessórios, p. 254-255.

205 REZENDE, Astolpho. A posse e sua protecção. v. 1, p. 287.
} 
Lafayette Rodrigues Pereira sustentou, ao interpretar os artigos 493 e 494 do Código Civil de 1916, logo após seu advento, que a posse sem apreensão é "uma criação abstrata da lei, notável ainda por outras particularidades”, e levou em conta, para chegar a tal conclusão, que a posse que se transfere por sucessão, pela qual "adquirem os herdeiros, legítimos ou escritos, independentemente de apreensão de sua parte, a posse civil que tinha o defunto".206

É comum encontrar na doutrina a classificação da posse como civil e natural, sendo a posse civil aquela que se adquire como consequência de uma relação jurídica, sem necessariamente haver a apreensão da coisa, e como posse natural o resultado do simples comportamento de possuidor, sem a necessidade de haver relação jurídica anterior que confira o direito à posse.

No entanto, prevalece na doutrina a classificação binária da aquisição da posse em originária e derivada, que igualmente considera a vontade unilateral ou bilateral atuante no início da posse. A posse originária, segundo Sílvio de Salvo Venosa, é aquela "que ocorre sem qualquer vinculação com possuidor anterior”, em que “o ato do agente é unilateral”, 207 ou seja, na aquisição originária o exercício do poder físico sobre a coisa é realizado unicamente por aquele que tem interesse em tomá-la para si, não dependendo da vontade de qualquer outra pessoa para ter início a situação da posse; é o que acontece quando alguém toma a posse de um imóvel abandonado. Darcy Bessone destaca que na aquisição por ato unilateral é que "se encontra a fonte mais frequente das questões possessórias, o que se explica pela circunstância de não se fundar a posse em título provindo de outra pessoa interessada”. ${ }^{208}$ Já a posse derivada resulta de uma relação jurídica, em que a bilateralidade de vontades é elemento caracterizador da sua aquisição, ou no caso de morte, pelo princípio da saisine; em outras palavras, a posse derivada "pressupõe a translatividade, pela qual há um transmitente que perde a posse, e um adquirente que a adquire". 209

\footnotetext{
${ }^{206}$ PEREIRA, Lafayette Rodrigues. Direito das coisas. v. 1, p. 57.

${ }^{207}$ VENOSA, Sílvio de Salvo. Direito civil. v. 5. Direitos reais, p. 80.

${ }^{208}$ BESSONE, Darcy. Da posse, p. 119.

${ }^{209}$ RIZZARDO, Arnaldo. Direito das coisas, p. 58.
} 
Tratando-se de posse derivada, o apossamento da coisa se configura com a tradição (entrega), que ocorre quando a coisa é deslocada para a posse de outra pessoa. A doutrina distingue a tradição em efetiva, simbólica e consensual.

A tradição efetiva, também denominada real, ocorre com o deslocamento da posse, quando a coisa é materialmente entregue a outra pessoa, como na entrega de um veículo pela concessionária ao comprador. Essa modalidade de tradição é referida nas fontes antigas como traditio longa manu, pela qual o transmitente apresenta e põe a coisa à disposição do adquirente. Quando for meramente simbólica a tradição, a transferência será representada por um ato que não importa na efetiva entrega da coisa, mas que simplesmente simboliza essa transmissão; é o caso da entrega de chaves de um imóvel no contrato de locação. E, quanto à tradição ficta, “é aquela que se dá por presunção, como ocorre na traditio brevi manu, em que o possuidor possuía em nome alheio e passa a possuir em nome próprio”, 210 e igualmente no constituto possessório.

Embora não conste mais expressamente do Código Civil, o constituto possessório é instituto ainda aplicável, tanto que o Enunciado 77 da I Jornada de Direito Civil de 2004 dispôs que “a posse das coisas móveis e imóveis também pode ser transmitida pelo constituto possessório”. Não é indispensável, nesse sentido, a previsão legal específica do constituto possessório para que por esse meio se transmita a posse; seu cabimento decorre do próprio sistema e dos princípios gerais. Ocorre o constituto possessório quando o possuidor de uma coisa em nome próprio passa a possuí-la em nome alheio, como na situação do alienante que conserva a coisa em seu poder por meio da denominada cláusula constituti, ${ }^{211}$ recebendo o adquirente a coisa por mera convenção, e sem a posse física.

Conforme bem definido por Cristiano Chaves de Farias e Nelson Rosenvald, há, no constituto possessório, uma inversão na situação da posse em razão de uma relação jurídica, pois “aquele que possuía em nome próprio, com animus domini, passa a possuir em nome alheio, remanescendo o seu poder material sobre a coisa, mas não mais como

210 TARTURCE, Flávio; SIMÃO, José Fernando. Direito civil, v. 4, p. 80.

211 “Cláusula constituti não se presume. Deve constar expressamente do ato, ou resultar de estipulação que a pressuponha, como quando o vendedor, transferindo a outrem a propriedade da coisa, a conserva todavia em seu poder, a título de locação” (BARROS MONTEIRO, Washington de; MALUF, Carlos Alberto Dabus. Curso de direito civil. v. 3. Direito das coisas, p. 47). 
proprietário, porém a outro título”. 212 Por força da clausula constituti, que pode ser inserida, por exemplo, na escritura de compra e venda, o alienante, que exercia a posse em nome próprio, permanecerá na posse do bem, mas exercendo-a em nome alheio, do comprador, que fictamente adquire a posse indireta do bem.

Casos há em que o vendedor permanece temporariamente na posse do imóvel a título de locatário ou comodatário, seja porque vendeu o bem a um investidor que pretende alugá-lo, seja porque negociou abatimento no preço pela permanência gratuita no imóvel por um período após a compra e venda. É de grande valia, em situações tais, a inserção da clausula constituti na escritura, visto que, com isso, o comprador adquire a posse no momento da lavratura do documento, podendo se valer das ações possessórias caso o alienante não desocupe o imóvel. Na ausência dessa cláusula, o comprador nessa situação deveria ajuizar ação de imissão na posse, visto que, sem jamais ter exercido a posse - ainda que pela ficta traditio -, não poderia dispor dos interditos.

Consigne-se, porém, que a cláusula constituti, por si só, não prova a posse, mas tão somente o acordo entre constituinte e constitutário quanto à sua transferência, vale dizer, o constituto possessório não faz presumir a existência e legitimidade da posse transferida. $^{213}$ É possível imaginar a situação de um proprietário que compra um imóvel para investimento sem, entretanto, tomar posse do bem; caso logo em seguida, ou no mesmo ato, transfira a propriedade para outrem, mesmo com a cláusula constituti na escritura, o segundo adquirente não terá a posse, visto que o primeiro nunca a teve.

O direito brasileiro consagrou o princípio da saisine, segundo o qual a morte do possuidor acarreta a transmissão automática da posse aos herdeiros, sem que, para tanto, seja necessária a apreensão da coisa. Dispõe o artigo 1.206 do Código Civil que "a posse transmite-se aos herdeiros ou legatários do possuidor com os mesmos caracteres”. A posse será transmitida com as mesmas qualidades daquela exercida pelo de cujus, vale dizer, continuará a ser direta ou indireta, de boa-fé ou de má-fé, se assim era a posse do falecido.

\footnotetext{
212 ROSENVALD, Nelson; FARIAS, Cristiano Chaves de. Direitos reais, p. 96

213 “Se o constituinte não tem posse, a cláusula constituti é ineficaz. Nem o ter constituído prova a posse [...] a cláusula constituti não prova, por si só, posse efetiva. O que prova plenamente a cláusula constituti é a transferência da posse, ainda que não esteja o título transcrito, mas não prova a própria posse, que, como é intuitivo, pode existir, ou deixar de existir na pessoa do alienante, por ocasião do ato translativo" (PONTES DE MIRANDA, Francisco Cavalcanti. Tratado de direito privado, t. X, p. 169).
} 
O artigo 1.207 do Código Civil trata da conjunção e da transmissão das posses, dispensando-se tratamento distinto ao dispor: “o sucessor universal continua de direito a posse do seu antecessor; e ao sucessor singular é facultado unir sua posse à do antecessor, para os efeitos legais”. ${ }^{214}$ Na aquisição a título singular, de modo derivado, por ato inter vivos, o adquirente que recebe a posse tem a faculdade de juntá-la ou não à posse anterior. Pode o adquirente somar a sua posse à do antecessor para fins de usucapião, a fim de obter o tempo necessário para tanto, mas pode, entretanto, não ser interessante tal junção, se a posse do antecessor era de má-fé, visto que, se somadas, a nova posse continuará com o mesmo caráter da anterior.

Tem-se, portanto, que a transmissão da posse pode se dar a título universal ou singular. Na transmissão a título singular, como se viu, ocorre quando se transfere coisa determinada, como acontece por atos inter vivos. A título universal se dá a transferência da universalidade do patrimônio, como na sucessão mortis causa, em que o herdeiro, sucessor universal, "sucede em uma universalidade uma quota-parte da herança, uma fração não individualizada”. ${ }^{215}$ Embora a transferência a título singular esteja na maioria das vezes relacionada aos atos inter vivos, e aquela a título universal se relacione quase sempre com a sucessão mortis causa, é possível que se invertam as causas, ou seja, pode haver, por exemplo, transmissão a título singular quando se institui legatário no testamento, e transmissão a título universal na hipótese de transferência de estabelecimento comercial.

É importante ressaltar que não há forma para o negócio relativo à transmissão da posse; "não há requisito formal para a transmissão da posse, que, assim, pode ser verbal, desde que provada de modo concludente”. ${ }^{216}$ Nos atos entre vivos, os modos de aquisição da posse são todos os meios de transmitir e adquirir direitos, ou seja, atos jurídicos a título

\footnotetext{
214 “A questão maior está na exata compreensão da expressão 'sucessor universal'. Sabe-se que a transmissão pode dar-se a título universal ou singular. Universal quando se transmite todo o patrimônio ou fração ideal dele. Singular quando se transmite a coisa certa ou destacada do patrimônio. Via de regra, a sucessão universal dá-se a título causa mortis e a singular a título inter vivos. Isso, porém, nem sempre acontece. Pode perfeitamente ocorrer a transmissão universal por ato inter vivos, por exemplo, no casamento pelo regime da comunhão universal de bens, ou pela incorporação/fusão de pessoas jurídicas, assim como a transmissão singular causa mortis, como nos legados" (LOUREIRO, Francisco Eduardo. In: PELUSO, Cezar (Coord.). Código Civil comentado, p. 1163).
}

${ }^{215}$ VENOSA, Sílvio de Salvo. Direito civil. v. 5. Direitos reais, p. 89.

${ }^{216}$ LOUREIRO, Francisco Eduardo. In: PELUSO, Cezar (Coord.). Código Civil comentado, p. 1164. 
oneroso ou gratuito, seja um contrato de compra e venda, seja um simples instrumento de cessão de direitos possessórios.

Perde a posse o possuidor quando não se comporta mais como dono, deixando de dar à coisa destinação econômica, ou seja, deixando de conservá-la ou de defendê-la. É o que dispõe o art. 1.223 do Código Civil: "perde-se a posse quando cessa, embora contra a vontade do possuidor, o poder sobre o bem, ao qual se refere o art. 1.196”.

Perde-se a posse pelo abandono, que ocorre quando o possuidor abdica da posse por ato unilateral, e pela tradição, com a transmissão da posse e entrega da coisa ao adquirente. Enquadra-se na tradição, como visto, o constituto possessório, por meio do qual o alienante conserva o poder físico sobre a coisa em nome de outro. ${ }^{217} \mathrm{Na}$ falta do elemento objetivo (corpus), perde-se a posse pela destruição ou perda da coisa.

Assim, "só se considera perdida a posse para quem não presenciou o esbulho, quando, tendo notícia dele, se abstém de retornar a coisa, ou, tentando recuperá-la, é violentamente repelido”. É o que dispõe o texto do artigo 1.224 do Código Civil. Enquanto persiste a clandestinidade, terá o ocupante mera detenção, visto que o possuidor foi impossibilitado de reagir contra a tomada da coisa por lhe ter sido ocultado o ato pelo usurpador.

Tomando conhecimento da ocupação indevida da coisa por terceiro, poderá o possuidor (i) expulsar o ocupante por meio da autotutela, não chegando sequer a ocorrer a perda da posse, (ii) tentar retomar a coisa e ser repelido pelo usurpador, momento em que terá perdido a posse, ou, ainda, (iii) nada fazer ao tomar conhecimento da ocupação, o que igualmente implicará a perda da posse. A determinação do momento da perda da posse tem relevância para o cômputo do prazo de ano e dia exigido para a concessão de liminar nas ações possessórias, bem como para viabilizar o procedimento especial.

${ }^{217}$ A doutrina visualiza duas formas de constituto possessório. A primeiro, a que parte da doutrina reputa ser a única forma de constituto possessório, é a do alienante que conserva o poder da coisa em nome de outro, ou seja, como mero detentor. A outra é a do alienante que permanece na posse a título de locatário ou comodatário. Por vezes ocorre de o alienante negociar abatimento do preço do imóvel vendido em troca da sua permanência no bem por determinado período a título de comodato. 


\section{TUTELA PROCESSUAL DA POSSE}

\subsection{Fundamentos da proteção da posse}

As divergências existentes entre as teorias objetiva e subjetiva, desenvolvidas para explicar o fenômeno possessório, recaem, essencialmente, sobre os seguintes elementos: a natureza jurídica da posse - se é fato ou direito, e para quem entende que é direito, se é real ou pessoal -, a importância que se dá ao elemento anímico e o fundamento da proteção possessória.

Entretanto, parece-nos que a divergência mais relevante na atualidade refere-se ao fundamento da proteção possessória, dado que as teorias contemporâneas da posse sustentam que sua proteção não é um mero postulado da propriedade, e que tem como objeto a posse por si mesma, fortalecendo, portanto, a situação do mero possuidor.

Como visto anteriormente, os estudiosos do direito romano demonstram que a defesa da posse se iniciou na fase de distribuição do ager publicus, pois não poderia o beneficiário fazer prevalecer sua garantia dominial porquanto lhe faltava o título, incompatível com a condição das terras públicas.

Segundo Caio Mário da Silva Pereira,

[...] por toda a Idade Média, como nos tempos modernos do direito, quer nos países em que a propriedade é sedimentada nas bases de velha tradição, quer naqueles outros em que a competição pelo aproveitamento de amplas extensões territoriais dá maior ênfase à affectio tenendi sempre a posse ocupa a mais relevante função social, e sua proteção reclama maior atividade do aparelho jurídico. ${ }^{218}$

É daí, julga o autor, que resulta a imponência da indagação que se formula aos juristas, de qual seria o fundamento da tutela processual da posse. Mostra-se relevante, portanto, a análise das teorias que buscaram esclarecer qual o fundamento para a dispensa de proteção à posse.

${ }^{218}$ PEREIRA, Caio Mário da Silva. Instituições de direito civil, v. 4, p. 30. 
Astolpho Rezende observou que existem inúmeras teorias sobre o porquê dessa proteção, e as reuniu em dois grandes grupos: as teorias filosófico-positivas, que admitem uma razão fundamental para a proteção concedida pela lei, e se subdividem em relativas e absolutas, e as teorias histórico-negativas, que se limitam a expor as razões históricas que deram ensejo ao seu aparecimento nos primeiros tempos do direito romano. ${ }^{219}$

Ihering explica que as teorias relativas da posse fundamentam-na não em si mesma, mas “em considerações, instituições e preceitos jurídicos estranhos a ela”, isto é, não se protege a posse, que por si mesma seria inconcebível, mas para resguardar outros direitos. Já as teorias absolutas da posse, afirma Ihering, "tratam de conceber a posse em si mesma”, visto que sustentam a sua proteção não em razão de considerações que lhe são estranhas, mas sim por si própria, em virtude de ser a posse reconhecida juridicamente. ${ }^{20}$

Em relação às teorias relativas, observa-se que existem explicações diversas para a proteção da posse. Savigny fundamenta a proteção possessória na pessoa do possuidor, afirmando que a perturbação da posse é um delito contra o possuidor, e por isso se a protege. ${ }^{221}$ Rudorff, destaca Ihering, entende que a perturbação da posse é um atentado à

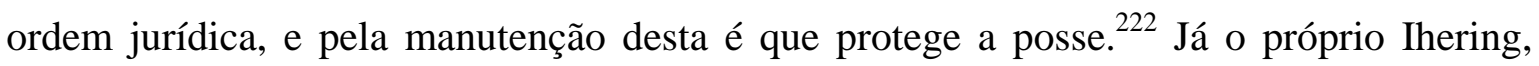
também adepto da teoria relativa da posse, fundamenta sua proteção na propriedade, afirmando que para proteger o direito de propriedade é que se concede proteção à posse. Compartilham do mesmo entendimento Silvio Rodrigues ${ }^{223}$ e Tito Fulgêncio, porém, para este último doutrinador, “a razão de ser da proteção possessória está no interesse da propriedade, cuja defesa ela completa”. 224

\footnotetext{
${ }^{219}$ REZENDE, Astolpho. A posse e sua proteç̧ão, v. 1, p. 431.

${ }^{220}$ IHERING, Rudolf von. O fundamento dos interditos possessórios, p. 11.

221 “El derecho de la posesión se funda en la protección concedida al simple ejercicio de la propiedad contra violaciones cometidas bajo formas determinadas. Estas formas de violación, así como esta protección, son concebibles de la misma manera con respecto a otros derechos que forman las partes constitutivas de la propiedad y están separados de esta última (jura in re)" (SAVIGNY, M.F.C. de. Tratado de la posesión, p. 291).

${ }^{222}$ IHERING, Rudolf von. O fundamento dos interditos possessórios, p. 12.

${ }^{223}$ RODRIGUES, Silvio. Direito civil. v. 5. Direito das coisas, p. 54.

${ }^{224}$ FULGÊNCIO, Tito. Da posse e das ações possessórias, p. 183.
} 
Os autores que desenvolveram as teorias absolutas, entretanto, defendem que a posse é protegida por si mesma. Ihering, ao discorrer sobre as teorias absolutas, destaca o entendimento de Stahl, segundo quem a posse, assim como a propriedade, "satisfaz o destino geral do patrimônio, serve para satisfação das necessidades humanas por meio das cousas”. ${ }^{225}$ Subdividem-se as teorias absolutas em duas principais, sendo uma baseada na vontade, segundo a qual a posse, como ato de manifestação de vontade, deve ser protegida, assim como qualquer outra pretensão não contrária à lei, e outra relacionada à posse em si mesma, que, nessa concepção, é uma forma de utilização dos bens, devendo ser protegida pelo ordenamento jurídico para garantir a satisfação das necessidades do homem.

Pontes de Miranda afirmou, ao considerar as teorias sobre o fundamento da proteção possessória, que a "tutela jurídica possessória assenta em que há interesse geral em se assegurar a ordem fática, para que nada se mude, sem ser dentro de paz, ou por decisão de justiça”, e que "somente a deliberação dos homens, sem violência, e a aplicação das leis, se houve desrespeito a elas, devem poder mudar os estados de fato existentes”. 226 Embora se possa encontrar nesse conceito a mesma ideia central das teorias relativas, de não fundamentar na posse a sua proteção, o autor repele expressamente, e em tom de crítica, as teorias que explicam a proteção possessória a partir da necessidade de proteção da pessoa, do delito ou da propriedade. ${ }^{227}$

O espanhol Antonio Hernandéz Gil, um dos representantes da teoria contemporânea da posse, defende, em sua obra La Función Social de la Posesión, que o fundamento da posse repousa na garantia da segurança jurídica, de modo a impedir que se altere injusta e ilegitimamente uma situação de fato. ${ }^{228}$

\footnotetext{
${ }^{225}$ IHERING, Rudolf von. O fundamento dos interditos possessórios, p. 66.

${ }^{226}$ PONTES DE MIRANDA, Francisco Cavalcanti. Tratado de direito privado, t. X, p. 284.

227 “Assim, ficam afastadas as teorias que atribuíram a proteção possessória: a) ao fato de estar contida (ou ser necessária) à proteção da personalidade (absurdo, que se vê ainda em E. Brodman, no Kommentar de G. Plank, III, 4. ed., 33); b) a ser delito o usar-se de força (F. von Savigny, A. F. Rudorff, A. Brinz); c) a ser complemento necessário da proteção da propriedade (R. von Ihering), o que levaria a explicar-se a posse do ladrão como efeito reflexo; d) a ser simples ofensa ou desconsideração à vontade” (PONTES DE MIRANDA, Francisco Cavalcanti. Tratado de direito privado, t. X, p. 285).

228 "La razón de seguridad jurídica que determina la tutela de las situaciones posesorias está constituida esencialmente por el mantenimiento de un statu quo en tanto se decida su conformidad o no con el ordenamiento jurídico” (HERNÁNDEZ GIL, Antonio. La función social de la posesión, p. 95).
} 
Após analisar as teorias absoluta e relativa sobre a proteção da posse, Ihering expõe a sua opinião nos seguintes termos:

[...] a protecção da posse, como exterioridade da propriedade, é um complemento necessário da protecção da propriedade, uma facilidade de prova em favor do proprietário, que necessariamente aproveita também ao não proprietário. 229

Em seguida, Ihering afirma que não poderia conceber um estado jurídico unicamente na propriedade, com exclusão dos interditos possessórios, isto é, um estado em que seria necessário fazer prova da propriedade para reprimir uma violência. Assim, Ihering exemplifica sua ideia sustentando que, se houvesse tal situação, em toda perturbação possessória o proprietário deveria prevalecer-se de sua propriedade, e não de sua posse; deveria, portanto, em cada caso de roubo ou de violência contra a posse fazer prova da propriedade.

Entretanto, Ihering considera que a prova da propriedade é extremamente difícil, e que, por isso, o proprietário deve contar com o privilégio de poder defender seu bem comprovando apenas a posse, e não a propriedade. Confira-se:

De accordo com o que dicto fica, pode-se considerar a posse como uma posição, como um reducto da propriedade. Não é por ella que se lhe concede protecção, é em consideração á propriedade. Na posse, o proprietário se defende contra os primeiros ataques ao seu direito. Neste terreno não se dá uma batalha decisiva para a propriedade, mas uma simples escaramuça, uma guerrilha em que, para continuar a comparação, não é necessaria a grossa artilheria, mas basta a arma branca: - contra o ladrão e o salteador não se emprega o canhão! Foi, pois, em attenção á propriedade que se introduziu a protecção da posse. $^{230}$

Assim, além de defender o privilégio de poder proteger um bem comprovando apenas a posse, e não a propriedade - sob a ideia de que a posse faz presumir a propriedade -, Ihering expõe o fundamento que permite entender qual a razão para a vedação à exceção de propriedade.

\footnotetext{
${ }^{229}$ IHERING, Rudolf von. O fundamento dos interditos possessórios, p. 71.

${ }^{230}$ Idem, ibidem, p. 81.
} 
À primeira vista, a vedação à exceção de propriedade pode parecer uma contradição com a teoria objetiva de Ihering, pois assim seria possível conceder a proteção processual da posse ao não proprietário. Entretanto, a proibição da alegação do direito de propriedade em defesa na ação possessória é a garantia de que o autor da demanda, ao pedir a proteção da sua posse, não será instado pelo réu a comprovar a sua propriedade. Isso porque de nada adiantaria dar ao proprietário o privilégio e a facilidade de proteger o seu bem comprovando apenas a posse, se o réu pudesse, em defesa, alegar que tem o direito de propriedade e obrigar o autor, assim, a fazer prova do domínio.

Então, para garantir que o autor seja dispensado da prova da propriedade, a alegação de domínio não impedirá a concessão da proteção possessória pleiteada pelo autor. Nessa parte, a teoria de Ihering não foi seguida à risca pelo Código Civil de 1916, que, embora tenha positivado a regra em seu artigo $505,{ }^{231}$ dispondo que a alegação de domínio não obsta a proteção da posse, contraditoriamente proibiu a proteção da posse a quem evidentemente não é proprietário, o que deu margem à criação jurisprudencial e inclusive à edição de súmula pelo Supremo Tribunal Federal ${ }^{232}$ nesse sentido, e previsão semelhante constou da redação originária do artigo 923 do Código de Processo Civil de 1973. Contudo, com a revogação da segunda parte do referido dispositivo da lei processual, passou-se a entender que no Brasil não mais seria possível a exceção do domínio, pois uma das poucas alterações trazidas pelo Código Civil de 2002 em matéria possessória foi a do artigo 1.210, § 2. ${ }^{\circ}$, que dispõe exatamente que "não obsta à manutenção ou reintegração na posse a alegação de propriedade, ou de outro direito sobre a coisa” - tema que será adiante abordado com maior profundidade (item 4.9.2).

Nesse sentido, Ihering ainda prevê a possibilidade de um ladrão se valer da proteção possessória e utilizar, assim, um privilégio que seria apenas do proprietário: o direito de obter proteção da posse provando apenas a posse. Entretanto, o autor sustenta que "a facilidade de prova para a protecção possessoria tem em vista vantagens para o

\footnotetext{
231 “Art. 505. Não obsta a manutenção, ou reintegração na posse, a alegação de domínio, ou de outro direito sobre a coisa. Não se deve, entretanto, julgar a posse em favor daquele a quem evidentemente não pertencer o domínio.”

${ }^{232}$ STF, Súmula 487. "Será deferida a posse a quem, evidentemente, tiver o domínio, se com base neste for ela disputada".
} 
proprietário; em regra, só ao proprietario aproveita essa facilidade; falsearia o intuito dessa facilidade admitir-se na acção uma discussão sobre ser ou não ser o autor proprietario”. 233

Por isso, Ihering afirma que "mais vale que um velhaco excepcionalmente partilhe de um benefício da lei, que ver este benefício recusado a quem o merece - isto sómente para excluir o primeiro".

Em resumo, portanto, o que defende Ihering é que a posse, como exteriorização da propriedade, possa ser protegida por meio dos interditos possessórios, não sendo razoável exigir do proprietário, que pretende defender seu bem, a prova cabal da propriedade, bastando, para tanto, a prova da posse. Além disso, para que esse benefício seja garantido, é necessário que possa ser utilizado por todos - já que o juiz não sabe se o autor é proprietário ou um "velhaco" -, e com isso se corre o risco de que dele se valha um ladrão. Justamente por esse raciocínio é que não se admite a alegação de propriedade pelo réu para obstar a concessão da proteção possessória ao autor.

Até esse ponto a teoria de Ihering desenvolvida para explicar o fundamento da proteção possessória é perfeita - muito embora não possa ser transposta para a atualidade a afirmação de que a prova da posse é mais fácil do que a da propriedade, visto que esta era a realidade de uma sociedade arcaica que não dispunha dos registros públicos para os imóveis, questão que será adiante abordada com maior profundidade (item 4.8.2) -, mas não há na obra de Ihering fundamento que justifique perfeitamente a proteção que se confere ao locatário, ao comodatário, ao credor pignoratício etc.

No entanto, o possuidor que está na posição de comodatário, por exemplo, pode propor a ação possessória alegando que é mero possuidor, e admitindo que não é proprietário. Ou seja, se a proteção processual da posse só é concedida para proteger a propriedade, por que nessa situação, em que o autor admite não ser o proprietário, concede-se a proteção? Parece evidente que, nessa hipótese, o que se protege é apenas a posse, e não a propriedade, e, com isso, ao menos nesse caso a proteção possessória não existe em função da propriedade, o que quebra a regra sustentada por Ihering.

${ }^{233}$ IHERING, Rudolf von. O fundamento dos interditos possessórios, p. 94. 
É possível, como destacou Ihering, que se conceda a proteção possessória a um ladrão, pois o juiz, sem saber se o autor da demanda possessória é proprietário ou ladrão, não pode exigir a prova da propriedade, sob pena de suprimir o benefício de todos. Então, admite-se o risco de conceder a proteção da posse a um ladrão para que não se permita pôr em dúvida a propriedade do autor.

Entretanto, em relação ao comodatário, por exemplo, não há dúvida de que ele não é o proprietário; o possuidor que pede a proteção da posse na qualidade de comodatário admite que não é proprietário, e que é apenas um possuidor, e mesmo assim tem direito aos interditos. Aliás, é possível inclusive que se conceda a proteção possessória no processo movido pelo possuidor direto (locatário, por exemplo) contra o proprietário, o que torna inquestionável que o fundamento dessa proteção é, precipuamente, a posse.

Portanto, ousa-se discordar de que a proteção da posse seja um mero postulado da propriedade, pois, ao menos na situação ora narrada, o que se protege com os interditos é a posse, e não a propriedade. Nesse passo, considerando-se essa situação não explicada por Ihering de forma satisfatória, e levando em conta, ainda, a posição de destaque que por vezes a posse assume em relação à propriedade em relação à proteção processual, mostrase mais adequada e realista a teoria absoluta da posse, que a desvincula da propriedade por meio de uma análise sociológica do fenômeno possessório. ${ }^{234}$

Diz-se que a posse assume posição de destaque em relação à propriedade no tocante à facilidade de sua proteção, primeiro porque na própria teoria de Ihering a proteção da posse é apresentada como facilitador da proteção da propriedade, e segundo porque tradicionalmente se dispensa um procedimento especial para as ações possessórias.

234 “Jhering aprofundou a distância entre a noção jurídica de posse e os elementos da realidade fática ao conceber a posse como ato que exprime a visibilidade da propriedade, embora a sua teoria se pretenda crítica em relação a de Savigny. A posse é reconhecida fato relevante para o direito na proporção em que o ato de apropriação da coisa que a caracteriza possa ser equiparado ao que poderia ser praticado pelo proprietário. Para Pontes de Miranda, a teoria objetiva não é abrangente o suficiente para contemplar toda a extensão do estado de fato próprio da posse, embora reconheça a utilidade da construção teórica de Jhering para o aperfeiçoamento da moderna noção de posse” (OLIVEIRA, Francisco Cardozo. Hermenêutica e tutela da posse e da propriedade, p. 89). "O que se verifica é que a posse é protegida, e deve ser protegida por si mesma, independentemente de qualquer outra consideração. O possuidor deve ser protegido pelo simples fato de possuir, por isso só que possui, qualquer que seja a origem da sua posse” (REZENDE, Astolpho. A posse e sua protecção, v. 1, p. 47). 
Note-se que, para pleitear a proteção da propriedade, por meio da denominada ação reivindicatória, o autor, caso queira obter uma liminar, deverá recorrer à regra da antecipação da tutela disposta no artigo 273 do Código de Processo Civil, ou seja, deverá comprovar os requisitos da verossimilhança e do risco de dano irreparável ou de difícil reparação (urgência). Já para proteger a posse violada há menos de ano e dia, o autor utilizará o procedimento especial do Código de Processo Civil para obter uma liminar, e para tanto deverá comprovar apenas os requisitos do artigo 927, sendo dispensado de comprovar a urgência do provimento requerido. Ou seja, embora a natureza de ambas as decisões liminares (a do procedimento ordinário e a do procedimento especial) seja antecipatória satisfativa, para a proteção da posse contra "força nova" não se exige o requisito da urgência, enquanto para a proteção da propriedade tal requisito é indispensável, o que demonstra que a proteção processual da posse assume posição de destaque em relação à proteção da propriedade - questão a ser aprofundada adiante (item 4.8.2).

Conclui-se, portanto, que a posse, como direito que é, deve ser protegida por si só, sem que, para tanto, seja necessário vinculá-la à propriedade, como se desta fosse mero apêndice. $^{235}$

Contudo, admitida a assertiva de que a posse, como direito que é, deve ser protegida por si só, e não com o fim exclusivo de proteção do direito de propriedade, é possível ainda apontar os malefícios que se busca evitar com a proteção da posse, isto é, a violência contra o possuidor, a perturbação da paz social, o atentado à ordem jurídica e até mesmo a violação ao direito de propriedade.

É certo que se podem atribuir diversas causas para a proteção da posse. Pode-se afirmar, sim, que a proteção da posse facilita a proteção da propriedade, não sendo esse, porém, o seu único e exclusivo fundamento, pois, como já se asseverou, a posse pode ser a exteriorização da propriedade, a sua parte visível, mas não é apenas isso, já que existe por si só, independentemente da propriedade. Pode-se proteger a posse para manter a

\footnotetext{
235 “A razão da proteção possessória nasce e se encerra na finalidade existencial da própria posse, podendo ser mensurada pelo grau de normalidade do poder fático e através de um critério finalístico, via de regra social e econômico. O objetivo da tutela é permitir que o bem realize a sua perfeita, adequada e tranquila destinação socioeconômica, em benefício do titular do poder fático e dentro de um determinado contexto social” (FIGUEIRA JR., Joel Dias. Liminares nas ações possessórias, p. 67).
} 
integridade do possuidor, para protegê-lo da violência do usurpador, mas igualmente não pode ser esse o único fundamento para tal proteção, dado que, em muitos casos, protege-se a posse por meio dos interditos sem mesmo ter havido violência, como ocorre no esbulho que origina a posse precária.

Ocorre, ainda, de a proteção da posse ter também como objetivo a garantia da ordem jurídica e da paz social, mas, como bem observou Cláudia Cimardi, esses fundamentos "são verdadeiros alicerces do sistema jurídico, e explicam não só o porquê da defesa da posse, pois motivam a proteção legal de vários outros interesses”.

Ou seja, o que se denomina "fundamento" talvez possa ser dividido em direito tutelado e consequências prejudiciais que se pretende evitar com a tutela. Qual o fundamento da proteção do direito de crédito? Primeiro, objetiva-se a proteção do direito de crédito, a sua satisfação, mas, sem prejuízo disso, pretende-se, evidentemente, conferir segurança à circulação de dinheiro, evitando-se o exercício arbitrário das próprias razões e consequentemente a violência. Da mesma forma, enquanto a proteção possessória tem por objeto a posse, tem também como objetivo evitar os malefícios mencionados.

Por todos esses motivos é que o sistema jurídico concede a proteção possessória para garantia da situação da posse ao seu titular, mas também para protegê-lo de injustiças e para manter a ordem jurídica e a paz social. Um motivo não exclui o outro e, considerados em conjunto, fundamentam a proteção da posse. Sendo assim, mostra-se acertada a afirmação do autor italiano Roberto de Ruggiero, que entende ser possível “cumular vários motivos, porque umas vezes por outras concorrem para explicar e justificar a tutela concedida à posse", ${ }^{236}$ muito embora o mesmo autor manifeste sua predileção pela teoria da exteriorização da propriedade de Ihering, com o que não se concorda. Protege-se a posse - por si própria, e não exclusivamente a propriedade -, portanto, em razão de seus efeitos gerados no mundo jurídico, de modo a permitir que o bem atinja com segurança a sua finalidade social e econômica. ${ }^{237}$

\footnotetext{
${ }^{236}$ RUGGIERO, Roberto de. Instituições de direito civil, v. 2, p. 619.

${ }^{237}$ FIGUEIRA JR., Joel Dias. Liminares nas ações possessórias, p. 67.
} 


\subsection{Formas de proteção da posse}

A defesa da posse pode ser concedida por diversos meios, todos previstos no nosso ordenamento jurídico, que podem ser agrupados, segundo Cláudia Cimardi, em medidas judiciais e extrajudiciais, ${ }^{238}$ ou, em outras palavras, "quer pela defesa direta, permitida pela lei, quer por intermédio das ações possessórias”. 239

A autotutela, prevista no artigo 1.210, § 1. ${ }^{\circ}$, do Código Civil, representa exceção à vedação do exercício arbitrário das próprias razões, ${ }^{240}$ tipificado como crime no artigo 345 do Código Penal. Implica a permissão legal para que o possuidor, turbado ou esbulhado, mantenha ou recupere a coisa por força própria, podendo repelir, por meio de uma reação legítima e proporcional, qualquer ofensa à sua posse.

Pode-se também dispor de meios judiciais para afastar qualquer agressão à posse, caso não seja possível o desforço. A proteção pela via judicial pode ser concedida por meio de inúmeras medidas, que terão como objeto a proteção da posse, direta ou indiretamente, mas com alguma variação em relação ao fundamento.

Logo, afirma-se na doutrina que são ações possessórias típicas, ou consideradas estritamente, aquelas denominadas de interditos possessórios, quais sejam a reintegração de posse, a manutenção de posse e o interdito proibitório, e que lato sensu, ou atípicas, seriam os demais remédios processuais que não têm como objetivo único e exclusivo a proteção da posse, tampouco a têm como fundamento exclusivo.

Conclui-se, portanto, que é possível classificar a defesa da posse em três espécies, quais sejam o desforço físico imediato, as ações possessórias típicas e os outros remédios que, embora indiretamente protejam a posse, não têm nela o seu único e exclusivo fundamento. ${ }^{241}$ A esses meios de proteção da posse João Batista Monteiro atribui as

\footnotetext{
${ }^{238}$ CIMARDI, Cláudia Aparecida. Proteção processual da posse, p. 68.

${ }^{239}$ RODRIGUES, Silvio. Direito civil. v. 5. Direito das coisas, p. 52.

240 “Trata-se de forma excepcional de fazer justiça pelas próprias mãos. Fora das situações acima expostas, aquele que sofre restrição ao direito de posse deve valer-se do Poder Judiciário para a reparação, o que se dá por meio das ações de reintegração, manutenção ou de interdito proibitório” (DESTEFENNI, Marcos. Curso de processo civil, v. 3, p. 380).

${ }^{241}$ GRECO FILHO, Vicente. Direito processual civil brasileiro, v. 3, p. 273.
} 
denominações “autotutela”, “heterotutela” (os remédios possessórios) e “ações afins dos remédios possessórios”, respectivamente. ${ }^{242}$

\subsubsection{Autotutela}

Sabe-se que nas fases primitivas da civilização não existia um Estado suficientemente forte para repelir as condutas irregulares dos homens e impor o direito mesmo que contra a vontade destes, e por isso aquele que pretendesse obter algo e encontrasse a resistência de outrem teria de conseguir por meios próprios, com sua própria força; é o que se convencionou denominar “autotutela”. Com o fortalecimento do Estado, porém, passou-se a vedar a autotutela como regra, devendo ser submetidos ao poder do Estado os conflitos para que, por meio da jurisdição, seja aplicado o direito com o objetivo de solucionar as controvérsias.

Todavia, "apesar da enérgica repulsa à autotutela como meio ordinário para satisfação das pretensões em benefício do mais forte ou astuto, para certos casos excepcionalíssimos a própria lei abre exceções à proibição”, ${ }^{243}$ sendo exemplo dessas exceções o desforço imediato.

O desforço está previsto no artigo 1.210, § 1. ${ }^{\circ}$, do Código Civil, que, mantendo a essência da norma do artigo 502 do Código revogado, condensou sua redação regulamentando que “o possuidor turbado, ou esbulhado, poderá manter-se ou restituir-se por sua própria força, contanto que o faça logo”. Dispõe ainda o mesmo dispositivo que “os atos de defesa, ou de desforço, não podem ir além do indispensável à manutenção, ou restituição da posse”.

Tem-se, portanto, dois requisitos cumulativos para que seja autorizada e considerada legítima a autotutela: um de natureza temporal, que impõe ao possuidor uma reação imediata ${ }^{244}$ e com força própria, e outro relativo ao modo como se a exerce,

\footnotetext{
${ }^{242}$ MONTEIRO, João Batista. Ação de reintegração de posse, p. 49-51.

243 DINAMARCO, Cândido Rangel; GRINOVER, Ada Pellegrini; CINTRA, Antônio Carlos de Araújo. Teoria geral do processo, p. 35.

244 “Quer se trate de turbação, quer de esbulho, a defesa deve realizar-se na própria ocasião em que se realiza o ataque, ou pelo menos no mesmo dia, havendo apenas o intervalo de tempo necessário para o possuidor se armar ou ir buscar auxílio à mais própria povoação, quando não haja pessoas que, presenciando o fato,
} 
devendo a reação ser proporcional à agressão, a fim de que o uso da força seja moderado e sem excessos, bastando que o ato seja capaz de repelir a ofensa. Com isso, “o abuso, quer temporal, quer quanto aos meios usados na autodefesa, torna a conduta ilícita”. 245

Dessa forma, como bem observou Silvio Rodrigues, a reação tardia mais se assemelha à vingança, e pode configurar nova agressão em vez de simples defesa pessoal. ${ }^{246}$ Vale dizer que, para que o possuidor possa se utilizar da defesa de mão própria, é imprescindível que a reação ocorra logo após a turbação e o esbulho, pois, "passadas a oportunidade e conveniência da autodefesa, cabe ao sujeito recorrer às vias judiciais, sob pena de praticar ilícito penal”. 247

Deve-se atentar, ainda, para a proporcionalidade da reação, que não apenas deve ser minimamente suficiente para repelir a agressão, como também deve respeitar os valores em jogo na disputa da posse. A ofensa à posse não pode ser repelida pela força própria do possuidor a qualquer custo, com sacrifício da vida do ofensor.

Não há na lei critérios que definam quais meios podem ser empregados no exercício da autotutela, mas, assim como na legítima defesa, a reação deve ser proporcional à ofensa, sob pena de o excesso acarretar a responsabilização civil e criminal daquele que pretendia se defender. Nesse sentido,

[...] à luz dos valores constitucionais, não se pode considerar legítima a autodefesa de bens patrimoniais com sacrifício da integridade psicofísica do agressor [...] para a apreciação da legitimidade da autodefesa, juízo de proporcionalidade deverá ser efetuado pelo magistrado, levando em conta a supremacia das relações existenciais sobre as patrimoniais. ${ }^{248}$

É interessante a comparação que inevitavelmente se traça entre o desforço e a legítima defesa do direito penal. Pontes de Miranda denomina a autotutela de "legítima defesa e justiça de mão própria”, o qual afirma ser dirigida contra o ataque atual, turbação

\footnotetext{
se prestem a defende-lo" (GONÇALVES, Luiz da Cunha. Tratado de direito civil. v. 3. Comentário ao Código Civil português, t. 2, p. 670).

${ }^{245}$ LOUREIRO, Francisco Eduardo. In: PELUSO, Cezar (Coord.). Código Civil comentado, p. 1173.

${ }^{246}$ RODRIGUES, Silvio. Direito civil. v. 5. Direito das coisas, p. 53.

247 VENOSA, Sílvio de Salvo. Direito civil. v. 5. Direitos reais, p. 121.

248 TEPEDINO, Gustavo. Comentários ao Código Civil, v. 14, p. 157.
} 
iminente ou “atos perdurantes”. Nesse mesmo sentido, Silvio de Salvo Venosa defende que os princípios norteadores do desforço são os mesmos da legítima defesa, e assevera que haverá legítima defesa quando a posse é ameaçada, e desforço imediato quando a posse é perdida. $^{249}$

No entanto, não se pode confundir a autotutela com a legítima defesa, visto que aquela é mais abrangente do que esta, pois a lei autoriza o possuidor não apenas a agir em legítima defesa para repelir agressões iminentes e atuais, mas também para recuperar a coisa já perdida para o esbulhador, ou seja, autoriza-se o desforço para os atos pretéritos, desde que o "faça logo". 250

A lei não faz distinção entre o possuidor direto e o indireto, o que nos permite concluir que tanto na posse mediata como na imediata o possuidor poderá se valer da autotutela para repelir a agressão. Tampouco impede-se o exercício da autotutela pelo detentor, que, em pé de igualdade com o representante legal, pode defender a posse em proveito de terceiro, a quem deve obediência quanto ao dever de conservá-la.

Da mesma forma, não há qualquer limitação do desforço para a hipótese de posse de má-fé, tanto que, como visto anteriormente, pode o possuidor de má-fé - aquele que tem conhecimento do vício da sua posse - se voltar contra o usurpador por meio dos interditos, não havendo razão para que não possa defender sua posse por meio da autotutela.

\subsubsection{Tutela jurisdicional da posse}

Como visto, a posse pode ser protegida não apenas pelo desforço pessoal, mas também e principalmente por meio da tutela jurisdicional, assim compreendida a "proteção de um direito ou de uma situação jurídica, pela via judicial”. ${ }^{251}$ Por meio do processo, que é o instrumento pelo qual atual o Estado, em sua função jurisdicional, outorga a proteção efetiva ao direito violado ou ameaçado quando vedada a autotutela, sendo a tutela jurisdicional, nesse sentido, a “contrapartida garantida pelo Estado de atribuir os direitos a

\footnotetext{
${ }^{249}$ VENOSA, Sílvio de Salvo. Direito civil. v. 5. Direitos reais, p. 120.

${ }^{250}$ LOUREIRO, Francisco Eduardo. In: PELUSO, Cezar (Coord.). Código Civil comentado, p. 1173.

${ }^{251}$ BEDAQUE, José Roberto dos Santos. Direito e processo: influência do direito material sobre o processo, p. 33.
} 
seus titulares na exata medida em que uma tal atribuição faça-se necessária por alguma razão”. 252

Em relação à tutela jurisdicional da posse, é comum encontrar na doutrina e na jurisprudência a diferenciação entre as “ações possessórias típicas", 253 ou "ações possessórias stricto sensu", ${ }^{254}$ que são aquelas previstas no capítulo V do livro dos Procedimentos Especiais do Código de Processo Civil (artigos 920 a 932), também denominadas por tradição histórica de interditos possessórios, e os remédios de proteção da posse, comumente denominados ações possessórias atípicas ou lato sensu, que "não se destinam única e exclusivamente à proteção possessória, ou que não tenham como possibilidade de fundamento jurídico exclusivamente o direito de posse”. ${ }^{255}$

Seguindo essa classificação, as ações possessórias típicas, ou interditos possessórios, são a reintegração de posse, a manutenção de posse e o interdito proibitório, e são assim consideradas porque se fundamentam exclusivamente no direito de posse e têm como objeto único a sua proteção - ou, mais precisamente, a condenação à obrigação de restituir a coisa ou a obrigação de não fazer consistente em não turbar ou não ameaçar a posse.

Os outros remédios, por seu turno, que podem ter como fundamento e objeto a posse e a sua proteção, porém não exclusivamente, variam nas opiniões dos doutrinadores. Antônio Carlos Marcato faz referência à ação de nunciação de obra nova, aos embargos de terceiro, ao dano infecto e à imissão na posse. Tito Fulgêncio não se refere à ação de dano infecto, mas inclui a de atentado. ${ }^{256}$ Cláudia Aparecida Cimardi insere nesse rol de medidas jurídicas tendentes à proteção da posse todos esses remédios citados por Marcato e Tito Fulgêncio e, ainda, a ação demolitória, a reivindicatória e os embargos de retenção

\footnotetext{
${ }^{252}$ BUENO, Cassio Scarpinella. Curso sistematizado de direito processual civil, p. 311.

${ }^{253}$ MARCATO, Antônio Carlos. Procedimentos especiais. p. 141.

${ }^{254}$ CIMARDI, Cláudia Aparecida. Proteção processual da posse, p. 73.

${ }^{255}$ Idem, ibidem, p. 72.

${ }^{256}$ FULGÊNCIO, Tito. Da posse e das ações possessórias, p. 277.
} 
por benfeitoria. Joel Dias Figueira Jr. ainda faz referência à ação de depósito como outro desses remédios judiciais de proteção da posse. ${ }^{257}$

Apesar de admitir que tais remédios judiciais têm por objeto também, mas de forma transversa, a defesa da situação fática de posse, Joel Dias Figueira Jr. sustenta, com razão, que lhes cabe natureza eminentemente interdital, pois são fundamentadas no direito de propriedade ou no direito obrigacional de devolução da coisa, como é o caso da ação reivindicatória, ou, ainda, na proteção contra atos judiciais de constrição, por exemplo, os embargos de terceiro. ${ }^{258}$

Pode-se concluir, em resumo, que a posse pode ser tutelada por meio de (i) ações possessórias típicas, que têm como exclusivo fundamento o ius possessionis, e, também, por meio de (ii) remédios processuais que não se fundamentam exclusivamente na posse, mas também na propriedade, ou seja, tais remédios podem ser fundados no ius possessionis ou no ius possidendi, e podem, por isso, ser ajuizados "pelo proprietário e não, exclusivamente, por seu eventual possuidor”. ${ }^{259}$

Portanto, denominaremos adiante de "remédios processuais de proteção da posse” aqueles - dotados ou não de procedimento especial - por meios dos quais se pode, de alguma forma, defender a situação da posse, mas que, por não se fundamentarem exclusivamente na posse, e por não terem como objeto exclusivo a sua defesa direta, não podem ser inseridos no grupo daquelas medidas que se convencionou chamar de "ações possessórias típicas”, as quais serão tratadas adiante com maior profundidade no presente trabalho.

É importante destacar que tais denominações são utilizadas para fins meramente didáticos, devendo ser ressaltado que, diversamente do que ocorria no direito romano, em

${ }^{257}$ FIGUEIRA JR., Joel Dias. Liminares nas ações possessórias, p. 78.

${ }^{258}$ Haverá, contudo, certa restrição em relação ao emprego da expressão “ações possessórias lato sensu” ou “atípicas” em relação às ações de reivindicação e de imissão de posse, já que, por serem classificadas como ações petitórias - assim compreendidas aquelas fundamentadas no direito de propriedade -, podem ser incompatíveis com a designação de ação possessória. Contudo, deixando de lado essa questão meramente terminológica, o que importa considerar é que tanto as ações de caráter possessório quanto aquelas denominadas petitórias podem ser inseridas em uma mesma categoria, a dos remédios processuais que têm como objetivo a proteção da posse.

259 MARCATO, Antônio Carlos. Procedimentos especiais, p. 141-142. 
que, “por razões jurídicas e políticas bastante conhecidas, a proteção judiciária não podia ir além do círculo fechado das ações típicas preestabelecidas”, atualmente vivemos em um “sistema de direitos, e não de ações”, ${ }^{260}$ em que a tipicidade é dos direitos, ${ }^{261}$ e não a tutela jurisdicional.

${ }^{260}$ DINAMARCO, Cândido Rangel. Fundamentos do processo civil moderno, v. 1, p. 472.

261 "De um lado isso constitui resultado da influência romana bissecular, enraizada em nossos espíritos e responsável por esse trato sincrético da ação, envolta no direito material. Nem se nega a utilidade prática dessas locuções tradicionais, que transmitem com brevidade e clareza a ideia de quem as emprega; seria muito difícil e complicado dizer no dia a dia ação fundada no direito de propriedade e tendo por pedido a condenação a entregar a coisa, em vez de, simplesmente, ação reivindicatória. Por outro lado, no direito brasileiro o campo é particularmente propício à ideia das ações típicas, em virtude do grande número dos procedimentos especiais existentes no Código de Processo Civil e em incontáveis leis especiais” (DINAMARCO, Cândido Rangel. Fundamentos do processo civil moderno, v. 1, p. 483). 


\section{4 \\ AÇÕES POSSESSÓRIAS TÍPICAS}

\subsection{Contextualização histórica e definição}

Como bem ressaltou Joel Dias Figueira Jr., “os dados e fatos precedentes são elementos valiosos para a compreensão das normas vigentes”, ${ }^{262}$ e, orientado por essa premissa, considera-se necessária uma breve contextualização histórica sobre a proteção da posse por meio dos interditos, de modo a auxiliar na compreensão e definição do sistema atual das ações possessórias típicas, e tal análise deverá complementar aquela já deduzida no presente trabalho em relação ao conceito de posse ao longo dos tempos.

Nesse passo, importa frisar que as denominadas ações possessórias descendem originariamente dos interdictos possessórios do direito romano, com algumas modificações impostas pelo direito canônico e pelos costumes do direito medieval. ${ }^{263}$

Segundo Astolpho Rezende, a origem dos interditos pode ser atribuída à necessidade de garantir interesses individuais que, embora não dotados de caráter de direito, deveriam ser protegidos contra arbitrariedades. Em razão disso, por faltar a esse interesse o fundamento legal para uma ação, o Pretor usava de seu poder e lançava uma ordem ao ofensor, ou seja, os interditos apareceram como expedientes imaginados pelos Pretores para regular relações que não poderiam ser protegidas por meio da actio. ${ }^{264}$

Como já se mencionou anteriormente (item 2.1), é controvertida a origem da proteção possessória no direito romano, pois alguns autores defendem que teria decorrido da necessidade de defesa daqueles que ocupavam o ager publicus, área insuscetível de aquisição dominial, e outros, dentre os quais se encontra Ihering, sustentam que essa proteção teria se originado “na faculdade que tinha o pretor de, nas ações de reivindicação,

\footnotetext{
${ }^{262}$ FIGUEIRA JR., Joel Dias. Liminares nas ações possessórias, p. 107.

263 REZENDE, Astolpho. A posse e sua protecção, v. 1, p. 438.

${ }^{264}$ Idem, ibidem.
} 
até a sentença final, atribuir a uma das duas partes litigantes a posse provisória da coisa litigiosa, posse essa que ele, se necessário, tutelava com interditos”. 265

Sabe-se que o pretor não decidia diretamente as causas que lhe eram apresentadas, cabendo ao juiz o papel de instruir e julgar. No entanto, a ordem ou proibição contida no interdicto, “em vez de ser notificada ao juiz, como a que era inserta na fórmula de uma ação, era dirigida ao réu”, e somente no caso de descumprimento ou oposição de exceção é que seria nomeado um juiz pelo pretor. ${ }^{266}$

Assim, para evitar que o processamento do feito pudesse gerar violência, o pretor proferia uma ordem provisória, entre os litigantes, atribuindo a um deles a posse da coisa enquanto não houvesse um julgamento definitivo. Portanto, o interdito, tal qual como concebido no direito romano, representava a provisoriedade da ordem proferida em uma situação de urgência (interim dicuntum) entre duas pessoas (inter dictum).

É importante entender que, da mesma forma que se modificou o conceito de posse nas mencionadas fases da história de Roma, os meios judiciais de proteção da posse também se alteravam de acordo com a natureza da relação entre a pessoa e a coisa possessio civilis, possessio ad interdicta e detenção - e o período de evolução do direito romano.

José Carlos Moreira Alves destaca que, na fase pré-clássica, já existiam os interditos possessórios, “não se sabendo ao certo, porém, qual era o mais antigo dos interditos”. 267

No direito clássico, segundo o mesmo autor, os interditos possessórios defendiam a possessio civilis e a possessio ad interdicta, e o detentor podia recorrer à actio iniuriarum contra a turbação do uso da coisa. Nesse período, havia duas espécies de interditos: os interdicta retinendae possessionis causa (interditos para conservação da posse), que se

\footnotetext{
${ }^{265}$ MOREIRA ALVES, José Carlos. Posse. Evolução histórica, p. 62.

${ }^{266}$ REZENDE, Astolpho. A posse e sua protecção, v. 1, p. 439.

${ }^{267}$ MOREIRA ALVES, José Carlos. Posse. Evolução histórica, p. 62.
} 
dividiam em interdito uti possidetis e interdicto utrubi, ${ }^{268}$ e os interdicta recuperandae possessionis causa (interditos para recuperação da posse), que os romanistas modernos dividem em interdito unde vi, interdito de precario e interdito de clandestina possessione, os quais tinham por objetivo repelir os atos de violência, precariedade e clandestinidade, respectivamente. ${ }^{269}$ Tanto no interdicta retinendae possessionis causa como no interdicta recuperandae possessionis causa não se admitia a alegação de propriedade (exceptio domini) por parte do réu como defesa.

Não havia, portanto, o interdito recuperandae possessionis causa para as coisas móveis, mas, apesar disso, o possuidor não ficava sem defesa possessória, que poderia ser obtida pela eficácia recuperatória do interdicto utrubi.

No período pós-clássico, “contribuições imperiais vieram combater a violência, inclusive a usada para a autodefesa, estabelecendo penas privadas para os esbulhadores da posse”. ${ }^{270}$ A mais importante dessas contribuições foi editada em 389 d.C., sobre a qual pairam inúmeras divergências na doutrina, tanto em relação à extensão ou não da proteção às coisas móveis quanto no que se refere ao seu caráter possessório, negado por aqueles que defendem o caráter penal ou petitório.

Em seguida, ainda na fase pós-clássica, a implantação da extraordinaria cognitio e o desaparecimento do processo fizeram com que os interditos se transformassem em ações comuns, caracterizadas pelo processo rápido e sumário, tendo sido conservada, entretanto, sua denominação. ${ }^{271}$

${ }^{268}$ A posse dos bens imóveis era protegida por meio do interdito uti possidetis, ao passo que para a defesa da posse de bens móveis deveria o possuidor se valer do interdictum utrubi, que inicialmente era utilizado para a manutenção da posse de escravos. Em ambos os casos não se tutelava a posse violenta, clandestina ou precária.

269 "E invero la tutela interdittale possessória è apprestata non soltanto per difendere il possesso attuale, bensì, a seconda dei casi, anche per recuperare il possesso perduto, oltreché per acquisirlo ex novo" (SACCO, Rodolfo. Enciclopedia del Diritto, v. 34, p. 462).

${ }^{270}$ MOREIRA ALVES, José Carlos. Posse. Evolução histórica, p. 70.

271 "Desde que, porém, em virtude do predomínio da autoridade imperial, o processo formulário foi substituído pelo extraordinário, os interditos perderam a sua razão de ser, e se confundiram com as ações, conservando apenas a sua peculiar denominação" (RIBAS, Antonio Joaquim. Da posse e das ações possessórias, p. 184). 
No direito justinianeu, houve várias inovações no tocante à tutela possessória: a retinendae possessionis causa perdeu sua eficácia recuperatória e, por conseguinte, o possuidor de coisa móvel perdeu a proteção possessória contra o esbulho; a detenção passou a ser protegida pelos interditos possessórios em caso de violência; quanto aos interditos recuperandae possessionis causa, o unde vi podia ser utilizado até um ano após o desapossamento, e o desapossado era protegido mesmo que sua posse tivesse se iniciado por ato de violência, clandestinidade ou precariedade, o que mostra a tendência dessa época de combater as formas de autodefesa.

Refere-se a doutrina, ainda, a uma outra classe de interditos, o interdicta adipiscendae possessionis, que se destinava à aquisição da posse. Controvertem os escritores, entretanto, em relação ao caráter possessório desse interdito, por se considerar que somente poderia ser possessório aquele que tem a posse como objeto, o que não ocorre na situação em que se pretende adquiri-la. ${ }^{272}$ Nesse sentido firmou-se o entendimento de Savigny, ${ }^{273}$ e em sentido contrário o de Ihering, para quem esse interdito apresenta as mesmas características do interdicto retinendae possessionis, o que sustentou por considerar que tanto neste quanto naquele caso a posse seria o objeto da pretensão, e não o seu fundamento. ${ }^{274}$ Vale notar que esse interdito, cujo objetivo é a aquisição da posse, pode ser comparado atualmente com a denominada ação de imissão de posse ou, ainda, com a ação de reivindicação, as quais não estão inseridas na categoria das ações possessórias típicas.

272 "Distingue in proposito la giurisprudenza scolastica del Principato tra interdicta adipiscendae, retinendae e recuperandae possessionis (cfr. Gai 4, 142-143; Paul. D. 43, 1, 2, 3): alla prima categoria sono ascritti iterdetti disparati, quali il Salvianum e il quorum bonorum (cfr. Gai 4, 142-143; Paul. D. 43, 1, 2, 3, cit.: adipiscendae e recuperandae possessionis sono qualificati gli interditti quem fundum e quam hereditem, concessi in sede rispettivamente di vindicatio di immobili e di hereditatis petitio, in Ulp. Frg. Vind. 4) estranei come tali alla tutela del possesso; alla seconda i due interditti uti possidetis e utrubi (v. Gai 4, 148), che peraltro sono utilizzati sin da antico, come vedremo in seguito (v. Infra, $\S 9$ ), anche funzione recuperatoria; alla terza l'unde vi e il vi armata (v. Gai 4, 154-155; Paul. D. 43, 1, 2, 3, cit.); mentre non risulta documentato nelle fonti línserimento, nella tripartizione in parola, degli interdetti de clandestina possessione e de precario” (SACCO, Rodolfo. Enciclopedia del Diritto, v. 34, p. 462).

273 “....] pero cuando se trata de interditos que tienen por objeto la adquisición de la posesión (interdicta adipiscendae possessionis), el demandante no pretende no poseer actualmente ni haber tenido jamás la posesión. Sin embargo, se podían imaginar dos modos de reducir estos interdictos a las mismas ideas fundamentales que las mismas acciones posesorias” (SAVIGNY, M.F.C. de. Tratado de la posesión, p. 241).

${ }^{274}$ IHERING, Rudolf von. O fundamento dos interditos possessórios, p. 61. 
Apesar de originadas dos interdictos do direito romano, as nossas ações possessórias, que já eram admitidas no direito português, resultaram também da influência dos direitos canônico e germânico, "afeiçoados, os três, pela prática dos tribunais e glosas dos praxistas”. ${ }^{275}$ E nesse contexto histórico é que se formaria o direito do reino português, que sofreu influência “dos costumes germânicos, trazidos pelos visigodos; dos direitos canônico e romano, que mais se acentuarão a partir de meados do século XIII; dos elementos hebraico e mulçumano, que em considerável número habitavam a península”. 276

Do direito germânico medieval veio a posse de ano e dia, originária do instituto da Gewere - que trataremos com maior profundidade adiante, no tópico destinado às liminares nas ações possessórias (item 4.8.1) -, que nas Ordenações assumiu a função de viabilizar um procedimento mais célere para a defesa processual da posse.

Quanto ao direito canônico, embora tenha se valido das fontes romanas, trouxe modificações relevantes no campo das possessórias, em vista da orientação de proteger a posse contra toda e qualquer violência.

Inaugurou a Igreja o remédio da exceptio spolli em meados do século IX, destinado ao bispo que, expulso de sua sede, pretendesse retomar seu posto e seus bens; “essa actio spolli não era mais do que o interdicto recuperandae possessionis, unde vi, do direito de Justiniano, consideravelmente ampliado”. ${ }^{277}$ Assim, Astolpho Rezende destacou a influência do direito canônico na formação do direito lusitano lembrando que, nas Ordenações, em vez do interdicto de vi do direito romano, adotou-se a actio spolli do direito canônico, dando-se à violência ou ao esbulho o nome de "força", e às ações os nomes de "ação de força nova turbativa”, que correspondia ao interdicto uti possidetis do direito justiniano, e “ação de força nova espoliativa”, originária da actio spolli (ação de esbulho) do direito romano.

Além disso, o direito canônico alargou as noções de posse ao considerar que, “recaindo sobre o solo, recaía também sobre a jurisdição a ele relativa e os respectivos

\footnotetext{
${ }^{275}$ REZENDE, Astolpho. A posse e sua protecção, v. 2, p. 7.

${ }^{276}$ AZEVEDO, Luiz Carlos de. Introdução à história do direito, p. 131.

${ }^{277}$ REZENDE, Astolpho. A posse e sua protecção, v. 1, p. 460.
} 
direitos”. E assim, evoluiu-se para a ideia de que "os direitos que constituem o estado das pessoas e as obrigações podem ser objeto de posse ou quasi posse”, 278

Na fase das Ordenações do Reino, vigoraram, segundo José Carlos Moreira Alves, ${ }^{279}$ os interditos recuperandae possessionis causa e retinendae possessionis causa, que abrangiam inclusive os direitos pessoais. Reproduziu-se nas Ordenações Afonsinas (livro III, título 52$)^{280}$ a primeira menção a uma ação possessória que se assemelhava a esses interditos romanos. O título 53 do mesmo livro dispõe que o juiz deve proceder sumariamente se houver força nova ("Que em feito de força nova proceda sumariamente sem ordem do juízo”), dando ao “demandador” uma proteção efetiva e rápida contra o esbulhador. Pode-se concluir, pela leitura deste título, que havia um procedimento especial para estes feitos, que deveria ser o mais breve possível, sem as dilações dos outros feitos. $^{281}$

Nas Ordenações Filipinas, de 1603, dispôs-se no título 58 do livro 4. ${ }^{\circ}$ que,

[...] se alguma pessoa forçar, ou esbulhar outra da posse de alguma casa, ou herdade, ou de outra possessão, não sendo primeiro citado e ouvido com sua justiça, o forçador perca o direito que tiver na coisa forçada, de que esbulhou o possuidor, o qual direito será adquirido e aplicado ao esbulhado, e lhe seja logo restituída a posse della. ${ }^{282}$

Apesar das alterações trazidas na segunda metade do século XVIII com o advento do Alvará de 9 de novembro de 1754 e do Assento da Casa da Suplicação de 16 de fevereiro de 1786, como em relação ao reconhecimento da transmissão da posse aos herdeiros, nada foi alterado no campo das ações possessórias.

\footnotetext{
${ }^{278}$ RIBAS, Antonio Joaquim. Da posse e das ações possessórias, p. 222.

${ }^{279}$ MOREIRA ALVES, José Carlos. Posse. Evolução histórica, v. 1, p. 330.

280 Título LII. “Que o Citado por força nova responda logo a Ella sem havendo outro prazo”.

“El Rey Dom Affonso o Terceiro da Louvada Memória em seu tempo fez Ley, per que estabeleceo, e hordenou, que se algum fosse citado principalmente por força nova, a saber, ante que fosse passado anno e dia, des que a força fosse feita, que tal como esse deve loguo responder ao que contra elle he dito sobre a dita força, sem avendo outro algum prazo pêra responder a ello [...].”

281 “[...] façam as ditas demandas as mais breves que poderem: assy, como quer que nos outros Feitos devam ser dadas muitas dilaçoees, em esse dê huuma, e seja peremtoria” (Fonte: site do Instituto de História da Universidade de Coimbra - disponível em: <http://www1.ci.uc.pt/ihti/proj/afonsinas/l3p178.htm>).

282 REZENDE, Astolpho. A posse e sua protecção, v. 2, p. 182-183.
} 
No Brasil, o Código Civil de 1916 revogou expressamente as Ordenações, alvarás, decretos, leis usos e costumes que até então regulavam as matérias de direito civil. Com isso, a posse e sua proteção processual passaram a ser reguladas pelo Código Civil de 1916. Clóvis Beviláqua, observando que “a maioria dos Códigos Civis não se ocupam dos interditos possessórios, por ser matéria processual”, justificou a previsão dessa norma no Código Civil em razão da "íntima ligação existente entre a posse e a sua proteção”. 283 Segundo o autor do Código Civil de 1916, “se, no Brasil, se entregasse aos Códigos processuais a matéria dos interditos, teríamos, dispersando os elementos da teoria possessória, tornado muito precária a sua firmeza”. 284

Como bem observou Joel Dias Figueira Jr., ${ }^{285}$ o Código Civil de 1916, influenciado pela teoria civilista unitária da ação, acabou por regular a proteção possessória como um dos efeitos da posse, dispondo em seu artigo 499 que "o possuidor tem direito a ser mantido na posse, em caso de turbação, e restituído no de esbulho”, norma de direito processual que foi mantida no artigo 1.210, caput, do Código Civil de 2002.

Aliás, a proteção processual da posse aparece na maioria dos manuais de direito civil como um direito decorrente da posse, um efeito desta. ${ }^{286}$ Ocorre que essa classificação da proteção possessória como efeito decorrente da posse, ${ }^{287}$ embora seja compreensível se analisado o contexto em que foi promulgado o Código Civil de 1916, ou,

${ }^{283}$ BEVILÁQUA, Clóvis. Código Civil dos Estados Unidos do Brasil, v. 1, p. 981.

${ }^{284}$ Idem, ibidem, p. 981.

${ }^{285}$ FIGUEIRA JR., Joel Dias. Liminares nas ações possessórias, p. 125.

${ }^{286}$ São inúmeros os efeitos que, segundo a doutrina, decorrem da posse, variando o número desses efeitos de um doutrinador para outro. Para Clóvis Beviláqua, os efeitos da posse são sete: o direito ao uso dos interditos, a percepção dos frutos, o direito de retenção por benfeitoria, a responsabilidade das deteriorações, o usucapião, inversão do ônus da prova a favor do possuidor, e o favorecimento do possuidor em relação à propriedade, cuja defesa se completa com a posse (BEVILÁQUA, Clóvis. Código Civil dos Estados Unidos do Brasil, v. 1, p. 981.). Savigny reduziu esses efeitos para apenas dois, que são o direito aos interditos e o direito ao usucapião (BARROS MONTEIRO, Washington de; MALUF, Carlos Alberto Dabus. Curso de direito civil. v. 3. Direito das coisas, p. 52). Vicente Ráo atribui à posse o único efeito de permitir o uso dos interditos (RÁO, Vicente. Posse de direitos pessoais, p. 27). No entanto, apesar das divergências sobre quais são os efeitos da posse, é possível encontrar consenso no reconhecimento da proteção possessória como um desses efeitos, o que inclusive está estampado nos artigos 1.210 e 1.211 do Código Civil atual, e nos artigos 499 e 501 do Código anterior.

287 "Entretanto, pode-se elencar como um dos principais efeitos da posse o direito às ações possessórias, através das quais busca-se tutela jurisdicional consubstanciada na proteção da posse, enquanto situação de fato, afastando qualquer tipo de agressão, desde a simples ameaça, à perda completa do poder sobre a coisa” (CIMARDI, Cláudia Aparecida. Proteção processual da posse, p. 129). 
mais precisamente, se consideradas as teorias processuais que imperavam naquela época, mostra-se hoje ultrapassada, visto que não releva o avanço científico do processo.

Embora se pregue que o processo tem íntima ligação com o direito material, é preciso conservar a sua autonomia, o que não significa isolá-lo. É que o direito de ação não pode ser confundido com o direito material, e por isso, como destaca Antônio Carlos Marcato, ${ }^{288}$ parece equivocado afirmar que o direito de usar os interditos é mero efeito da posse. Em verdade, a posse, como situação de fato que é, confere ao possuidor o direito a tal situação, ou seja, o possuidor tem direito a continuar na posse, direito de possuir. Por isso, se houver ofensa à posse, poderá o possuidor buscar a tutela jurisdicional do seu direito violado.

Ao asseverar que não seria conveniente o tratamento da proteção da posse pelos “Códigos processuais”, Clóvis Beviláqua referiu-se aos códigos estaduais, que surgiram a partir da outorga aos Estados, pela Constituição de 1891, da prerrogativa de legislar em matéria de direito processual civil, sendo o primeiro deles o da Bahia, de autoria de Eduardo Espínola, promulgado em 1915. Os Códigos de Processo de São Paulo, promulgado em 1930, do Paraná e do Distrito Federal admitiam apenas como remédios puramente possessórios os três interditos (ação de reintegração, de manutenção e o interdito possessório).

No entanto, logo em seguida entrou em vigor o Código de Processo Civil de 1939, unificando a legislação processual no País. Mantiveram-se, nesse código, as ações de reintegração e de manutenção de posse, o interdito possessório, tendo sido incluída no mesmo Título XIII a ação de imissão de posse.

Entretanto, com o Código de Processo Civil de 1973, o tratamento das ações possessórias foi aprimorado com a inclusão de uma primeira seção (Capítulo V, Título I, Livro IV) destinada às disposições gerais, aplicáveis aos três interditos previstos, e com a exclusão do procedimento especial da ação de imissão de posse, que não constitui medida possessória pura por não ser exclusivamente fundada na posse.

\footnotetext{
${ }^{288}$ MARCATO, Antônio Carlos. Procedimentos especiais, p. 141.
} 
Dessa forma, as ações possessórias típicas, como compreendidas hodiernamente, devem ter como fundamento (causa de pedir) necessariamente a posse, de todo e qualquer gênero, pouco importando se é direta ou indireta, justa ou injusta, de boa-fé ou de má-fé. Embora a posse tenha se iniciado com atos de violência, contrários ao direito e, portanto, ilícitos, sua proteção processual é garantida pelo ordenamento jurídico, pois o que se pretende é evitar a realização de atos arbitrários, ainda que praticados pelo proprietário ou por aquele que tem direito à posse.

Portanto, tais interditos têm como objeto a proteção da posse, seja por meio da reintegração da posse perdida, da manutenção da posse turbada ou, ainda, para afastar a ameaça. Cândido Rangel Dinamarco afirma que se chamam tradicionalmente

[...] ações possessórias as demandas de quem vem a juízo, com fundamento na alegação de uma posse que exerce ou exerceu, pedir tutela jurisdicional relacionada com essa posse - seja para ser mantido nela, ou para ser reintegrado, afastar o risco de perdê-la, ou ainda para impedir atos capazes de prejudicar seu integral exercício. ${ }^{289}$

A escolha da via processual correta para proteção da posse por meio dos interditos depende da intensidade da ofensa, conforme será demonstrado com maior profundidade nos itens que a seguir serão apresentados. Assim, para proteger o possuidor do justo receio de ser molestado em sua posse, prevê o artigo 932 do Código de Processo Civil o interdito proibitório, que constitui uma defesa preventiva contra a simples ameaça de turbação ou esbulho. Já para as concretas agressões à posse, o artigo 926 do Código de Processo Civil dispõe que o possuidor tem direito a ser mantido na posse em caso de turbação e reintegrado na hipótese de esbulho.

Nos capítulos seguintes serão tratadas com maior ênfase as três ações possessórias típicas, com a apresentação dos aspectos principais, como as hipóteses de cabimento de cada uma delas, a causa de pedir, o objeto, as condições da ação, os requisitos da inicial, e a definição do ato de ofensa à posse (esbulho, turbação e ameaça).

${ }^{289}$ DINAMARCO, Cândido Rangel. Instituições de direito processual civil, p. 530. 


\subsection{Reintegração de posse}

Como já mencionado, a ação de reintegração de posse, também denominada pelos juristas “ação de esbulho”, corresponde ao interdicto unde vi - espécie da modalidade interdicta recuperandae possessionis - e à actio spolli do direito canônico, e tem por objeto a recuperação da posse perdida em decorrência de esbulho, que, segundo Guido Arzua, repousa no radical de spoluim, com o significado de despojar. ${ }^{290}$

Dispõe o artigo 1.210 do Código Civil que o possuidor "tem direito a ser mantido na posse em caso de turbação, restituído no de esbulho, e segurado de violência iminente, se tiver justo receio de ser molestado", e regra idêntica se encontra no artigo $926^{291}$ do Código de Processo Civil, a regulamentar o cabimento da ação de manutenção de posse para a primeira situação (turbação), a ação de reintegração de posse para o caso de esbulho e o interdito proibitório para assegurar o possuidor contra a ameaça de violência.

À primeira vista, nota-se o encontro de normas que dificilmente poderiam ser inseridas na categoria de direito civil ou de direito processual, visto que preenchem as "faixas de estrangulamento existentes entre os dois planos do ordenamento jurídico". 292 Daí se permite verificar o aspecto "bifronte”293 de alguns institutos, que representa a íntima relação entre direito material e processual, verificável em menor ou maior grau dependendo da relação jurídica analisada.

É intensa a influência do direito material sobre os institutos relacionados à proteção possessória, a exemplo da possibilidade de concessão de liminar sem o requisito da urgência, desde que comprovadas a posse e a ofensa de menos de ano e dia, da limitação da cognição pela regra do artigo 1.210, § 2. ${ }^{\circ}$, do Código Civil (exceção do

\footnotetext{
${ }^{290}$ ARZUA, Guido. Posse. O direito e o processo, p. 78.

291 “Art. 926. O possuidor tem direito a ser mantido na posse em caso de turbação e reintegrado no de esbulho.”

292 DINAMARCO, Cândido Rangel. Instituições de direito processual civil, v. 1, p. 48.

293 “Institutos bifrontes: só no processo aparecem de modo explícito em casos concretos, mas são integrados por um intenso coeficiente de elementos definidos pelo direito material e - o que é mais importante - de algum modo dizem respeito à própria vida dos sujeitos e suas relações entre si e com os bens da vida. Constituem pontes de passagem entre o direito e o processo, ou seja, entre o plano substancial e o processual do ordenamento jurídico (Calamandrei)” (DINAMARCO, Cândido Rangel. Instituições de direito processual civil, v. 1, p. 46).
} 
domínio), das implicações da posse injusta e da posse de má-fé no processo, entre outros institutos que compõem as denominadas faixas de estrangulamento.

Assim, na ação de reintegração de posse o que se tem é a pretensão à restituição da coisa esbulhada, vale dizer, a reposição do autor na posse do bem perdido pelo esbulho. Nas palavras de Adroaldo Furtado Fabrício, essa ação possessória, “também dita de restituição, objetiva restaurar o desapossado na situação fática anterior, desfeita pelo esbulho". ${ }^{294}$ No mesmo sentido, Pontes de Miranda sustentou que a "pretensão por esbulho exerce-se contra aquele que retira ao possuidor o poder fático, quer se trate de posse única, quer de composse, de posse do todo, ou de posse de parte divisa da coisa, haja, ou não, culpa do esbulhador”, e conclui que “a ação é para a restituição da posse e indenização, se foi perdida, ou se tornou manifesto o dano”. 295

Não constitui objeto da ação de reintegração de posse, tampouco dos outros interditos, a defesa da paz social, pretensão que, se fosse real, poderia legitimar para a sua defesa o Ministério Público, conforme ressaltado por João Batista Monteiro; ${ }^{296}$ o escopo das possessórias é, a ratificar o que já defendemos quanto aos fundamentos da proteção possessória (item 3.1), a posse em si, “a satisfação do interesse particular do possuidor”. ${ }^{297}$

Tito Fulgêncio identifica como “objetivo capital” da ação de reintegração de posse o de "restituir a posse ao possuidor" - vale dizer, "tornar a pôr no estado primitivo a posse, que se achava destruída ou perdida” -, e como requisitos essenciais "a posse e seu titular”, assim como "um esbulho dessa posse e seu autor”. ${ }^{298}$ Renan Falcão de Azevedo também faz referência aos “dois pressupostos fundamentais” da ação de reintegração possessória: “a) a existência de uma posse anterior; b) o esbulho desta posse, praticado por outrem, destruindo a relação possessória anterior, que vinculava o possuidor ao objeto”.

O que esses autores denominam requisitos ou pressupostos da ação de reintegração de posse representa, em verdade, a causa de pedir da demanda; tanto a posse

\footnotetext{
${ }^{294}$ FABRÍCIO, Adroaldo Furtado. Comentários ao Código de Processo Civil, v. 8, t. III, p. 415.

295 PONTES DE MIRANDA, Francisco Cavalcanti. Tratado de direito privado, t. X, p. 309.

${ }^{296}$ MONTEIRO, João Batista. Ação de reintegração de posse, p. 73.

297 Idem, ibidem, p. 73.

${ }^{298}$ FULGÊNCIO, Tito. Da posse e das ações possessórias, p. 110.
} 
do autor como a sua perda em decorrência do esbulho configuram a causae petendi. Não se trata de pluralidade de fatos que possam isoladamente constituir a causa de pedir da demanda; ${ }^{299}$ o conjunto dos fatos destacados pelo artigo 927 do Código de Processo Civil é que constitui a causa de pedir, valendo ressaltar que a data do esbulho, prevista no inciso III do referido dispositivo, destina-se à comprovação da força nova, que abrirá caminho ao procedimento especial e permitirá que se conceda a liminar ao autor.

Têm-se como requisitos indispensáveis para a procedência da ação de reintegração de posse, portanto, a posse anteriormente exercida pelo demandante e sua perda em razão do esbulho praticado pelo ofensor. A inocorrência do esbulho e da perda da posse ou a inexistência de posse anterior importará na improcedência da ação de reintegração de posse.

Com isso, aquele que nunca exerceu a posse não pode se valer da ação de reintegração de posse, ${ }^{300}$ isto é, não terá acolhida a sua pretensão de obter a posse do bem. Cite-se o exemplo do adquirente que, após firmar um contrato particular de compra e venda de bem imóvel, pretende se imitir na posse da coisa adquirida contra a vontade do alienante. Se não exerceu a posse, não pode pedir a reintegração, visto que é requisito desta ação possessória típica o exercício da posse, podendo o adquirente dispor, contudo, da ação de imissão de posse, que tem natureza petitória, e não possessória. ${ }^{301}$ Nesse sentido, afirma Cláudia Cimardi que "aquele que jamais exerceu poder de fato sobre a coisa, ou aquele que, por vontade própria, deixou de exercê-lo, intencionalmente, não pode pretender a posse que se encontra em mãos de outrem, através da ação reintegratória”. 302

299 “Cada fato ou conjunto de fatos suscetíveis de produzir, por si só, o efeito jurídico pretendido pelo autor constitui uma causa petendi. Haverá, portanto, pluralidade de causae petendi, sempre que se invoquem dois ou mais fatos ou conjuntos de fatos distintos” (BARBOSA MOREIRA, José Carlos. O novo processo civil brasileiro, p. 17).

300 SANTOS, Nelton dos. In: MARCATO, Antônio Carlos (Coord.). Código de Processo Civil interpretado, p. 2415.

301 “POSSESSÓRIA. Reintegração de posse. Hipótese em que os autores-agravantes jamais tiveram a posse do imóvel. Inadmissibilidade de reintegração a quem nunca teve a posse. Fato incontroverso de que os agravados são os ocupantes do imóvel - Recurso improvido” (TJSP, Agravo de instrumento 012012920.2012.8.26.0000, 23. ${ }^{a}$ Câmara de Direito Privado, Rel. J. B. Franco de Godoi, DJ 15.08.2012).

302 CIMARDI, Cláudia Aparecida. Proteção processual da posse, p. 146. 
Portanto, quem nunca esteve na condição de possuidor não pode lançar mão das denominadas ações possessórias, “ainda que tenha direitos que lhe assegurem o pedido de posse para si”. ${ }^{303}$ Esse entendimento não se coaduna com o sistema que prevalecia no tempo do Código de Processo Civil de 1939, que colocava entre as ações possessórias a ação de imissão na posse, destinada, como já visto, a quem não havia exercido a posse.

Diferente, entretanto, é a situação do adquirente que, embora nunca tenha exercido a posse diretamente e de fato, fez constar no contrato ou na escritura de compra e venda a cláusula constituti, representativa do constituto possessório, que fictamente transfere ao adquirente a posse do bem, colocando o alienante na condição de possuidor em nome alheio, assim como a situação do herdeiro, pelo princípio da saisine, ou do cessionário de direitos possessórios.

Cláudia Cimardi manifesta o entendimento de que, para a hipótese do promitente comprador que tem direito à posse, outorgado no respectivo contrato de compromisso de compra e venda, sua pretensão de exercer a posse somente poderia ser buscada pela via da ação de imissão de posse, e jamais pela ação de reintegração de posse, visto que o repasse ficto da posse ao novo adquirente não teria validade para fins de ajuizamento dos interditos se ele, de fato, nunca exerceu a posse. ${ }^{304}$

Devem-se, entretanto, distinguir duas situações: (i) o contrato de compromisso de compra e venda sem qualquer previsão de transferência da posse e (ii) o contrato de compromisso de compra e venda com cláusula constituti ou qualquer outra cláusula de transferência ficta da posse, ${ }^{305}$ assim como o instrumento particular ou a escritura de

${ }^{303}$ FORNACIARI JUNIOR, Clito. O procedimento das chamadas ações possessórias. In: CAHALI, Yussef Said (Coord.). Posse e propriedade, p. 185.

304 “Não podemos, portanto, concordar com parte da doutrina que entende pelo não cabimento da ação de imissão de posse, por ter o adquirente recebido posse mediante tradição ficta, o que lhe conferiria a pretensão da reintegração de posse. Nada obstante o repasse ficto da posse ao novo adquirente, se este, de fato, nunca exerceu a posse, não poderá invocar a tutela possessória, com fundamento nesse direito (direito da posse), pois justamente este que pretende adquirir de forma inaugural. Para tanto, o adquirente deve formular pretensão à posse com fundamento no direito que a ela é dado respaldo, qual seja, o direito de propriedade” (CIMARDI, Cláudia Aparecida. Proteção processual da posse, p. 77).

305 “Ementa: Reintegração de posse. Imóvel doado pelo município. Invasão do imóvel antes da tomada direta da posse e depois de entregues as chaves. Transferência ficta caracterizada. Possibilidade jurídica do interdito possessório. A assinatura da promessa de doação pelo Município, com entrega das chaves, caracteriza a tradição ficta e a tomada da posse indireta sobre o imóvel, a autorizar a defesa da posse via 
cessão de direitos possessórios. No primeiro caso, o adquirente tem direito à posse, mas não a recebeu sequer fictamente por meio do dito contrato e, por isso, deverá se valer da ação de imissão de posse para exercer seu direito. Já na segunda hipótese houve transferência da posse, o que autoriza o adquirente a utilizar os interditos possessórios.

O constituto possessório é uma forma de aquisição da posse ${ }^{306}$ decorrente de tradição ficta ${ }^{307}$ que, por si só, autoriza o manejo dos interditos possessórios. ${ }^{308}$ Incorrem em erro grosseiro, portanto, aqueles que exigem o efetivo exercício da posse, a apropriação física da coisa, para garantir eficácia e validade à sua transmissão por meio do constitutum possessorium; ${ }^{309}$ se constou do contrato ou da escritura a cláusula constituti ou qualquer

interdito possessório” (TJMG, Apelação 2.0000.00.321557-0/000, Rel. Jarbas Ladeira, j. 08.11.2000, publ. 21.11.2000).

${ }^{306}$ Ementa: "Reintegração de posse. Cláusula de transmissão formal. Constituto possessório. Convenção escritural. Traditio ficta. Ajustamento entre os contratantes em promoção da tradição. Prolongamento da coisa em poder de outrem. Esbulho. Valimento da via possessória. Beligerância avessa ao dolo não induz deslealdade processual. Sentença mantida. Recurso improvido". Trecho do acórdão: "Cuida-se de posse haurida de contrato que explicita cláusula de transmissão formal. Aperfeiçoado o denominado constituto possessório, permite-se o emprego desta via para o exercício do direito, ainda que jamais tenha exercido atos de posse direta sobre o imóvel" (TJSP, Apelação 0010301-24.2008.8.26.0358, 24. ${ }^{a}$ Câmara de Direito Privado, Rel. Sérgio Rui, j. 21.06.2012, publ. 27.06.2012).

307 “A ficta traditio é forma espiritualizada da tradição. Na tradição ficta, a entrega material da coisa é substituída por atitudes, gestos, ou mesmo atos, indicativos do propósito de transmitir a posse, como se verifica com a entrega das chaves na aquisição de uma casa. Para se operar a tradição, basta que o adquirente possa dispor da coisa, ou do direito. Não é necessária a disponibilidade física” (GOMES, Orlando. Direitos reais, p. 64).

308 "Se o autor nunca teve a posse, seu pedido não pode ser possessório; deve ser petitório. Quem nunca teve a posse e precisa que esse direito lhe seja outorgado, deve ingressar com ação reivindicatória, no procedimento ordinário. É preciso atender, porém, ao conceito da expressão 'nunca teve a posse'. A posse se transmite, por ato inter vivos ou causa mortis. Logo, se alguém recebeu, juridicamente, a posse de outrem que a tinha, não está na situação de quem nunca exerceu a posse, porque a recebeu de seu antecessor. Assim, por exemplo, se alguém adquire um terreno, recebe a posse na escritura e, ao ir ao local, encontra um invasor, a sua posse, somando-se à do antecessor, foi esbulhada e a ação é a de reintegração .... (omissis). É o caso, também da reintegração, a hipótese de o vendedor transmitiu a posse na escritura e não a entregar de fato. Nesse momento passou a ser esbulhador. [...] Diferente, porém, é a ação se o vendedor não entrega juridicamente a posse por cláusula contratual, prometendo entregá-la posteriormente e não o faz. Neste caso a ação será petitória de posse, ação de imissão de posse em procedimento ordinário, porque nem juridicamente nem de fato o proprietário teve a posse" (GRECO FILHO, Vicente. Direito processual civil brasileiro, v. 3, p. 223-224).

${ }^{309}$ Voto divergente apresentado pelo Desembargador Fabio Maia Viani no Agravo de Instrumento 1.0352.08.040325-1/001, julgado pelo Tribunal de Justiça de Minas Gerais em 29.05.2008: Consta, é verdade, da escritura pública de compra e venda (fl. 15-TJ), que a transferência do imóvel se deu pela cláusula constituti. Pelo constituto possessório "a posse desdobra-se em duas faces: o possuidor antigo, que tinha posse plena e unificada, se converte em possuidor direto, enquanto o novo proprietário se investe na posse indireta, em virtude" (BARROS MONTEIRO, Washington de. Curso de direito civil Direito das coisas, 34. ed., p. 35). Assim, "o adquirente só adquire a posse indireta, e esta lhe é transferida sem entrega material da coisa, mas pela cláusula constituti” (RODRIGUES, Silvio. Direito civil. Direito das coisas. 28. ed. São Paulo: Saraiva, 2003. p. 41). Na hipótese, contudo, não houve essa transferência 
outra disposição que importe em transmissão da posse, concretizou-se, sim, a sua transferência, a legitimar o adquirente para o ajuizamento das ações possessórias típicas. ${ }^{310}$ Note-se, aliás, que o adquirente pode inclusive ajuizar ação possessória contra alienante, caso este se negue a desocupar o imóvel. ${ }^{311}$ Conforme sustentado por Pontes de Miranda, o constituto possessório “tem eficácia ainda que não valha o negócio jurídico sobre a propriedade; porque somente diz respeito à posse”, 312 pensamento também compartilhado por Gustavo Tepedino. ${ }^{313}$ Discorda-se, por tais razões, do entendimento de que não basta a tradição ficta em contrato para manejo dos interditos possessórios.

Compete ao autor da ação de reintegração, portanto, de acordo com as normas dos mencionados dispositivos legais, a comprovação da sua posse e do esbulho, cuja alegação, para Cláudia Cimardi, é condição de aptidão da petição inicial da ação, enquanto que a demonstração é requisito de acolhimento do pedido da ação possessória. ${ }^{314}$ No mesmo sentido, Arruda Alvim ressalta que tais fatos são requisitos da inicial, que também “deverá

ficta da posse, que não foi desdobrada em direta e indireta, mas sim transferida integralmente. Com efeito, não consta da escritura pública ter o alienante remanescido na posse do bem a outro título - por exemplo, como locatário ou comodatário. De modo que não tem eficácia a cláusula constituti”.

310 “A proteção possessória independe da alegação de domínio e pode ser exercitada até mesmo contra o proprietário que não tem posse efetiva, mas apenas civil, oriunda de título” (REsp 200353/CE, 4. ${ }^{a}$ Turma, Min. Sálvio de Figueiredo Teixeira, DJ 20.02.2003).

311 "Reintegração de posse. Compra e venda de apartamento. 'Cláusula constituti'. Posse direta, mantida com a alienante. Falta de entrega do bem alienado na data avençada. Configuração de esbulho. Na celebração de contrato de compra e venda, com a inserção da cláusula de constituto possessório, para a entrega do apartamento depois de pronto, a alienante permanece com a posse direta, embora transmita ao adquirente o direito de posse. A não entrega do imóvel até a data convencionada por parte do vendedor, em razão da transferência apenas da posse indireta, configura esbulho, elidível por ação de reintegração de posse. Condenação na multa avençada. Indevida. A ausência de pedido expresso na petição inicial não possibilita se condene o alienante impontual em pagar a multa avençada, porque constituiria o julgado em ultra petita. Verba honorária. Elevação. Critérios. A verba honorária, mesmo quando a sentença não é condenatória, deve atender, em regra, aos critérios do desempenho e dignidade profissional e do valor econômico em litígio. Apelação improvida. Recurso adesivo parcialmente provido" (TJRS, Apelação Cível 186072716, Câmara de Férias Cível, Rel. Celeste Vicente Rovani, j. 21.01.1987).

312 PONTES DE MIRANDA, Francisco Cavalcanti. Tratado de direito privado, t. X, p. 208.

313 TEPEDINO, Gustavo. Comentários ao Código Civil, v. 14, p. 129.

314 "Com efeito, dispõem referidos textos legais os elementos de direito material que devem estar presentes na ação de reintegração de posse para que, se alegados, a petição inicial seja considerada apta; e, se demonstrados, seja possível o julgado de mérito favorável ao pedido de restituição da situação anterior ao ato violador. Pode-se, inclusive, afirmar que tais elementos são requisitos, um primeiro momento, de admissibilidade da petição inicial; e, num segundo momento, de acolhimento do pedido da ação possessória” (CIMARDI, Cláudia Aparecida. Proteção processual da posse, p. 143). 
observar aqueloutros estampados nos arts. 282 e 283”. ${ }^{315}$ Entendemos, contudo, que os fatos em questão não devem ser considerados requisitos da inicial da ação de esbulho, mas sim causa que autoriza a procedência da demanda, conforme entendimento já manifestado pelo Superior Tribunal de Justiça. ${ }^{316}$

Não se devem supervalorizar as condições da ação a ponto de reconhecer a falta de interesse processual da ação possessória caso não seja comprovada a posse alegada na inicial. Essa situação, embora se encontre entendimento diverso na jurisprudência, deve gerar, na maioria das vezes, o julgamento de mérito pela improcedência do pedido, visto que a posse exercida pelo autor e o esbulho são exatamente os fatos constitutivos do seu direito, que autorizam, se comprovados, o acolhimento do pedido de reintegração de posse, e não elementos constitutivos das condições da ação.

Sobre o tema, Cândido Rangel Dinamarco leciona que as ações consideradas na lei, como é o caso das possessórias, que contam com procedimento especial, transmitem ao intérprete a falsa ideia de que estariam sujeitas a condições especiais, e que certos requisitos de direito material acabam, por isso, indicados como condição da ação. ${ }^{317}$

O mesmo autor alude às ações possessórias lembrando que, segundo o artigo 927 do Código de Processo Civil, compete ao autor provar a posse, ato de turbação ou o esbulho, o dia em que se deu esse ato e a situação atual, e critica a posição daqueles que veem nesses requisitos as condições da ação, cuja ausência conduziria o autor à carência da ação possessória. ${ }^{318}$

Ainda quanto aos requisitos do artigo 927 do Código de Processo Civil, importa ressalvar que a ausência da prova na inicial sequer poderia dar azo à extinção por falta de interesse processual, visto que são requisitos para a concessão da liminar. Nesse sentido, afirma Adroaldo Furtado Fabrício que, se o autor não os comprova com os documentos da

\footnotetext{
${ }^{315}$ ARRUDA ALVIM; ASSIS, Araken de; ALVIM, Eduardo Arruda, Comentários ao Código de Processo Civil, p. 1852.

316 “Constituem requisitos para a procedência da ação possessória de reintegração a prova da posse da área e do esbulho com a sua perda” (REsp 1.213.518, Min. Ricardo Villas Bôas Cueva, DJ 06.12.2011).

${ }^{317}$ DINAMARCO, Cândido Rangel. Fundamentos do processo civil moderno, v. 2, p. 486.

${ }^{318}$ Idem, ibidem, p. 486.
} 
inicial, ou mesmo na audiência de justificação, “a consequência não é, entretanto, a desestimação da demanda possessória, mas sim e somente a denegação do mandado liminar; é exclusivamente de sua expedição ou não que se cogita nesse estágio”. 319

É muito comum encontrar na doutrina ${ }^{320}$ e na jurisprudência ${ }^{321}$ a afirmação de que, ausentes tais requisitos - posse anteriormente exercida pelo demandante e o esbulho praticado pelo ofensor -, haverá carência da ação possessória por falta de uma das condições da ação: o interesse processual. Não nos parece correto, todavia, generalizar tal entendimento, visto que, em regra, se não alegado ou não comprovado o esbulho, ou se não alegado ou comprovado o exercício da posse pelo demandante antes do esbulho, não terá direito à proteção possessória, vale dizer, não terá reconhecido o direito que viabilizaria a procedência da ação possessória.

Não se trata de carência da ação por ausência de condição da ação, mas sim de improcedência gerada pelo reconhecimento de que o autor não tem direito à proteção possessória. Tem-se, portanto, o que Cândido Rangel Dinamarco denominou de "falsa carência”, 322 pelo que assevera o mesmo autor que "quem não tinha a posse anterior não tem o direito à própria posse - e isso diz respeito diretamente ao mérito da ação possessória”. 323

A consequência dessa discussão não é meramente acadêmica; pelo contrário, importa, na prática, em segurança ao réu, visto que a carência da ação decorrente da

\footnotetext{
${ }^{319}$ FABRÍCIO, Adroaldo Furtado. Comentários ao Código de Processo Civil, v. 8, t. III, p. 484.

320 “Muitas vezes, o autor do pedido nunca foi possuidor e não obteve qualquer transmissão ou sucessão na posse (acessio ou sucessio possessionis). Poderá ter pretensão petitória e legitimidade para ingressar com ação reivindicatória. Entretanto, não terá pretensão possessória. Seu pedido será juridicamente impossível sob o prisma possessória” (MEDINA, José Miguel Garcia; ARAÚJO, Fábio Caldas de; GAJARDONI, Fernando da Fonseca. Processo civil moderno. Procedimentos cautelares e especiais, v. 4, p. 273).

321 “Reintegração de posse. Ausentes os requisitos essenciais para o seu ajuizamento Prévia notificação e esbulho que não foram comprovados - Má-fé, porém, não configurada Carência da ação decretada Recursos não providos” (TJSP, Apelação 0039050-87.2010.8.26.0000, 20ª Câmara de Direito Privado, Rel. Cunha Garcia, j. 16.04.2012).

322 “Os tribunais brasileiros, influenciados pelo vigor da teoria das condições da ação e sua adoção explícita no Código de Processo Civil, são fortemente propensos a tratar como carência de ação alguns casos de ausência do direito do autor perante o réu - nos quais, em realidade, estão julgando a demanda improcedente e, não, inadmissível por falta de alguma das condições da ação” (DINAMARCO, Cândido Rangel. Instituições de direito processual civil, v. 2, p. 326).
}

${ }^{323}$ Idem, ibidem, p. 486. 
ausência de prova da posse possibilitaria ao autor a repetição da mesma demanda, em verdadeira eternização do litígio, ao passo que o julgamento de mérito poria fim à discussão. $^{324}$

Apesar de concordarmos com o posicionamento de Cândido Rangel Dinamarco, é preciso destacar a situação do demandante que, apesar de sequer alegar o exercício anterior da posse na ação de reintegração, tem direito à posse da coisa por força do domínio. Ou seja, o demandante poderia reclamar a proteção da sua posse, mas com fundamento no domínio ou em outro direito sobre a coisa, por meio da ação reivindicatória (art. 1.228, CC) ou da ação de imissão de posse, e não pela via da ação de reintegração de posse, que admite como único e exclusivo fundamento a posse. Nesse caso, quer nos parecer que haveria, sim, carência da ação, por ausência de interesse processual, ou, mais precisamente, de "interesse-adequação", 325 conclusão a que se chega com apoio no conceito doutrinário de interesse processual. ${ }^{326}$

São duas situações, portanto: (a) o autor que propõe ação de reintegração de posse com fundamento somente no seu direito de propriedade, consubstanciado em escritura de compra e venda, sem sequer alegar que exerceu a posse; e (b) o autor que alega ter exercido a posse e sucumbe na ação por não provar tal fato, a exemplo do detentor que

324 “Pelo ângulo do direito material importa identificar a verdadeira sentença de mérito, pois este resultado corresponde exatamente aos objetivos do processo. Dele resulta a formulação da regra concreta para determinada situação de direito material, com eliminação do litígio e pacificação social. Isso em princípio não ocorre com as sentenças de carência, não obstante os efeitos substanciais que elas produzem. Talvez seja correto afirmar que a ausência de uma das condições da ação pode importar solução de uma pequena parcela da situação de direito material controvertida. Mas sua abrangência é bem menor que aquela alcançada pela sentença de mérito propriamente dita” (BEDAQUE, José Roberto dos Santos. Efetividade do processo e técnica processual, p. 260).

325 "Existem dois fatores sistemáticos muito úteis para a aferição do interesse de agir, como indicadores da presença deles: a necessidade da realização do processo e a adequação do provimento jurisdicional postulado. [...] O interesse-adequação liga-se à existência de múltiplas espécies de provimentos instituídos pela legislação do país, cada um deles integrando uma técnica e sendo destinado à solução de certas situações da vida indicadas pelo legislador. Em princípio, não é franqueada ao demandante a escolha do provimento e portanto da espécie de tutela a receber. Ainda quando a interferência do Estadojuiz seja necessária sob pena de impossibilidade de obter o bem devido (interesse-necessidade), faltar-lheá o interesse de agir quando pedir medida jurisdicional que não seja adequada segundo a lei” (DINAMARCO, Cândido Rangel. Instituições de direito processual civil, v. 2, p. 312).

326 “A falta de interesse decorre da não correspondência entre o fato narrado e a tutela pleiteada, que pode ser desnecessária ou inadequada. Será inútil o prosseguimento do processo se a situação descrita na inicial não apontar comportamento de alguém contrário ao que determina o direito material, nem fato apto a modificar situação jurídica” (BEDAQUE, José Roberto dos Santos. Efetividade do processo e técnica processual, p. 260). 
propõe ação de reintegração de posse afirmando que sua posição foi alterada de detenção para posse, sem, contudo, fazer prova dessa alegação.

A primeira situação deve conduzir ao indeferimento da petição inicial e à extinção da ação por ausência de interesse processual ${ }^{327}$ - “interesse-adequação” -, enquanto a segunda deverá atingir o julgamento de mérito, com a improcedência da ação. ${ }^{328}$ Não se pretende aqui defender a teoria da asserção, também denominada prospectação, ${ }^{329}$ segundo a qual a ausência das condições da ação somente poderia ocorrer no início do processo, tampouco utilizar a profundidade da cognição como elemento de distinção entre condições da ação e mérito. ${ }^{330}$

Ocorre que, no primeiro exemplo, o autor sequer alega ter exercido posse, vale dizer, não alega ter direito de posse, mas tão somente o domínio, que poderia fundamentar a “ação petitória”, e com isso fica evidente, já no recebimento da inicial, a inadequação da via eleita. No outro caso, contudo, o autor alega ter exercido posse, e defende o seu direito

327 "Em relação à ação de reintegração de posse, vislumbro que, a despeito da comprovação da propriedade do imóvel controvertido pela empresa Siar Empreendimentos, não houve mínima demonstração de que, em algum momento, exerceu atos de posse, o que se corrobora inclusive pela narrativa dos fatos e documentos acostados pela própria autora da reintegração. [...] Nas ações possessórias, tanto o pedido como a causa de pedir devem ser a posse. Nos casos em que fundada na propriedade, a ação será petitória e não possessória. Ressalto que a análise de eventual propriedade na ação possessória pode ser feita para contribuir na formação da convicção do julgador, fornecendo elementos para reintegrar ou não o autor na posse, mas não pode servir, exclusivamente, como parâmetro para o ajuizamento da ação possessória. Na hipótese em testilha, a causa de pedir é estritamente a propriedade adquirida pela autora por força do contrato de compra e venda. Inadmissível, portanto, o ajuizamento de ação possessória fundada unicamente no domínio [...] Em resumo, não anseia a autora reintegração de posse, mas imissão. Ante o exposto, reformo a sentença para julgar a autora carecedora da ação de reintegração de posse” (TJSP, Apelação 0086475-14.2004.8.26.0100, 17. ${ }^{a}$ Câmara de Direito Privado, Rel. Luiz Sabbato, DJ 27.07.2012).

328 “Apelação cível. Posse (bens imóveis). Reintegração de posse. Contrato de locação indemonstrado. Ausência de posse anterior. As versões trazidas pela autora, na inicial e em seu depoimento pessoal, não se sustentam, porquanto, pela primeira, a prova indica que não houve esbulho, enquanto que, pela segunda, a prova demonstra que não houve posse anterior. Desta feita, improcede a pretensão deduzida de reintegração de posse. Negaram provimento ao apelo. Unânime” (TJRS, Apelação Cível 70026272013, 18. ${ }^{a}$ Câmara Cível, Rel. Elaine Maria Canto da Fonseca. j. 06.09.2012, publ. DJ 11.09.2012).

329 "Se a inexistência das condições da ação, todavia, for aferida só ao final, diante da prova produzida (e não há preclusão nesta matéria, podendo o juiz rever sua anterior manifestação), duas posições podem ser adotadas: para a primeira (teoria da apresentação), mesmo que venha a final, a decisão será de carência da ação; para a segunda (teoria da prospectação), a sentença nesse caso será de mérito.”

330 “[...] a única maneira de distinguir a categoria das condições da ação do mérito é pela profundidade da cognição. Se o juiz, após exame profundo do fato constitutivo afirmado na inicial, conclui pela inexistência dele, julga improcedente o pedido" (BEDAQUE, José Roberto dos Santos. Efetividade do processo e técnica processual, p. 254). 
à reintegração com fundamento na posse, mas ao final não consegue comprovar tal fato. Ou seja, neste último caso, não houve erro na escolha da ação possessória; o autor acreditava - ou alegou falsamente - que havia exercido a posse, e por isso escolheu corretamente a via processual, apesar de ao final ter sido julgada improcedente a demanda por não ter sido provada a alegação de fato da inicial.

Ademais, encontram-se na doutrina e na jurisprudência outros exemplos de carência da ação possessória, como no caso em que se pretende, por meio de ação possessória típica, proteger servidão não aparente cujo título não provenha do possuidor do prédio serviente, ou daqueles de quem este os houver (art. 1.213, CC), defender bens imateriais $^{331}$ e áreas públicas em favor de particular e, ainda, retirar do imóvel residencial o locatário, quando se sabe que a via correta é a da ação de despejo.

Tais regras valem para os três interditos previstos na lei, quais sejam a ação de reintegração de posse, a de manutenção e o interdito possessório - feitas as devidas adaptações em relação a este último ${ }^{332}$-, servindo de elemento distintivo para escolha de uma dessas vias a intensidade da agressão à posse.

O esbulho, ofensa da maior gravidade, desafia a ação de reintegração de posse, porquanto nessa situação o possuidor terá sido alijado da posse de seu bem, vale dizer, teve subtraída sua coisa móvel ou foi retirado de seu bem imóvel, não podendo, por isso, exercer qualquer poder sobre a coisa em razão do ato ilegal. Diversamente ocorre na turbação, em que o possuidor não é privado da sua posse, mas sofre embaraços ao seu pleno exercício. Segundo Nelton dos Santos, “o despojamento da posse configura esbulho; já o embaraço ao exercício da posse caracteriza a turbação". 333

\footnotetext{
${ }^{331}$ MARINONI, Luiz Guilherme; ARENHART, Sérgio Cruz. Procedimentos especiais, p. 104.

332 “Na verdade, não só as regras da Seção II, mas também as da Seção I, em sua maioria, aplicam-se ao interdito proibitório. [...] Já na Seção II, todos os artigos são aproveitáveis, cabendo apenas adaptar-lhes à característica preventiva deste interdito. O que o autor tem de provas, além de sua posse, para fins do art. 927, é a ameaça de turbação ou esbulho, donde emana o "justo receio" (FABRÍCIO, Adroaldo Furtado. Comentários ao Código de Processo Civil, v. 8, t. III, p. 514-515).

333 SANTOS, Nelton dos. In: MARCATO, Antônio Carlos (Coord.). Código de Processo Civil interpretado, p. 2415.
} 
Não é tarefa simples a distinção entre os atos que, na prática, importam em esbulho ou turbação; não é tranquila a qualificação do ato que viola a posse. Conceitualmente, entende-se como esbulho - e aqui se vale do ensinamento de Humberto Theodoro Júnior - “a injusta e total privação da posse, sofrida por alguém que a vinha exercendo”, 334 e quanto ao conceito não há divergência. Tito Fulgêncio explica que o esbulho "é o ato de tomar alguma coisa a alguém contra sua vontade sem legítima autoridade ou direito", 335 e que, aplicado tal significado à posse, importa em injusta privação da posse, em todo ou em parte. Ao tratar da casuística do esbulho, Pontes de Miranda cita como exemplo a conduta daquele que ocupa a casa deixada pelo inquilino, sem permissão de quem a poderia alugar. ${ }^{336}$

A dificuldade surge na prática não apenas pela necessidade de correta qualificação da conduta do ofensor, como também pelo dinamismo dos fatos, visto que, em diversas situações, é estreito o liame entre a turbação e o esbulho. Imagine-se que, em dois imóveis rurais contíguos, o proprietário do imóvel “A” rompa a cerca que divide ambas as áreas, com a finalidade de criar um atalho para encurtar o caminho até a estrada mais próxima, passando por dentro do imóvel "B”. Tal conduta configura uma turbação, pois, embora não prive totalmente a posse do proprietário, pode lhe causar embaraços e limitações. Imaginese, então, que, criado o dito atalho, o proprietário “A” resolva instalar a cerca em lugar diverso, de modo a subtrair parte do imóvel de “B”, integrando-a à sua área. Essa situação, apesar de não representar privação da posse sobre todo o imóvel “B”, caracteriza o esbulho em relação à área subtraída.

Assim, verifica-se, a partir desse exemplo, que as condutas que configuram turbação e esbulho são muito próximas, podendo a agressão de menor potencial evoluir rapidamente para a completa privação da posse, pelo que dispôs o Código de Processo Civil, em seu artigo 920, sobre a fungibilidade das possessórias, tema que será abordado adiante.

\footnotetext{
334 THEODORO JÚNIOR, Humberto. Ações possessórias. Revista Brasileira de Direito Processual, v. 44, p. 104, 1984.

${ }^{335}$ FULGÊNCIO, Tito. Da posse e das ações possessórias, p. 113.

${ }^{336}$ PONTES DE MIRANDA, Francisco Cavalcanti. Tratado de direito privado, t. X, p. 332-333.
} 
O que diferencia o esbulho da turbação, portanto, é a intensidade da ofensa à posse, fator determinante para a correta indicação da causa de pedir e do pedido da demanda possessória.

Não é necessária, entretanto, a violência para configuração do esbulho, ${ }^{337}$ mas tão somente o injusto desapossamento, bastando que o possuidor seja totalmente despojado do poder de exercício de fato sobre a coisa, ${ }^{338}$ ou sobre parte dela. Incumbe ao autor da ação de reintegração de posse, portanto, provar a sua posse e a perda injusta da coisa, o que bastará para a procedência da demanda, sendo dispensável, para esse fim, a presença de violência no ato do esbulho. É certo que o esbulho pode decorrer de violência, mas pode também resultar de ato clandestino ou precário que, de igual modo, subtraem do possuidor a coisa móvel ou imóvel. ${ }^{339}$

Igualmente independe do elemento subjetivo o reconhecimento do esbulho, ou seja, do animus spoliandi; o esbulho ocorre quando o ofensor pratica atos que impedem o exercício da posse de outrem contra a sua vontade, pouco importando se a intenção do ofensor foi a de prejudicar o possuidor. Nesse sentido, considera João Batista Monteiro que “o agente, quando esbulha de boa-fé, age em virtude do erro em que incide [...] a boa-fé não é incompatível com o erro [...] que age de boa-fé o faz por erro de direito ou de fato, que não elimina, mas antes pressupõe, a sua culpa”. 340

Situação diversa, porém, é a do terceiro que recebeu a coisa esbulhada, contra quem somente poderá ser intentada ação de reintegração de posse se tinha conhecimento do vício. Essa é a norma do artigo 1.212 do Código Civil, que, a contrario sensu, impede que seja "intentada” ação de esbulho caso o adquirente tenha recebido a coisa esbulhada sem saber que o era. O esbulhado não poderá “intentar” ação de reintegração de posse,

\footnotetext{
337 “Ação de reintegração de posse. Relação de comodato comprovada. Notificação prévia. Não desocupação do bem no prazo concedido. Esbulho caracterizado, independente de ato de violência do esbulhador. Ação julgada procedente, em parte. Recurso não provido” (TJSP, Apelação 9090790-09.2002.8.26.0000, Câmara de Direito Privado, Rel. Zélia Maria Antunes Alves, DJ 06.07.2011).

${ }^{338}$ VENOSA, Sílvio de Salvo. Direito civil. v. 5. Direitos reais, p. 147.

339 “Com efeito, a lei confere a ação de reintegração diante de uma posse e de um esbulho, sem fazer qualquer distinção, isto é, sem curar de saber se o esbulho é violento ou pacífico” (MONTEIRO, João Batista. Ação de reintegração de posse, p. 123).

${ }^{340}$ Idem, ibidem, p. 127.
} 
segundo a letra da lei, mas terá ao seu dispor, “porém, ação petitória para tal finalidade, fundada no ius possidendi, vale dizer em relação jurídica de direito real ou pessoal que confira direito à posse”. ${ }^{341}$

Ao interpretar o artigo 504 do Código Civil de 1916, correspondente do artigo 1.212 do Código atual, J. M. de Carvalho Santos citou o exemplo do contrato de venda com cláusula de reserva de domínio, em que o comprador, violando o contrato, aliena o bem a um terceiro. Nesta situação, afirma o autor que "não pode o vendedor pedir a reintegração de posse contra o terceiro adquirente, se estava de boa-fé”. 342

É evidente, no entanto, que não será suficiente a mera alegação de ignorância por parte do adquirente de boa-fé para impedir o ajuizamento da ação de reintegração de posse. As circunstâncias do caso concreto é que deverão conduzir o juiz na investigação da boa-fé do terceiro que recebeu a coisa esbulhada, e nesse contexto deve ser observado o dever de diligência do adquirente. Conforme asseverou Gustavo Tepedino,

[...] hão de ser examinadas pelo juiz, para tanto, as condições sociais, culturais e econômicas que circunscrevem o negócio, além da natureza mobiliária ou imobiliária da aquisição, de molde a verificar se o adquirente teria possibilidade de certificar-se do vício que inquinava a posse do alienante. ${ }^{343}$

Dispôs-se no Enunciado 80 da Jornada I Superior Tribunal de Justiça que “é inadmissível o direcionamento de demanda possessória ou ressarcitória contra terceiro possuidor de boa-fé, por ser parte passiva ilegítima, diante do disposto no CC 1212”. Constou, ainda, do referido enunciado que "contra o terceiro de boa-fé cabe tão somente a propositura de demanda de natureza real”. No mesmo sentido, afirma Joel Dias Figueira Júnior que "verifica-se carência da ação por falta de legitimidade passiva no direcionamento de demanda interdital contra terceiro com justo título e boa-fé”. ${ }^{344}$

\footnotetext{
${ }^{341}$ LOUREIRO, Francisco Eduardo. In: PELUSO, Cezar (Coord.). Código Civil comentado, p. 1177.

${ }^{342}$ CARVALHO SANTOS, J. M. de. Código Civil brasileiro interpretado.

343 TEPEDINO, Gustavo. Comentários ao Código Civil, v. 14, p. 166.

${ }^{344}$ FIGUEIRA JR., Joel Dias; FIUZA, Ricardo. Código Civil comentado, p. 1136.
} 
Não nos parece correto, entretanto, tal entendimento, visto que a má-fé do terceiro somente poderá ser constatada no processo judicial, motivo pelo qual não haverá ilegitimidade caso se apure sua boa-fé, mas sim improcedência da demanda, ${ }^{345}$ sendo possível, nesta situação, o ajuizamento de ação real fundada no domínio.

Dessa forma, a ação de reintegração de posse terá como objeto - e por “objeto" deve-se entender a pretensão posta pelo autor da demanda, tema já muito debatido e elucidado pela doutrina alemã ${ }^{346}$ - a recuperação da posse perdida, a restituição da coisa móvel ou imóvel. Embora se possa afirmar que as ações possessórias visam a proteção da posse, ${ }^{347}$ é certo que em cada um dos interditos se busca um provimento de natureza diversa, conforme será demonstrado adiante em item exclusivo.

Na doutrina italiana, Luigi Paolo Comoglio, classificando o esbulho como a privação, total ou parcial, do poder de fato sobre a coisa, assevera que, quando houver esbulho, por meio de violência ou ocultamento - que equivale à clandestinidade -, poderá o titular da posse recorrer ao Judiciário e requerer a reintegração de posse, ${ }^{348}$ nos termos do artigo 1.168 do Código Civil italiano ${ }^{349}$ - sistema muito semelhante ao brasileiro. No

345 "Reintegração de posse. Bem público municipal. Permissão de uso. Abandono do imóvel pelo permissionário. Repasse a terceiro de boa-fé. Inexistência de esbulho. Art. 520, I, do Código Civil. Ação improcedente" (REsp 114215, Min. Barros Monteiro, Quarta Turma, DJ 17.10.2002). No mesmo sentido: "Apelação. Ação de reintegração de posse. Veículo automotor. Autor vítima de estelionato que não toma as mínimas cautelas. Entrega do bem a terceira pessoa não identificada, assinatura em branco do respectivo documento de transferência e aceitação de cheque de terceiro (pessoa jurídica) como forma de pagamento, que posteriormente se constata ter sido objeto de furto ou roubo. Posterior aquisição por terceiro de boa-fé, contra quem a possessória foi ajuizada. Ausência de esbulho. Sentença mantida por seus próprios fundamentos, ora reproduzidos (art. 252 do RITJSP). Precedentes do STJ e STF. Apelo desprovido". Trecho do acórdão: "Trata-se de ação de reintegração de posse [...] julgada improcedente pela sentença” (TJSP, Apelação 0047151-34.2010.8.26.0576, 29. ${ }^{a}$ Câmara de Direito Privado, Rel. Pereira Calças, DJ 17.10.2012).

346 “Al respecto, reina pleno consenso en la doctrina y también en la pratica. Por tal razón, se habla generalmente de pretensión procesal. La pretensión procesal es el objeto litigioso. Trátase de conceptos sinónimos, que pueden sustituirse el uno por el otro o intercambiarse sin dificultad" (SCHWAB, Karl H. El objeto litigioso en el proceso civil, p. 5).

${ }^{347}$ MARCATO, Antônio Carlos. Procedimentos especiais, p. 142.

348 “[...] lo spoglio, tradizionalmente caratterizzato sul piano soggettivo dall'animus spoliandi, identifica ogni consapevole privazione, totale o parziale, delláltrui potere di fatto sulla coisa. [...] quando sia stato violentamente od occultamente spogliato del possesso, può ricorrere al giudice e chiedere la reintegrazione del possesso" (COMOGLIO, Luigi Paolo; FERRI, Corrado; TARUFFO, Michele. Lezioni sul processo civile, p. 76).

349 “Articolo 1168. Chi è stato violentemente od occultamente spogliato del possesso può, entro l'anno dal sofferto spoglio, chiedere contro l’autore di esso la reintegrazione del possesso medesimo. 
mesmo sentido, o autor italiano Michele Zuccalà ensina que o fim específico da ação de reintegração é a repristinação da situação anterior ao esbulho, reconduzindo o possuidor esbulhado na posse da coisa usurpada. ${ }^{350}$ Não é diverso o tratamento das ações possessórias típicas na Espanha, onde também se delimita como objeto destas "una pretensión procesal dirigida a conservar o recuperar la posesión de un objeto cualquiera”, 351 e na Alemanha, cujo sistema igualmente divide as possessórias típicas de acordo com a ofensa à posse, ou seja, esbulho ou turbação, nominando os meios de proteção de "la pretensión por privación” e "pretensión por inquietacións”. 352

\subsection{Manutenção de posse}

Como já sustentado no tópico anterior, variam as formas de ataque à posse, e igualmente os meios processuais para a sua defesa, e tal variação decorre da intensidade da agressão sobre a situação de fato do possuidor. Conforme ensina Adroaldo Furtado Fabrício, “essa gravidade varia de um grau mínimo (simples ameaça, de que o Código trata em seção separada) a um máximo, que é a privação da posse”, estando situada entre os extremos a ofensa de médio grau, que é a turbação. ${ }^{353}$

Sob o aspecto processual, pouca diferença há entre a ação de reintegração de posse e a de manutenção, tanto que o Código de Processo Civil dispensou o mesmo

L'azione è concessa altresì a chi ha la detenzione della cosa (1140), tranne il caso che l'abbia per ragioni di servizio o di ospitalità.

Se lo spoglio è clandestino, il termine per chiedere la reintegrazione decorre dal giorno della scoperta dello spoglio.

La reintegrazione deve ordinarsi dal giudice sulla semplice notorietà del fatto, senza dilazione” (Cod. Proc. Civ. 703 e seguenti).

350 "Fine specifico dell'azione di reintegrazione è il ripristino dela situazione di fato anteriore all'espoliazione, riportando il possessore spogliato nel godimento della coisa usurpata” (ZUCCALÀ, Michele. La difesa del possesso, p. 133).

${ }^{351}$ GUASP, Jaime; ARAGONESES, Pedro. Derecho procesal civil. Procesos declarativos especiales, t. II, p. 101.

352 “La pretensión por privación (§ 861), corresponde a todo aquel a quien la posesión haya sido arrebatada mediante acto de autoridad propia prohibida, sea posesión exclusiva o coposesión; posesión del todo o parte de una cosa; posesión de cosa mueble o inmueble, siendo indiferente si el despojo es o no culpable. [...] La pretensión por inquietación (§ 862) corresponde al poseedor contra el inquietador [...]” (WOLFF, Martín. Tratado de derecho civil. t. III, 1.‥ Derecho de cosas, p. 113).

${ }^{353}$ FABRÍCIO, Adroaldo Furtado. Comentários ao Código de Processo Civil, v. 8, t. III, p. 482. 
tratamento aos dois interditos (arts. 920 a 931), e por isso se aplicam à ação de manutenção de posse as considerações feitas no item anterior. O que as diferencia fundamentalmente é a "causa violadora dos direitos do possuidor", 354 isto é, a causa de pedir e, consequentemente, o pedido, visto que, enquanto na ação de reintegração de posse buscase extirpar o esbulho praticado por terceiro com o objetivo de reconduzir o autor na posse da coisa, na ação de manutenção o objetivo é de assegurar a situação do possuidor e a cessação dos atos que perturbam a sua posse.

Na turbação, o possuidor é impedido de exercer a posse em sua plenitude, não chegando, porém, a ser despojado desse poder ${ }^{355}$ - o que configuraria o esbulho -, devendo a proteção processual ser reclamada por meio da ação de manutenção (arts. 926, CPC, e 1.210, CC) para assegurar a posse ao autor, afastando os atos de terceiros que o atrapalham. Segundo Joel Dias Figueira Jr., tais atos não estão limitados à simples moléstia ao exercício da posse, “mas também à diminuição do uso, gozo, eficácia ou disposição do bem, da tranquilidade, e, em geral, são todos aqueles capazes de interferir negativamente na consecução dos fins sociais e econômicos do bem manutenido”. ${ }^{356}$ Ao buscar o significado de turbação, Tito Fulgêncio a define como todo ato que "escureça, anoiteça, confunda, equivoque e inquiete a posse”. ${ }^{357}$

Sendo assim, a diferença entre a turbação e o esbulho consiste na permanência ou não do agredido na posse da coisa, visto que a turbação se transforma em esbulho no exato momento em que a vítima é alijada da posse da coisa, ou quando toma conhecimento do ato espoliativo. Em outras palavras, “o que diferencia o esbulho da turbação é a circunstância do possuidor”, ${ }^{358}$ pois no esbulho ele perde a posse, ao passo que na turbação

\footnotetext{
${ }^{354}$ AZEVEDO, Renan Falcão de. Posse. Efeitos e proteção, p. 145.

355 “Turbação há quando se lesa a posse sem se chegar ao esbulho” (PONTES DE MIRANDA, Francisco Cavalcanti. Tratado de direito privado, t. X, p. 286). "Quem está na posse, sem que a houvesse tirado de quem a vem turbar, tem o direito de ser mantido" (PONTES DE MIRANDA, Francisco Cavalcanti. Comentários ao Código de Processo Civil, t. XIII. p. 275).

${ }^{356}$ FIGUEIRA JR., Joel Dias. Liminares nas ações possessórias, p. 74.

${ }^{357}$ FULGÊNCIO, Tito. Da posse e das ações possessórias, p. 85.

${ }^{358}$ CIMARDI, Cláudia Aparecida. Proteção processual da posse, p. 156.
} 
ele, apesar da ofensa que impede o pleno exercício da posse, continua a exercer o poder de fato sobre a coisa. ${ }^{359}$

Exemplo de situação que já atormentou a doutrina e induziu em erro a jurisprudência no passado é a da perda da posse sobre parte do imóvel. Renan Falcão de Azevedo questionou, em sua obra, se tal ocorrência configuraria turbação, por não privar o possuidor totalmente de seu direito, ou esbulho. A questão foi apresentada nos seguintes termos:

Determinado cidadão é possuidor de uma área de 1.000 metros quadrados de terras. Certo dia, alguém invade esta área, ocupando um setor de 200 metros quadrados. Há aqui esbulho ou turbação? ${ }^{360}$

Atualmente não há dúvida quanto à qualificação deste fato como esbulho, visto que, em relação à área tomada, o possuidor foi privado de sua posse na integralidade, e não apenas sofreu privação parcial de seu poder; a parcialidade, nesta situação, é da área esbulhada, e não do exercício da posse.

Com esse mesmo entendimento, Pontes de Miranda criticou o entendimento de Theodor Kipp, e fez uma advertência quanto à confusão entre privação parcial da posse com turbação. ${ }^{361}$ Não parece haver divergência, no entanto, entre esse entendimento de Pontes de Miranda e o posicionamento do referido autor alemão que, em coautoria com os doutrinadores Martin Wolff e Ludwig Enneccerus, afirmou que não se trata de mera turbação se o autor constitui para si mesmo uma posse. ${ }^{362}$

\footnotetext{
${ }^{359}$ A turbação "consiste na moléstia à posse, sem, todavia, a excluir, o que quer dizer que esta, embora turbada, continua a existir. O esbulho, ao contrário, a exclui integralmente, de tal modo que o possuidor deixa de o ser. Em ambos os casos, a situação fática torna-se patológica, porque priva a posse do caráter de normalidade, para convertê-la em algo desconforme com a ordem social e com a ordem jurídica. Instalado o vírus da turbação ou do esbulho, torna-se cabível, e até necessário, extirpá-lo, em homenagem à conveniência da restauração da normalidade” (BESSONE, Darcy. Da posse, p. 175).

${ }^{360}$ AZEVEDO, Renan Falcão de. Posse. Efeitos e proteção, p. 145.

361 "Entendia Th. Kipp que pode haver só turbação apesar de ter o ofensor adquirido posse (parcial), - o que é, evidentemente, confundir turbação com privação parcial da posse do outro" (PONTES DE MIRANDA, Francisco Cavalcanti. Tratado de direito privado, t. X, p. 288).

${ }^{362}$ WOLFF, Martin; ENNECCERUS, Ludwig; KIPP, Theodor. Tratado de derecho civil. t. III, $1^{\circ}$. Derecho de cosas, p. 104.
} 
Sobre essa questão também se debruçaram os doutrinadores italianos, e nas suas principais obras o debate aparece intitulado de “spoglio parziale e moléstia”. Ettore Protettí faz referência a um julgado da Suprema Corte italiana que solucionou o referido debate, e conclui, conforme o desfecho do julgamento, que, de fato, na hipótese de esbulho parcial, a parte da coisa da qual o possuidor vem a ser privado marca o limite entre as ações de manutenção e de reintegração, mas, naquela parte, a posse é afastada no total. ${ }^{363}$

É interessante notar que a situação narrada pode decorrer do fenômeno que Pontes de Miranda denominou de "confusão de limites”, 364 ou seja, quando há divergência em relação aos limites de dois ou mais prédios vizinhos. Qualquer um dos proprietários, diante dessa divergência, poderá ajuizar a ação de demarcação (arts. 950 e seguintes do CPC) e, na hipótese de um dos confinantes invadir a área litigiosa, será possível ao demandante cumular pedido de “restituição do terreno invadido” (art. 951, CPC), razão que torna possível ver nesse remédio um conteúdo possessório, não, porém, a ponto de caracterizá-lo como ação possessória pura, dado que o seu fundamento haverá de ser o domínio. ${ }^{365}$ Todavia, se um confinante ocupar indevidamente parte do imóvel do outro, sem que haja dúvidas quanto às linhas de separação das áreas, caberá ao proprietário prejudicado a ação reivindicatória (art. 1.228, CC) ou, sendo também possuidor, as ações possessórias para afastar os atos de turbação ou de esbulho dos confinantes. ${ }^{366}$

363 “[...] infatti, nell'ipotesi di spoglio parziale, la parte di cosa dela quale il possessore viene privato segna i limiti entro i quali si è mantenuta l'azione materiale dello spogliatore, ma il possesso è tolto; e, per quella parte, è tolto del tutto" (PROTETTÍ, Ettore. Le azioni possessorie, p. 496).

364 “Confusão de limites - O fato de se acharem confusos os limites de dois ou mais prédios não obsta a que o possuidor de um deles proponha ação possessória contra o outro possuidor, alguns, ou todos os outros possuidores” (PONTES DE MIRANDA, Francisco Cavalcanti. Comentários ao Código de Processo Civil, t. XIII, p. 274).

${ }^{365}$ A questão é controvertida. João Batista Monteiro entende que, embora não seja ação possessória, a demarcação pode dar origem a questões possessórias, quando, pela demarcação, ocorrer esbulho, e sustenta que, "nesse caso, a solução da pendência possessória depende da ação própria, que não se confunde com a demarcação ou de divisão" (Ação de reintegração de posse, p. 60). Já Antonio Carlos Marcato manifesta o entendimento de que é possível a formulação de "pedido de reintegração na posse, ou reivindicatório de domínio" (Procedimentos especiais, p. 179). Pontes de Miranda prevê, ainda, a possibilidade de ajuizamento de ação possessória na pendência de ação demarcatória (Comentários ao Código de Processo Civil, t. XIII, p. 274), o que evidentemente só seria necessário se não formulado o pedido de restituição na inicial daquela demanda.

366 “Demarcatória - Ação cabível somente quando há confusão de limites na linha divisória - Ausência, na hipótese, de qualquer imprecisão ou incerteza quanto à verdadeira linha divisória - Imóvel dos autores que está devidamente individualizado - Pretensão demarcatória incabível - Localização correta da linha divisória entre os imóveis que é do conhecimento das partes - Autores que, em verdade, pretendem a retomada de área supostamente invadida pelo réu - Falta de interesse-adequação verificada - Eventual 
Pode a turbação ocorrer por diversos meios, seja por atos positivos, seja por atos negativos, sendo que aqueles representam conduta ostensiva do ofensor, com a prática de atos que importam em uso indevido da coisa alheia, enquanto os atos negativos simplesmente impedem que o possuidor exerça livremente a sua posse. Sobre esta questão J. M. de Carvalho Santos assevera que “a turbação pode consistir em atos positivos, como se o turbador, sem expulsar o possuidor, cultiva o terreno, corta árvores, levanta edifícios; ou em atos negativos, como se ele impede o possuidor de praticar atos”. ${ }^{367}$

Também representa turbação o ato que possibilita a ocorrência de consequências prejudiciais à posse, como a ruptura de cercas que dividem dois imóveis rurais e que, como consequência, implica a invasão da um imóvel por animais da outra. ${ }^{368}$ Destaque-se, ainda, que a turbação pode se configurar como um ato jurídico que importe em questionamento judicial ou extrajudicial da posse, como um ato administrativo que revogue arbitrariamente uma concessão, ou mesmo uma decisão judicial que possa acarretar da perda da posse. ${ }^{369}$

Tito Fulgêncio afirma que é ínsito ao esbulho um prejuízo sofrido, que importa na diminuição patrimonial, ${ }^{370}$ mas tal elemento não é condição para a configuração do esbulho; não se exige, para reconhecimento do esbulho, que o possuidor sofra efetivo prejuízo. Imagine-se o exemplo do possuidor que permite ao vizinho passar por seu imóvel rural para encurtar o caminho até a estrada mais própria e, posteriormente, desautoriza-o, sem qualquer motivo ou justificativa. Simplesmente pode não lhe ser mais conveniente ceder a passagem ao vizinho, e, caso este insista em utilizar a área do possuidor,

satisfação dos autores que somente poderá vir a ocorrer por via processual própria” (TJSP, Apelação Cível 994.05.118688-3, 1. ${ }^{a}$ Câmara de Direito Privado, Rel. Luiz Antônio de Godoy, j. 02.02.2010).

${ }^{367}$ CARVALHO SANTOS, J. M. de. Código Civil brasileiro interpretado, v. 7, p. 107.

368 "Na turbação também entram aqueles casos em que o ato turbativo, positivo ou negativo, fez desencadear alguma força natural (= extra-humana), como inundação, incêndio, ação de animais ou de loucos (e.g., abrir a jaula de animais ferozes para molestar na posse, pôr de guarda o louco, armado ou não). A consequência pode levar até o esbulho" (PONTES DE MIRANDA, Francisco Cavalcanti. Tratado de direito privado, t. X, p. 288).

369 “A turbação pode consistir num ato jurídico que importe negação, restrição ou contestação judicial ou extrajudicial do exercício da atividade de possuidor" (ESPÍNOLA, Eduardo. Posse - Propriedade. Compropriedade ou condomínio. Direitos autorais, p. 97-98).

370 “O legislador pressupõe um prejuízo sofrido, uma diminuição de patrimônio contra a qual pressupõe o possuidor, reintegrando-o na plenitude dos seus misteres, e por consequência o ato turbativo não pode deixar de ser um ato material, capaz, ele só de produzir efeito dessa natureza” (FULGÊNCIO, Tito. Da posse e das ações possessórias, p. 86). 
contrariando a sua vontade, estará de per si configurado o esbulho, sendo dispensável a existência de uma consequência danosa desse ato. ${ }^{371}$ Compartilha do mesmo entendimento o alemão Martin Wolff, ao sustentar que a turbação não supõe dano patrimonial algum. ${ }^{372}$

É igualmente dispensável, para a configuração da turbação, a presença do animus turbandi, isto é, a verificação da intenção do agente ofensor da posse - diversamente do que ocorre em relação ao esbulho no caso de aquisição da coisa terceiro, situação em que a análise da intenção do adquirente será de fundamental importância em razão da norma do artigo 1.212 do Código Civil.

Pouco importa, pois, se o ofensor agiu com a intenção de turbar a posse, bastando que $\mathrm{o}$ ato objetivamente embarace a posse alheia para que reste configurada a turbação, sendo dispensável a investigação do animus do ofensor. Como bem ressaltou Cláudia Cimardi, “a turbação se configurará pela simples prática de atos que atrapalhem a posse de outrem, independentemente de perquirição da real intenção do sujeito”. 373

Já a doutrina italiana atribui maior peso ao animus turbandi, tratando-o como requisito psíquico que caracteriza a ação ilícita do turbador, mas Luigi Paolo Comoglio ${ }^{374}$ esclarece que a jurisprudência mais recente tende a excluir esse requisito para configuração da turbação, que é estranho ao texto legal. ${ }^{375}$

371 "O que nos parece certo, pois, é que a turbação resulta do ato em si, independentemente de qualquer intenção. Esta só deve ser tomada em consideração em caso de dúvida sobre o caráter dos fatos que constituem a turbação. Pouco importa, por outro lado, que haja ou não dano para o possuidor. É que a turbação pode existir sem dano. E se alguns escritores falam em dano é preciso ter em vista que a palavra aí está empregada como o próprio fato que altera a posse” (CARVALHO SANTOS, J. M. de. Código Civil brasileiro interpretado, v. 7, p. 107).

372 "La inquietación no supone daño patrimonial alguno" (WOLFF, Martin. Tratado de derecho civil. t. III, $1^{\circ}$. Derecho de cosas, p. 104).

${ }^{373}$ CIMARDI, Cláudia Aparecida. Proteção processual da posse, p. 156.

374 “- il requisito psichico che caratterizza le azioni illecite di spoglio o di trubativa è, dunque, solitamente inteso como conscienza e colontà di compiere atti di modificazione, di alterazione o di turbativa del possesso altrui, sì da essere perlopiù dato per presunto ed insito (in re ipsa) nella materialità di quegli atti, compiuti contro volontà espressa o tacita del possessore; - nell'opinione giurisprudenziale più recente, tuttavia, si tende ad escludere la configurabilità di quel tradizionale requisito, testealmente estraneo alle fattispecie delineate dagli artt. 1168 e 1170 c.c. [...]” (COMOGLIO, Luigi Paolo; FERRI, Corrado; TARUFFO, Michele. Lezioni sul processo civile. II. Procedimenti speciali, cautelari ed esecutivi. p. 77).

375 “Art. 1170. Azione di manutenzione

Chi è stato molestato nel possesso di un immobile, di un diritto reale sopra un immobile o di un'universalità di mobili (816) può, entro l'anno dalla turbativa, chiedere la manutenzione del possesso medesimo (Cod. Proc. Civ. 703 e seguenti).” 
Portanto, para que seja cabível a ação de manutenção de posse, é necessário apenas que o autor tenha a posse e que esta esteja sendo molestada com atos que, embora não o prive totalmente do seu poder sobre a coisa, impede-o de exercê-lo em sua plenitude. Há de ser atual e real, no entanto, a turbação, com a materialização de atos que permitam identificá-la como fato existente, e não apenas como simples receio de ofensa. ${ }^{376}$

É certo que o princípio da fungibilidade, positivado pelo legislador processual para o procedimento especial das ações possessórias - a ser tratado adiante em item específico -, tornaria tal discussão estéril, porquanto o juiz estaria autorizado a conceder a tutela adequada, ainda que não tenha sido ela pleiteada na inicial. Não obstante, mostra-se relevante identificar de antemão e com precisão os atos que representam ofensa à posse, não por preciosismo, mas para que o erro de qualificação dos fatos não se transforme em regra na prática forense. O princípio da fungibilidade não deve ser encarado como remédio para o desleixo e a torpeza; não é esse, como será visto (item 4.7), o objetivo desse princípio positivado no Código de Processo Civil.

Conclui-se, pelo exposto, que a ação de manutenção visa ao afastamento da turbação - que, aliada à posse do autor, integra a causae petendi - por meio de um provimento que impõe obrigação de não molestar a posse daquele que vem a juízo reclamar a tutela jurisdicional possessória, ou de fazer cessarem os atos que importem em perturbação. ${ }^{377}$ Logo, conforme se depreende da lição dos autores espanhóis Jaime Guasp e Pedro Aragoneses - perfeitamente aplicáveis ao sistema brasileiro da ação de manutenção de posse -, por meio da sentença de procedência proferida na ação de manutenção de posse admite-se a pretensão do possuidor em razão da perturbação e se determina a sua manutenção na posse, ordenando ao perturbador que se abstenha de cometer os atos repudiados pelo possuidor. ${ }^{378}$

\footnotetext{
376 "Para o exercício da ação de manutenção é essencial ainda a turbação atual ou real, com possibilidade e perigo de repetição futura, não bastando simples manifestação ou ameaças verbais, certo como é que o remédio possessório, em si, serve para tutelar um estado de fato e não a defesa de uma turbação hipotética” (CARVALHO SANTOS, J. M. de. Código Civil brasileiro interpretado, v. 7, p. 106-107).

377 "O objeto imediato da demanda é manter o possuidor no livre, amplo e perfeito exercício de sua posse" (FIGUEIRA JR., Joel Dias. Liminares nas ações possessórias, p. 74).

378 "Por ello en la sentencia que declara haber lugar a la pretensión por haber sido perturbado el demandante en la posesión o tener fundados motivos para creer que lo será, se mandará mantenerle en la posesión y requerir al perturbador para, que en lo sucesivo, se abstenga de cometer tales actos u otros que
} 
A pretensão do autor da ação de manutenção é, por corolário, manter a sua situação de possuidor, antes que os atos de perturbação avancem para a total privação da posse, com a configuração do esbulho, ou seja, pretende-se "garantir a permanência do mesmo estado de fato, que não chegou a ser desfeito, mas sim e somente perturbado”. ${ }^{379}$

\subsection{Interdito proibitório}

Desde o direito romano, a proteção possessória tem sido estendida da turbação efetiva ou do esbulho até a ameaça de turbação ou de esbulho, conforme ensina Tito Fulgêncio. ${ }^{380}$ Também denominado na doutrina de preceito cominatório, ação de notificação e embargos à primeira, o interdito proibitório admitido em nosso ordenamento é fruto de previsão constante das Ordenações Afonsinas e Manuelinas (Livro III, Título 62, §§ 5-7 e Título 80, §§ 6-9, respectivamente), por meio da qual se assegurava a situação daquele que temesse a conduta de outrem que pretendesse arbitrariamente ocupar e tomar suas coisas.

Dispõe o artigo 932 do Código de Processo Civil que “o possuidor direto ou indireto, que tenha justo receio de ser molestado na posse, poderá impetrar ao juiz que o segure da turbação ou esbulho iminente, mediante mandado proibitório, em que se comine ao réu determinada pena pecuniária, caso transgrida o preceito”. A mesma norma foi inserida no artigo 501 do Código Civil de 1916 e mantida na parte final do artigo 1.210 do Código atual. ${ }^{381}$

Trata-se de medida preventiva cujo objetivo é assegurar o possuidor contra a violência iminente à sua posse, mediante preceito cominatório e com a cominação de pena ao transgressor. ${ }^{382}$ Da mesma forma que na ação de manutenção, no interdito se busca manter a posse que, apesar da ameaça, ainda não foi perdida. A diferença principal entre

\footnotetext{
manifiesten el mismo propósito, bajo el apercibimiento que corresponda con arreglo a derecho” (GUASP, Jaime; ARAGONESES, Pedro. Derecho procesal civil. Procesos declarativos especiales, t. II, p. 104).

${ }^{379}$ FABRÍCIO, Adroaldo Furtado. Comentários ao Código de Processo Civil, v. 8, t. III, p. 482.

${ }^{380}$ FULGÊNCIO, Tito. Da posse e das ações possessórias, p. 120.

381 “Art. 1.210. O possuidor tem direito a ser mantido na posse em caso de turbação, restituído no de esbulho, e segurado de violência iminente, se tiver justo receio de ser molestado.”

${ }^{382}$ FULGÊNCIO, Tito. Da posse e das ações possessórias, p.121.
} 
uma e outra é que, na turbação e no esbulho, o atentado à posse já foi consumado, ao passo que, no interdito, o atentado está apenas no campo da ameaça, não tendo havido qualquer dos atos que efetivamente restringem e privam o exercício da posse.

Portanto, o caráter preventivo do interdito proibitório é o elemento que o distingue dos demais interditos, visto que não se busca, por meio dessa medida, fazer cessar os efeitos de uma agressão já consumada à posse, mas sim afastar a ameaça para resguardar o possuidor, impedindo que essa agressão se materialize. Com isso, no interdito proibitório o provimento jurisdicional consiste na imposição de “um veto (preceito de não fazer, ou seja, de não turbar ou não esbulhar a posse do autor) e uma cominação de pena pecuniária, caso transgredida a ordem judicial (CPC, art. 932)”. 383

Apesar do caráter preventivo e conservativo, o provimento do interdito proibitório não visa apenas resguardar um direito, e sim repelir a ameaça que, por si só, já importa em violação ao direito do possuidor. Por isso, não tem esse provimento natureza cautelar, porém satisfativa. $^{384}$

Não se reputa inteiramente correta a afirmação de que o emprego do interdito proibitório “está ligado às situações em que se pretende evitar a violação possessória”, 385 porquanto a ameaça já representa violação ao direito de posse. É certo que o interdito proibitório tem o objetivo de impedir a consumação de um ato de turbação ou esbulho, mas a ameaça em si mesma já representa uma violação ao direito do possuidor, e por isso é afastada por meio dessa ação possessória típica.

Nesse mesmo sentido, Adroaldo Furtado Fabrício registra que a inclusão do interdito proibitório entre as ações possessórias típicas, em vez de deixá-lo no campo do processo cautelar, em que a função preventiva é a regra, demonstra que a ameaça de

\footnotetext{
383 MARCATO, Antônio Carlos. Procedimentos especiais, p.153.

${ }^{384}$ DESTEFENNI, Marcos. Curso de processo civil, v. 3, p. 398.

${ }^{385}$ MARINONI, Luiz Guilherme; ARENHART, Sérgio Cruz. Procedimentos especiais, p. 111.
} 
violência ou molestação já configura, por si só, uma forma de violação à posse - “a menos grave delas, por certo, mas nem por isso incapaz de efeitos danosos”. ${ }^{386}$

Embora o legislador não tenha feito menção expressa à “ameaça” nos artigos 1.210 do Código Civil e 932 do Código de Processo Civil, extrai-se tal elemento como requisito para provimento do interdito proibitório da expressão “justo receio de ser molestado na posse” e da "violência iminente”.

Os requisitos do interdito proibitório, segundo Tito Fulgêncio ${ }^{387}$ e J.M. de Carvalho Santos, ${ }^{388}$ são dois: (a) que haja posse do autor - requisito exigido em todos os interditos, e que dispensa novos comentários pelo que já foi exposto anteriormente - e o (b) justo receio de moléstia na posse por parte do réu, vale dizer, de violência iminente, que é o elemento que distingue o interdito proibitório das demais ações possessórias típicas. ${ }^{389}$ São estes, portanto, os elementos que compõem a causa petendi do interdito proibitório.

Não basta o mero receio infundado, entretanto, para que seja acolhido o pedido de proteção por meio do preceito cominatório. Há de ser, sim, o receio fundado, e configurado por elementos objetivos que possam transmitir ao juiz a crença sobre a existência de uma ameaça concreta a ser banida, e que não se trata de exagero decorrente de “deformação psíquica”. 390

O receio representa o reconhecimento de fatos concretos que façam suspeitar que o réu molestará a posse do autor, devendo tais fatos ser comprovados pelo demandante que vem a juízo pedir a tutela jurisdicional da posse. Portanto, a ameaça, geradora do justo

\footnotetext{
${ }^{386}$ FABRÍCIO, Adroaldo Furtado. Comentários ao Código de Processo Civil, v. 8, t. III, p. 509.

${ }^{387}$ FULGÊNCIO, Tito. Da posse e das ações possessórias, p. 121.

${ }^{388}$ CAVALHO SANTOS, J. M. de. Código Civil brasileiro interpretado, v. 7, p. 133.

389 "Possessória - Interdito proibitório - Liminar - Autores da ação que demonstraram a posse e o justo receio de que venha ocorrer esbulho ou turbação iminente - Inteligência do art. 932 do CPC - Decisão mantida - Recurso não provido. Assim, para a concessão do mandado proibitório, deve-se comprovar, além da posse, o justo receio de que possa ocorrer esbulho ou turbação iminente” (TJSP, Agravo de Instrumento 00300066-80.2011.8.26.0000, 38. ${ }^{a}$ Câmara de Direito Privado, Rel. Des. Maia da Rocha, DJ 25.05.2012).

${ }^{390}$ FABRÍCIO, Adroaldo Furtado. Comentários ao Código de Processo Civil, v. 8, t. III, p. 510.
} 
receio, configurar-se-á com atos reais e concretos capazes de pôr em risco o estado de fato do possuidor.

Pode a ameaça ser ostensiva, oral ou escrita, como pode também decorrer de atos do ofensor que permitam ao possuidor acreditar que sofrerá turbação ou esbulho. ${ }^{391}$ É o que ocorre, por exemplo, quando terceiros armam acampamento ao lado de uma propriedade rural e demonstram, por comportamento suspeito e atos concretos, que pretendem invadi-la.

J. M. de Carvalho Santos afirma que "não basta a violência provável, porque o Código, exigindo que ela seja iminente, exige mais alguma coisa, a dizer, que a violência seja quase certa". ${ }^{392}$ No entanto, seria de extremo rigor exigir a "quase certeza" da concretização futura da violência, e inclusive ilógica, já que é da natureza do evento futuro a incerteza. Esse rigor tornaria inviável a proteção contra a ameaça, visto que, embora se exija a apresentação de fatos concretos que permitam ao juiz vislumbrar a probabilidade da violência iminente, seria impossível a comprovação in limine da certeza da concretização da violência anunciada pela ameaça, pois esta, na maioria das vezes, se faz de forma velada, sorrateira, sem deixar rastros. Por tais razões, no interdito proibitório “a prova é feita sem forma solene, com os elementos que as circunstâncias permitam”. 393

Sustenta J. M. de Carvalho Santos, ainda, que uma simples promessa de violência, sem a ocorrência de fatos positivos e preparatórios da ação, ou a ameaça verbal ou escrita, que ainda não tenha se transformado em fatos concretos, não poderia ser considerada como violência iminente. $^{394}$ A jurisprudência, embora vacilante, tende a seguir esse entendimento, não considerando, para fins de proteção por meio do interdito proibitório, a ameaça verbal sem qualquer ato preparatório, ${ }^{395}$ posicionamento que persiste, a nosso

\footnotetext{
391 "Resultará de ameaça (verbal ou escrita) ou terá como causa o comportamento do sujeito que exprima a sua vontade inequívoca em traduzir os seus gestos em atos de moléstia (esbulho e turbação)” (FIGUEIRA JR., Joel Dias. Liminares nas ações possessórias, p. 75).

392 CARVALHO SANTOS, J. M. de. Código Civil brasileiro interpretado, v. 7, p. 134.

393 PONTES DE MIRANDA, Francisco Cavalcanti. Comentários ao Código de Processo Civil, t. XIII, p. 318.

${ }^{394}$ CARVALHO SANTOS, J. M. de. Código Civil brasileiro interpretado, v. 7, p. 134.

395 “Interdito proibitório. Improcedência Mera ameaça verbal, desacompanhada de qualquer ato preparatório. Descabimento da proteção possessória. Cerceamento de defesa não caracterizado, diante da
} 
sentir, por irracionalidade, porque a prática dos atos anunciados pela ameaça já deve ser interpretada, no mais das vezes, como turbação ou esbulho, visto que já importam em agressão efetiva e física à posse, extrapolando o campo da cogitação.

Situação diversa, porém, e que se encontra com maior frequência na jurisprudência, é a da ameaça verbal não comprovada, que apenas por isso acarreta a acertadamente a improcedência da ação possessória, ou seja, o que inviabiliza a procedência da ação não é a insuficiência desse fato (ameaça verbal), mas sim a insuficiência de provas da ocorrência desse fato.

Em qualquer dos casos, entendemos que, quando houver dúvidas sobre a credibilidade da ameaça (verbal ou escrita) comprovada, sobretudo na fase de cognição sumária para fins de apreciação de pedido liminar, deve-se optar por conceder a tutela proibitória, que não causará mal algum ao réu, caso este não tenha agido com seriedade ao propalar a ameaça.

Na mesma linha de raciocínio, deve-se considerar que a ameaça de violência iminente à posse não é apenas aquela que deva inevitavelmente acontecer; não se exige a demonstração da certeza de que se materializarão a turbação ou o esbulho em determinado tempo, tampouco a prática de atos que ultrapassem a mera ameaça verbal ou escrita, bastando, entretanto, a previsibilidade e probabilidade de sua ocorrência no futuro próximo, assim como o temor do possuidor gerado pela ameaça; 396 “iminente está aí por futura”. 397

inadmissibilidade da produção de prova oral. Sentença mantida. Recurso não provido” (TJSP, Apelação 9172934-30.2008.8.26.0000, 17. . Câmara de Direito Privado, Rel. Paulo Pastore Filho, j. 04.07.2012, publ. 12.07.2012).

396 “Apelação. Interdito proibitório. O interdito proibitório tutela a posse, garantindo a permanência do possuidor e a abstenção por parte de terceiros da prática de turbação ou esbulho. Trata-se de um remédio conservativo do poder de fato cujo escopo principal perseguido é a manutenção do possuidor na posse do bem, desde que comprovada a posse atual do autor, a ameaça de turbação ou esbulho iminente e o justo receio de ser concretizada a ameaça, evitando-se a consumação de um fato não querido. $\mathrm{O}$ interdito visa a proteger a posse justa, ameaçada, constituindo-se em proteção preventiva da posse. De natureza premonitória, visa a impedir que se consume a violação. Para propor a ação de interdito proibitório, basta que o autor tenha um receio fundado ou justo de que a violência virá, pouco importando a intenção do réu em praticar ou não a turbação ou o esbulho, evitando dessa forma, a consumação do fato não querido. As provas contidas nos autos, oriundas de documentos e depoimentos de testemunhas, levam a concluir que a razão está com a Apelada no que tange à ameaça praticada pelo Apelante em relação à posse do imóvel objeto da presente ação. Proprietária e efetiva possuidora do imóvel, a Apelada sofreu, sim, ameaças à 
Não é necessária, ainda, a ameaça de ação imediata para que seja concedida a proteção por meio do interdito proibitório, bastando que seja previsível a concretização da agressão em um tempo próximo. Como bem ressaltou Adroaldo Furtado Fabrício, “não é razoável exigir que o autor espere até a undécima hora para socorrer-se do interdito, arriscando-se a frustrar, pela demora, a função preventiva do remédio”. 398

Para corroborar tais assertivas, tanto em relação à mera ameaça quanto no tocante à iminência da violência, imagine-se a seguinte situação: locatário de imóvel residencial deixa de pagar um aluguel e, por isso, é avisado pelo locador que, na semana seguinte, o despejará por força própria, sem que, para tanto, tenha sido ajuizada a competente ação de despejo. Diante disso, o locatário propõe o interdito proibitório comprovando essa ameaça verbal - seja por meio de testemunha em audiência de justificação ou gravação de áudio ou de vídeo apresentada na inicial. Ora, não estariam configurados os requisitos para a concessão da medida protetiva? Deveria o locatário aguardar a chegada do locador no dia do anunciado despejo arbitrário e o início da retirada dos seus pertences do imóvel para, somente depois, ajuizar o preceito cominatório? Tais elementos configuram a situação de ameaça e justo receio capaz de ensejar o acolhimento do interdito proibitório, e aguardar a prática dos atos anunciados na ameaça tornaria imprestável esse interdito, visto que já estaria configurada ao menos a turbação, combatível por meio da ação de manutenção.

Não configura ofensa e ameaça a posse, todavia, o exercício regular de direito, que pode ser representado por meio de notificação judicial ou extrajudicial e, ainda, pelo ajuizamento de ação que tem por fim a retomada da posse da coisa, seja com fundamento no direito de propriedade ou na própria posse anterior alegada pelo terceiro. Nesse sentido, Adroaldo Furtado Fabrício ${ }^{399}$ sustenta que não é ofensa que desafia o interdito proibitório o

posse, perpetradas pelo Apelante. Os testemunhos colhidos no transcorrer da instrução comprovaram as ameaças, efetivadas de forma indireta, mas efetivas para criar temor à Apelada. Era fundado o receio da Apelada em ver a posse de seu imóvel possivelmente molestada, o que lhe autorizava o ingresso da demanda de interdito e a consequente procedência em face do Apelante” (Apelação 000009591.2010.8.26.0418, 38. ${ }^{a}$ Câmara de Direito Privado, Rel. Eduardo Siqueira, j. 01.08.2012, publ. 06.08.2012).

397 PONTES DE MIRANDA, Francisco Cavalcanti. Tratado de direito privado, t. X, p. 458-459.

${ }^{398}$ FABRÍCIO, Adroaldo Furtado. Comentários ao Código de Processo Civil, v. 8, t. III, p. 512.

399 “O que importa é a seriedade da ameaça, sua credibilidade, sua aptidão pata infundir num espírito normal o estado de receio. Esta, por outro lado, pode ter existência real, mas se em si mesma 'justa', no sentido de representar o exercício regular de um direito por parte de quem a faz. A propositura ou a promessa de 
anúncio de ação possessória ou reivindicatória, porquanto, apesar do risco de perda da posse, a moléstia, nesse caso, seria legítima. ${ }^{400}$ Embora ainda se encontre divergência na jurisprudência, ${ }^{401}$ prevalece o entendimento já pacificado na doutrina mencionada. ${ }^{402}$

Presentes os requisitos exigidos para o acolhimento do interdito proibitório, deverá o juiz conceder a liminar e, ao final, proferir sentença, com o objetivo de determinar ao réu que se abstenha de praticar atos contrários e violadores do direito de posse do autor, cominando pena pecuniária que deverá incidir na hipótese de descumprimento por parte do réu.

propor uma ação reivindicatória; o decreto de desapropriação e a notificação ao locatário da intenção do locador de retomar o imóvel locado são certamente atos que, objetivamente considerados, ameaçam a posse, no sentido de que colocam a probabilidade concreta de sua perda. Nem por isso ensejarão o interdito, porque a prometida moléstia à posse seria legítima” (FABRÍCIO, Adroaldo Furtado. Comentários ao Código de Processo Civil, v. 8, t. III, p. 511).

${ }^{400}$ No mesmo sentido: "Não revela propósito de ofensa à posse quem pede à justiça tutela aos seus direitos à posse, ou à posse” (PONTES DE MIRANDA, Francisco Cavalcanti. Tratado de direito privado, t. X, 457).

${ }^{401}$ Ementa: “Apelação cível. Posse. Bens imóveis. Interdito proibitório. Ausência de ameaça e de justo receio". Trecho do voto do Relator: "Quanto ao receio dos autores, de serem molestados em sua posse, tenho como comprovado o fato, em especial diante da referida notificação (a qual já deixa claro que o Condomínio demandado questiona os direitos dos apelados sobre a área), e, sobremaneira, pelo ajuizamento de ação, em que o demandado postula a demolição dos boxes de estacionamento existentes". Trecho do voto divergente do revisor: "Segundo a doutrina e a jurisprudência, predomina em nosso direito o entendimento de que o interdito seja proteção preventiva da posse o que pressupõe esteja esta na iminência de ser molestada. Assim, deve ser requisito essencial do interdito proibitório a prova da prática de atos por parte do réu que levem à fundada previsão de perigo ou de violência iminentes. Na situação vertente, pelo que se contém no próprio petitório dos requerentes, estaria presente esta ameaça, para autorizar a expedição de um decreto favorável a sua pretensão? Tenho que não. Os autores não têm a proteção que buscaram. Primeiro, porque a deliberação tomada em assembleia, de buscar informações sobre os proprietários dos imóveis, que deu origem à notificação extrajudicial de fl. 14, colima tão somente a entrega na administração, de documento de propriedade da área localizada na parte dos fundos do condomínio, dita como box, que vem sendo utilizada pelo notificado. Não agride a posse dos requerentes e de nenhum dos outros condôminos. Por segundo, porque o interdito proibitório não se presta para proteger posse alegadamente ameaçada por provável ajuizamento de ação futura pelo réu"

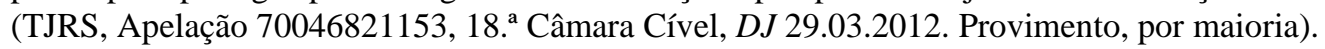

402 "Interdito proibitório. Nulidade da sentença inocorrente. A simples notificação, como medida preparatória de eventual demanda judicial, no exercício de um regular direito, não caracteriza justificável ameaça de turbação ou esbulho, que coloque a posse sob risco de violência iminente. Pretensão possessória improcedente, com a confirmação do decisum. Recurso improvido” (TARS, Apelação Cível 196101174, $8^{a}$ Câmara Cível, J. 06.08.1996). "Apelação cível. Ação de interdito proibitório. Posse direta e justo receio de moléstia na posse. Comprovação. Notificação extrajudicial. Irrelevância. Continuação da possuidora na posse (art. 1.196 do Código Civil). Recurso não provido.” (TJPR, Apelação 902291-7, Rel. Stewalt Camargo Filho, j. 25.07.2012, 17. ${ }^{a}$ Câmara Cível). "Não há como impedir-se, via interdito proibitório, utilização das vias judiciais por quem sofrer violação de direito, porquanto não há ação que possa inviabilizar o princípio constitucional do livre acesso ao Poder Judiciário, implicando ofensa a esse princípio pretensão tendente a neutralizá-lo" (TJSP, Apelação 0001329-55.2008.8.26.0038, 30. ${ }^{\text {a Câmara }}$ de Direito Privado, Rel. Orlando Pistoresi, j. 16.03.2011, publ. 21.03.2011). 
Tem-se nesse provimento, portanto, assim como na ação de manutenção de posse, a obrigação de não fazer dirigida ao réu, de modo a impedi-lo de novamente ameaçar a posse do demandante. Diante dessa constatação, Pontes de Miranda afirma que "a proibição constitui simples preponderância da negatividade, da abstenção, em vez da positividade do ato que o Estado ordena parta de umas das pessoas”. 403

A cominação de pena pecuniária, como bem destacou Adroaldo Furtado Fabrício, é da essência do interdito proibitório, pelo que estabelece o autor semelhança entre essa ação possessória e as ações cominatórias. ${ }^{404}$ A fixação de seu valor não encontra critério na lei, e por isso deve decorrer do bom senso e da proporcionalidade para que sirva de desestímulo às novas ofensas sem, entretanto, superar o valor do dano que se pretende evitar com a medida protetiva ou o benefício econômico do qual se beneficiaria o infrator.

\subsection{Especialidade procedimental: razões para a manutenção do procedimento especial para as “ações possessórias”}

O procedimento representa o modo pelo qual se desenvolvem as atividades tendentes a atingir o provimento jurisdicional, e por isso se sustenta que o procedimento prepara o provimento final. Segundo Cândido Rangel Dinamarco, “procedimento é o conjunto ordenado dos atos mediante os quais, no processo, o juiz exerce a jurisdição e as partes a defesa de seus interesses”; 405 “é o meio extrínseco pelo qual o processo se instaura, se desenvolve e termina”, 406

Preocupa-se a doutrina, com razão, em diferenciar os termos "processo" e “procedimento", que muitas vezes são utilizados de forma indistinta. O processo é o instrumento estatal por meio do qual se reclama a prestação jurisdicional com o objetivo de solucionar litígios pela aplicação do direito material, enquanto o procedimento define a forma de realização dos atos que compõem o processo. A correta compreensão dessas definições faz-se necessária não apenas por preciosismo terminológico, mas é

\footnotetext{
403 PONTES DE MIRANDA, Francisco Cavalcanti. Tratado de direito privado, t. X, p. 455.

${ }^{404}$ FABRÍCIO, Adroaldo Furtado. Comentários ao Código de Processo Civil, v. 8, t. III, p. 512.

405 DINAMARCO, Cândido Rangel. Instituições de direito processual civil, v. 2, p. 454.

${ }^{406}$ MARCATO, Antônio Carlos. Procedimentos especiais, p. 54.
} 
indispensável para que se defina a competência legislativa, visto que é privativa da União a competência para legislar sobre processo (art. 22, inciso I, da Constituição Federal). ${ }^{407}$

Os procedimentos costumam ser divididos em duas categorias: o procedimento comum, que engloba o ordinário e o sumário, e os procedimentos especiais. Tanto os procedimentos especiais quanto o sumário são aplicados às relações de direito material previstas pelo legislador processual, enquanto o ordinário, pelo critério residual, cabe nas demais hipóteses não regulamentadas especificamente.

Nesse sentido, o procedimento deve, sempre que possível, ser disciplinado de acordo com o critério da funcionalidade, de modo que os atos que o compõem sejam adaptados para tutelar com eficiência o direito material.

A criação de diversos procedimentos pelo Estado e a organização dos atos que os compõem têm como objetivo fazer do processo um instrumento eficaz para solução de conflitos gerados pela ameaça e violação de direitos de qualquer natureza, ${ }^{408}$ o que demonstra que a variação do procedimento leva em conta as situações substanciais, reduzindo, assim, a separação entre direito e processo. ${ }^{409}$

Com isso, mostra-se correta a afirmação de que a especialização procedimental atende à exigência de fazer do processo um instrumento a serviço do direito material, tornando-o mais efetivo na medida em que estreita a relação entre a estrutura procedimental e a situação posta pela demanda.

407 "Em síntese, tem-se que enquanto o processo é um instrumento de atuação da Jurisdição, para o exercício do direito de ação e de defesa, composto, como regra, de inúmeros atos processuais que o levam do pedido inicial ao final provimento, o procedimento é o modo, a maneira como estes diversos atos processuais se combinam em contraditório (sua ordem, forma, prazo e tempo), algo que é determinado pela lei ou por circunstâncias ligadas às pessoas ou à causa” (GAJARDONI, Fernando da Fonseca. Flexibilização procedimental, p. 38).

408 "Por outro lado, há os procedimentos especiais, previstos para situações nas quais, em virtude das peculiaridades que delineiam a relação de direito substancial, há necessidade de ser alterada a forma de desenvolvimento do processo, objetivando, em certas hipóteses, uma tutela jurisdicional mais célere" (TEIXEIRA, Guilherme Freire Barros. Teoria do princípio da fungibilidade, p. 203).

409 "A relativização do binômio direito-processo constitui inafastável premissa de um sistema processual eficiente, pois a tutela jurisdicional vai atuar exatamente no plano das relações substanciais" (BEDAQUE, José Roberto dos Santos. Direito e processo: influência do direito material sobre o processo p. 23). 
Entretanto, a especialidade procedimental já foi vista por muitos doutrinadores como resquício do período imanentista, ${ }^{410}$ ou até mesmo das legis actiones do direito romano, em que a proteção de um direito somente era possível se houvesse na lei uma “ação”, que na realidade era confundida com o próprio direito substantivo.

É certo que pensamentos dessa natureza ainda nos perseguem, o que se atesta quando se veem, ainda hoje, questionamentos sobre o cabimento da denominada ação de imissão na posse, somente por não ser mais disciplinada pelo Código de Processo Civil. ${ }^{411}$ No entanto, a tutela jurisdicional de um direito não depende da regulamentação de um procedimento especial destinado a protegê-lo. ${ }^{412}$

Outros doutrinadores, atentos à visão instrumentalista do processo, não criticam a manutenção dos procedimentos especiais por entenderem que se trata de resquício da fase imanentista do processo, mas sim por entender que a generalização da tutela antecipada e a positivação das regras dos artigos 461 e 461-A do Código de Processo Civil tornaram o procedimento ordinário um meio universal para a solução de todo e qualquer litígio. ${ }^{413}$

É verdade que, se não houvesse o procedimento especial, a ação de reintegração de posse poderia muito bem ser denominada de “ação de obrigação de entrega de coisa” e estar fundamentada no artigo 461-A do Código de Processo Civil, assim como o objeto da ação de manutenção de posse e do interdito proibitório poderiam ser tutelados por meio de “ação de obrigação de não fazer” com base no artigo 461 do Código de Processo Civil. E,

${ }^{410}$ MARINONI, Luiz Guilherme; ARENHART, Sérgio Cruz. Procedimentos especiais, p. 26-27.

411 “Qualquer que seja a solução legislativa encontrada, quer o legislador lhe reconheça a existência, ou, ao contrário, tente expulsá-la do sistema, a ação de imissão de posse, evidenciando uma inquebrantável vitalidade, continua presente nas controvérsias doutrinárias, insinuando-se quotidianamente no foro, a desmentir os que teimam em desconhecer-lhe utilidade prática” (SILVA, Ovídio A. Baptista da. Ação de imissão de posse, p. 79).

412 “Ninguém vá pensar, também, que se não fossem os dispositivos legais acerca das ações possessórias as violações à posse não poderiam ser lamentadas em juízo” (DINAMARCO, Cândido Rangel. Fundamentos do processo civil moderno, v. 1, p. 483).

413 "Por todo o exposto, os artigos 461 e 461-A, ambos do Código de Processo Civil, possuem caráter fundamentalmente fungível em relação aos procedimentos especiais previstos no Livro IV, também do diploma processual vigente [...] Entretanto, com o advento da tutela específica, dispensa-se a variedade de requisitos, a variabilidade de procedimentos e a discriminação exaustiva dos meios probatórios” (SANTOS FILHO, Ronaldo Fenelon. A inviabilização dos procedimentos especiais do Código de Processo Civil. In: WAMBIER, Luiz Rodrigues (Coord.). As novas fronteiras do direito processual, p. 629). 
partindo dessa premissa - verdadeira -, chega-se à equivocada conclusão de que não é necessário manter os procedimentos especiais para proteção das diferentes situações de direito material.

Na realidade, a “ação” é uma só, e não admite classificações, devendo ser compreendida como o direito de buscar perante o Estado, por meio do processo, a proteção de um direito. ${ }^{414}$ A especialidade do procedimento indica, quando muito, "tipicidade das formas de reclamar a tutela jurisdicional, não tipicidade das ações”. 415

Portanto, é certo que a existência de apenas um procedimento - o ordinário, com toda a sua completude cognitiva e procedimental - seria suficiente para que qualquer direito substantivo fosse protegido por meio da tutela jurisdicional. ${ }^{416}$ Entretanto, mais do que buscar a "suficiência”, aqui compreendida como o mínimo necessário para o funcionamento do processo, é preciso visar a "eficiência”.

O que se pretende defender é que o procedimento ordinário, embora possa tutelar qualquer direito material, não garante efetividade ao processo; as particularidades de algumas situações substanciais devem ser tratadas de forma diferenciada no processo judicial. Antonio Carlos Marcato sustenta que “a criação desses procedimentos especiais vincula-se ao ajuste da forma ao objeto da ação, com o que se estabelece uma perfeita correspondência entre os trâmites do processo e o direito que se pretende fazer reconhecido ou efetivo". ${ }^{417}$ Os direitos transindividuais, por exemplo, exigem regras processuais próprias, e por isso o procedimento dos processos coletivos recebeu adaptações.

\footnotetext{
414 “Ação é uma e só uma, invariável, e que não se confunde com o direito ameaçado ou lesionado e que justifica a ruptura da inércia do Estado-juiz para que, reconhecido, seja satisfeito de maneira substitutiva e coercitiva” (BUENO, Cassio Scarpinella. Curso sistematizado de direito processual civil, v. 2, t. II, p. 31).

${ }^{415}$ DINAMARCO, Cândido Rangel. Fundamentos do processo civil moderno, 3. ed., t. I, p. 484.

416 "Para não parecer que sou apenas um discursador inconsequente ou um iconoclasta, como já me cognominou um colega, vou tentar analisar dois procedimentos especiais para ver em que consiste essa tão importante especialidade. Escolho, por exemplo, os interditos possessórios. Qual sua especialidade procedimental? A previsão de liminar, que outra coisa não é senão antecipação da tutela, instituto que deveria merecer regulamentação de caráter geral para sua aplicabilidade (por juízes responsáveis) em todos os casos em que isso se impusesse" (CALMON DE PASSOS, José Joaquim. Teoria geral dos procedimentos especiais, p. 3).
}

${ }^{417}$ MARCATO, Antônio Carlos. Procedimentos especiais, p. 57. 
O iminente advento de um Novo Código de Processo Civil trouxe a discussão sobre a necessidade ou não de manutenção de alguns procedimentos especiais, e nesse contexto chegou-se a cogitar a extirpação do procedimento das ações possessórias, sob o argumento de que o advento da regra geral da tutela antecipada eliminaria a necessidade de manter a especialidade procedimental que, aos olhos de muitos juristas, teria de especial apenas a possibilidade de concessão de liminar. ${ }^{418}$

Apesar de louvável a intenção de simplificar o Código de Processo Civil, não se pode olvidar que alguns dos procedimentos especiais tornam mais eficiente e segura a prestação jurisdicional em determinadas situações, dado que o conceito correto de procedimento especial revela a necessidade de adaptação do procedimento às especificidades da relação jurídica de direito material, não apenas por meio de normas procedimentais, mas sobretudo de normas processuais. ${ }^{419}$

Ousa-se discordar da afirmação de que o procedimento das ações possessórias tem de especial apenas a possibilidade de concessão de medida liminar no artigo 924 do Código de Processo Civil. ${ }^{420}$ Isso porque o procedimento especial previsto nos artigos 920 e seguintes do Código de Processo Civil tem inúmeras regras que o distanciam do

418 “O que caracteriza as 'ações possessórias' como 'procedimento especial', isto é, como um procedimento que se contrapõe ao comum-ordinário ou ao comum-sumário, é a possibilidade, prevista pelo art. 924, de concessão de 'medida liminar' apta a proteger, antes mesmo da citação do réu, a chamada 'posse nova' ou de 'força nova', isto é, quando iniciado o processo 'dentro de ano e dia da turbação ou do esbulho" (BUENO, Cassio Scarpinella. Curso sistematizado de direito processual civil, v. 2, t. II, p. 69).

419 “[...] é bem sabido que a existência de procedimentos especiais surge justamente em razão da necessidade de adaptar o modelo básico de prestação da tutela jurisdicional (previsto no Código de Processo Civil e consubstanciado no procedimento comum de conhecimento) a particulares exigências do direito material. Essa adequação não se resume, como se poderia pensar, a aspectos meramente procedimentais (ou seja, atinentes à forma, sequencia, encadeamento e sumarização dos atos praticados pelos sujeitos processuais). Há procedimentos especiais que têm regras específicas relativas à legitimação, à competência, à coisa Julgada, estabelecem limitações horizontais à cognição judicial etc. Em todos esses casos, os procedimentos especiais são informados, em verdade, por normas diferenciadas de caráter processual" (SICA, Heitor Vitor Mendonça. Reflexões em torno da teoria geral dos procedimentos especiais. Revista de Processo, v. 208, p. 66).

420 "Ademais, mesmo quando o esbulho ou a turbação for de mais de ano e dia, nada obsta que o magistrado antecipe, a pedido do autor, a tutela jurisdicional pretendida sobre a posse. Para tanto, devem ser demonstrados os pressupostos do art. 273 (vide n. 2 do Capítulo 1 da Parte I do v. 4), sendo insuficiente, nessa hipótese, antecipar a tutela com base em mero juízo isolado de 'evidência'. Embora por fundamentos bastante diferentes, até porque residentes em planos diversos, o material e o processual respectivamente, os efeitos práticos e sensíveis do processo, nessas duas hipóteses, são os mesmos, a despeito de não existir qualquer regra que torne 'especial' o procedimento das ações possessórias" (BUENO, Cassio Scarpinella. Curso sistematizado de direito processual civil, v. 2, t. II, p. 70). 
procedimento comum, tornando a sua manutenção útil e conveniente, como a positivação do princípio da fungibilidade, a pena para o caso de nova ofensa à posse, a vedação de ação sobre reconhecimento de domínio, a exigência de caução quando for comprovada a inidoneidade financeira do autor, a liminar sem exigência da demonstração do risco de dano, a audiência de justificação prévia, a exigência de prévia oitiva do representante para a concessão de liminar contra pessoas de direito público, o caráter dúplice, que autoriza a formulação de pedido pelo réu em contestação, e a previsão de contagem do prazo de contestação a partir da decisão que deferir ou não a liminar, caso tenha sido realizada audiência de justificação.

Não se discorda de que parte dessas regras do procedimento especial das ações possessórias poderia ser extraída da interpretação de outros dispositivos legais vigentes. A norma do artigo 920 do Código de Processo Civil, ${ }^{421}$ por exemplo, que dispõe sobre a fungibilidade entre as ações possessórias, poderia ser extraída, com alguma limitação, do artigo 462 do mesmo diploma. ${ }^{422}$

Diz-se “com alguma limitação” porque o artigo 462 autoriza que o juiz considere fato modificativo posterior ao ajuizamento da ação, ou seja, a norma do artigo 920 poderia até ser substituída por essa na hipótese de modificação da situação de fato após a propositura da ação possessória, como se vê quando a turbação evolui para esbulho após o ajuizamento da ação de manutenção de posse. Entretanto, a norma do artigo 920 tem maior abrangência, pois impõe ao juiz que outorgue proteção possessória ao autor mesmo que de natureza diversa daquela pleiteada, ou seja, mesmo que o autor tenha deduzido erroneamente seu pedido - reintegração de posse na hipótese de turbação -, o juiz está autorizado a conceder a tutela jurisdicional adequada, motivo pelo qual se torna indispensável a expressa previsão legal da norma do artigo 920.

De igual modo, a justificação prévia disposta no artigo 928 do Código de Processo Civil também está prevista em outros dispositivos do Código de Processo Civil (arts. 802,

\footnotetext{
421 “Art. 920. A propositura de uma ação possessória em vez de outra não obstará a que o juiz conheça do pedido e outorgue a proteção legal correspondente àquela, cujos requisitos estejam provados.”

422 “Se, depois da propositura da ação, algum fato constitutivo, modificativo ou extintivo do direito de influir no julgamento da lide, caberá ao juiz tomá-lo em consideração, de ofício ou a requerimento da parte, no momento de proferir a sentença.”
} 
inciso II, 804, e 861 a 866). No entanto, a sua previsão no procedimento especial das ações possessórias permite ao autor reforçar a sua prova com o objetivo de obter a liminar de proteção possessória, visto que "tal audiência não tem como finalidade antecipar a fase instrutória do processo, apenas viabilizar que o autor prove a necessidade de sua imediata proteção possessória, antes e independentemente daquela fase”. ${ }^{423}$ Portanto, seja por resultado da prática forense, seja por imposição legal, é certo que a audiência de justificação ocorre com muito mais frequência no procedimento das ações possessórias do que em qualquer outra medida cautelar prevista no Código de Processo Civil, o que demonstra a necessidade e utilidade da manutenção da regra do seu artigo 928, que torna mais efetiva a prestação jurisdicional para proteção da posse.

Logo, analisando detidamente as regras que tornam especial o procedimento das ações possessórias, tem-se que, muito embora seja possível encontrar no ordenamento normas semelhantes que poderiam, em tese, se bem interpretadas, substituí-las, é certo que a previsão específica do procedimento especial torna muito mais eficiente e efetivo o processo, sendo certo que, em relação à liminar das ações possessórias, não há no Código de Processo Civil outra norma que autorize a concessão de tutela antecipada sem a presença do requisito da urgência - à exceção do $\S 6 .^{\circ}$ do artigo 273 , que trata de pedido incontroverso -, instituto que parte da doutrina denomina de tutela de evidência. ${ }^{424}$

Aliás, anda no tocante à liminar das ações possessórias, é certo que a revogação do artigo 523 do Código Civil de 1916, que estabelecia a diferença entre posse nova e posse velha e não encontra correspondente no Código Civil de 2002, não afasta do ordenamento jurídico tal diferenciação, tampouco a possibilidade de tratamento diverso de uma e de outra, por força do artigo 924 do Código de Processo Civil, ${ }^{425}$ mantendo-se, portanto, o procedimento especial para a hipótese de ofensa à posse com menos de ano e dia. Ao comentar o artigo 924 do Código de Processo Civil, Joel Dias Figueira Junior afirma que "essa regra procedimental não é incompatível com o sistema do CC, mas lhe é complementar, de modo que, mesmo na omissão do novo diploma civil, continua em pleno

\footnotetext{
${ }^{423}$ BUENO, Cassio Scarpinella. Curso sistematizado de direito processual civil, v. 2, t. II, p. 75.

${ }^{424}$ FUX, Luiz. Tutela de segurança e tutela da evidência.

425 “Art. 924. Regem o procedimento de manutenção e de reintegração de posse as normas da seção seguinte, quando intentado dentro de ano e dia da turbação ou do esbulho; passado esse prazo, será ordinário, não perdendo, contudo, o caráter possessório.”
} 
vigor o regime dos interditos possessórios regulados procedimentalmente, agora, somente pelo CPC”, ${ }^{426}$ entendimento partilhado também por Fredie Didier Jr. ${ }^{427}$

Muito embora concorde com tal posicionamento, Cassio Scarpinella Bueno critica a presença desse regramento no Código de Processo Civil, por se tratar de norma “indesmentivelmente material”. ${ }^{428}$ Parece-nos, entretanto, que não se trata de norma de direito material aquela do artigo 924 do Código de Processo Civil, que dispõe sobre a hipótese em que deverá prevalecer o procedimento especial com a concessão de liminar. Nesse ponto, a lei processual apenas regulamentou um procedimento especial para uma determinada situação jurídica de direito material, e tal norma não nos parece ser puramente de direito material, mas somente o aproxima da regra processual. ${ }^{429}$

Sendo assim, pode-se concluir que o procedimento especial para a proteção da posse trata de regras procedimentais e processuais que, se não estivessem previstas na lei, deixariam ao arbítrio do juiz a adaptação do procedimento ordinário às necessidades do caso concreto, o que, embora seja possível, torna mais insegura e imprevisível a prestação da tutela jurisdicional, diminuindo assim a efetividade do processo. Corroborando esse entendimento, o processualista italiano Luigi Paolo Comoglio assevera que a opção legislativa pelo procedimento típico (especial) atende às exigências de segurança, previsibilidade e igualdade entre as partes, garantindo, assim, a imparcialidade do juiz. ${ }^{430}$

\footnotetext{
${ }^{426}$ NERY JUNIOR, Nelson; NERY, Rosa Maria de Andrade. Código Civil comentado, p. 948.

${ }^{427}$ DIDIER JR., Fredie. Regras processuais no Código Civil, p.140.

${ }^{428}$ BUENO, Cassio Scarpinella. Curso sistematizado de direito processual civil, v. 2, t. II, p. 69.

429 "Nos procedimentos especiais de jurisdição contenciosa, utiliza técnica de identificação a partir da natureza do direito substancial em litígio: ações possessórias etc. Embora possa levar a equívocos, pois a ação é direito abstrato, não vinculado à existência de um direito substancial, e, portanto, não sujeita à tipicidade pretendida pelo legislador, não se pode negar que o fenômeno revela a necessária aproximação entre os dois grandes ramos do ordenamento" (BEDAQUE, José Roberto dos Santos. Direito e processo: influência do direito material sobre o processo, p. 52).

430 'L'pizione legislativa non è affato uma novità, nel panorama degli ordinamenti moderni. L'esperienza dei sistemi di civil law, a dir il vero, dimonstra di preferire l'ammissibilità di misure cautelari tipiche, secondo tpologie predeterminate dala legge, aderendo alle esigenze di certeza, di prevedibilità e di pari garanzia per le parti, le quali giustificano il formalismo processuale, a salvaguardia dell'imparzialità del giudice. È, invece, oposta la tendenza dominante nei sistemi di common law, ove si preferisce lasciare al giudice la possibilità di adottare rimedi provvisori dal contenuto atípico e indeterminato, i quali siano capaci di adattarsi allevariabili caratteristiche del caso concreto, attuando com maggiore elasticità l'effetività dela tutela giudiziaria. Ma le soluzioni positive rispecchiano, perlopiù, scelte di carattere compromissorio, armonizzando fra loro la tipicità di base e l'atipicità residuale di determinati rimedi.
} 
Logo, não há dúvidas de que o procedimento das “ações possessórias” é muito mais eficiente do que seria o procedimento ordinário para proteger a posse contra as moléstias que contam com menos de ano e dia. O mesmo se pode dizer em relação à ação de despejo, que segue o procedimento previsto na Lei 8.245/1991, ao mandado de segurança, aos embargos de terceiro etc.

Essa necessidade de adaptação do procedimento para a tutela de determinados direitos decorre do fenômeno que João Mendes de Almeida Junior denominou “índole da ação”, ao explicar que há uma tendência de o processo se operar de certo modo, relacionado com a natureza do direito tutelado. ${ }^{431}$ Assim, a natureza da posse e a sua violação exigem que o Estado disponibilize um meio de tutela eficaz que permita restabelecer a situação de fato, antes existente, de um modo peculiar, diverso daquele utilizado para a tutela de outros direitos que não exigem a “customização" de um procedimento especial.

Por isso, a omissão do legislador no tocante a direitos cuja tutela depende de um procedimento especial é prejudicial à atividade jurisdicional, porquanto não se alcançaria a efetividade do processo se utilizados meios inadequados para prestar a tutela jurisdicional em determinada situação. ${ }^{432}$

Por outro lado, é oportuna e de igual peso a ponderação feita por José Joaquim Calmon de Passos de que a especialidade procedimental deve ser "uma exceção, só justificável em face da absoluta necessidade de se atender a algo tão específico que seria

Così accade, ad esempio, in Germania e in Austria, o anche in Spagna” (COMOGLIO, Luigi Paolo; FERRI, Corrado; TARUFFO, Michele. Lezioni sul processo civile. II. Procedimenti speciali, cautelari ed esecutivi. Il Mulino. Strumenti. p.21).

431 “A índole, dizem os Filósofos, é a tendência do ente para operar de um certo modo; e, neste sentido, a índole se confunde com a natureza do direito acionado, porque a natureza é o princípio da atividade de um ente, ou no seu modo de ser, ou no seu modo de operar. É um axioma: modus operandi, cognoscendi, proedicandi, sequitur modum essendi, isto é, 'o modo de operar, de conhecer, de atribuir, segue o modo de ser’. Esta ligação íntima demonstra que melhor pode determinar a tendência ou disposição dos atos do processo, isto é, a índole ou modo de operar da ação, aquele mesmo Poder que determina o modo de ser do respectivo direito” (ALMEIDA JUNIOR, João Mendes. Direito judiciário brasileiro, p. 236).

432 “Ao disciplinar qualquer procedimento especial, o legislador se depara com dois riscos: o de deixar de alterar o procedimento comum naquilo que seria necessário para uma adequada tutela dos direitos materiais, ou modificá-lo sem benefício algum à atividade jurisdicional. Ambos os deslizes produzem consequências insidiosas” (SICA, Heitor Vitor Mendonça. Reflexões em torno da teoria geral dos procedimentos especiais. Revista de Processo, n. 208, p. 70). 
disfuncional e até lesivo adotar-se na sua inteireza o procedimento ordinário”, 433 pois, evidentemente, seria inviável e desnecessária a criação de um procedimento para cada direito a ser tutelado, devendo ser empregada a especialidade procedimental nas hipóteses realmente necessárias.

\subsection{Natureza jurídica das ações possessórias}

As ações possessórias têm natureza pessoal, embora ainda seja alvo de polêmica o debate sobre a sua natureza jurídica, se são reais ou pessoais. Já se tratou em capítulo anterior sobre a natureza jurídica da posse (item 2.3), com a conclusão de que se trata de direito pessoal. Em relação à natureza jurídica das ações possessórias, portanto, não poderia ser diverso o entendimento: não são ações reais. ${ }^{434}$

Conforme destacou Eduardo J. Couture, a classificação tradicional em ações reais ou pessoais alude diretamente ao direito que é objeto da pretensão processual, dado que nas ações reais o autor pretende a tutela de um direito real, e nas pessoais, a tutela de um direito pessoal. ${ }^{435}$

A doutrina classifica as ações como pessoais ou reais, assim como petitórias e possessórias, quando, na verdade, a classificação é das pretensões, com base no direito substancial. ${ }^{436} \mathrm{O}$ correto é que a classificação fosse das ações fundadas em direito real e em direito pessoal, mas, para facilitar a identificação da via judicial na prática forense, denominam-se ações reais ou pessoais, ou seja, pelo mesmo motivo que se emprega o nome de “ações possessórias” em vez de "ações por meio das quais se busca a proteção da posse”, não se podendo esquecer, todavia, que a ação, como direito constitucional, é sempre a mesma, não admitindo classificações. ${ }^{437}$

\footnotetext{
${ }^{433}$ CALMON DE PASSOS, José Joaquim. Teoria geral dos procedimentos especiais, p. 3.

${ }^{434}$ NERY JUNIOR, Nelson; NERY, Rosa Maria de Andrade. Código Civil comentado, p. 1389.

${ }^{435}$ COUTURE, Eduardo J. Fundamentos del Derecho Procesal Civil, p. 84.

${ }^{436}$ DINAMARCO, Cândido Rangel; GRINOVER, Ada Pellegrini; CINTRA, Antônio Carlos de Araújo. Teoria geral do processo, p. 284.

437 “[...] ação é palavra que não aceita classes ou adjetivações; ela não aceita quaisquer variações; ela não aceita qualquer gênero [...] A ação é sempre a mesma: o direito de provocar o Estado para prestar a tutela
} 
Para Astolpho Rezende, as ações possessórias não são ações reais, “e não o são porque reais são apenas as ações que nascem do jus in re, do direito real (domínio ou direito real sobre coisa alheia)". ${ }^{438}$ Nelson Nery Junior também afirma que a ação possessória não é real porque tem como causa de pedir a proteção da posse, "que não se encontra no rol taxativo dos direitos reais no direito positivo brasileiro". ${ }^{439} \mathrm{Na}$ mesma linha, Cassio Scarpinella Bueno sustenta que, “como a posse não é considerada, pelo art. 1.225 do Código Civil, como um direito real, não tem aplicação para as "ações possessórias” o disposto no caput e no $\S 1$. $^{\circ}$ do mesmo art. 10 ”. 440

É conhecido o posicionamento de Ovídio Baptista da Silva de que as ações reais não devem necessariamente estar relacionadas com direitos reais, devendo ser assim compreendidas as ações que tenham como objeto uma determinada coisa, em vez do cumprimento de uma obrigação. ${ }^{441}$ No entanto, tal entendimento certamente decorre do antigo texto do artigo 10 do Código de Processo Civil, que fazia referência às "ações que versem sobre bens imóveis”, tendo sido posteriormente substituído pela redação que dispôs sobre “direitos reais imobiliários”.

Contudo, parte dessa polêmica relativa à classificação da posse como direito real ou pessoal, e consequentemente sobre a classificação das ações possessórias como pessoal ou real, tornou-se estéril, visto que tal discussão, que teria o sentido prático de determinar se seria necessário ou não o consentimento do cônjuge para a propositura de ação possessória, por força da norma do artigo 10 do Código de Processo Civil, foi aniquilada com o advento do $\S 2 .^{\circ}$ desse dispositivo, incluído pela Lei 8.952/1994, que regulamentou que, “nas ações possessórias, a participação do cônjuge do autor ou do réu somente é indispensável nos casos de composse ou de ato por ambos praticado”.

jurisdicional e acompanhar a atuação do Estado até o fim” (BUENO, Cassio Scarpinella. Curso sistematizado de direito processual civil, v. 2, t. II, p. 395-396).

438 REZENDE, Astolpho. A posse e sua protecção, v. 2, p. 24.

439 NERY JUNIOR, Nelson; NERY, Rosa Maria de Andrade. Código de Processo Civil comentado, p. 244.

${ }^{440}$ BUENO, Cassio Scarpinella. Curso sistematizado de direito processual civil, v. 2, t. II, p. 75.

441 SILVA, Ovídio Araujo Batista das. Procedimentos especiais, p. 197. 
Nesse sentido, Darcy Bessone ${ }^{442}$ afirma que a modificação do artigo 10 do Código de Processo Civil, que dispensou a participação do cônjuge nas ações possessórias, teria excluído a natureza real da posse ou da ação possessória, pelo que não poderia prosperar a polêmica.

De fato, se havia margem para a polêmica, a inclusão do parágrafo segundo no artigo 10 do Código de Processo Civil retirou a sua razão de ser, porquanto essa alteração legislativa excluiu de maneira categórica os interditos do rol das ações reais, visto que o caput do artigo 10 dispõe que é necessário o consentimento do cônjuge para a propositura das ações que versem sobre direitos reais imobiliários, e no parágrafo segundo dispensa tal consentimento para as ações possessórias. ${ }^{443}$ A jurisprudência já encampou essa mudança legislativa, ${ }^{444}$ muito embora ainda se encontrem julgados que tratam os interditos como ações reais, mas possivelmente com o objetivo de fixar a competência no local da situação do imóvel.

Deve-se considerar, todavia, a opinião de Cândido Rangel Dinamarco que, ao comentar a competência prevista no artigo 95 do Código de Processo Civil, asseverou que a regra do artigo 10 do Código de Processo Civil não afasta o caráter real das ações possessórias, visto que se trata de dispositivo que tem o objetivo puramente pragmático de facilitar a propositura das demandas. ${ }^{445}$ Não concordamos com tal posicionamento, pois a

${ }^{442}$ BESSONE, Darcy. Da posse, p. 66.

443 "Outros doutrinadores de renome, como Darcy Bessone, concebem-na como direito obrigacional com argumentos que explicam a impossibilidade da oponibilidade do direito do possuidor contra todas as demais pessoas. A posse não foi expressamente elencada como direito real, quer pelo rol numerus clausus do art. 1.225 do Código Civil, quer em legislação esparsa. E não se olvide que a tipicidade é uma das características dos direitos reais. Ademais, o legislador teria definido a posse como direito obrigacional, sobremodo após a recente reforma do Código de processo Civil (Lei n. 8.952/94) que, no § 2. ${ }^{\circ}$ do art. 10 , dispensou a participação do cônjuge do autor e réu nas ações possessórias, exceto nas hipóteses de composse e atos por ambos praticados, postura esta incompatível com os direitos de natureza real imobiliária, que invariavelmente demandam a presença do cônjuge nos polos da relação jurídica" (FARIAS, Cristiano Chaves de; ROSENVALD, Nelson. Direitos reais, p. 33).

444 “Possessória - Ação de reintegração de posse - Outorga uxória e citação do cônjuge - Desnecessidade Ação de direito pessoal - Posse do imóvel pelo autor - Comprovação, inclusive por escritura de doação não revogada - Autor que, na qualidade de proprietário e possuidor, cuidou diariamente da falecida proprietária - Réu que invadiu a área após a morte da doadora - Esbulho caracterizado - Sentença mantida - Recurso improvido" (Apelação 9071539-73.2000.8.26.0000, 16. ${ }^{a}$ Câmara de Direito Privado do Tribunal de Justiça do Estado de São Paulo, Des. Rel. Cândido Alem, DJ 06.12.2011).

445 "Expressamente, o art. 95 do Código de Processo Civil inclui a posse entre os direitos reais cuja alegação na demanda imobiliária determina a competência absoluta do forum rei sitae. Põe-se ele, com isso, acima das conhecidas discussões doutrinárias sobre a natureza da posse - se direito real, se mero fato. Essa 
norma do artigo 10 do Código de Processo Civil não apenas resolve um problema prático, mas estabelece uma regra de natureza processual que confirma o caráter pessoal das ações possessórias - posicionamento adotado pela jurisprudência atual. ${ }^{446}$

Quanto à regra de competência disposta no artigo 95 do Código de Processo Civil, ${ }^{447}$ é corrente a afirmação de que, por se tratar de ação real, a reintegração de posse se submete a essa regra de competência. Esse é o entendimento do Superior Tribunal de Justiça acerca dessa matéria. ${ }^{448}$

Todavia, a competência ditada pelo referido dispositivo legal se aplica às ações possessórias que têm como objeto um bem imóvel não por se tratar a posse de direito real, mas sim para facilitar a tramitação do processo, que não seria efetivo e célere se se

colocação não é desmentida pelo art. 10, § 2. ${ }^{\circ}$, do Código de Processo Civil, pelo qual 'nas ações possessórias, a participação do cônjuge do autor ou do réu somente é indispensável nos casos de composse ou de atos por ambos praticados'. Tal dispositivo tem o objetivo puramente pragmático de facilitar a propositura das demandas a que se refere, limitando-se a isso a sua eficácia. Não colide com a regra de competência absoluta contida no art. 95” (DINAMARCO, Cândido Rangel. Instituições de direito processual civil, v. 1, p. 531).

446 "Possessória - Esbulho consistente na remoção de cerca lateral de servidão de passagem - Ato atribuído aos réus varões, não às suas esposas - Não há necessidade de consentimento conjugal para o ajuizamento de ação possessória - Não se trata de ação confessória de servidão, mas de ação possessória - Posse não é direito real - Incidência, ademais, do art. 10, § 2. ${ }^{\circ}$, do CPC - Preliminar rejeitada” (1343330400 SP, Rel. Álvaro Torres Júnior, j. 26.01.2009, 20. a Câmara de Direito Privado, publ. 13.02.2009). “Ação rescisória. Ação de reintegração de posse. Prequestionamento. Desnecessidade. Outorga. Nulidade não reconhecida. Violação a literal disposição de lei. Interpretação razoável. Não ocorrência. Pedido improcedente. Em se tratando de ação rescisória não se impõe o requisito do prequestionamento. A norma processual é clara ao impor a necessidade de consentimento do cônjuge nas ações reais, entretanto, pelo que se apreende do $\S$ 2. ${ }^{\circ}$, do art. 10, do Código de Processo Civil, em sede de ação possessória, 'não se tratando de ação real, dispensável é a vênia conjugal para propô-la'. 'Para que a ação rescisória fundada no art. 485, V, do CPC prospere, é necessário que a interpretação dada pelo decisum rescindendo seja de tal modo aberrante que viole o dispositivo legal em sua literalidade. Se, ao contrário, o acórdão rescindendo elege uma dentre as interpretações cabíveis, ainda que não seja a melhor, a ação rescisória não merece vingar, sob pena de tornar-se recurso ordinário com prazo de interposição de dois anos” (TJMG, Recurso 1.0000.05.4240403/0001, Rel. José Flávio de Almeida, j. 21.03.2007, publ. 04.05.2007).

447 “Art. 95. Nas ações fundadas em direito real sobre imóveis é competente o foro da situação da coisa. Pode o autor, entretanto, optar pelo foro do domicílio ou de eleição, não recaindo o litígio sobre direito de propriedade, vizinhança, servidão, posse, divisão e demarcação de terras e nunciação de obra nova.”

448 “Processual civil. Competência. Instalação de novas varas federais. Redistribuição de processos. Ação de reintegração de posse. Natureza real. Art. 95 do CPC. Competência absoluta. Foro de situação do imóvel. 1. A competência para as ações fundadas em direito real sobre bem imóvel - art. 95 do CPC é absoluta e, portanto, inderrogável, de modo a incidir o princípio do forum rei sitae, tornando-se inaplicável o princípio da perpetuatio jurisdictionis. 2. Nos termos do art. 87 do CPC, a superveniente criação de Vara Federal, situada no local do imóvel, desloca a competência para esse Juízo. 3. Hipótese em que a instalação posterior de vara federal no Município de Castanhal (local da situação do imóvel) deslocou a competência para julgamento da presente ação de reintegração de posse. Agravo regimental improvido” (AgRg REsp 1.281.850/PA, Rel. Min. Humberto Martins, DJ 13.12.2011). 
desenvolvesse em outra localidade que não a do imóvel perseguido. ${ }^{449}$ Considera-se equivocado, portanto, o entendimento apresentado pelo Superior Tribunal de Justiça de que as ações possessórias se submetem à regra de competência do artigo 95 do Código de Processo Civil por se tratar de ações de natureza real; submetem-se a essa norma porque têm como objeto um bem imóvel, e não se podem, a partir desse dispositivo, classificar como reais os interditos possessórios.

Mais acertado nos parece, assim, o entendimento de Antonio Carlos Marcato que, ao tratar do procedimento especial das ações possessórias, afirmou que

[...] o Código de Processo Civil não reconhece natureza real ao direito de posse, ao dispor no $\S 2 .^{\circ}$ de seu art. 10 , com todas as letras, que nas ações possessórias a participação do cônjuge da parte somente será indispensável nos casos de composse ou de atos por ambos praticados e em ambos a necessidade da participação do casal decorre não da natureza jurídica da posse, mas, sim, da comunhão de direitos ou de obrigações. ${ }^{450}$

Portanto, embora seja possível identificar na posse algumas das características dos direitos reais, o Código Civil não a relacionou expressamente no rol dos direitos reais, e, em sentido contrário, a disposição do artigo 10 do Código de Processo Civil classifica a posse como direito pessoal, ainda que não expressamente, e como pessoal a ação que tenha como fundamento a posse e sua proteção. ${ }^{451}$

449 “A determinação da competência em razão da situação da coisa, ou, mais precisamente, em razão da situação do imóvel, cria o chamado forum rei sitae, herança romana, da época imperial. Justifica-se pela evidente conveniência do andamento do processo no foro da situação do imóvel sobre que versar a lide e que se manifesta na diminuição de despesas e de tempo na prática de certos atos e por possibilitar ao juiz da causa o exame direto das coisas sobre que incidir a sua decisão. Com efeito, em quase todas as ações relativas a imóvel se produzem vistorias, que são provas de fatos ou circunstâncias inerentes a este, as quais não poucas vezes reclamam a presença do juiz. Demais, é aconselhar-se que, nessas ações, o juiz, 'a fim de se esclarecer sobre fato, que interesse à decisão da causa', se valha da chamada inspeção judicial e se locomova até o imóvel sempre que julgar isso necessário 'para melhor verificação ou interpretação dos fatos que deva observar' (Cod. Proc. Civil, arts. 440 e 442, n. I). O Código de Processo Civil de 1939 instituía o forum rei sitae para as ações relativas a imóvel, isto é, para as ações ditas imobiliárias. Restringiu o Código atual a competência daquele foro para as ações reais imobiliárias” (AMARAL SANTOS, Moacyr. Primeiras linhas de direito processual civil, v. 1, p. 199).

${ }^{450}$ MARCATO, Antônio Carlos. Procedimentos especiais, p. 140

451 "Não obstante a controvérsia doutrinária acerca da natureza jurídica da posse, esta Corte, relativamente a este aspecto, firmou-se no sentido de que tal ação tem natureza pessoal e, em decorrência, prescreve em vinte anos (v.g., REsp 331.779/SP, Rel. Min. Sálvio de Figueiredo, DJ 04.02.2002; REsp 93.308/RS, Rel. 


\subsection{Princípio da fungibilidade}

O artigo 920 do Código de Processo Civil trata da aplicação do princípio da fungibilidade nos interditos possessórios, dispondo, ainda que com terminologia pouco adequada, que a propositura de uma “ação possessória em vez de outra” não impedirá que o juiz conheça do pedido e conceda a tutela jurisdicional adequada. O Código de Processo Civil de 1939 já previa o princípio da fungibilidade das ações possessórias, mas, considerando que a referida norma estava localizada no Capítulo I do Título XIII do Livro IV (art. 375), destinado às ações de manutenção e reintegração de posse, pairava a dúvida quanto à sua aplicação ao interdito proibitório, que vinha regulamentado no capítulo II, mas a polêmica foi extinta com o advento do Código de $1973 .{ }^{452}$

Como mencionado anteriormente, as ofensas à posse variam da ameaça à violação máxima, que é o esbulho, e essa variação é dotada de um dinamismo que exige certa flexibilidade quanto à fixação dos elementos objetivos da ação, pois, se o juiz estivesse adstrito ao pedido apresentado na inicial, na maioria das vezes seria inviável a efetiva prestação jurisdicional, porquanto a concessão da tutela para afastar a turbação poderia ser inútil se fosse agravada a violação com a concretização do esbulho, ou vice-versa (o esbulho ser substituído por simples turbação, por exemplo). ${ }^{453}$

Ou seja, a regra da fungibilidade nas ações possessórias importa em não vincular o juiz ao pedido formulado pelo autor da demanda, tornando possível que se conceda a tutela jurisdicional sem a necessidade de aditar a inicial, ou aproveitando o processo já iniciado, caso já tenha sido citado o réu no momento da modificação dos fatos (art. 264, CPC) com a evolução de uma violação menos grave para outra mais grave e vice-versa.

Min. Ruy Rosado de Aguiar, DJ 1º.07.1999; REsp 40.721/MG, Rel. Min. Nilson Naves, DJ 1º.08.1994,

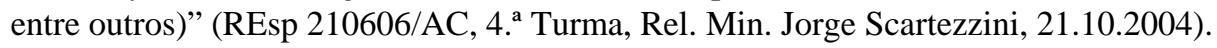

452 SANTOS, Ernane Fidelis dos. Dos procedimentos especiais do Código de Processo Civil, p. 103.

${ }^{453}$ Nesse sentido: “A dinâmica das situações de direito material determina que nas ações possessórias o juiz não esteja adstrito, vinculado ao pedido da parte. Ocorre que uma situação de mera ameaça ao exercício do direito de posse pode, rapidamente, converter-se em uma efetiva violação desse direito. Assim, se o juiz estivesse adstrito ao pedido formulado na ação de interdito proibitório, não poderia, na mesma demanda, sem eventual aditamento da inicial, determinar uma providencia reintegratória” (DESTEFENNI, Marcos. Curso de processo civil, v. 3, p. 386). 
Sabe-se que os artigos 128 e 460 do Código de Processo Civil impõem limites à decisão judicial, de modo a impedir que seja proferida sentença de procedência diversa daquela pleiteada pelo autor, e que o artigo 264 do mesmo Codex impede a alteração do pedido e da causa de pedir depois de feita a citação do réu sem o seu consentimento, e em hipótese alguma após o saneamento do feito.

Entretanto, a regra da fungibilidade nas possessórias cria exceção que visa exatamente à flexibilização dessas normas, que andariam em descompasso com a dinâmica dos fatos relacionados à violação da posse. ${ }^{454}$ Parte da doutrina entende, todavia, que não há exceção ao princípio da congruência na aplicação da regra da fungibilidade nas ações possessórias, o que se conclui a partir do entendimento de que os três interditos teriam, na verdade, o mesmo pedido, qual seja o de proteção possessória, e a mesma causa petendi a violação à situação da posse.

A ideia dessa generalização dos elementos objetivos da ação nos interditos possessórios foi apresentada por Pontes de Miranda, ${ }^{455}$ e seguida pela maior parte dos doutrinadores, como Antonio Carlos Marcato, ${ }^{456}$ Ernane Fidelis dos Santos ${ }^{457}$ e Adroaldo Furtado Fabrício, e este último, ao admitir essa identidade de causa de pedir e de pedido nas ações possessórias, chega a afirmar que, “a rigor, há uma só ação possessória, com variantes determinadas pelas condições de fato”. ${ }^{458}$ Cláudia Cimardi, no mesmo sentido,

454 "Poderá também haver adaptação no curso do processo caso se alterem as circunstâncias fáticas, sem que se fale em sentença extra petita" (WAMBIER, Luiz Rodrigues; TALAMINI, Eduardo. Curso avançado de processo civil, p. 272).

455 "Em verdade, com a letra da lei, o sistema jurídico fez ler-se todo o pedido de manutenção de posse, ou de reintegração de posse, como pedido de proteção possessória. 'Proteja-me', há de ser entendido, onde apenas se diga 'Mantenha-me na posse', ou 'Reintegre-me na posse'” (PONTES DE MIRANDA, Francisco Cavalcanti. Comentários ao Código de Processo Civil, t. XIII, p. 162).

456 "Importa, pois, para a concessão da tutela adequada a que alude o art. 920, que a causa de pedir seja, genericamente, a ofensa ao direito de posse do autor e, ainda, que este tenha postulado a concessão de tutela possessória” (MARCATO, Antônio Carlos. Procedimentos especiais, p. 142).

${ }^{457}$ SANTOS, Ernane Fidelis dos. Dos procedimentos do Código de Processo Civil, v. 6, p. 103.

458 “O petitum é sempre pedido de proteção possessória, embora esta possa assumir mais de uma forma e a indicada pelo autor não seja a cabível. O binômio 'ofensa à posse-proteção possessória' é sempre o mesmo, e a variação do segundo termo corresponde a diferenças de extensão, não de essência, do primeiro. Pode-se mesmo afirmar que, a rigor, há uma só ação possessória, com variantes determinadas pelas condições de fato" (FABRÍCIO, Adroaldo Furtado. Comentários ao Código de Processo Civil, v. 8, t. III, p. 430). 
sustenta expressamente que a fungibilidade das possessórias não representa exceção à regra da correlação entre pedido e sentença. ${ }^{459}$

Não concordamos com o posicionamento desses autores no tocante à generalização dos elementos objetivos nas ações possessórias. As ações de reintegração e de manutenção de posse, assim como o interdito proibitório, têm causas de pedir e pedidos diversos - o que inclusive é ressaltado pelos citados doutrinadores -, não obstante o que se pretenda, genericamente, é a proteção da posse, assim como em qualquer ação de natureza condenatória o que se deseja, genericamente, é a condenação em razão da violação de um direito.

Buscam-se em cada um dos interditos possessórios provimentos diversos, que se fundamentam em causas de pedir variadas. Na ação de manutenção da posse, o autor reclama da posse turbada - e não perdida, portanto - e pleiteia que o Judiciário imponha uma obrigação de não fazer; já na ação de reintegração de posse o autor que perdeu a posse pelo esbulho pede a sua reintegração, ou, mais precisamente, a restituição da coisa esbulhada.

É certo que essa generalização tem como objetivo a simplificação do processo, visando ao princípio da instrumentalidade e da efetividade, ${ }^{460}$ para que, nas ações possessórias, a tutela adequada não deixe de ser concedida por apego exagerado e irracional à forma prescrita na lei, dado que a causae petendi e o pedido se aproximam sobremaneira nos interditos por se tratar de violação e proteção da posse.

Contudo, compreender corretamente a variação das causas de pedir e dos pedidos nas ações possessórias não impede que se outorgue corretamente a tutela jurisdicional.

\footnotetext{
459 "Na esteira dos dois últimos ensinamentos supraesposados, entendemos que o art. 920 do CPC não se apresenta como exceção à mencionada regra, contida nos arts. 128 e 460 do CPC. Isto porque, conforme anteriormente analisado, as causas de pedir que diferenciam as ações possessórias, apesar de materialmente diversas, pois diferentes as espécies de ofensa conforme sua extensão - esbulho, turbação e ameaça -, substancialmente correlacionam-se a um só fundamento, qual seja uma agressão à posse. Por conseguinte, os pedidos a elas correspondentes - reintegração, manutenção e proibição consubstanciam-se em um único: o da proteção da posse” (CIMARDI, Cláudia Aparecida. Proteção processual da posse, p. 166).

460 "O princípio da fungibilidade das possessórias contribui para tornar mais efetiva a tutela da posse" (ARRUDA ALVIM; ASSIS, Araken de; ALVIM, Eduardo Arruda. Comentários ao Código de Processo Civil, p. 1832).
} 
Afinal, como ressaltou Ovídio A. Baptista da Silva, apesar de o art. 920 do CPC consagrar o princípio da fungibilidade das ações possessórias, é relevante identificar os casos em que se tenham dado perda, moléstia ou ameaça, ${ }^{461}$ sob pena de, em nome da efetividade e da instrumentalidade, abandonar-se a técnica processual - o que não é o objetivo desses princípios.

Assim, sob a ótica da teoria da classificação dos provimentos judiciais - tema que será abordado com mais profundidade adiante (item 4.10.2) -, não há como sustentar que esses elementos da ação são os mesmos nos três interditos possessórios, pelo que se conclui que a aplicação da fungibilidade é sim exceção à regra da correlação entre causa de pedir, pedido e sentença. ${ }^{462}$

A necessidade de adaptação do pedido e da causa de pedir pelo juiz pode decorrer de diversas causas, quais sejam a (i) incorreta narração dos fatos pelo autor, a (ii) qualificação jurídica errônea dos fatos apresentados corretamente e a (iii) variação dos fatos após o ajuizamento da ação possessória. Ou seja, o autor pode narrar erroneamente os fatos, afirmando que perdeu a posse, quando, na verdade, foi apenas turbado, o que configuraria a primeira situação; pode, também, qualificar equivocadamente os fatos, chamando de turbação o que é esbulho, e formular pedido errado; ainda, mesmo não havendo erro do autor, a necessidade de adaptação do pedido pode decorrer de variação dos fatos. Assevera Adroaldo Furtado Fabrício que, para qualquer dessas situações, deve

461 SILVA, Ovídio A. Baptista da. Curso de Processo Civil, v. 1, t. II, p. 182.

462 Nesse sentido: “O que a lei faz, no art. 920, é liberar o juiz dos limites impostos no art. 460 do Código de Processo Civil” (MONTEIRO, João Batista. Ação de reintegração de posse, p. 81). "Como soa evidente, o princípio da fungibilidade das ações possessórias conduz a uma atenuação do rigor da regra da adstrição do juiz ao pedido, estampada nos arts. 128 e 460” (ARRUDA ALVIM; ASSIS, Araken de; ALVIM, Eduardo Arruda. Comentários ao Código de Processo Civil, p. 1832). GRECO FILHO, Vicente. Direito processual civil, v. 3, p. 274. “[...] o art. 920 do Código de Processo Civil constitui uma exceção à regra da correlação entre o pedido e a sentença (arts. 128 e 460 do CPC)” (TEIXEIRA, Guilherme Freire de Barros. Teoria do princípio da fungibilidade, p. 195). “A regra da fungibilidade constitui exceção ao princípio geral estabelecido nos CPC 128 e 460, de que deve haver correlação entre causa de pedir, pedido e sentença” (NERY JUNIOR, Nelson; NERY, Rosa Maria de Andrade Nery. Código de Processo Civil comentado, p. 1389). 
incidir a fungibilidade, "autorizando e obrigando o juiz a prestar proteção possessória adequada, embora diversa da pedida” ${ }^{463}$ - posicionamento unânime na doutrina.

Quanto aos limites de incidência da norma do artigo 920 do Código de Processo Civil, a doutrina é assente em afirmar que sua aplicação se restringe às ações possessórias, não se estendendo às denominadas “ações petitórias”, como é o caso da ação reivindicatória. É esse o posicionamento de Nelson Nery Junior, ${ }^{464}$ Adroaldo Furtado Fabrício, ${ }^{465}$ Marinoni, ${ }^{466}$ Arruda Alvim, ${ }^{467}$ Vicente Greco Filho ${ }^{468}$ e Clito Fornaciari Junior, ${ }^{469}$ com o qual concordamos.

No entanto, é preciso diferenciar fungibilidade de causa de pedir e de pedido, que, em verdade, é o que decorre da norma do artigo 920 do Código de Processo Civil, de adaptação do procedimento equivocadamente indicado pelo autor ou, ainda, irrelevância do nome atribuído ao remédio processual, o que usualmente se denomina “rótulo da ação”.

O equívoco na escolha de procedimento pode ser corrigido com fundamento no artigo 250 do Código de Processo Civil, que prevê a anulação dos atos praticados no

${ }^{463}$ FABRíCIO, Adroaldo Furtado. Comentários ao Código de Processo Civil, v. 8, t. III, p. 429.

464 “[...] não poderá o juiz converter a ação possessória em reivindicatória ou em ação de imissão na posse, que, como já se frisou, são ações petitórias” (NERY JUNIOR, Nelson; NERY, Rosa Maria de Andrade. Código de Processo Civil comentado, p. 1399).

${ }^{465}$ FABRÍCIO, Adroaldo Furtado. Comentários ao Código de Processo Civil, v. 8, t. III, p. 432.

466 “A norma expressa regra da fungibilidade entre as tutelas possessórias (reintegração de posse, manutenção de posse e interdito proibitório), estando descartadas deste âmbito, porém, as ações reivindicatória e de imissão de posse, que não são possessórias, mas sim petitórias (fundadas no domínio)” (MARINONI, Luiz Guilherme; ARENHART, Sérgio Cruz. Procedimentos especiais, p. 93).

467 "Não há fungibilidade entre ações possessórias e ações petitórias, entre as quais se encarta a ação de imissão na posse" (ARRUDA ALVIM; ASSIS, Araken de; ALVIM, Eduardo Arruda. Comentários ao Código de Processo Civil, p. 1833).

468 "Essa regra, porém, como exceção aos princípios consagrados nos arts. 459 e 460 (proibição de julgamento extra petita), deve ser interpretada estritamente, não admitindo extensão analógica para outros casos. Ela se refere exclusivamente à fungibilidade entre as possessórias; não é aplicável, por exemplo, entre o pedido possessório e o petitório. A propositura de possessória quando caberia reivindicatória, ou vice-versa, leva à carência da ação por falta de interesse processual adequado. Não há possibilidade de o juiz aceitar uma pela outra” (GRECO FILHO, Vicente. Direito processual civil, v. 3, p. 274).

${ }^{469}$ Obviamente, como se cuida de regra excepcional, sua aplicação deve ser feita restritivamente, levando-se em conta somente as três medidas, não se permitindo a utilização do preceito para a conversão de ação possessória em reivindicatória, ou, ainda, para conferir imissão de posse, a quem não a tem” (FORNACIARI JUNIOR, Clito. O procedimento das chamadas ações possessórias. In: CAHALI, Yussef Said (Coord.). Posse e propriedade, p. 187). 
processo com erro de forma quando não puderem ser aproveitados, ou seja, no caso de escolha do procedimento inadequado pode ser feita a conversão para correção do erro. ${ }^{470}$

Neste caso, ressalta Guilherme Freire de Barros Teixeira, “a demanda ajuizada pela parte continua a ser a mesma, mantendo-se inalterados o pedido e a causa de pedir, modificando-se somente o rito a ser seguido”, e não tendo sido substituída uma medida por outra, mas simplesmente realizada uma correção pelo juiz, "não se cogita da aplicação do princípio da fungibilidade”. ${ }^{471}$ Situação diversa, segundo o autor, seria a da possibilidade de empregar um tipo de procedimento quando houver previsão de um rito determinado, e neste caso estaria presente a fungibilidade de procedimentos.

Da mesma forma, é irrelevante o nome atribuído ao remédio processual, importando sim a identificação da demanda pelos elementos objetivos: causa de pedir e pedido.

Assim, se apesar de rotular sua pretensão de ação de reintegração de posse o autor fundamenta seu pedido de proteção possessória no domínio, tem-se, na verdade, a ação reivindicatória. Isto é, embora tenha formulado, com fundamento no direito de propriedade, pedido de restituição do bem que se encontra em poder de terceiro, o autor atribuiu ao remédio judicial o nome de “ação de reintegração de posse”. Diante disso, nada impede que o juiz, corrigindo o procedimento - se tiver sido ajuizado pelo rito especial, pois, caso o esbulho tenha ocorrido há mais de ano e dia, o procedimento já será o comum, igual ao que deverá seguir a ação reivindicatória - e ignorando o “rótulo” equivocado, conceda o provimento pleiteado.

A jurisprudência do Superior Tribunal de Justiça tem firmado esse entendimento, reconhecendo que, não obstante o "rótulo" empregado pelo autor, o que importa são os elementos da ação. ${ }^{472}$ Alguns doutrinadores, sensíveis e atentos a essa questão, já se

\footnotetext{
470 TEIXEIRA, Guilherme Freire de Barros. Teoria do princípio da fungibilidade, p. 204.

${ }^{471}$ Idem, ibidem, p. 206.

472 "Processo civil. Ação de imissão de posse. Denominação irrelevante. Pedido possessório. CPC, arts. 245, 250 e 920. Usufruto. Norma legal. Recurso provido. I - Para a ciência processual, o rótulo que se dá a causa e irrelevante, atendendo apenas a conveniências de ordem prática. Essa denominação da ação consiste em resquício da teoria civilista sobre a natureza jurídica da ação. II - Inviável em linha de princípio a conversão da ação de imissão na posse, de natureza petitória, em ação possessória, prove-se,
} 
manifestaram no mesmo sentido, a exemplo de Cláudia Cimardi ${ }^{473}$ e Sidney Amendoeira Jr., ${ }^{474}$ que, apesar de reconhecer que não poderia o juiz "estender essa fungibilidade para as ações petitórias de forma irrestrita”, admite que em certas situações isso é possível.

O mencionado autor entende que há fungibilidade entre o interdito possessório de reintegração de posse e a ação de despejo, porquanto haveria alteração apenas do nomen iuris, visto que seriam idênticas as causas de pedir e os pedidos de ambas as medidas judiciais - esbulho e retomada da coisa. ${ }^{475}$ Sustenta ainda o autor que haveria fungibilidade entre as ações possessórias e os embargos de terceiro, com o que não se concorda, pois, como será demonstrado adiante (item 5.3), diferenciam-se os embargos de terceiro das ações possessórias típicas em razão da exigência, nestas, de ilicitude do esbulho ou da turbação, enquanto, por meio daquele remédio processual, a restrição ou privação da posse estarão amparadas em decisão judicial, o que lhes retira a ilicitude.

O que importa é que, em relação às ações possessórias e a reivindicatória, essa sutil diferença entre a fungibilidade e a admissão da demanda posta corretamente em seus elementos, mas com erro de rótulo e de procedimento, é ignorada pela maior parte da doutrina, e também não percebida pela maioria dos tribunais estaduais. ${ }^{476}$

no entanto, o especial na medida em que no caso, a pretensão deduzida pelo pai usufrutuário foi induvidosamente de reintegração na posse” (REsp 32143/PA, 4. ${ }^{\text {a }}$ Turma, Min. Sálvio de Figueiredo Teixeira, DJ 27.06.1996). "Reivindicatória. A lide há de ser julgada consoante a causa de pedir e o pedido, não relevando o rotulo dado pelo autor. Se esse pretende a posse com base no domínio o pleito e petitório, ainda que indevidamente qualificado de possessório” (REsp 45421/SP, 3. a Turma, Min. Nilson Naves, DJ 24.02.1997). "Reintegratória e reivindicatória. A natureza da pretensão deduzida não se há de encontrar no rótulo eleito pelo autor. Relevam pedido e causa de pedir. Se se pede a posse no domínio o pleito se qualifica como petitório” (REsp 37187/RJ, 3. Turma, Min. Eduardo Ribeiro, DJ 04.04.1995).

473 “E ainda que ajuizada ação reivindicatória atribuindo-lhe o nome de possessória, não há impedimento para que o pedido petitório seja apreciado como tal, pois os elementos que a identificam são a pretensão à posse, em função da propriedade” (CIMARDI, Cláudia Aparecida. Proteção processual da posse, p. 93).

${ }^{474}$ AMENDOEIRA JR., Sidnei. Fungibilidade de meios, p. 144-145.

475 Idem, ibidem, p. 146.

476 “Ação reivindicatória. Proteção de posse. Ação possessória. Fungibilidade. Impossibilidade. Não se aplicam as disposições do artigo 920 do Código de Processo Civil, no que tange à fungibilidade das ações possessórias, quando a parte propõe ação reivindicatória, dita como petitória, no lugar de ação que lhe resguarde direito de posse sobre imóvel” (TJMG, Recurso 1.0702.05.197011-0/0011, Rel. Otávio Portes, j. 17.10.2007). "Imissão de posse. Pleito cumulado com demolição da construção julgado extinto, sem resolução do mérito, por falta de interesse de agir. Cabimento. Apelantes que pretendem a retomada do imóvel de sua propriedade que foi invadido e ocupado indevidamente pelo réu. Via eleita inadequada por se tratar de ação dominial. Caso típico de proteção possessória. Impossibilidade de aplicação do princípio da fungibilidade. Restrição de cabimento às ações possessórias entre si. Recurso desprovido” (TJSP, 
Assim, admite-se que não pode haver fungibilidade entre as ações possessórias e a reivindicatória se o autor, afirmando ser possuidor, sucumbe na prova deste fato, mesmo sendo o proprietário da coisa. Deve-se perceber, porém, que, se o autor propõe demanda alegando ser proprietário e pedindo a restituição da coisa, ainda que empregue o rótulo de ação de reintegração de posse, nada impede que lhe seja concedida a tutela adequada.

Não se trata de converter ação possessória em petitória, mas simplesmente de identificar corretamente a demanda, por meio de seus elementos, ignorando o "rótulo" empregado e determinando a utilização do procedimento adequado, se tiver sido indicado o especial. ${ }^{477}$ Com essa distinção, inúmeras sentenças de extinção poderiam ser evitadas, bastando que o juiz identifique a pretensão do autor e seu fundamento para, se for o caso, fazer as adaptações necessárias no início do processo, providência absolutamente legal e que não depende de aplicação do princípio da fungibilidade. Entretanto, mesmo que se entenda que essa providência resultaria da aplicação do princípio da fungibilidade, ainda assim seria possível o aproveitamento do processo. ${ }^{478}$

Questiona-se, ainda, qual o limite temporal para aplicação da fungibilidade nas ações possessórias, se apenas no início do processo, ou se também no momento da sentença e até mesmo em grau recursal. Segundo Adroaldo Furtado Fabrício, “pode ocorrer já na decisão liminar e provisória ditada segundo o art. 928, na sentença definitiva ou ainda na fase recursal, caso em que, naturalmente, a correção será introduzida pelo juízo de

Recurso 9088029-05.2002.8.26.0000, 9. a Câmara de Direito Privado, Rel. Galdino Toledo Júnior, j. 23.08.2011). "Reintegração de posse. Requisitos não preenchidos. Adaptação. Reivindicatória. Inaplicabilidade do princípio da fungibilidade. É inaplicável o princípio da fungibilidade, inerente às possessórias, a fim de converter a reintegração de posse em reivindicatória, porquanto diversa a natureza das ações e de suas respectivas causas de pedir” (TJMG, Recurso 1.0480.04.058508-9/0021, Rel. José Antônio Braga, j. 03.02.2009).

477 “Mas o juiz não pode, de ofício, converter ação reivindicatória em ação possessória (JTJ 176/212). Diversa é a situação se o autor mover, em realidade, ação possessória, rotulando-a de reivindicatória, ou vice-versa” (NEGRÃO, Theotonio. Código de Processo Civil, p. 987).

478 “A fungibilidade, todavia não deve ficar limitada às hipóteses previstas em lei ou consagradas na doutrina e na jurisprudência. É de ser considerado princípio geral do sistema processual, tanto quanto o da instrumentalidade das formas, de que ele constitui mera decorrência lógica” (BEDAQUE, José Roberto dos Santos. Efetividade do processo e técnica processual, p. 119). 
segundo grau” ${ }^{479}$ No mesmo sentido, Clito Fornaciari Junior sustenta que “a utilização do preceito pode ocorrer até mesmo na fase recursal, sempre em vista da evolução dos fatos”.

Segundo parte da doutrina e da jurisprudência, é possível até mesmo que a aplicação da fungibilidade ocorra no cumprimento do mandado, após o trânsito em julgado da sentença, ${ }^{480}$ momento em que o juiz, que concedeu tutela para afastar a turbação em ação de manutenção de posse, poderá determinar a reintegração de posse caso tenha havido alteração dos fatos, sendo desnecessária a propositura de nova demanda possessória. ${ }^{481}$

Cláudia Cimardi entende que, verificado o trânsito em julgado, não mais seria possível aplicar a regra da fungibilidade. ${ }^{482}$ No entanto, ao que nos parece, a situação narrada não decorre da utilização da fungibilidade para modificação da sentença já passada em julgado, mas simplesmente de cumprimento do provimento não respeitado pelo réu, pois, se foi outorgada proteção contra a turbação, haverá condenação ao cumprimento de obrigação de não fazer, consistente em não turbar a posse do autor. Logo, se o réu, em desobediência ao comando judicial, turba ou esbulha a posse, deverá ser repelido por meio do cumprimento da sentença, que acarretará a expedição do competente mandado de manutenção ou reintegração de posse.

Também pode ser invocada a fungibilidade nas ações possessórias intentadas além do prazo de ano e dia da ofensa à posse, ou seja, nas hipóteses de proteção da posse por meio do procedimento ordinário, ${ }^{483}$ visto que esse princípio positivado pelo legislador não

${ }^{479}$ FABRíCIO, Adroaldo Furtado. Comentários ao Código de Processo Civil, v. 8, t. III, p. 431-432.

480 “Caso de posse. Procedência. Proteção possessória. Fungibilidade. Alteração na situação de fato. Irrelevância. Cumprimento do julgado. Provimento do recurso. Aos interditos possessórios (de manutenção, reintegração ou proibitório) se aplica o princípio da fungibilidade ou conversibilidade (art. 920 do CPC), e se a proteção possessória foi deferida, inadmissível é o ajuizamento de outra ação, para buscar a mesma proteção possessória, que e única, variando apenas em sua extensão. Procedente a demanda de manutenção de posse, após o trânsito em julgado da sentença deve ser cumprido o julgado, com a manutenção dos autores na posse do imóvel, e reintegração em parcela menor da área objeto da proteção concedida. Agravo de instrumento provido" (TJPR, Agravo de Instrumento 0121330-5, 5. ${ }^{\text {a }}$ Câmara Cível, Rel. Denise Martins Arruda, j. 26.08.1998).

${ }^{481}$ SANTOS, Nelton dos. In: MARCATO, Antônio Carlos (Coord.). Código de Processo Civil interpretado, p. 2402.

${ }^{482}$ CIMARDI, Cláudia Aparecida. Proteção processual da posse, p. 168.

483 “Contudo, em termos estruturais, os procedimentos praticamente se equivalem, não sendo desarrazoado concluir pela possibilidade de aplicação da fungibilidade aos procedimentos ordinário e especial, 
é restrito ao procedimento especial, mas sim às ações possessórias, que guardam tal caráter mesmo que ajuizadas após o decurso do período de ano e dia.

\subsection{Liminar}

Ao longo dos tópicos seguintes serão apresentados aspectos diversos sobre a liminar das ações possessórias, iniciando-se por uma breve noção histórica acerca do tema e examinando questões relativas à sua natureza, à possibilidade de sua concessão no procedimento comum com fundamento na regra geral da tutela antecipada e ao momento de sua concessão.

\subsubsection{Contexto histórico}

À proteção da posse sempre foi dispensado tratamento especial, sendo característica marcante desde o direito romano até as Ordenações do Reino e as legislações mais modernas a disponibilização de um procedimento célere para a solução dos conflitos possessórios.

No direito romano, como já visto, a proteção da posse era concedida por meio do interdictum, que, na concepção de Thomas Marky, “era um processo especial baseado no poder de mando do pretor e caracterizado pela maior rapidez e simplicidade em comparação com as ações do processo formular”. ${ }^{484}$ Em outras palavras, o interdito, na concepção romana, consistia em uma ordem proferida numa situação de urgência (interim dicuntum) entre duas pessoas (inter dictum) e dotada de provisoriedade, e por isso é possível estabelecer uma comparação entre o interdicto romano e o instituto da tutela antecipada que hoje conhecemos. ${ }^{485}$

principalmente quando equivocadamente utilizado aquele quando seria cabível este" (TEIXEIRA, Guilherme Freire Barros. Teoria do princípio da fungibilidade. p. 202).

${ }^{484}$ MARKY, Thomas Marky. Curso elementar de direito romano, p. 90.

485 “[...] os interditos possessórios representados pelas liminares em ações possessórias são os casos mais antigos de antecipação que o direito consagra em sua história bimilenar” (DINAMARCO, Cândido Rangel. Fundamentos do processo civil moderno, v.2, p. 1532). 
E tradicionalmente se relaciona à proteção liminar possessória o prazo de ano e dia, que encontra raízes no direito romano e, também, no direito germânico medieval. Segundo Fábio Caldas de Araújo, no direito romano, havia o prazo de ano e dia, para o exercício do interdito retinendae utrubi, que se destinava à proteção da turbação de bens móveis. ${ }^{486}$ E do direito germânico medieval vem o instituto da Gewere, que, apesar da divergência doutrinária, pode ser comparada, porém não equiparada, ${ }^{487}$ com a posse romana; se a Gewere perdurasse pelo prazo de ano e dia, viabilizaria a aquisição da rechte Gewere, 488 que, embora "não se confunda com a usucapio, tem, no direito germânico, a mesma importância de que desfrutava o usucapião do direito romano". 489

Assevera Guilherme Braga da Cruz que aos poucos foi se firmando a tendência de considerar a posse de mais de ano e dia uma posse prescrita, que, apesar de não conduzir à propriedade e não fazer caducar a ação de reivindicação, deixava de conferir ao possuidor o direito de recorrer à protecção interdital. E conclui o autor: "é nesse sentido - através duma evolução que seria impossível descrever aqui -, que a posse se ano e dia consegue

${ }^{486}$ ARAÚJO, Fábio Caldas. Posse, p. 85.

487 “.... por muito tempo foi a Gewere tida pelos juristas alemães como o equivalente da posse romana no direito germânico medieval, razão por que era considerada instituto extinto e apenas digno de curiosidade histórica. Foi a obra de Savigny que, caracterizando a posse romana como senhoria física sobre a coisa, despertou a atenção da doutrina alemã para a Gewere, pois, ocorrendo esta em várias hipóteses em que não havia esse poder, ficou evidenciado que não existia a equivalência”; "Note-se que, no direito romano vulgar (que, na época pós-clássica, é o direito romano vivo, aplicado na prática, adaptado às necessidade da vida, em face do direito elaborado, técnico, que é o direito oficial - o direito escrito -, estando para este como o latim vulgar está para o latim literário), a possessio e a Gewere apresentaram várias semelhanças, postas em relevo por Levy, West Roman Vulgar Law - The Law of Property, p. 96 a 99)" (MOREIRA ALVES, José Carlos. Posse. Evolução histórica, p. 75 e 313). No mesmo sentido: "La Gewere ha, dunque, quale punto di contato ed elemento comune ala possessio ila rapporto com la cosa, la relazione effeetiva com la coisa. Questa relazione, però, nella Gewere non puó prescindere dal titolo, perché essa stessa ne costituisce il titlo" (DIURNI, Giovanni. Verbete: "la Gewere”, Enciclopedia del Diritto, v. 34, p. 474).

${ }^{488}$ Astolpho Rezende afirmou que "a Gewere germânica não era a posse”, e sim que ela compreendia dois graus distintos, quais sejam, a simples detenção da coisa que, para os bens móveis, era chamada a simples Gewere e, no segundo, em relação aos bens imóveis, para os quais a simples detenção não era suficiente, a posse com motivo jurídico (justo título) era denominada rechte Gewere; "neste caso a ação era realmente fundada na posse, mas na justa possessio, o que a transformava radicalmente, e fazia dela uma ação petitória” (REZENDE, Astolpho. A posse e sua protecção, v. 2, p. 439).

${ }^{489}$ MOREIRA ALVES, José Carlos. Posse. Evolução histórica, p. 91. 
projetar-se ao longo de toda a história do direito português até os nossos dias, deixando marcada ainda a sua presença no artigo 489 do nosso Código Civil”. 490

Assim, as Ordenações Afonsinas conservaram o instituto da posse de ano e dia, que passou a ser utilizado como critério de definição do foro em que seria julgado o processo, de acordo com o Livro III, Título CXVI, dispondo que o possuidor poderia se defender perante o Juiz de seu foro se estivesse na posse do bem por mais de ano e dia, e perante o Juiz do foro da coisa se sua posse não tivesse completado esse prazo. ${ }^{491}$

Com o mesmo sentido, permanece o instituto no direito brasileiro. O Código Civil de 1916 dispôs sobre a posse de ano e dia em seu artigo 508, ${ }^{492}$ e tal previsão também constou nos Códigos de Processo Civil de $1939^{493}$ e de $1973^{494}$ como requisito para a concessão da liminar nas possessórias, motivo pelo qual a distinção entre posse nova e posse velha assumiu relevância no direito brasileiro.

Muito embora a previsão do Código Civil de 1916 não tenha sido recepcionada pelo atual Código, a permanência da distinção entre “posse nova” e "posse velha” no Código de Processo Civil mantém a sua condição de requisito para a concessão da medida

${ }^{490}$ CRUZ, Guilherme Braga da. A posse de ano e dia no direito hispânico medieval, Boletim da Faculdade de Direito, Universidade de Coimbra, v. 25, p. 28, 1949. Disponível em: $<$ http://www.uc.pt/ciuc/fduc/galeria_retratos/braga_cruz/pdf/doutrina_bc_vol_XXV_1949.pdf>.

491 “[...] que o possuidor da couza depois do anno e dia, contado daquelle dia que a começou de possuir, for por Ella demandado, nom será esse possuidor theúdo responder por ella, salvo perante os Juízes de seu foro; e se elle por Ella for demandado ante do anno e dia, em tal caso, ainda que a cousa estê em outro Luguar, e nom em aquelle, onde o possuidor he morador, será theudo responder por ella perante o Juiz de seu foro, ou perante o Juiz daquelle Lugar, honde essa couza estever, efor afsy *theuda* (a) honde mais aprovér ao Autor de fazer essa damanda” (Livro III, Título CXVI).

492 "Art. 508. Se a posse for de mais de ano e dia, o possuidor será mantido sumariamente, até ser convencido pelos meios ordinários.”

493 “Art. 371. Si a turbação ou violência datar de menos de ano e dia, o autor poderá requerer mandado de manutenção ou de reintegração initio litis, provando, desde logo:

I - a sua posse;

II - a turbação ou violência praticada pelo réu;

III - a data da turbação ou violência;

IV - a continuação da posse, embora turbada, na ação de manutenção, e a perda da posse, na ação de reintegração.”

494 “Art. 924. Regem o procedimento de manutenção e de reintegração de posse as normas da seção seguinte, quando intentado dentro de ano e dia da turbação ou do esbulho; passado esse prazo, será ordinário, não perdendo, contudo, o caráter possessório.” 
liminar, segundo o regramento do procedimento especial das ações possessórias, ${ }^{495}$ como já demonstrado anteriormente (item 4.5).

\subsubsection{Natureza da liminar das ações possessórias}

Visando à tão aclamada e indispensável efetividade do processo, o legislador vem buscando tutelas diferenciadas que objetivam melhor adaptá-lo às relações de direito material, para que se possa entregar em menor tempo o bem da vida pretendido. Nas palavras de José Roberto dos Santos Bedaque, tutelas diferenciadas são “modalidades de tutelas jurisdicionais dotadas de mecanismos especiais, destinados a proporcionar efetividade ao processo, uma vez que as formas tradicionais de tutela já não mais atendem as necessidades do direito material”. 496

Segundo o difundido ensinamento de Andrea Proto Pisani, a tutela jurisdicional pode ser classificada como diferenciada quando precedida de cognição exauriente e caracterizada apenas pela adequação do procedimento às especificidades da relação material, ou quando dotada de formas típicas de tutela sumária, que busquem empregar efetividade ao processo por meio da limitação da atividade cognitiva. ${ }^{497}$

Assim, as denominadas tutelas diferenciadas são invariavelmente pautadas na limitação da cognição, seja no plano horizontal ou vertical, ou na adaptação do iter procedimental. Nessa mesma linha, para José Roberto dos Santos Bedaque a tutela jurisdicional diferenciada pode ser identificada pela existência de procedimentos específicos, de cognição plena e exauriente, relacionados às especificidades do direito

495 “É fato que o atual Código Civil, a Lei n. 10.406/2002, não se referiu ao assunto e que o Código Civil anterior foi expressamente revogado por ele (art. 2.045). Isso, contudo, não infirma a conclusão de que subsiste, no ordenamento jurídico, o art. 924 do Código de Processo Civil e que a distinção por ele feita entre a 'posse nova' e 'posse velha', emprestando a essa (na perspectiva do autor, importa frisar) um procedimento especial e não àquela, é plenamente válida. Não há, com efeito, nada, na perspectiva constitucional, que possa seriamente ser levado para afastar a cogência daquela regra” (BUENO, Cassio Scarpinella. Curso sistematizado de direito processual civil, v. 2, t. II, p. 69).

${ }^{496}$ BEDAQUE, José Roberto dos Santos. As formas diferenciadas de tutela no processo civil brasileiro. Temas Atuais do Direito Processual Ibero-americano, Relatórios e Conferências das XVI Jornadas Iberoamericanas de Direito Processual, p. 60-123.

${ }^{497}$ PROTO PISANI, Andrea. Appunti sulla giustizia civile, p. 215. 
material, ou "a regulamentação de tutelas sumárias típicas, precedidas de cognição não exauriente, visando a evitar que o tempo possa comprometer o resultado do processo". 498

O primeiro significado - especialidade procedimental - remete-nos imediatamente ao tema já tratado dos procedimentos especiais (item 4.5), dotados de adaptações que levam em conta as peculiaridades das relações materiais. Interessa-nos, entretanto, para a apresentação do tema relativo às liminares das ações possessórias, o segundo sentido atribuído à expressão tutela jurisdicional diferenciada, referente às tutelas denominadas “sumárias” por José Roberto dos Santos Bedaque.

Não faltam, na doutrina, teorias que buscam identificar e categorizar essas tutelas, que têm como característica comum a antecipação, total ou parcial, do provimento jurisdicional ou de seus efeitos.

Teori Albino Zavascki afirma que, paralelamente à tutela definitiva, os sistemas costumam oferecer outra espécie de tutela jurisdicional, qual seja a "tutela diferenciada consistente, em essência, na outorga de providências de dois tipos: (a) providências antecipatórias do gozo do direito vindicado e (b) providências de garantia para a futura execução”, ${ }^{499}$ e assim cria a categoria de tutela provisória, apontando como espécies as medidas cautelares e as antecipatórias.

José Roberto dos Santos Bedaque não distingue tais espécies de tutela de urgência pelo caráter satisfativo, porquanto sustenta que algumas medidas cautelares são dotadas de caráter satisfativo. ${ }^{500}$

Já Luiz Fux indica como espécies de tutelas sumárias a tutela de segurança e a tutela de evidência, sendo aquela primeira subordinada aos requisitos da urgência (periculum in mora) e do fumus boni iuris, e esta última na evidência do direito que

${ }^{498}$ BEDAQUE, José Roberto dos Santos. Tutela cautelar e tutela antecipada: tutelas sumárias e de urgência, p. 25.

${ }^{499}$ ZAVASCKI, Teori Albino. Antecipação da tutela, p. 26-27.

500 “Admissível a tutela cautelar de urgência, de conteúdo antecipatório, para assegurar a eficácia prática da tutela cognitiva-declaratória. Não se antecipa em sede cautelar o efeito declarativo da sentença, mas eventuais efeitos práticos inerentes à declaração da existência ou inexistência do direito” (BEDAQUE, José Roberto dos. Tutela cautelar e tutela antecipada: tutelas sumárias e de urgência, p. 203). 
fundamenta a pretensão do autor, sendo exemplo desta, segundo o autor, a liminar do mandado de segurança, ${ }^{501}$ e também a liminar das ações possessórias de força nova, como adiante será demonstrado.

Na concepção de Cândido Rangel Dinamarco, há uma categoria denominada medidas de urgência, e dentro dela as espécies tutela jurisdicional antecipada e a tutela cautelar. Segundo o autor, são “técnicas teoricamente diferentes, endereçadas a situações diferentes, mas todas têm o comum objetivo de neutralizar os efeitos maléficos do decurso do tempo sobre os direitos”. ${ }^{502}$ E para estabelecer a diferença conceitual entre uma e outra, Dinamarco esclarece que a tutela antecipada oferece ao autor, "desde logo, a fruição integral ou parcial do próprio bem ou situação pela qual litiga”, enquanto a cautelar se destina a "proteger o processo em sua eficácia ou na qualidade de seu produto final”. ${ }^{503}$

Joel Dias Figueira Jr. ${ }^{504}$ afirma que as tutelas de urgência têm como fundamento a “provável exigência do direito que constituirá, ou já constitui, objeto do processo à cognição pela ou limitada, podendo estar ou não acompanhada dos requisitos denominados de fumus boni iuris e periculum in mora”, e que as suas espécies podem ser identificadas a partir de uma classificação ternária: “as cautelares propriamente ditas; as tutelas antecipatórias e as satisfativas autônomas”, e na primeira espécie estariam as cautelares puras ou próprias, na segunda as antecipatórias, específicas ou genéricas e, na terceira, aquelas do tipo sumário injuncional, que se assemelham à ação monitória.

Portanto, em linhas gerais, é possível depreender desses conceitos que a diferenciação da tutela jurisdicional, em relação à sumariedade, se dá pela antecipação dos resultados almejados com o provimento final, isto é, a diferença está na anterioridade da tutela, que se opõe à tutela plena e de cognição exauriente.

Entretanto, nota-se que as classificações doutrinárias apresentadas seguem critérios diversos, pois ora classificam essas tutelas por sua natureza, ora classificam pelos

\footnotetext{
${ }^{501}$ FUX, Luiz. Tutela de segurança e tutela da evidência (fundamentos da tutela antecipada), p. 311.

502 DINAMARCO, Cândido Rangel. Instituições de direito processual civil, v. 1, p. 165.

503 Idem, ibidem, p. 165.

${ }^{504}$ FIGUEIRA JR., Joel Dias. Liminares nas ações possessórias, p. 153-165.
} 
requisitos. Em razão disso, entendemos ser possível propor uma classificação mais abrangente dessas tutelas diferenciadas, com apoio no conceito de "tutela antecipada" apresentado por Cassio Scarpinella Bueno, adiante exposto.

Como ensina o referido autor, pode-se identificar a tutela diferenciada pelo critério distintivo do momento em que ocorre a prestação jurisdicional, e assim teríamos a tutela antecipada e a ulterior. ${ }^{505}$ Segundo Cassio Scarpinella Bueno, é “ulterior” a tutela jurisdicional que se presta somente após a liberação da eficácia decorrente do trânsito em julgado da sentença, e “antecipada”, sob essa perspectiva, “é aquela que se verifica em todos os casos em que a liberação da eficácia (da própria tutela jurisdicional, portanto) antecede, por liberação judicial, o instante procedimental pré-valorado pelo legislador”. ${ }^{506}$

A partir desse conceito, identifica-se como "tutela jurisdicional antecipada" aquela que se opõe à “ulterior”, esta obtida por meio da cognição plena e exauriente; vale dizer, a tutela antecipada, segundo esse conceito abrangente, consiste na decisão que antecipa a satisfação ou a proteção do direito.

Dentro da categoria das “tutelas antecipadas” - e aqui se refere à antecipação lato sensu, e não àquela específica do artigo 273 do Código de Processo Civil ${ }^{507}$-, portanto, as espécies de tutelas que se dividem segundo os critérios da natureza jurídica e dos requisitos.

E assim, no tocante à sua natureza, pode a tutela antecipada ser classificada em tutela antecipada (stricto sensu), ou satisfativa, e em tutela cautelar, ou preservativa, ou seja, o elemento de distinção está na satisfação ou preservação do direito, visto que, por meio da tutela cautelar, alcança-se apenas a salvaguarda do direito, enquanto a antecipação, nos moldes previstos pelo legislador, implica a satisfação total ou parcial.

\footnotetext{
505 BUENO, Cassio Scarpinella. Curso sistematizado de direito processual civil, v. 1, p. 334.

${ }^{506}$ Idem, ibidem, p. 336.

507 A denominação "tutela antecipada” atribuída por Cassio Scarpinella Bueno à categoria ora apresentada não deve ser confundida com a tutela antecipada segundo o conceito do art. 273 do CPC, que, consigo, carrega o caráter de satisfatividade. Esta tutela antecipada (stricto sensu), como será demonstrado, é espécie daquela (lato sensu).
} 
Quanto aos requisitos, é possível classificar a antecipação da tutela em tutela de urgência, que se fundamenta na probabilidade do direito alegado e no risco de perecimento do direito em conflito, e em tutela de evidência, que se apresenta quando, pelo elevado grau de probabilidade do direito alegado, for injusta e desnecessária a espera pelo provimento final, sendo dispensável, portanto, a demonstração do risco de perecimento do direito.

Logo, a antecipação da eficácia da tutela jurisdicional, que será sempre provisória, porquanto não tem aptidão de solucionar o conflito por si só, ${ }^{508}$ pode ser identificada, quanto à sua natureza, pela satisfação do direito ou por sua conservação e, quanto aos requisitos exigidos para sua concessão, pelo risco de perecimento do direito (periculum in mora, receio de dano irreparável etc.) e pelo considerável grau de probabilidade (evidência, fumus boni iuris, verossimilhança etc.), ou apenas por este último requisito.

Dessa forma, levando em consideração ambos os critérios de classificação apresentados, entendemos ser possível, a partir deles, identificar os seguintes grupos de tutelas que são concedidas antes do provimento final para satisfazer direito ou prevenir o seu perecimento: (a) tutela satisfativa de urgência, que visa a satisfazer antecipadamente o direito em razão do risco de dano e da probabilidade do direito, a exemplo da tutela concedida pela regra geral do artigo 273 do Código de Processo Civil - a tutela de urgência será sempre apoiada na probabilidade, visto que não se pode considerar a urgência sem a presença de um grau mínimo de aparência do direito; (b) tutela satisfativa de evidência, na qual também há satisfação do direito em conflito, mas sem a necessidade de demonstração do risco de perecimento de direito, desde que demonstrada a probabilidade do direito alegado, como no caso do direito incontroverso previsto no artigo 273 , § 6. ${ }^{\circ}$, do Código de

${ }^{508}$ É objeto de proposta, pela doutrina brasileira, a estabilização da tutela antecipada, que se aproximam do référé francês e belga, de algumas hipóteses específicas do processo civil italiano e da tutela autossatisfativa da Argentina. Pelo sistema atual, a tutela antecipada não possui aptidão para se estabilizar, pois sua eficácia depende da sentença, esta, sim, passível de imutabilidade. Desta forma, por ser provisória e instrumental, defende-se na doutrina que a tutela antecipada tem características semelhantes àquelas do pronunciamento cautelar, diferenciando-se apenas no tocante à sua satisfatividade, dado que a cautelar tem como objetivo assegurar a utilidade do processo, e não satisfazer direitos. A proposta de estabilização da tutela antecipada consiste em alterar a legislação vigente para tornar definitivo e suficiente o comando da decisão antecipatória de acordo com a vontade das partes, deixando que elas decidam sobre a conveniência de dar ou não prosseguimento à demanda nos moldes tradicionais, com atividades instrutórias, cognição plena e exauriente do juiz e a correspondente sentença de mérito. No entanto, embora a ideia tenha sido aventada no Anteprojeto do Novo Código de Processo Civil, a proposta parece não ter sido acolhida. 
Processo Civil; e (c) tutela conservativa, que assegura o direito em razão urgência decorrente do perigo de seu perecimento e da sua probabilidade, como ocorre na medida cautelar de arresto, por exemplo.

Esclareça-se que a expressão “evidência” deve ser compreendida de forma ampla, como sinônimo de "relevante grau de probabilidade”, que poderá variar de acordo com a situação em análise. Considerando-a com tal abrangência, a expressão “evidência” deverá abarcar tanto a certeza decorrente do fato incontroverso (art. 273, § 6. ${ }^{\circ}$, CPC) como a denominada verossimilhança, exigida para a antecipação de tutela com fundamento na regra geral (art. 273, CPC).

A proposta de classificação ora apresentada não tem como pretenso objetivo o de substituir aquelas clássicas previstas na doutrina, mas simplesmente o de permitir a correta classificação da liminar das ações possessórias, que dependerá do conceito de tutela de evidência. Ou seja, se nominada como "tutela de urgência”509 a categoria dentro da qual se encontram todas as decisões que antecipam o provimento jurisdicional final - satisfazendo ou conservando direito -, seria um erro inserir nessa categoria a tutela de evidência, que tem como característica marcante a dispensa do requisito da urgência.

O que nos importa para a compreensão do sistema da liminar nas ações possessórias é, portanto, a distinção entre tutela cautelar (conservativa) e tutela antecipada (satisfativa), ${ }^{510}$ assim como a distinção entre tutela de urgência e tutela de evidência.

Deve-se compreender a expressão "liminar” de forma abrangente, não podendo ser vista apenas como o provimento judicial proferido no início do processo, referido somente para indicar o momento da sua prolação, mas sim como o provimento que

\footnotetext{
${ }^{509}$ THEODORO JÚNIOR, Humberto. Curso de direito processual civil, v. 2, p. 670.

${ }^{510}$ Pondere-se, todavia, que a distinção entre tutela cautelar e antecipatória, apesar de didaticamente importante, não deve ser levada ao extremo formalismo, a ponto de, na prática, dar ensejo ao indeferimento da concessão de medida de urgência sob o pretexto de formulação equivocada do pedido. E, para que isso não ocorra, o nosso sistema processual já prevê a fungibilidade das liminares (art. 273, § 7. $\left.{ }^{\circ}, \mathrm{CPC}\right)$.
} 
antecipa o julgamento final, e que deve, por isso, ser identificado também por seu conteúdo. $^{511}$

Encontram na doutrina afirmações de que a liminar das possessórias seria medida cautelar com caráter satisfativo, ${ }^{512}$ mas tal posicionamento, a toda evidência, é resquício da época em que ainda não havia em nosso sistema a regra geral da antecipação de tutela prevista no artigo 273 do Código de Processo Civil, em que os juristas se esforçavam para atribuir tal caráter às medidas cautelares com o objetivo de alargar as hipóteses de seu cabimento.

Nesse sentido, Joel Dias Figueira Jr. reconhece a natureza antecipatória da liminar das possessórias ao afirmar que a sua concessão não exige a existência do requisito que a doutrina reputa ser indispensável para as cautelares, ou seja, o periculum in mora, e que “as liminares possessórias têm caráter antecipatório das respectivas sentenças de procedência”. ${ }^{513}$ No mesmo sentido, Nelton dos Santos, ${ }^{514}$ Arruda Alvim, ${ }^{515}$ Adroaldo Furtado Fabrício, ${ }^{516}$ Maurício Giannico, ${ }^{517}$ e Nelson Nery, para quem a liminar possessória “tem caráter de adiantamento do resultado do pedido de proteção possessória”, visto que o

511 “Não há dúvida de que, de um modo geral, quando se fala em liminar está-se referindo a provimento judicial decretado ao início do processo [...] Não é apenas em razão do momento de seu aparecimento que a decisão do juiz é considerada uma 'liminar'. Há liminares proferidas após justificação ou após a citação do demandado e nem por isso, apesar de já ultrapassada a porta de entrada, deixam de ser consideradas liminares [...] a liminar consiste em provimento em provimento que antecipa providência que, pelo regime processual normal, ocorreria apenas como eficácia da futura sentença de procedência" (ZAVASCKI, Teori Albino. Antecipação de tutela, p. 197-198).

512 LACERDA, Galeno. Comentários ao Código de Processo Civil, p. 15.

513 FIGUEIRA JR., Joel Dias. Liminares nas ações possessórias, p. 190.

514 SANTOS, Nelton dos. In: MARCATO, Antônio Carlos (Coord.). Código de Processo Civil interpretado, p. 2417.

515 ARRUDA ALVIM; ASSIS, Araken de; ALVIM, Eduardo Arruda. Comentários ao Código de Processo Civil, p. 1855.

516 “A liminar possessória tem em comum, sim, com a antecipação de tutela agora introduzida no sistema processual brasileiro, e a diferenciá-la da tutela cautelar, a particularidade de referir-se ao próprio mérito da causa, vale dizer, ao mesmo bem da vida cuja atribuição ao autor, em regra, só seria possível como efeito da sentença. Não se trata de garantir a efetividade de um provimento futuro, mas de outorgar ao autor, antes mesmo da sentença, o gozo da posição juridicamente vantajosa que esta, sendo de procedência, lhe atribuiria" (FABRÍCIO, Adroaldo Furtado. Comentários ao Código de Processo Civil, v. 8, t. III, p. 485).

${ }^{517}$ GIANNICO, Maurício; CHIOVITTI, Alexandre Paulichi. Tutela de urgência e tutela de evidência sob a ótica da efetividade. Temas atuais das tutelas diferenciadas, p. 591. 
provimento liminar funcionaria como se o juiz tivesse julgado procedente o pedido “antecipada e provisoriamente, até que seja feita a instrução e sobrevenha a sentença”. 518

Conforme observado por Cândido Rangel Dinamarco, a edição do artigo 273 do Código de Processo Civil possibilitou a percepção de que “as liminares tipificadas em vários tópicos do direito positivo não são outra coisa senão casos específicos de antecipação da tutela jurisdicional”, ${ }^{519}$ e, segundo o autor, a diferença entre elas e a ampla previsão do artigo 273 do Código de Processo Civil está na sua tipicidade, tornando atípicas as antecipações concedidas com fundamento neste dispositivo legal.

Em razão disso é que se nota um tratamento especial da proteção processual da posse, que poderá ser concedida, em sede de liminar, por meio da antecipação da tutela jurisdicional, mesmo sem a demonstração da urgência peculiar ao caso concreto. Seguindo esse mesmo entendimento, Cândido Rangel Dinamarco afirma que "o tradicional zelo ocidental pela posse manda que, presente a boa probabilidade do direito do autor, a liminar seja concedida sem outras investigações”. ${ }^{520}$ No mesmo sentido, José Roberto dos Santos Bedaque sustenta que a liminar possessória representa tutela de evidência, na medida em que depende apenas da plausividade do direito. ${ }^{521}$

Nota-se, portanto, que a expressão "tutela de evidência”, inaugurada pelo processualista Luiz Fux para indicar a tutela provisória deferida com fundamento tão

518 NERY JUNIOR, Nelson; NERY, Rosa Maria de Andrade. Código de Processo Civil comentado, p. 1398.

519 DINAMARCO, Cândido Rangel. Fundamentos do processo civil moderno, v. 2, p. 1532.

520 “Uma outra diferença entre as antecipações típicas próprias à proteção possessória e aquelas inerentes ao poder geral antecipatório disciplinado pelo art. 273 do Código de Processo Civil consiste em que (a) para as últimas é indispensável o periculum in mora ou alguma outra situação descrita em tal artigo, enquanto (b) para os interditos possessórios esse requisito não é exigido. Exige-se o fumus boni iuris, que o juiz encontrará já nos documentos iniciais ou mediante a justificação que a lei o autoriza a fazer (arts. 928929), mas o tradicional zelo ocidental pela posse manda que, presente a boa probabilidade do direito do autor, a liminar seja concedida sem outras investigações” (DINAMARCO, Cândido Rangel. Fundamentos do processo civil moderno, v. 2, p. 1532).

521 "Lícito concluir, portanto, justamente com o renomado processualista pátrio, que a tutela diferenciada funda-se ora na urgência na entrega da prestação jurisdicional, ora na evidência de que o direito afirmado existe. Teríamos, pois, como espécies de tutela diferenciada, a tutela de urgência e a de evidência. [...] a tutela diferenciada, portanto, pode estar vinculada ao valor urgência, ao valor evidência ou a ambos. Na antecipação de prova, por exemplo, leva-se em conta apenas a urgência; a liminar possessória e a antecipação baseada no abuso do direito de defesa já dependem apenas da plausividade do direito, ou seja, da evidência; o sequestro, por fim, só pode ser concedido se presentes o risco e a plausividade, ou seja, a urgência e a evidência” (BEDAQUE, José Roberto dos. Tutela cautelar e tutela antecipada: tutelas sumárias e de urgência, p. 364). 
somente na evidência do direito reclamado pelo demandante, necessária para evitar que a demora natural do processo impeça a satisfação de um direito sobre o qual há grande probabilidade, $^{522}$ aplica-se perfeitamente à liminar possessória.

Isso porque, pelo que se denota das normas dos artigos 924 e 928 do Código de Processo Civil, a tutela jurisdicional pretendida por meio das ações possessórias, qual seja a proteção da posse contra esbulho, turbação e ameaça, será antecipadamente concedida, caso estejam comprovados os requisitos exigidos pelo legislador. Logo, não há falar em natureza cautelar da liminar do procedimento especial dos interditos possessórios, porquanto é dotada de caráter satisfativo, e não somente preventivo, o que nos permite classificá-la como tutela antecipada satisfativa de evidência.

Assim, para a tutela jurisdicional da posse contra a "força nova", o ordenamento jurídico brasileiro regulamentou um procedimento especial e o enriqueceu com o que hodiernamente se denomina tutela de evidência, visto que as liminares das possessórias não dependem da presença do requisito da urgência (periculum in mora ou "risco de dano irreparável ou de difícil reparação”), mas apenas da demonstração fática da violação ao direito do autor, da moléstia à posse.

Teori Albino Zavascki sustenta que, nas relações possessórias, a urgência é presumida pelo legislador, "porque tende a ocorrer nas situações fáticas descritas na norma”. ${ }^{523}$ Entendemos correto, no entanto, considerar que se trata de relevância do direito, considerada pelo legislador para a atribuição de um tratamento processual especial. Não há, pois, presunção legal da urgência, mas simplesmente previsão de um procedimento especial para uma relação jurídica determinada, por razões de conveniência política que não admite questionamentos. ${ }^{524}$

522 “[...] a tutela de evidência, ora proposta, é mais ampla e alcança todos os níveis de satisfatividade, processos e procedimentos, tendo como finalidade estender a tutela antecipatória a todos os direitos evidentes, pela inegável desnecessidade de aguardar-se o desenrolar de um itinerário custoso e ritualizado em busca de algo que se evidencia no limiar da causa posta em juízo" (FUX, Luiz. Tutela de segurança e tutela da evidência, p. 318).

${ }^{523}$ ZAVASCKI, Teori Albino. Antecipação da tutela, p. 30.

524 "São, portanto, razões de conveniência política que traçam a especialidade de determinados procedimentos para o exercício da função jurisdicional à luz de determinadas situações de direito material conflituoso e outras não [...] Desde que estes procedimentos observem o 'modelo constitucional do 
Portanto, pela interpretação conjunta dos artigos 924, 927 e 928 do Código de Processo Civil, conclui-se que a liminar deverá ser deferida, independentemente da demonstração de efetiva urgência no caso concreto, se preenchidos os requisitos que se relacionam à existência do direito alegado. Não se exige, para tanto, a certeza que só é alcançada com a cognição exauriente, assim como não seria suficiente o fumus boni iuris; deve-se buscar um grau intermediário de probabilidade do direito, semelhante ao que se exige na regra geral da tutela antecipada (art. 273, CPC), que seja suficiente para autorizar a satisfação antecipada do direito. ${ }^{525}$

Dessa forma, não precisa o autor demonstrar que, se não deferida a liminar e aguardada a sentença, seu direito perecerá, ou que sofrerá danos irreparáveis ou de difícil reparação; basta que comprove a sua posse, a turbação ou esbulho, a sua data e a permanência da moléstia. Entretanto, sabe-se que maior ênfase se dá, no momento inicial do processo, para fins de concessão da liminar nas ações possessórias, à demonstração da posse violada e à data da turbação ou esbulho, o que permitirá caracterizar a "força nova" indispensável para alcançar a liminar de proteção provisória da posse. ${ }^{526}$

Logo, tem-se que, para a proteção possessória contra “força nova”, o ordenamento jurídico brasileiro prevê um procedimento especial dotado de um mecanismo que autoriza, de modo peculiar, a antecipação da tutela jurisdicional, com satisfação do direito

processo civil' - especificamente os traços peculiares e inafastáveis de qualquer processo como método de manifestação do Estado-juiz -, não há espaço para qualquer discussão a respeito da escolha feita pelo legislador” (BUENO, Cassio Scarpinella. Curso Sistematizado de Direito Processual Civil, v. 1, p. 514).

525 “No campo das medidas cautelares, tomam-se providências conservativas, apenas, dos elementos do processo, assegurando, dessa forma, a futura execução do que a sentença de mérito venha a determinar. Já no âmbito da tutela antecipatória entram medidas que permitem a imediata satisfação da pretensão (direito material) da parte, embora em caráter provisório e revogável. Para valer-se da tutela cautelar, basta ao litigante demonstrar uma aparência de direito (fumus boni iuris) e o receio fundado de um dano iminente e de difícil reparação (periculum in mora). Mas, para alcançar a satisfação antecipada do direito material, a lei exige da parte a prova inequívoca tendente a um imediato juízo de verossimilhança, além do perigo de dano iminente (CPC, art. 273, I), ou, alternativamente, o abuso de direito de defesa por parte do réu (art. 273, II), ou, ainda, a ocorrência de parte dos pedidos cumulados apresentar-se incontroversa (art. 273, § 6. ${ }^{\circ}$ )" (THEODORO JÚNIOR, Humberto. Tutelas diferenciadas como meio de incrementar a efetividade da prestação jurisdicional, p. 18).

${ }^{526}$ Nesse sentido: "Dentre os requisitos postos nos incisos I a IV, dois se apresentam como especialmente exigentes: a posse, que é pressuposto fundamental e comum a todas as formas de tutela possessória, e a data da turbação ou esbulho, decisiva no caracterizar ou não a 'força nova', sem a qual fica de pronto afastada a possibilidade de proteção provisional da posse, ainda que provada esta” (FABRÍCIO, Adroaldo Furtado. Comentários ao Código de Processo Civil, v. 8, t. III, p. 485). 
reclamado, sem exigência do requisito da urgência, dispensando o autor de demonstrar que a espera pela sentença poderá prejudicá-lo de forma irreparável.

Daí afirmar que a proteção processual da posse goza de certo privilégio em relação à tutela jurisdicional da propriedade, pois, por meio da ação reivindicatória, que se processa pelo rito ordinário e tem por objeto a restituição de coisa com fundamento no domínio, a liminar somente poderá ser obtida pela regra geral do artigo 273 do Código de Processo Civil, que exige, como se sabe, a demonstração da verossimilhança e do risco de dano irreparável ou de difícil reparação, ou seja, será indispensável a verificação da urgência no caso concreto.

Por isso, embora tenham a mesma natureza as liminares concedidas com supedâneo na regra geral da antecipação de tutela (art. 273, CPC) e aquelas fundamentadas no procedimento especial das ações possessórias - natureza antecipatória satisfativa -, seus requisitos são diversos e não devem ser confundidos, porquanto, repita-se, não se exige para a tutela interdital contra "força nova” a presença do requisito específico da urgência. $^{527}$

Desse modo, não há dúvida de que o procedimento especial das ações possessórias privilegia a proteção da posse de menos de ano e dia com a possibilidade de concessão de liminar sem o requisito da urgência. Pode-se perguntar, então, qual seria a razão desse privilégio. E para responder a essa indagação poder-se-ia cogitar de inúmeros motivos.

${ }^{527}$ Nesse sentido: “As liminares possessórias não se encartam na categoria liminares 'acautelatórias', senão que parecem encontra justificativa na concepção teleológica da proteção possessória, que é a de conservar (ou restabelecer) uma situação de fato. Em casos tais, a urgência não é cogitada como requisito necessário à concessão da liminar. Quer dizer: a urgência não embasa a liminar e a proteção possessória nada tem a ver com um possível perecimento de um direito. A liminar possessória tem caráter antecipatório. Deve ser concedida se tratar-se de ação de força nova (arts. 924 e 928), não sendo exigível, nesse caso, diferentemente da hipótese do art. 273, I, a presença do requisito urgência” (ARRUDA ALVIM; ASSIS, Araken de; ALVIM, Eduardo Arruda. Comentários ao Código de Processo Civil, p. 1855). "Cumpre observar, de início, que as medidas antecipatórias específicas contempladas pelo art. 928 do Código de Processo Civil (tutela de evidência) não coincidem plenamente, em seus objetivos e pressupostos, com aquela prevista, em caráter geral, no art. 273 do mesmo diploma legal, enquanto esta torna possível ao autor usufruir praticamente da situação de titular de direito ainda não reconhecido definitivamente, a finalidade daquelas é exclusivamente a de propiciar a rápida obtenção do resultado prático do processo, sem qualquer ligação com o perigo de dano concreto à satisfação do direito" (MARCATO, Antônio Carlos. Procedimentos especiais, p. 149). 
O primeiro deles seria a necessidade de facilitação da defesa da propriedade, segundo a concepção de Ihering. Entretanto, não seria satisfatório, porquanto, na atualidade, em muitas situações seria mais fácil demonstrar o direito de propriedade por meio da escritura de compra e venda registrada na matrícula do imóvel do que comprovar a posse por meio de testemunhas.

Seria possível cogitar a resposta na importância da proteção da posse para assegurar a paz social, mas tal explicação também não seria suficiente, eis que a defesa da propriedade é tão ou mais importante para esse fim.

Excluídos os motivos antes levantados, parece-nos que a justificativa para a permanência desse privilégio em nosso sistema está, em verdade, na força da tradição. A proteção da posse sempre foi outorgada dessa forma, com rapidez e em juízo de cognição sumária, desde o direito romano até os primórdios do direito português e, por consequência, em toda a história do direito brasileiro, e essa solução é sinônimo de garantia ao jurisdicionado, visto que a objetividade dos requisitos exigidos pela lei evita que a concessão da liminar dependa da definição de um conceito vago - a urgência - pelo juiz, como ocorre na regra geral da tutela antecipada (art. 273, CPC).

Além disso, a segurança gerada por essa especial proteção processual dispensada à posse certamente reforça a paz social e serve de desestímulo para a prática de atos de turbação e esbulho, pois, se não houvesse esse tratamento especial e imediato, a morosidade do Judiciário poderia ser um incentivo para a ofensa à posse, por assegurar a permanência indevida do ofensor na posse do bem por um período de tempo considerável.

Vale dizer, a proteção da posse por meio de liminar sem a necessidade de demonstração da urgência garante segurança ao possuidor e aos proprietários-possuidores, que dispõem da certeza de que seu direito será sumariamente protegido desde que comprovadas a sua posse e a violação datada de menos de ano e dia.

Nenhum outro requisito, além daqueles previstos no artigo 927 do Código de Processo Civil, impõe-se para a concessão da liminar do procedimento especial das ações possessórias, nem mesmo a prestação de caução pelo autor. É oportuna tal ressalva porque 
a afoita interpretação do artigo 925 do Código de Processo Civil pode gerar a conclusão equivocada de que seria exigível a prestação de caução para a concessão de liminar.

No entanto, o referido dispositivo apenas faculta ao réu provar a inidoneidade do autor beneficiado pela liminar de manutenção ou de reintegração com o objetivo de lhe impor o ônus de prestar caução, sob pena de ser depositada a coisa litigiosa. ${ }^{528}$

A caução tratada no referido dispositivo tem como objetivo garantir possíveis prejuízos decorrentes da liminar, e por isso não deve ser cumprido apenas o ônus atribuído ao autor, de prestar caução sempre que não dispuser de idoneidade financeira, mas também do réu, que “deverá comprovar cumpridamente também a provável ocorrência de perdas e danos efetivos, caso a ação finalmente seja julgada em desfavor do autor”. 529

Todavia, note-se que, se não prestada a caução determinada pelo juízo, não será o caso de revogação da liminar, mas sim de tomar a coisa litigiosa em depósito, o que, diferente da cassação do provimento de urgência, que representaria retorno à situação de ofensa à posse combatida, colocará à salvo a coisa, que em via de regra será entregue a um depositário estranho à lide.

Ainda que feita tal constatação, a exigência de caução com fundamento no referido dispositivo legal pode representar, para alguns autores, ${ }^{530}$ inconstitucionalidade, na medida em que limita o acesso à Justiça àqueles que não têm condições patrimoniais para

\footnotetext{
${ }^{528}$ Segundo Adroaldo Furtado Fabrício, “em se tratando de imóvel, como é mais frequente, é possível que o exercício do encargo de depositário envolva providências de administração do bem, e a isso terá de atender o juiz quando da nomeação” (Comentários ao Código de Processo Civil, v. 8, t. III, p. 477).

${ }^{529}$ FADEL, Sergio Sahione. Código de Processo Civil comentado, v. 2, p. 1141.

530 “A inconstitucionalidade do art. 925 do CPC reside basicamente em dois pontos: a) na limitação do pleno acesso à Justiça, ou ainda melhor, nos dizeres de Kazuo Watanabe, à ordem jurídica justa, tendo em vista que a permanência do efeito antecipatório da tutela definitiva, obtidos sumariamente pelo possuidor turbado ou esbulhado, fica condicionado ao oferecimento de garantia real ou fidejussória, sob pena de supressão da medida e depósito do bem litigioso, configurando esbulho judicial; b) como consequência do motivo anterior, no obstáculo criado pela discriminação entre litigantes pobres e abastados, ferindo o princípio da igualdade” (FIGUEIRA JR., Joel Dias. Liminares nas ações possessórias, p. 372).
} 
oferecer a garantia exigida, posicionamento que adotamos, e que se coaduna com a jurisprudência. $^{531}$

\subsubsection{Liminar quanto a posse de “força velha” (procedimento ordinário)}

Sabe-se, por outro lado, que, com o advento da tutela antecipada, regrada pelo artigo 273 do Código de Processo Civil, nada impede que a liminar seja concedida no procedimento comum, quando a violação da posse contar com mais de ano e dia, desde que presentes os requisitos exigidos no referido dispositivo legal.

Ou seja, considerando a natureza antecipatória satisfativa da decisão que concede a proteção possessória em sede de liminar, é possível que, no procedimento ordinário, para a defesa da posse contra "força velha”, seja igualmente deferida a medida, mas, para tanto, será exigida a demonstração do risco de perecimento do direito, requisito que, como se viu, não se impõe no procedimento especial das ações possessórias. ${ }^{532}$

Assim, se decorrido ano e dia da ofensa à sua posse, ${ }^{53}$ o autor poderá pedir a concessão de liminar, mas com fundamento no artigo 273 do Código de Processo Civil,

531 “Possessória. Manutenção de posse. Liminar. Caução. A regra do artigo 925 do CPC não pode ser interpretada formalmente, de modo a constituir ofensa ao princípio da igualdade jurídica e causar ao autor prejuízo maior do que a turbação que procura evitar. Agravo de instrumento a que se nega provimento” (TJRS, Agravo de Instrumento 183000041, 3. ${ }^{a}$ Câmara Cível, Rel. Ruy Rosado de Aguiar Júnior, j. 09.02.1983).

532 Nesse sentido já se posicionou o Superior Tribunal de Justiça: “[...] É possível a antecipação de tutela em ação de reintegração de posse em que o esbulho data de mais de ano e dia (posse velha), submetida ao rito comum, desde que presentes os requisitos que autorizam a sua concessão, previstos no art. 273 do CPC, a serem aferidos pelas instâncias de origem. 5. Recurso especial provido” (REsp 1139625 RJ, Rel. Min. Maria Isabel Gallotti, 4. ${ }^{\text {a }}$ Turma, j. 12.06.2012, publ. 01.08.2012).

533 É importante ressaltar que o prazo de ano e dia não corre enquanto perdurar o vício da clandestinidade, e igualmente não corre enquanto o possuidor está resistindo por força própria à ofensa. O referido prazo deve ser contado com a exclusão do primeiro dia da ofensa; caso se trate de lesão continuada permanente, deve-se contar a partir do seu início. Nesse sentido: A data a ser considerada como sendo a da turbação ou esbulho - dies a quo do prazo - só pode ser aquela em que se consuma e concretiza a ofensa à posse; enquanto o possuidor está resistindo por seus próprios meios e levando de vencida o ofensor [...] ainda não se consumou a situação fática considerada. Só a partir de quando ocorre a efetiva perda da posse (no esbulho) ou a limitação ao seu livre exercício (na turbação) [...] o prazo começa a fluir. [...] Mesmo abstraída a hipótese de ausência, o princípio é ainda o mesmo se o esbulho ou turbação se faz clandestinamente: o prazo não corre enquanto o ato não chega ao conhecimento do possuidor, ou enquanto não cessa o impedimento em que se achava de atuar contra ele” (FABRÍCIO, Adroaldo Furtado. Comentários ao Código de Processo Civil, v. 8, t. III, p. 167-168). No mesmo sentido: “O prazo se inicia com a efetiva turbação ou o efetivo esbulho praticado contra a posse. O prazo começa a correr a partir da ciência da ocorrência da turbação ou do esbulho, se o ato de violação da posse for clandestino” (NERY 
atentando-se para a exigência do requisito da urgência. Nesse sentido, Arruda Alvim sustenta que, apesar de não ser cabível a liminar prevista no artigo 928 do Código de Processo Civil para proteção da posse às hipóteses de “força velha”, se "presentes os requisitos do art. 273, poderá ser concedida antecipação de tutela, pois não há qualquer incompatibilidade entre o instituto da antecipação de tutela e a disciplina específica das ações possessórias”. 534

Em sentido contrário, Clito Fornaciari Junior sustenta não ser possível a concessão de tutela antecipada no caso de posse velha, pois, segundo seu entendimento, o exercício da posse por esse período confere “à parte contrária uma proteção possessória a que tem direito, de vez que a posse é fato que se altera, quando passados ano e dia, impondo merecer respeito e proteção jurídica a situação tranquilizada". 535 Não concordamos com a opinião do autor, pois essa violação do direito de posse não pode ser protegida somente pelo decurso do prazo de ano e dia, o que somente poderia ocorrer com a presença dos requisitos da usucapião. Ou seja, se é possível conceder a tutela jurisdicional para a proteção da posse contra a força velha, é possível, também, concedê-la antecipadamente, se preenchidos os requisitos da lei.

É evidente, entretanto, que a concessão de liminar para proteção da posse contra “força velha”, com fundamento na regra geral da antecipação de tutela, será naturalmente medida excepcional, porque, se o possuidor demorou mais de ano e dia para buscar a proteção possessória, dificilmente conseguirá demonstrar a urgência para obter uma liminar de reintegração ou manutenção depois desse período.

Portanto, em tese será plenamente possível a concessão da tutela antecipada em ação possessória “de força velha”, eis que não há qualquer incompatibilidade no sistema,

JUNIOR, Nelson; NERY, Rosa Maria de Andrade. Código de Processo Civil comentado, p. 1397). Sobre a contagem em si, esclarece Vicente Greco Filho: "O prazo de ano e dia conta-se da seguinte maneira: o primeiro dia (dia da violação ou turbação) não se conta; no caso de lesão continuada permanente, conta-se do início da lesão; se a lesão é repetida, conta-se do último ato; não se conta no período em que o possuidor retomou a posse plenamente; neste último caso, nova violação desencadeia novo prazo" (GRECO FILHO, Vicente. Direito processual civil brasileiro, v. 3, p. 273).

${ }^{534}$ ARRUDA ALVIM; ASSIS, Araken de; ALVIM, Eduardo Arruda. Comentários ao Código de Processo Civil, p. 1849.

${ }^{535}$ FORNACIARI JÚNIOR, Clito. Da tutela antecipada nas possessórias fundadas na posse velha. Estudos de direito processual civil, p. 251. 
mas é evidente, contudo, que será extremamente difícil, na prática, demonstrar a urgência que torne necessária a prolação de um provimento sumário nessa situação. ${ }^{536}$ Deverão ser analisadas as circunstâncias do caso concreto para que, nas ações possessórias fundadas em ofensa ocorrida há mais de ano e dia, seja possível a aplicação da regra geral do artigo 273 do Código de Processo Civil, sendo necessária, portanto, a análise acurada do caso concreto pelo magistrado, conforme afirmado por Athos Gusmão Carneiro. ${ }^{537}$

Compartilhando desse entendimento, Joel Dias Figueira Jr. admite que, em tese, é viável juridicamente a concessão de liminar pela regra do artigo 273 do Código de Processo Civil em ação possessória ajuizada pelo rito ordinário, além do prazo de ano e dia. No entanto, o mencionado doutrinador sustenta que, se o possuidor não teve urgência para reclamar seu direito dentro do prazo de ano e dia, não teria sequer interesse para requerer tal providência após o decurso do referido prazo "por intermédio de vias transversas, utilizando-se do contido no inc. I do art. 273, que tem por base o perigo de dano a ser rechaçado". 538

Em verdade, o autor admite, mas com extrema repulsa, a viabilidade, ainda que em tese, da aplicação da regra geral da tutela antecipada às ações possessórias de "força velha”, pois sustenta que não seria cabível essa regra genérica para a hipótese em que o legislador previu "normativa de procedimentalidade especial”. 539

Concordamos com o entendimento de que naturalmente será excepcional a concessão de liminar possessória com fundamento no artigo 273 do Código de Processo Civil, porquanto, como manifestado na doutrina referenciada, seria difícil demonstrar a urgência depois de ano e dia da violação da posse. Contudo, discorda-se de que seria

\footnotetext{
${ }^{536}$ NERY JUNIOR, Nelson; NERY, Rosa Maria de Andrade. Código de Processo Civil comentado, p. 1398.

${ }^{537}$ CARNEIRO, Athos Gusmão. Da antecipação de tutela, p. 114.

${ }^{538}$ FIGUEIRA JR., Joel Dias. Liminares nas ações possessórias, p. 206.

539 “[...] aplica-se tão somente a proteção sumária e genérica do art. 273 quando o sistema não prevê uma forma específica de procedimento suficientemente hábil à consecução da antecipação da tutela satisfativa. Havendo previsão normativa de procedimentalidade especial - como se verifica no caso das possessórias -, é juridicamente impossível a obtenção do mesmo tipo de proteção por intermédio da incidência do art. 273, I, quando os mecanismos apropriados deixaram de ser utilizados em tempo oportuno, dando azo à preclusão, que importa, in casu, em decadência à obtenção da tutela urgente” (FIGUEIRA JR., Joel Dias. Liminares nas ações possessórias, p. 207).
} 
inaplicável a regra geral da tutela antecipada para as ações possessórias de “força velha”, uma vez que não há qualquer incompatibilidade no sistema que impeça tal providência.

Ainda sobre esse tema, Leandro Antonio Pamplona faz interessante observação de que a concessão de liminar nas ações possessórias de “força velha”, com fundamento no artigo 273 do Código de Processo Civil, deve atender ao princípio da quieta non movere, ou seja, a inércia do possuidor durante o prazo de ano e dia permitiu que se aquietasse a situação de fato do ofensor, de modo que se mostra conveniente, ao menos em regra, não alterar essa situação em sede de cognição sumária. ${ }^{540}$

Em qualquer dos casos - regra geral da antecipação de tutela ou procedimento especial das ações possessórias -, a liminar somente deve ser deferida se requerida pela parte autora. ${ }^{541}$

\subsubsection{Momento de concessão da liminar nas ações possessórias de "força nova"}

Em relação ao momento de concessão da liminar contra “força nova”, estatui o artigo 928 do Código de Processo Civil as seguintes hipóteses: (a) preenchidos já na inicial os requisitos dispostos no artigo 927 do Código de Processo Civil, o juiz deverá deferir a liminar "sem ouvir o réu” (inaudita altera parte), ou seja, antes de oportunizar o contraditório e antes mesmo de citar o demandado (art. 928, caput, primeira parte); (b) não sendo suficientes as provas da inicial, deverá o juiz designar audiência de justificação prévia, devendo o réu ser citado e intimado para nela comparecer, oportunidade em que, acolhendo a justificação do autor, o juiz logo deferirá a liminar (art. 928, caput, segunda

\footnotetext{
540 “O princípio da quieta non movere, literalmente, consiste em não perturbar o que está tranquilo. Esse princípio romano de manter a situação como está, influenciou o legislador pátrio que privilegiou a situação fática da posse, conforme o art. 1.211 do CC/2002. [...] Passado o ano e dia a posse passa a ser 'velha' não cabendo mais a liminar do procedimento específico. O tempo que caracteriza a posse velha configura a inércia do interessado e, por consequência, vai ao encontro ao princípio da quieta non movere. [...] Se a ação é proposta dentro de um ano e dia fica evidente a urgência na modificação fática. Distribuída após um ano e dia, ou seja, de forma tardia, a demora na busca da modificação fática configura a ausência de urgência, bem como a presunção da boa-fé do possuidor. Por esse motivo, a antecipação de tutela, ainda que possível para os casos de posse velha, deve ser tratada como forma excepcional na prática forense, principalmente em respeito ao princípio da quieta non movere" (PAMPLONA, Leandro Antonio. Antecipação de tutela nas ações possessórias e o princípio quieta non movere. Revista de Processo, ano 37, 205, p. 103/111, mar. 2012).

${ }^{541}$ ARRUDA ALVIM; ASSIS, Araken de; ALVIM, Eduardo Arruda. Comentários ao Código de Processo Civil, p. 1856.
} 
parte); (c) sendo ré no processo pessoa jurídica de direito público, a liminar somente poderá ser deferida após a audiência dos seus respectivos representantes judiciais (art. 928, parágrafo único).

Portanto, na primeira hipótese, tem-se que, estando devidamente comprovado na inicial o direito do autor, representado pelos requisitos do artigo 927 do Código de Processo Civil, ou seja, demonstrados tais requisitos pelos documentos apresentados com a inicial, a liminar deverá ser concedida imediatamente, antes da oitiva do réu.

O juiz deve estar atento à prova desses requisitos, mas é preciso observar que, em face da objetividade que lhes é peculiar, não cabe ao julgador analisar se há ou não necessidade da medida, em razão de urgência ou de qualquer outro fator que considere relevante, nas ações possessórias que seguem o procedimento especial, visto que tal requisito não foi imposto pelo legislador. Se estiverem presentes os requisitos já mencionados, e dispostos no artigo 927 do Código de Processo Civil, deverá - e não "poderá” - o juiz conceder a medida liminar, sob pena de contrariar a disposição expressa da lei; a discricionariedade está na análise da prova dos requisitos, mas, não havendo dúvidas quanto à demonstração destes, deverá o juiz deferir a liminar.

A corroborar tal entendimento, Sergio Sahione Fadel afirma que "não há arbítrio nem discrição do juiz para dar ou negar a medida liminar”, e sim "dever jurisdicional de antecipar ou negar a concessão do interdito possessório reclamado, conforme seja feita ou não a prova prévia dos pressupostos legais”; e conclui o autor que o deferimento da liminar é matéria de apreciação objetiva, e não "medida de favor, nem de conveniência e oportunidade subjetivas do magistrado". ${ }^{542}$ No mesmo sentido assevera Antonio Carlos Marcato que, "presentes os requisitos legais expostos nos arts. 926 e 927 do Código de Processo Civil, deve o juiz conceder a antecipação". 543

Entretanto, encontra-se na jurisprudência certa resistência ao limite do poder discricionário do juiz nessa hipótese, e por isso são comuns as decisões que fundamentam o indeferimento da liminar na suposta falta de prova dos requisitos, quando, na realidade,

\footnotetext{
${ }^{542}$ FADEL, Sergio Sahione. Código de Processo Civil comentado, v. 2, p. 1144.

${ }^{543}$ MARCATO, Antônio Carlos. Procedimentos especiais, p. 149.
} 
estão todos comprovados. Tal fundamento, que abre o campo para o subjetivismo, representa, muitas vezes, a resistência do juiz em deferir a liminar nas ações possessórias de “força nova”, mesmo quando preenchidos os requisitos do procedimento especial, por considerar inexistente a urgência que, todavia, é dispensada pelo legislador. ${ }^{544}$

Aliás, sobre a discricionariedade na esfera judicial é de grande valia a pontuação feita por Teresa Arruda Alvim Wambier, que a diferencia da discricionariedade que, na esfera administrativa, oportuniza a escolha de mais de um caminho, visto que o juiz não tem essa liberdade de escolha de caminhos, cabendo-lhe tão somente o preenchimento dos conceitos vagos por meio da atividade interpretativa, e a subsunção do fato à norma. ${ }^{545}$

Não se olvida, porém, que é de extrema dificuldade a comprovação da situação da posse e da sua violação por meio das provas documentais que instruem a inicial. Por certo que os documentos que geralmente são apresentados pelos autores das ações possessórias com a inicial, como o título de domínio, declarações de terceiros, boletins de ocorrência, são, em determinados casos, insuficientes para a comprovação dos requisitos do artigo 927 do Código de Processo Civil. E por isso é que o juiz, constatando que não há provas suficientes na inicial a autorizar a concessão da liminar, deverá ${ }^{546}$ designar audiência de justificação prévia, determinando a citação do réu para que nela compareça.

Destina-se a referida audiência, portanto, a viabilizar a comprovação dos fatos necessários à concessão da liminar de proteção possessória no procedimento especial,

544 “Costuma-se encontrar em alguns acórdãos a afirmativa de que o juiz teria grande autonomia ou poder discricionário para solucionar o pedido de mandado liminar nas ações possessórias. A tese, porém, não merece guarida. A lei confere ao possuidor o direito à proteção liminar de sua posse, mas o faz subordinando-o a fatos precisos, como a existência da posse, a moléstia sofrida na posse e a data em que tal tenha ocorrido. Logo, reunidos os pressupostos da medida, não fica ao alvedrio do juiz deferi-la ou não, o mesmo ocorrendo quando não haja a necessária comprovação" (THEODORO JÚNIOR, Humberto. Curso de direito processual civil, v. 3, p. 121).

${ }^{545}$ WAMBIER, Tereza Celina de Arruda Alvim. Os agravos no CPC brasileiro, p. 245.

546 “Possessória. Reintegração de posse. Alegação de esbulho possessório. Liminar. Indeferimento sem designação de audiência de justificação. Necessidade de sua realização. Inteligência do artigo 928, segunda parte, do Código de Processo Civil. Desconstituição da decisão, de ofício, com determinação para designação de audiência. Prejudicado o recurso" (TJSP, Agravo de instrumento 0121585-

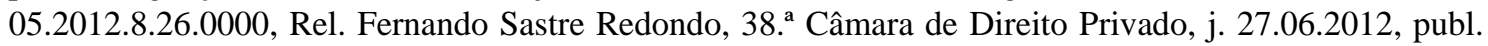
28.06.2012). 
permitindo-se a oitiva de "testemunhas ou dos interessados, inclusive com o depoimento de autor e réu”. 547

Antonio Carlos Marcato sustenta que “ao réu não é deferido o direito de produzir prova testemunhal nessa audiência”, pois a justificação é incumbência atribuída ao autor, que poderá, por meio dela, convencer o juiz quanto à presença dos requisitos que autorizam a concessão de liminar. Ressalva o autor, ainda, que não se trata de audiência de instrução e julgamento, e que "a realidade do dia a dia forense demonstra que a oitiva de testemunhas do réu pode muitas vezes atuar como causa geradora de incidentes inúteis ou protelatórios”. 548

No mesmo sentido, Joel Dias Figueira Jr. defende que “ao réu não é permitido fazer justificação paralela à do autor, produzindo prova testemunhal ou formulando novas perguntas com o escopo de produzir a contraprova”. 549

No entanto, muito embora a audiência de justificação prevista no procedimento especial das ações possessórias tenha realmente como objetivo fortalecer as provas trazidas pelo autor em sua inicial no tocante aos requisitos exigidos para a concessão da liminar de proteção possessória, entendemos que não se justifica a vedação à produção de provas pelo réu nessa oportunidade, não apenas porque as testemunhas trazidas pelo réu podem comprovar a inverdade das alegações do autor, ${ }^{550}$ mas também em atenção à possibilidade

${ }^{547}$ FADEL, Sergio Sahione. Código de Processo Civil comentado, v. 2, p. 1145.

548 “E ao réu não é deferido o direito de produzir prova testemunhal nessa audiência, pelas razões a seguir enunciadas: primeira: a justificação é incumbência atribuída unicamente ao autor, que se valerá da respectiva audiência, portanto, única e exclusivamente para convencer o juiz de que preenche os requisitos exigidos para a concessão de liminar - facultado ao réu presente o direito de reinquirir as testemunhas do autor; segunda: não se cuida de audiência de instrução e julgamento, mas de ato processual destinado a permitir, ao requerente da liminar, a possibilidade de comprovar por meio de testemunhas o que não pôde demonstrar documentalmente; terceira: a realidade do dia a dia forense demonstra que a oitiva de testemunha do réu pode muitas vezes atuar como causa geradora de incidentes inúteis ou protelatórios, mormente quando se busca a demonstração de fatos absolutamente estranhos à pretensão a ser examinada imediatamente (que é, tão só, a de concessão de liminar), enveredando as partes, nessa fase inicial do processo, para a discussão de questões pertinentes exclusivamente ao mérito do pedido possessório, sem que até então sequer tenha chegado o momento de oferta de resposta pelo réu” (MARCATO, Antônio Carlos. Procedimentos especiais, p. 150).

549 FIGUEIRA JR., Joel Dias. Liminares nas ações possessórias, p. 325.

550 “Poderá o réu, ainda, produzir prova tendente ao indeferimento do pedido de liminar” (SANTOS, Nelton dos. In: MARCATO, Antônio Carlos (Coord.). Código de Processo Civil interpretado, p. 2417). 
de demanda do réu na contestação (art. 922, CPC), com a formulação do pedido de proteção da posse (item 4.9.1).

Nesse sentido segue a orientação jurisprudencial, com supedâneo na garantia do contraditório que, obviamente, não deve ser negada ao demandado na audiência de justificação, ${ }^{551}$ ainda que se assuma o risco de permitir eventual conduta protelatória do réu.

Quanto à norma prevista no parágrafo único do artigo 928 do Código de Processo Civil, de que não poderá ser deferida a manutenção ou a reintegração liminar sem a prévia audiência dos respectivos representantes judiciais, muito se discute na doutrina e na jurisprudência sobre a sua constitucionalidade. ${ }^{552}$ Encontra-se previsão idêntica em relação à liminar do mandado de segurança coletivo (art. 2. ${ }^{\circ}$, Lei 8.437/1992), em que a liminar somente poderá ser concedida após a audiência do representante judicial da pessoa jurídica de direito público.

A inconstitucionalidade estaria no estabelecimento de oportunidades processuais desiguais em privilégio de pessoa jurídica de direito público, por violação ao princípio da isonomia. ${ }^{553}$ Entretanto, o questionamento sobre a constitucionalidade perde força pela constatação de que, "para a concessão de liminar possessória, não se faz necessário o requisito da urgência”, pelo que se admite na doutrina o atendimento da norma sem ressalvas, ${ }^{554}$ devendo ser considerada em tal hipótese, ainda, a sobreposição do interesse coletivo sobre a pretensão do autor, que indica a conveniência de se aguardar o contraditório para que a liminar seja concedida.

551 “Possessória - Reintegração de posse - Audiência - Justificação prévia - Oitiva de testemunhas de ambas as partes - Insurgência contra aquelas do réu, tendo em vista que somente o autor poderia arrolar testemunhas - Pretensão de que sejam desentranhados respectivos termos - Descabimento Possibilidade da tomada de depoimentos das testemunhas indicadas pelo réu - Exegese do art. 928, caput, segunda parte, do CPC e do art. 5. ${ }^{\circ}$, inciso LV, da CF - Princípio do contraditório - Hipótese em que a oitiva é realizada ao arbítrio do juiz, a fim de formar sua convicção para decidir - Pedido indeferido” (TJSP, Agravo de instrumento 990.10.063684-7, 18. ${ }^{a}$ Câm. Dir. Priv., DJ 18.05.2010).

552 ARRUDA ALVIM; ASSIS, Araken de; ALVIM, Eduardo Arruda. Comentários ao Código de Processo Civil, p. 1860.

553 BUENO, Cassio Scarpinella. Curso sistematizado de direito processual civil, v. 2, t. II, p. 77.

${ }^{554}$ ARRUDA ALVIM; ASSIS, Araken de; ALVIM, Eduardo Arruda. Comentários ao Código de Processo Civil, p. 1860. 
Muito embora se entenda pela constitucionalidade da referida norma, é certo que, em circunstâncias excepcionais, nas quais o autor demonstre não apenas os requisitos do artigo 927 do Código de Processo Civil, mas também a urgência relacionada ao caso concreto, consistente no risco de perecimento do direito, deve o juiz deferir a liminar de proteção da posse mesmo sem a oitiva da pessoa de direito público; em determinados casos, não há como sustentar que o prévio estabelecimento do contraditório possa comprometer o direito do autor. ${ }^{555}$

De qualquer forma, há de ser estabelecido com brevidade o contraditório viabilizador da liminar de proteção possessória, e por isso se afirma que "a citação é para que a requerida fale sobre o pedido de liminar; não é para contestar, porque esse prazo é muito longo e se o autor reclama a providência inicial é porque tem urgência na medida”. 556

Discorda-se, por isso, do entendimento de que a audiência de justificação deve ser realizada sempre que houver pedido de liminar contra pessoa jurídica de direito público, mesmo estando satisfatoriamente instruída a inicial, conforme defende Cláudia Aparecida Cimardi. ${ }^{557}$ Não é essa a regra do artigo 928, parágrafo único, do Código de processo Civil. Estando a inicial devidamente instruída, deve apenas ser ouvido o representante da pessoa jurídica de direito público, sendo desnecessária a realização da audiência, que tem como fim precípuo a produção de provas pelo autor.

Vale ressaltar que, tratando-se de bem já afetado ao interesse público, é inadmissível a proteção possessória em favor do particular, assim como a reivindicação, sendo assente na doutrina e na jurisprudência o entendimento de que a questão somente poderá se resolver com a indenização, por meio da denominada “desapropriação indireta”, ${ }^{558}$ Nessa hipótese, deverá o juiz julgar improcedente a demanda, porquanto não

\footnotetext{
555 BUENO, Cassio Scarpinella. Curso sistematizado de direito processual civil, v. 2, t. II, p. 76.

${ }^{556}$ FADEL, Sergio Sahione. Código de Processo Civil comentado, v. 2, p. 1145.

557 CIMARDI, Cláudia Aparecida. Proteção processual da posse, p. 298.

558 “Consumado o apossamento dos bens e integrados no domínio público, tornam-se, daí por diante, insuscetíveis de reintegração ou reivindicação, restando ao particular espoliado haver a indenização correspondente, da maneira mais completa possível, inclusive correção monetária, juros moratórios, compensatórios a contar do esbulho e honorários de advogado, por se tratar de ato caracteristicamente ilícito da Administração” (MEIRELLES, Hely Lopes. Direito administrativo brasileiro, p. 602).
} 
há ilicitude no ato de apropriação física do bem, mas entende-se que, por atenção ao princípio da economia, seria possível a conversão da ação de reintegração de posse em ação de indenização. ${ }^{559}$

\subsection{Defesa do réu nas ações possessórias}

Passada a fase inicial prevista no procedimento especial das ações possessórias, na qual as técnicas são voltadas para a apreciação e concessão, ou não, da liminar, e feita a citação - que, de modo peculiar, poderá ser realizada em conjunto com a intimação para a audiência de justificação, hipótese em que o prazo de 15 (quinze) dias para a apresentação de defesa será contado da intimação da decisão que deferir ou não a medida de urgência -, o procedimento passará a ser o comum ordinário, conforme se depreende da norma do artigo 931 do Código de Processo Civil.

Logo, se a ação possessória se voltar contra “força velha”, o procedimento será o comum ordinário desde o início, e, caso seja proposta contra ato praticado há menos de ano e dia, passará a ser ordinário o procedimento após o cumprimento do mandado liminar, ou em seguida ao seu indeferimento, não havendo qualquer peculiaridade no procedimento daí em diante. Excetua-se o caso em que o autor propõe a ação alegando força nova e, em seguida, na audiência de justificação, fica atestado que o ato de esbulho ou turbação já

\footnotetext{
"Desapropriação indireta é a que se processa sem observância do procedimento legal; costuma ser equiparada ao esbulho e, por isso mesmo, pode ser obstada por meio de ação possessória. No entanto, se o proprietário não o impedir no momento oportuno, deixando que a Administração lhe dê uma destinação pública, não mais poderá reivindicar o imóvel, pois os bens expropriados, uma vez incorporados ao patrimônio público, não podem ser objeto de reivindicação (art. 35 do Decreto-lei n. ${ }^{\circ}$ 3.365/41 e art. 21 da Lei Complementar n. 76/93)” (DI PIETRO, Maria Sylvia Zanella. Direito administrativo, p. 169).

559 “1. Não há violação do art. 535 do CPC quando o Tribunal de origem resolve a controvérsia de maneira sólida e fundamentada, apenas não adotando a tese do recorrente. 2. Trata-se de ação reintegratória ajuizada contra a Comlurb/RJ com a finalidade de recuperar a posse de imóveis contratualmente cedidos ao ente da administração indireta por tempo determinado. 3. A instância ordinária atestou que os imóveis estão afetados ao serviço público - servindo de aterro sanitário -, sendo, portanto, inviável a pretensão reintegratória. 4. Com a ocupação e a destinação do bem ao serviço público fica caracterizada a desapropriação indireta, remanescendo ao autor a buscar da indenização por danos, que no caso envolve responsabilidade de cunho contratual e extracontratual. 5. A jurisprudência desta Eg. Corte e do STF, com fundamento nos princípios da economia e celeridade além da tutela das obrigações de fazer, não fazer e entregar coisa certa distinta de dinheiro, consagrou a orientação de que é possível que a ação reintegratória seja convertida em ação de indenização por desapropriação indireta. 6. Na espécie, havendo pedido, é possível que a ação reintegratória seja convertida em ação de indenização em respeito aos princípios da celeridade e economia processuais. 7. Recurso especial parcialmente provido” (STJ, REsp

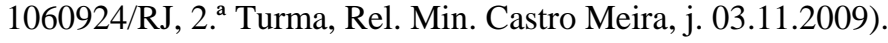


conta mais de ano e dia; nessa situação, mesmo tratando-se de força velha, o processo será iniciado pelo procedimento especial.

O artigo 297 do Código de Processo Civil refere-se a três formas de resposta do réu, quais sejam a contestação, por meio da qual poderá “deduzir todas as defesas que tiver contra o processo e contra o mérito da ação, com exceção daquelas matérias para as quais a lei prevê outras formas de alegação", ${ }^{560}$ as exceções e a reconvenção. A par dessa previsão legal, a doutrina ainda aponta outras formas de resposta do réu. Nesse sentido, Nelson Nery menciona, além dessas três já referidas, a ação declaratória incidental. ${ }^{561}$

Cassio Scarpinela Bueno ${ }^{562}$ aponta, no total, dez meios de defesa que são franqueados ao réu, dentre os quais se incluem, além daqueles quatro já registrados, o requerimento de desmembramento do litisconsórcio (art. 46, parágrafo único, CPC), a nomeação à autoria (arts. 62 a 69, CPC), a denunciação da lide (arts. 70 a 76, CPC), o chamamento ao processo (arts. 77 a 80), a impugnação ao valor da causa (art. 261) e o requerimento da justiça gratuita (art. 6. ${ }^{\circ}$, Lei 1.060/1950). Segundo o autor, o réu ainda pode se omitir de apresentar qualquer manifestação ou reconhecer juridicamente o pedido do autor, "posturas que não se consideram propriamente como respostas". 563

Heitor Vitor Mendonça Sica ainda inclui nesse extenso rol dos meios de defesa do réu o pedido contraposto, que classifica como "modalidade de reconvenção simplificada para o rito sumário e dos Juizados Especiais”, 564 e Cândido Rangel Dinamarco, embora não faça menção ao pedido de justiça gratuita e ao pedido contraposto, faz alusão à arguição de falsidade (art. 390, CPC). ${ }^{565}$

Algumas peculiaridades, porém, impõem-se à defesa nas ações possessórias, sejam elas conduzidas pelo procedimento especial (força nova) ou não (força velha).

\footnotetext{
${ }^{560}$ ARRUDA ALVIM; ASSIS, Araken; ALVIM, Eduardo Arruda. Comentários ao Código de Processo Civil, p. 670.

${ }^{561}$ NERY JUNIOR, Nelson; NERY, Rosa Maria de Andrade. Código de Processo Civil comentado, p. 678.

562 BUENO, Cassio Scarpinella. Curso sistematizado de direito processual civil, v. 2, t. II, p. 523-524.

563 SICA, Heitor Vitor Mendonça. O direito de defesa no processo civil brasileiro, p. 60.

564 Idem, ibidem.

565 DINAMARCO, Cândido Rangel. Instituições de direito processual civil, v. 3, p. 551.
} 
Estamos nos referindo a duas características de extrema importância que se atribuem aos interditos possessórios, quais sejam a existência de limitação objetiva à defesa do réu, consistente na vedação à exceção de domínio, que decorre da norma do $\S 2 .^{\circ}$ do artigo 1.210 do Código Civil, e o caráter dúplice, que, por força da norma do artigo 922 do Código de Processo Civil, autoriza o réu a demandar a proteção possessória e indenização na contestação, com fundamento na alegação de que foi ofendido em sua posse.

Em razão da limitação imposta pela lei à defesa do réu, que não poderá se fundar no domínio, é válida a lição de Eduardo Espínola, no sentido de que, ao réu da ação possessória, “duas ordens de defesa” de mérito são autorizadas:

[...] ou alegará que os atos que praticou são lícitos, como exercício de seus direitos, de acordo com o seu título [...] ou contestará a posse do autor, negando-lhe a qualidade do possuidor, ou provando que tem melhor posse, fundada em justo título, ou em consideração ao tempo de existência. ${ }^{566}$

Com isso, conclui-se que o réu, em sua defesa de mérito, estará limitado a se apoiar no seu direito de posse (ius possessionis), e não no “direito à posse” (ius possidendi), denominado pela doutrina como o direito fundado no domínio; vale dizer que o réu não poderá se opor à demanda do autor baseado simplesmente na alegação de domínio. Apesar da referida limitação, poderá o autor, na própria contestação, formular pedido de proteção possessória contra o autor, sem que, para tanto, seja necessária a apresentação de reconvenção. Esses temas relacionados à defesa nas ações possessórias serão abordados com maior profundidade nos tópicos seguintes.

\subsubsection{Demanda do réu em contestação (art. 922, CPC)}

Como visto, o artigo 922 do Código de Processo Civil dispõe que “é lícito ao réu, na contestação, alegando que foi ofendido em sua posse, demandar a proteção possessória e a indenização pelos prejuízos resultantes da turbação ou do esbulho cometido pelo autor”. Admitindo a legislação que a demanda do réu seja apresentada no bojo da própria defesa, refere-se a doutrina ao caráter dúplice da ação possessória e à possibilidade de

${ }^{566}$ ESPÍNOLA, Eduardo. Posse - Propriedade. Compropriedade ou condomínio. Direitos autorais. Conquista, p. 95. 
apresentação de pedido contraposto, ${ }^{567}$ que seria diferente da reconvenção, sob o aspecto formal, pela desnecessidade de apresentação da pretensão em peça apartada, nos moldes dos artigos 315 e seguintes do Código de Processo Civil.

Ressalte-se, porém, que a moderna doutrina vem demonstrando que não há diferença substancial entre a reconvenção e o pedido contraposto, sendo este, em verdade, uma técnica de facilitação da demanda do réu. ${ }^{568}$ Nesse sentido, Luis Guilherme Aidar Bondioli sustenta que o que a doutrina denomina pedido contraposto e a reconvenção, segundo sua concepção, são a mesma coisa, visto que são manifestações de um mesmo fenômeno, “qual seja a inserção em processo já instaurado de um novo pedido de tutela jurisdicional formulador pelo réu”. 569

Costuma-se atribuir às ações possessórias a natureza dúplice. Arruda Alvim afirma que o artigo 922 do Código de Processo Civil estabeleceu o caráter dúplice da ação possessória, e que “ação dúplice” “implica ser [...] possível que a proteção seja outorgada quer para o autor, ou, então, que essa proteção venha agasalhar a situação do réu”, 570

Em sentido contrário, Cláudia Cimardi sustenta que “as ações possessórias, porém, por essência, não têm natureza dúplice, sendo assim disciplinadas pelo sistema processual pátrio por determinação legal”. ${ }^{571}$ Explica a autora que a “duplicidade” das ações possessórias não lhes é inerente ou natural, mas sim resultado de previsão legal. Com

${ }^{567}$ Nesse sentido, utilizam a expressão "pedido contraposto" Antonio Carlos Marcato (Procedimentos especiais, p. 144.) e Nelton dos Santos (In: MARCATO, Antônio Carlos (Coord.). Código de Processo Civil interpretado, p. 2406).

${ }^{568}$ Ao tratar do tema, Heitor Vitor Mendonça Sica afirmou que "o pedido contraposto foi criado apenas com o intuito de simplificação dos procedimentos sumário e sumaríssimo (Juizados Especiais Estaduais), de modo que comportassem meio de contra-ataque do réu sem ampliar (e complicar) o objeto do processo". Segundo o autor, "essa novidade não criou novo meio, não autônomo, de contra-ataque do réu, a ser usado também no procedimento ordinário” (SICA, Heitor Vitor Mendonça. O Direito de Defesa no Processo Civil Brasileiro. p. 175).

569 “Afinal, trata-se de fenômeno substancialmente idêntico, qual seja a inserção em processo já instaurado de um novo pedido de tutela jurisdicional formulador pelo réu. A forma que serve de veículo para esse pedido do réu pouco importa para a caracterização do fenômeno reconvenção. Quer tal pedido venha veiculado na mesma peça da contestação, quer seja objeto de peça autônoma, o fenômeno é o mesmo" (BONDIOLI, Luis Guilherme Aidar. Reconvenção no processo civil, p. 37-38).

${ }^{570}$ ARRUDA ALVIM; ASSIS, Araken de; ALVIM, Eduardo Arruda. Comentários ao Código de Processo Civil, p. 1838.

${ }^{571}$ CIMARDI, Cláudia Aparecida. Proteção processual da posse, p. 172. 
isso, “ação dúplice” seria aquela em que, independentemente de qualquer pedido por parte do réu, pode ser possível que a ele seja atribuída a tutela jurisdicional. ${ }^{572}$ Dinamarco, ao conceituar nesse sentido as "ações dúplices", ${ }^{573}$ sustenta que, no processo civil brasileiro, são dúplices as ações de consignação de pagamento, de prestação de contas e de desapropriação.

Por seu turno, Adroaldo Furtado Fabrício conceitua a “ação dúplice” como aquela em que "dois sujeitos da relação jurídico-material e qualquer deles pode propor a mesma ação contra o outro". ${ }^{574}$ Por esse conceito, à primeira vista poderia parecer possível atribuir a natureza dúplice às ações possessórias, porquanto ambos os litigantes poderiam deduzir, um contra o outro, o mesmo pedido de proteção possessória.

No entanto, o pedido do réu não será idêntico ao do autor. Explica-se: genericamente, ambos pedirão a proteção possessória na hipótese em que o réu formular pedido contraposto, mas, afastado esse caráter genérico do objeto da demanda possessória, os pedidos jamais serão idênticos, pois, se o autor, estando na posse do bem, mover ação de manutenção ou de interdito, o réu só poderá demandar, em sua contestação, a reintegração, e, se movida ação de reintegração por quem não está na posse, o réu somente poderá demandar a proteção possessória por meio do pedido de manutenção ou de interdito proibitório, alegando, para tanto, que vem sendo molestado em sua posse. A corroborar tal pensamento, Adroaldo Furtado Fabrício afirma que os interditos possessórios não entram nessa categoria de juízos dúplices por natureza, ${ }^{575}$ e identifica tal duplicidade na ação demarcatória, visto que ambos os confrontantes poderiam assumir posição idêntica no processo.

Ao identificar os fenômenos que, por vezes, são indevidamente equiparados, Heitor Vitor Mendonça Sica ${ }^{576}$ conceitua como verdadeira “ação dúplice” aquela em que,

\footnotetext{
572 CIMARDI, Cláudia Aparecida. Proteção processual da posse, p. 2405.

573 “A diferença entre as ações dúplices e aquelas em que se admite o pedido contraposto está em que naquelas sequer um pedido precisa ser feito pelo réu, fosse em contestação, fosse onde fosse, para que o juiz possa dar-lhe a tutela jurisdicional plena” (DINAMARCO, Cândido Rangel. Instituições de direito processual civil, v. 3, p. 525).

${ }^{574}$ FABRÍCIO, Adroaldo Furtado. Comentários ao Código de Processo Civil, v. 8, t. III, p. 441.

575 Idem, ibidem, p. 441.

${ }^{576}$ SICA, Heitor Vitor Mendonça. O direito de defesa no processo civil brasileiro, p. 182.
} 
pela "natureza da relação de direito material a tutela outorgada ao autor pela procedência de sua demanda é idêntica àquela outorgada ao réu no caso de sua improcedência” e, apoiado na doutrina de Luis Guilherme Aidar Bondioli, ${ }^{577}$ diferencia-a de outros dois fenômenos, quais sejam a “contestação com conteúdo reconvencional”, que representa a possibilidade de formulação de demanda pelo réu na própria defesa, e os "efeitos legais da sentença”, que podem permitir ao réu receber tutela jurisdicional diferente da mera improcedência mesmo sem dedução de pedido.

Portanto, não se deve confundir a duplicidade das ações - em que a relação de direito material possibilita que o réu receba, com a improcedência da ação, independentemente de pedido, igual tutela àquela que receberia o autor no caso de procedência - com a possibilidade de o réu demandar na contestação, como ocorre nas ações possessórias, por força do artigo 922 do Código de Processo Civil.

Feita a distinção, pode-se denominar “exceção reconvencional” a defesa apresentada pelo réu com pedido de proteção processual, expressão utilizada pelo já citado autor Luis Guilherme Aidar Bondioli, que, no mesmo sentido, sustenta expressamente que, “ainda que o art. 922 não use a palavra reconvenção, é de uma demanda reconvencional que ele trata, pois inserção do pedido na mesma peça da contestação ou em peça própria não altera a essência do fenômeno”. ${ }^{578}$

Cassio Scarpilnella Bueno afirma que, por peculiaridade do direito material, a improcedência da ação possessória necessariamente implicaria a concessão de proteção possessória em favor do réu, e para tanto se baseia no entendimento de que "o reconhecimento de que não há esbulho na hipótese é significativo de tutela jurisdicional para o réu, que legitima, perante o Estado-juiz, a posse até então exercida”.

Entretanto, discorda-se de tal posicionamento. A mera improcedência da ação possessória não é suficiente para que ao réu seja outorgada a proteção processual; se assim fosse, não teria o legislador previsto a possibilidade de pedido de proteção pelo réu em contestação (art. 922, CPC). Na hipótese referida por Cassio Scarpinella Bueno, a

\footnotetext{
${ }^{577}$ BONDIOLI, Luis Guilherme Aidar. Reconvenção no processo civil, p. 29.

${ }^{578}$ Idem, ibidem, p. 29 e 65.
} 
improcedência da demanda pode implicar o reconhecimento de que o réu tem o direito de permanecer na posse, vinculando assim o bem litigioso à sua esfera de direitos. No entanto, esse fenômeno ocorre em qualquer sentença de improcedência. Ao analisar essa situação, Luis Guilherme Aidar Bondioli afirma que, com o fim do processo, o réu permanece nas mesmas condições em que se encontrava no momento do ajuizamento da demanda, e somente fica com a posse do bem porque já a tinha. ${ }^{579}$ E completa o autor sustentando que esse é um "resultado semelhante ao ordinariamente programado para todo processo que se encerra com sentença de improcedência”, e que “o réu não recebe sentença reconhecedora da sua posse nem fica livre de futura demanda possessória apoiada em distinta causa petendi”. ${ }^{580}$

O réu da ação de reintegração somente teria interesse para formular pedido de proteção processual se estivesse sendo turbado ou ameaçado em sua posse pelo autor. Neste caso, sua pretensão seria a de ser mantido na posse, por meio provimento jurisdicional que obrigasse o réu a não mais praticar atos de turbação ou ameaça.

Imagine-se, ainda, a situação daquele que, ao tentar retomar imóvel esbulhado depois de passado o momento em que seria legítimo o desforço, é acionado pelo ofensor por meio de ação de manutenção de posse; ainda que a pretensão do autor da ação seja julgada improcedente, o réu (possuidor esbulhado) não seria automaticamente reintegrado na posse do bem se não formulasse pedido expresso em sua contestação. Logo, se a pretensão do réu da ação de manutenção é a de retomar a posse por meio da reintegração, ou se a pretensão do réu da ação de reintegração é afastar a turbação ou a ameaça, deve ser formulado pedido nesse sentido, pois, do contrário, não será possível conceder a tutela possessória ao demandado. Ou seja, a tutela jurisdicional da posse somente será requerida pelo réu quando ele efetivamente estiver sofrendo ofensa.

A simples permanência na posse do bem é o que o réu espera com o acolhimento da sua defesa e a consequente improcedência da ação de reintegração de posse, sendo desnecessário, para tanto, formular pedido de proteção possessória na contestação. Nem mesmo neste caso haveria duplicidade, pois a sentença de procedência implicaria a

\footnotetext{
579 BONDIOLI, Luis Guilherme Aidar. Reconvenção no processo civil, p. 63.

${ }^{580}$ Idem, ibidem, p. 63.
} 
obtenção de uma ordem de restituição da coisa, por meio da qual o autor receberia a posse da coisa, ao passo que a sentença de improcedência não traria qualquer alteração ao réu, visto que ele continuaria na mesma situação, em relação ao bem litigioso, em que se encontrava antes do processo.

Em verdade, como ensina José Roberto dos Santos Bedaque, em toda sentença de improcedência se reconhece que o autor não tem direito à tutela jurisdicional e, por consequência, "tal provimento confere tutela ao réu, na medida em que lhe assegura o direito à integridade de sua esfera jurídica”. ${ }^{581}$ Logo, a efetiva proteção da posse outorgada ao réu da ação de reintegração, com o afastamento da turbação ou da ameaça, não equivale à sua permanência na posse do bem em razão da improcedência da ação. ${ }^{582}$ É oportuna, nesse passo, a lição de Luis Guilherme Aidar Bondioli:

[...] toda demanda tem uma certa carga dupla, na medida em que traz consigo sempre uma ação declaratória negativa do direito invocado pelo autor, apta a gerar para o réu sentença declaratória de igual teor na hipótese de improcedência daquela, independentemente da sua participação na relação jurídica processual, como visto logo acima. Nessas condições, emprestar o rótulo ação dúplice para a expressão de toda e qualquer duplicidade levaria à sua inutilidade, na medida em que ele colaria em toda e qualquer ação e seria insuficiente para a criação de uma categoria jurídica própria. ${ }^{583}$

Sendo assim, as ações possessórias somente gozam do que parte da doutrina denomina “caráter dúplice” em razão da previsão legal que autoriza o réu a demandar proteção possessória na própria contestação; fala-se, nessa hipótese, ainda, em “duplicidade processual”, pois, como visto, não fosse por tal dispositivo, os interditos não teriam natureza dúplice.

${ }^{581}$ BEDAQUE, José Roberto dos Santos. Direito e processo: influência do direito material sobre o processo p. 38.

${ }^{582}$ Como bem definiu Pontes de Miranda ao denominar o pedido do réu na ação possessória de "ação metida na contestação", o legislador permitiu que o réu, nas ações possessórias, em vez de apenas contestar o pedido de manutenção ou de reintegração, insira na contestação a contra-ação possessória e a ação de indenização". Afirmou o autor que "não se trata de simples contestação, a despeito de ser nela que se pode incutir o pedido possessório do réu” (PONTES DE MIRANDA, Francisco Cavalcanti. Comentários ao Código de Processo Civil, t. XIII, p. 195).

${ }^{583}$ BONDIOLI, Luis Guilherme Aidar. Reconvenção no processo civil, p. 56. 
Desse modo, a improcedência da ação possessória, "por si só, não representa tutela judicial dispensada à posse do demandado, o que, ocorrendo, poderia fornecer argumento favorável à defesa da duplicidade "natural” das ações possessórias. ${ }^{584}$ Importa notar que o legislador não autorizou a concessão da tutela processual da posse ao réu independentemente de pedido - o que naturalmente ocorreria nas verdadeiras "ações dúplices” -, e por isso a sua obtenção depende do expresso pedido. Manifestou tal entendimento João Batista Monteiro, ao asseverar que, não sendo dúplices por natureza as ações possessórias, o juiz não poderá outorgar a tutela ao réu se ele não a pediu, ou seja, “a ação será julgada improcedente, mas, na falta de pedido expresso e determinado do réu, não poderá ser-lhe tutelada a sua posse”. ${ }^{585}$

Essa constatação, aliás, fez firmar a jurisprudência do Superior Tribunal de Justiça no sentido de que "a pretensão do réu, de ver declarada, em seu favor, a posse do imóvel, nos termos do artigo 922 do CPC, porém, não foi ventilada na contestação oferecida; daí, por que, não há falar em ofensa aos dispositivos legais mencionados, em vista da preclusão ocorrida”. 586

Diante disso, pode-se afirmar que a possibilidade de concessão da tutela jurisdicional tanto em favor do autor quanto em favor do réu pode ser consequência natural do tipo de relação jurídica objeto da demanda (“ações dúplices”), ou também pode decorrer de imposição legal ${ }^{587}$ (art. 922, CPC), mas deve-se ressalvar que, apesar desse ponto em comum, não há, nesta última hipótese, a identidade qualitativa da tutela jurisdicional que poderá ser prestada a ambos os litigantes.

Ao réu da ação possessória é lícito, portanto, formular, em sua contestação, pedido de proteção possessória e de indenização resultante da ofensa à posse. São duas,

\footnotetext{
${ }^{584}$ FABRÍCIO, Adroaldo Furtado. Comentários ao Código de Processo Civil, v. 8, t. III, p. 442.

585 MONTEIRO, João Batista. Ação de reintegração de posse, p. 79.

${ }^{586}$ REsp 664.507-SP, 4. ${ }^{\text {a }}$ Turma, Min. Hélio Quaglia Barbosa, DJ 05.11.2007. No mesmo sentido: REsp 20626/PR, 3. ${ }^{\text {a } T u r m a, ~ M i n . ~ P a u l o ~ F u r t a d o, ~ D J ~ 29.10 .2009 . ~}$

587 No mesmo sentido, Nelson Nery Junior afirma que “o elemento novo na contestação da possessória pelo CPC vigente (indenização) faz com que a ação possessória não seja uma idêntica configuração da actio duplex do processo romano, mas se aproximando da actio contraria, de cunho notadamente reconvencional” (NERY JUNIOR, Nelson; NERY, Rosa Maria de Andrade. Código de Processo Civil comentado, p. 1391).
} 
portanto, as hipóteses de pedido admitidas em contestação, e a elas está limitada a demanda do réu em sede de defesa.

A indenização mencionada pelo dispositivo legal é aquela decorrente da turbação ou do esbulho, que, segundo Sergio Sahione Fadel, "será devida mesmo que a posse do autor, provisoriamente conseguida, decorra de mandado judicial”, 588 sendo indiferente, para a admissão desse pedido do réu, se pelo autor também foi pleiteada indenização.

Outra questão que desperta o debate na doutrina é aquela relacionada ao cabimento de reconvenção nas ações possessórias. A primeira reflexão sobre o tema pode conduzir à conclusão de que não é cabível o pedido reconvencional, porquanto a autorização prevista no artigo 922 do Código de Processo Civil já seria suficiente para atender às pretensões do réu. Ovídio Batista afirma que, em princípio, não há reconvenção em ação possessória, porquanto a contestação “já é naturalmente dotada de força reconvencional”. ${ }^{589}$ Marcos Destefenni ${ }^{590}$ sustenta que, nas ações possessórias, é permitido ao réu formular "pedido de proteção possessória ou de indenização, a seu favor, na própria contestação”, o que lhe retiraria o interesse em oferecer reconvenção para formular citados pedidos.

Não se pode afastar, todavia, o cabimento da reconvenção para fins outros que não sejam aqueles previstos no artigo 922 do Código de Processo Civil, quais sejam o pedido de proteção possessória e a indenização pelos prejuízos resultantes do esbulho e da turbação. ${ }^{591}$ Nessa mesma linha, Adroaldo Furtado Fabrício diz que, "para os efeitos do art. 922, a reconvenção é certamente inaceitável, por desnecessária”, mas destaca que, para deduzir outras pretensões, seria sim cabível o pedido reconvencional. Igualmente Antonio

\footnotetext{
${ }^{588}$ FADEL, Sergio Sahione. Código de Processo Civil comentado, v. 2, p. 1139.

589 THEODORO JÚNIOR, Humberto. Curso de direito processual civil, v. 3, 130.

590 DESTEFENNI, Marcos. Curso de processo civil, v. 3, p. 387.

${ }^{591}$ Pelo cabimento da reconvenção nas ações possessórias também já se manifestou o Superior Tribunal de Justiça: “Ação possessória. Reconvenção. Artigos 103, 315 e 922 do Código de Processo Civil. 1. A natureza dúplice da ação possessória, no rastro do art. 922 do Código de Processo Civil, não tem o condão de afastar, em tese, a possibilidade de reconvenção” (STJ, REsp 119775/SP, 3. ${ }^{a}$ Turma, Min. Carlos Alberto Menezes Direito, DJ 22.06.1998).
} 
Carlos Marcato sustenta que "pedidos de natureza diversa, não incluídos no dispositivo em pauta, só poderão ser veiculados por meio de reconvenção”. 592

Com razão a doutrina prevê a possibilidade de outras pretensões além daquelas dispostas na autorização do dispositivo legal em questão, por exemplo, a anulação de um contrato de compra e venda em razão da violação do direito de preferência, pleiteada pelo locatário que é demandado em ação de reintegração de posse. ${ }^{593}$

Alguns autores sustentam, inclusive, que os mesmos pedidos que podem ser cumulados pelo autor com o de proteção possessória poderiam também ser deduzidos pelo réu em contestação. ${ }^{594}$ No entanto, parece-nos que não se pode concluir por essa permissão, que não consta expressamente no artigo 922 do Código de Processo Civil, e nem seria lícita defendê-la sob o argumento de que às partes devem ser dadas oportunidades iguais, pelo simples fato de que, em diversos outros procedimentos, a falta de autorização para que o réu possa demandar em contestação não acarreta qualquer vício de ordem constitucional. Sendo assim, concorda-se com o posicionamento de Adroaldo Furtado Fabrício, que defende o cabimento da reconvenção para a formulação de pedido de cominação de pena para futuras agressões à posse e o desfazimento de plantações e construções, que são exatamente os pedidos que o autor pode cumular com o de proteção possessória. $^{595}$

\footnotetext{
${ }^{592}$ MARCATO, Antônio Carlos. Procedimentos especiais, p. 144.

593 “Agravo de instrumento. Reconvenção em ação possessória de imóvel. Reconvenção na qual se objetiva a anulação de compromisso de compra e venda do imóvel objeto da possessória com base em direito de preferência. Ilegitimidade passiva arguida por ré/reconvinda. Possibilidade da reconvenção em ação possessória se veicular outras pretensões que não aquelas previstas no art. 922 do CPC. Exame da ilegitimidade passiva arguida pela reconvinda, por não figurar na ação principal e no sentido de rescindida a locação, passa pelo exame de mérito como ressaltou a Juíza de Direito. Recurso negado" (TJSP, AI 0076506-37.2011.8.26.0000, 13. ${ }^{\text {a }}$ Câmara de Direito Privado, Rel. Francisco Giaquinto, DJ 31.08.2011).

594 “O réu somente poderá realizar pedido contraposto em harmonia com o art. 921 do CPC, uma vez que a cognição horizontal é limitada” (MEDINA, José Miguel Garcia; ARAÚJO, Fábio Caldas de; GAJARDONI, Fernando da Fonseca. Processo civil moderno. Procedimentos cautelares e especiais, v. 4, p. 280).

595 “[...] não se percebe motivo para que o réu se prive de pedir, se for o caso, também a cominação de pena para futuras agressões à posse e o desfazimento de plantações e construções” (FABRÍCIO, Adroaldo Furtado. Comentários ao Código de Processo Civil, v. 8, t. III, p. 443-444).
} 
É interessante notar que o direito à indenização por benfeitoria e o respectivo direito de retenção, previstos no artigo 1.219 do Código Civil, ${ }^{596}$ são admitidos pela jurisprudência como matéria a ser arguida em contestação. A formulação desses pedidos pelo réu em contestação, que antes da revogação do artigo 744 do Código Civil era requisito para admissibilidade dos embargos de retenção, na atualidade continua sendo admitido na jurisprudência, mesmo diante da considerada inadmissibilidade dos referidos embargos. $^{597}$

É evidente que, a despeito da alteração legislativa que tornou incabível a via dos embargos de retenção no cumprimento de sentença, continuam a existir o direito de indenização por benfeitorias e o respectivo direito de retenção, que poderão evidentemente ser reclamados pelo réu, a fim de que, reconhecidos pela sentença que julga procedente a ação que lhe é movida - ação de reintegração de posse, por exemplo -, possam ser satisfeitos não por meio de embargos de retenção, mas pela simples imposição de condição à exequibilidade da sentença.

Vale dizer, se foram acolhidos na sentença esses pedidos do réu, haverá condição a ser cumprida antes da execução, ${ }^{598}$ pelo que não poderá ser cumprida a sentença quanto à condenação à restituição da coisa enquanto não implementada pelo autor-devedor a obrigação de pagar a quantia arbitrada a título de indenização por benfeitoria.

Importa ressaltar, todavia, que, muito embora a doutrina ${ }^{599}$ e a jurisprudência ${ }^{600}$ sejam assentes em sustentar que o direito de retenção decorrente da fixação de indenização

596 “Art. 1.219. O possuidor de boa-fé tem direito à indenização das benfeitorias necessárias e úteis, bem como, quanto às voluptuárias, se não lhe forem pagas, a levantá-las, quando o puder sem detrimento da coisa, e poderá exercer o direito de retenção pelo valor das benfeitorias necessárias e úteis.”

597 “Embora a exposição de tal matéria continue possível em sede de contestação ou em embargos à execução (Código de Processo Civil, artigo 745, inciso IV), o exercício do direito de retenção é inadmissível por meio de embargos opostos contra título judicial (no caso dos autos, contra a sentença homologatória da transação celebrada entre as partes). Inadequada, assim, a via processual eleita pelos embargantes, de modo que era mesmo de rigor a extinção do processo sem resolução do mérito” (TJSP,

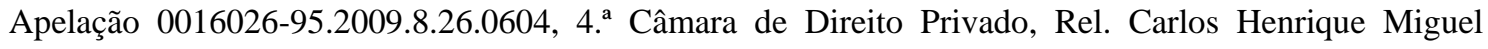
Trevisan, j. 16.08.2012, publ. 21.08.2012).

${ }^{598}$ Nesse sentido: THEODORO JÚNIOR, Humberto. Processo de execução e cumprimento da sentença, p. 593. DINAMARCO, Cândido Rangel. Instituições de Direito Processual Civil, v. 4, p. 254.

599 “O direito de retenção é uma exceção cabível em ações possessórias e petitórias” (LOUREIRO, Francisco Eduardo. Código Civil comentado, p. 1185). 
por benfeitoria deve ser arguido em contestação pelo réu da ação de reintegração de posse, como se se tratasse de matéria de defesa, a verdade é que representa pedido reconvencional que, pela lei (art. 922, CPC), não poderia ser apresentado em contestação, pois não há qualquer norma que autorize a sua apresentação em defesa, devendo ser deduzido na forma de reconvenção, por meio de petição apartada da contestação.

Não obstante tal constatação, de que é tecnicamente adequada a formulação do pedido de retenção por meio de reconvenção, direito que não se incluiu no rol daquelas pretensões que autorizam o pedido em contestação nas ações possessórias (art. 922, CPC), o caráter instrumental do processo deve prevalecer nessa situação para admitir tal pretensão se apresentada em contestação, desde que a prática deste ato em desacordo com a forma prescrita em lei (art. 297, CPC) não importe em prejuízo para a parte contrária e permita a correta compreensão do pedido reconvencional. ${ }^{601}$

Ainda em consideração à abrangência do pedido que é autorizado ao réu pela norma do artigo 922 do Código de Processo Civil, importa considerar que, apesar da divergência doutrinária, nada impede que seja concedida liminar nas ações possessórias em favor do demandado, caso tenha sido deduzido pedido de proteção possessória em sede de contestação. ${ }^{602}$

600 "Conforme maciça jurisprudência, a ação possessória, por seu caráter dúplice, comporta pedido contraposto de indenização e retenção pelas benfeitorias realizadas. Entretanto, se o réu não logrou comprovar as alegadas benfeitorias, o pleito não merece ser acolhido. 5. Apelo improvido" (TJDF, Ap 20020110351483, Rel. Humberto Adjuto Ulhôa, j. 04.12.2003, 4. ${ }^{a}$ Turma Cível). Acompanha o mesmo sentido o seguinte recente julgado do STJ: "Ora, se a Lei veda a oposição de embargos, reputando imprescindível que o pedido de retenção tenha sido formulado em contestação, durante o processo de conhecimento, não pode possibilitar que a mesma pretensão seja exercida em ação autônoma, permitindo que a parte obtenha o mesmo efeito vedado, por via transversa” (REsp 1.278.094/SP, 3. ${ }^{\text {a }}$ Turma, Rel. Min. Nancy Andrighi, DJ 16.08.2012).

601 "Dispõe o art. 297 do Código de Processo Civil que ela deve ser deduzida em peça separada da contestação, e isso é de toda conveniência para maior clareza e evitar tumultos; mas a inobservância dessa exigência legal constitui mera irregularidade formal que não prejudica nem conduz à nulidade do ato (art. 250) sempre que não dê causa a mal-entendidos (é preciso deixar claro onde termina uma resposta e principia a outra)" (DINAMARCO, Cândido Rangel. Instituições de direito processual civil, v. 3, p. 521).

602 "Possessória - Interdito proibitório - Preliminar de falta de interesse de agir que se confunde com o mérito da ação devendo ser por ora afastada - Elementos dos autos que indicam a mera detenção do imóvel pela autora-agravada - Concessão da liminar de reintegração de posse requerida pela agravada em pedido contraposto tendo em vista os atos da agravante que caracterizam a turbação - Recurso provido em parte” (TJSP, Agravo de Instrumento 0364715-32.2010.8.26.0000, Rel. J. B. Franco de Godoi, 23. ${ }^{\text {a }}$ Câmara de Direito Privado, j. 02.02.2011, publ. 21.02.2011). 
Adroaldo Furtado Fabrício defende entendimento contrário, sob o argumento de que não há previsão legal expressa que autorize o réu a deduzir pedido de liminar nas ações possessórias, e que o deferimento de tal medida após a contestação acarretaria o indesejável retorno à fase preliminar do processo. ${ }^{603}$ No mais, o doutrinador entende que não há interesse para a concessão de liminar ao réu, seja no caso de ter sido deferida liminar ao demandante - situação em que entende Adroaldo Furtado Fabrício que a revogação da liminar concedida ao autor somente poderia ser revogada por meio de agravo de instrumento -, seja na hipótese de lhe ter sido negado esse provimento de urgência.

No entanto, no tocante à hipótese de ter sido deferida liminar em favor do autor, mesmo que não tenha havido reforma por meio de agravo de instrumento, a apresentação da defesa traz novos fatos que permitem ao juiz inverter a situação posta pela liminar; não se trata de mera revogação da liminar concedida ao autor, mas sim de revisão a partir de fatos novos trazidos pelo réu. Por outro lado, caso tenha sido negada a liminar ao autor da ação de manutenção de posse, por exemplo, pode o réu demandar reintegração e formular pedido de liminar nesse sentido, o que demonstra sem sombra de dúvidas o seu interesse.

Ademais, seria contrário ao sistema processual imaginar que a tutela jurisdicional, que o réu está autorizado a pedir em sua contestação, não pudesse ser antecipada, ${ }^{604}$ pelo que se conclui que é perfeitamente lícita a concessão de liminar de proteção possessória ao réu. , além ser impositiva, pelo prisma processual, a possibilidade de concessão de liminar ao réu da ação possessória, negá-la representaria, conforme asseverou Humberto Theodoro Junior, afronta ao direito de acesso ao devido processo legal (CF, art. 5. ${ }^{\circ}$, incs. XXXVI, LIV e LV). ${ }^{605}$

\footnotetext{
603 “A faculdade outorgada ao réu não autoriza concessão a ele de liminar possessória. A contestação alcança o procedimento já ordinarizado; o retorno à fase preliminar, por hipótese já vencida, representaria perturbação grave e desnecessária” (FABRÍCIO, Adroaldo Furtado. Comentários ao Código de Processo Civil, v. 8, t. III, p. 445).

604 “[...] à medida que o réu pode formular pedido, pleiteando a proteção possessória, deve esta abranger a tutela de mérito e a tutela liminar" (CIMARDI, Cláudia Aparecida. Proteção processual da posse, p. 176).

${ }^{605}$ THEODORO JÚNIOR, Humberto. Curso de direito processual civil, p. 131.
} 


\subsubsection{Vedação à exceção de domínio}

Como já demonstrado em tópico anterior (item 3.1), Ihering sustentou, em sua conhecida teoria objetiva, que a posse seria nada mais do que uma exteriorização da propriedade, e que, por isso, a sua proteção seria um “complemento necessário da proteção da propriedade, uma facilidade de prova em favor do proprietário”, ${ }^{606}$ porquanto entendia o autor que a prova da posse seria mais fácil do que a do domínio. ${ }^{607}$

Conclui-se, portanto, que Ihering enxergava na proteção da posse um benefício ao proprietário, que não precisaria travar uma batalha sobre o seu direito de propriedade para afastar um reles “ladrão”. E assim, para garantir esse benefício ao proprietário, Ihering entendia necessária a vedação da defesa com fundamento na propriedade, pois, caso isso ocorresse, o proprietário teria que comprovar o seu domínio e, com isso, perderia o benefício.

O raciocínio é tortuoso, pois, sob o pretexto de garantir a proteção da propriedade, admite-se que um "ladrão” se valha da proteção possessória contra o proprietário, tudo para garantir o benefício da possibilidade da posse ao proprietário. ${ }^{608}$

Clóvis Beviláqua ${ }^{609}$ registrou a celeuma que envolveu a redação do artigo $505^{610}$ do Código Civil de 1916. Segundo o autor do código revogado, a regra da vedação da

${ }^{606}$ IHERING, Rudolf von. O fundamento dos interditos possessórios, p. 71.

${ }^{607}$ Esse pensamento de Ihering, de que seria mais fácil a prova da posse do que a da propriedade, não poderia ser transposto para o nosso sistema jurídico vigente na atualidade, em que se dispõe de um regime tabular eficaz e seguro. Para viabilizar tal raciocínio, Ihering faz menção, por exemplo, à dificuldade da prova do domínio de escravos. Contudo, apesar da evidente sustentabilidade dessa tese na atualidade, a intenção do presente estudo é apenas a de demonstrar o motivo que levou o autor alemão a defender a vedação à exceção de domínio. Deve-se registrar, no entanto, que, como ressaltado pela doutrina, “a comprovação do domínio, nos países que não adotaram o regime de transmissão da propriedade pelo registro, ainda é um problema, como na Itália, na França e em Portugal” (MEDINA, José Miguel Garcia; ARAÚJO, Fábio Caldas de; GAJARDONI, Fernando da Fonseca. Processo civil moderno. Procedimentos cautelares e especiais, v. 4, p. 277).

608 "Mais vale que um velhaco excepcionalmente partilhe de um benefício da lei, que ver este benefício recusado a quem o merece - isto somente para excluir o primeiro [...] A facilidade de prova para a proteção possessória tem em vista vantagens para o proprietário; em regra, só ao proprietário aproveita essa facilidade; falsearia o intuito dessa facilidade admitir-se na ação uma discussão sobre ser ou não ser o autor proprietário” (IHERING, Rudolf von. O fundamento dos interditos possessórios, p. 90-94).

${ }^{609}$ BEVILÁQUA, Clóvis. Código Civil dos Estados Unidos do Brasil, v. 1, p. 986. 
exceção de domínio, embora fosse mundialmente aceita, tratava-se de norma processual, e não elementar da relação jurídica. Quanto à segunda parte do referido dispositivo, Clóvis Beviláqua afirmou que reproduziu o Assento de 16 de fevereiro de $1786,{ }^{611}$ consagrando um princípio modificativo dessa regra geral. Asseverou o autor que alguns doutrinadores da época, como Juvenal Lamartine, defendiam que, se no pensamento de Ihering “é o interesse da propriedade que justifica a defesa da posse, em vez de contrária à doutrina do grande romanista, é um corolário dela a exceção em favor do domínio”. ${ }^{612}$ Contrariamente teria se manifestado Astolpho Rezende, condenando a segunda parte do referido dispositivo, o que não impediu, entretanto, de prevalecer a “modificação da regra geral” da segunda parte do revogado artigo 505 do Código Civil de 1916.

Ou seja, a regra prevista na segunda parte do referido dispositivo revogado baseou-se em dois equívocos: primeiro, por considerar que a exceção do domínio era favorável à teoria de Ihering, pois basta a leitura de sua obra para entender que é exatamente a vedação dessa exceção que fundamenta sua tese; ${ }^{613}$ o segundo equívoco decorre do pensamento de que seria possessória a ação em que ambas as partes litigam com fundamento no domínio, o que, como já se afirmou (item 4.2), representaria verdadeira “ação petitória”, identificável pela causa de pedir e pelo pedido, pouco importando o rótulo que lhe fora atribuído. ${ }^{614}$

610 “Art. 505. Não obsta a manutenção, ou reintegração na posse, a alegação de domínio, ou de outro direito sobre a coisa. Não se deve, entretanto, julgar a posse em favor daquele a quem evidentemente não pertencer o domínio.”

${ }^{611}$ Humberto Theodoro Júnior explica que as Ordenações Filipinas, fiéis às tradições das fontes romanas, condenavam o esbulho, mesmo que cometido pelo dono da coisa. Segundo o autor, o Alvará de 09.11.1754 teria feito previsão que, sem objetivar alterar o regime das Ordenações, gerou erro de interpretação que culminou na equivocada reprodução da norma no Assento de 16 de fevereiro de 1786, donde teria se originado toda a discussão que levou o autor do Código Civil de 1916 a autorizar, indiretamente, a exceção do domínio (THEODORO JÚNIOR, Humberto. Curso de direito processual civil, p. 128).

612 BEVILÁQUA, Clóvis. Código Civil dos Estados Unidos do Brasil, v. 1, p. 987.

${ }^{613}$ Nesse sentido: “Grave foi que o autor do Projeto do Código Civil de 1916, e outros, ao seu tempo, tivessem acreditado em que a admissão da exceptio domini é consequência necessária da teoria de Rudolf von Ihering: não no é” (PONTES DE MIRANDA, Francisco Cavalcanti. Comentários ao Código de Processo Civil, t. XIII, p. 200).

614 “Ação em que se reclama direito à posse com base em domínio é ação petitória e não possessória. Logo, A Súmula n. 487, em última análise, acabou por excluir das verdadeiras ações possessórias a possibilidade de exceção.” 
Assim, segundo o pensamento do autor do Código Civil de 1916, a exceção do domínio somente pode ser invocada quando “a posse disputada se apresentar como exterioridade do domínio do possuidor” e quando, “evidentemente, o domínio não pertence ao contendor”. Nas palavras de Clóvis Beviláqua, a hipótese prevista para aplicação da referida norma era aquela "em que duas pessoas pretendem a posse a título de proprietárias, e manda que, se, em relação a uma delas, falhar, evidentemente, esse pressuposto, a favor dela se não julgue a posse, pois lhe falta o fundamento”.

Esse entendimento norteou a jurisprudência, culminando na edição da Súmula do Supremo Tribunal Federal 487, originada do RE 59.943 de 1966, com a seguinte redação: "Será deferida a posse a quem evidentemente tiver o domínio, se com base neste for ela disputada”.

Em seguida, como advento do Código de Processo Civil de 1973, afirmou-se, na doutrina, que seu artigo $923^{615}$ teria substituído a regra do artigo 505 do Código Civil. Todavia, como ponderou Humberto Theodoro Junior, a redação do referido dispositivo da lei processual, em vez de resolver a questão, era ainda mais desastrosa do que a do artigo 505 do Código Civil, pois, enquanto este advertia que a posse não deveria ser conferida a quem evidentemente não era possuidor, o novo dispositivo "expressava o comando no imperativo: a posse será julgada em favor daquele a quem evidentemente pertencer o domínio". 616

Posteriormente, a segunda parte do artigo 923 do Código de Processo Civil foi revogada pela Lei 6.820/1980, e a partir daí surgiu o entendimento de que teria também sido revogada a norma da segunda parte do artigo 505 do Código Civil de $1916 .{ }^{617}$ Desde então, foi extirpada do sistema jurídico brasileiro a exceção de domínio nas ações

615 “Art. 923. Na pendência do processo possessório é defeso, assim ao autor como ao réu, intentar ação de reconhecimento do domínio. Não obsta, porém, à manutenção ou à reintegração na posse a alegação de domínio ou de outro direito sobre a coisa; caso em que a posse será julgada em favor daquele a quem evidentemente pertencer o domínio."

${ }^{616}$ THEODORO JÚNIOR, Humberto. Curso de direito processual civil, p. 127.

${ }^{617}$ Nesse sentido: MARINONI, Luiz Guilherme; ARENHART, Sérgio Cruz. Procedimentos especiais, p. 95. E também: THEODORO JÚNIOR, Humberto. Curso de direito processual civil, p. 127. 
possessórias, e o $§ 2 .^{\circ}$ do artigo 1.210 do Código Civil ${ }^{618}$ harmonizou-se com a norma do artigo 923 do Código de Processo Civil, de modo a eliminar qualquer dúvida quanto à vedação da exceção do domínio.

Por conseguinte, não tem mais qualquer aplicabilidade às ações possessórias a Súmula 487 do Supremo Tribunal Federal. Afirma-se na doutrina que, "para se dar utilidade à referida súmula, é preciso sustentar que a exceção de domínio é permitida na ação petitória”, ${ }^{619}$ situação que seria verificada na hipótese de o autor da ação reivindicatória pleitear a recuperação da posse com fundamento no domínio e o réu apresentar defesa fundada na propriedade.

Contudo, em relação às ações possessórias, é inquestionável a expressa vedação legal da exceção de domínio (art. 1.210, § 2. ${ }^{\circ}$, CC). Trata-se de reserva de cognição, ${ }^{620}$ ou, como denominou Kazuo Watanabe, "limitação horizontal à cognição”, ${ }^{621}$ que delimita a matéria de defesa a ser apresentada pelo réu, técnica de limitação à cognição que "não atenta às garantias constitucionais da isonomia e do contraditório”. ${ }^{622}$ Portanto, na hipótese de ajuizamento de ação possessória - corretamente fundamentada na posse -, não poderá o réu se defender com fundamento no domínio, “o que implica a consagração, agora completa, do princípio da separação entre possessório e petitório”. ${ }^{623}$

Apesar disso, é corrente a afirmação, arraigada no velho conceito que prevalecia quando da elaboração do Código Civil de 1916, de que é possível a exceção do domínio

618 “§ 2. ${ }^{\circ}$ Não obsta à manutenção ou reintegração na posse a alegação de propriedade, ou de outro direito sobre a coisa."

${ }^{619}$ MEDINA, Luiz Guilherme; ARENHART, Sérgio Cruz. Procedimentos especiais, p. 96.

620 “O juízo da ação possessória, para realmente viabilizar o alcance da tutela possessória, não pode se permitir discussões inerentes ao domínio, sob pena de a tutela jurisdicional, que deveria ser outorgada à posse, ser deferida sempre em favor do proprietário. Note-se que o possuidor esbulhado pelo titular do domínio sequer teria razão para propor ação de reintegração de posse, já que o proprietário demandado sempre receberia, em seu favor, a tutela jurisdicional. [...] Outrossim, a Súmula 487 do Supremo Tribunal Federal, ao afirmar que 'será deferida a posse a quem, evidentemente, tiver o domínio, se com base neste for ela disputada’, não tem mais qualquer aplicabilidade diante das ações possessórias” (MARINONI, Luiz Guilherme; ARENHART, Sérgio Cruz. Procedimentos especiais, p. 96).

${ }^{621}$ WATANABE, Kazuo. Da cognição no processo civil, p. 41.

622 SICA, Heitor Vitor Mendonça. O direito de defesa no processo civil brasileiro, p. 286.

${ }^{623}$ FABRÍCIO, Adroaldo Furtado. Comentários ao Código de Processo Civil, v. 8, t. III, p. 463. 
nas ações possessórias quando com fundamento no domínio a posse for disputada. ${ }^{624}$ Também sustentando a possibilidade de julgamento da ação possessória com fundamento no domínio, Antonio Carlos Marcato defende que, se ambas as partes disputam a posse com base na alegação de domínio, o juiz deverá decidir em favor daquela que prove a titularidade do domínio. Nesse caso, segundo o autor, a sentença não reconhece a propriedade, mas simplesmente concede a proteção possessória à parte que demonstrou, com base no domínio, ser legítima possuidora. ${ }^{625}$ Já Ovídio A. Baptista da Silva ${ }^{626}$ assevera que "a chamada exceptio domini poderá, em determinadas hipóteses, emergir nas ações possessórias”, como no caso em que a posse se apresenta duvidosa ou insuficiente para autorizar o julgamento fundado apenas na controvérsia sobre a posse.

Em relação à primeira hipótese aventada na tentativa de sustentar a possibilidade de exceção de domínio nas ações possessórias, parece-nos que, ou se está diante de uma ação petitória com o "rótulo" de algum dos interditos - e aí valeria a assertiva de que, “como a causa de pedir é a propriedade, a ação não é possessória, mas petitória”627 -, ou está-se admitindo a possibilidade de exceção de domínio em evidente afronta à vedação legal, visto que deferir à parte vencedora "a tutela possessória, por haver demonstrado, com base no domínio, ser legítima possuidora”, é admitir a exceção do domínio, pouco

624 “Processual civil. Reintegração de posse. Art. 535. Violação. Inexistência. Art. 499 do CC/1916. Prequestionamento. Ausência. Súmulas n. 282 e 356 do stf. Exceção de domínio. Art. 505 do CC/1916. Alegação. Inviabilidade. Restrição. Hipótese que ambas as partes disputam a posse com base no melhor título de domínio. Súmula n. 487/STF. O Tribunal de origem não emitiu juízo de valor sobre a matéria à luz do art. 499 do Código Civil, e a autarquia sequer aviou embargos de declaração com o fim de prequestioná-lo. Tal circunstância atrai a incidência das Súmulas n. 282 e 356 do STF. Conheço, pois, do recurso especial apenas quanto ao art. 505 do Código Civil de 1916, que trata da exceção de domínio. Ao compulsar os autos, constata-se que o Tribunal de origem, de modo conciso, mas claro, e com base nas provas dos autos, decidiu toda a controvérsia posta em debate, ou seja, afastou o pedido da autarquia de reintegração na posse com base no título. O julgador não precisa se ater a todos os argumentos das partes para decidir, basta que, de modo suficiente, fundamente seu decisum. Não caracteriza, portanto, violação ao art. 535 do CPC, a circunstância do acórdão atacado ter solvido a lide contrariamente à pretensão da parte, hipótese presente no caso dos autos. Na mesma linha deste Tribunal Superior, o julgador de primeiro grau dirimiu a lide sob o fundamento da 'melhor posse', eis que a exceção de domínio restringese àquelas hipóteses em que ambos os contendores disputam a posse fundada na propriedade (Súmula n. 487/STF), o que não ocorreu no caso dos autos. Conforme constatado pela instância inferior, apenas a autarquia recorrente sustentava sua posse com respaldo no título de domínio, o que extirpa a incidência da exceptio domini na presente demanda. Recurso especial conhecido, em parte, e improvido” (REsp 671115-RJ, 2. ${ }^{\text {a }}$ Turma, Rel. Min. Castro Meira, j. 15.06.2005, publ. DJ 15.08.2005, p. 271).

625 MARCATO, Antônio Carlos. Procedimentos especiais, p. 145.

${ }^{626}$ SILVA, Ovídio A. Baptista da. Curso de processo civil, p. 189.

${ }^{627}$ NERY JUNIOR, Nelson; NERY, Rosa Maria de Andrade. Código de Processo Civil comentado, p. 1394. 
importando se a sentença declara ou não o domínio, pois o que se veda é a defesa fundamentada no domínio.

É certo que a prova da propriedade pode corroborar a comprovação da posse, se aliada a outros elementos de fato, e comumente o título de domínio acompanha a inicial das ações possessórias movidas por proprietários-possuidores, com a finalidade de complementar a prova dos fatos. Entretanto, o domínio, por si só, não é suficiente para comprovar a posse; do direito de propriedade não decorre, necessariamente, a posse. E nem se deve entender, nesse caso, que o autor está demandando a proteção possessória com fundamento do domínio, só por ter apresentado na inicial a escritura de compra e venda; o domínio, nessa situação, não é a causa de pedir, mas apenas o reforço da prova da posse, que deverá evidentemente ser demonstrada por outros meios.

Em relação ao entendimento de Ovídio A. Baptista, considera-se que, se não há provas suficientes para julgar a ação possessória com fundamento só na controvérsia sobre a posse, o caminho a ser trilhado será o da improcedência da ação - assim como o do pedido contraposto, se houver. Nessa hipótese, deverá a parte que se julga detentora do domínio buscar a via petitória, de modo a resolver a questão dominial.

Em resumo, é correto o entendimento de que a "Súmula 487 do STF aplica-se apenas às ações reais e não às possessórias”, ${ }^{628}$ muito embora se constate que o Superior Tribunal de Justiça tem aplicado a referida súmula às ações possessórias quando ambos os litigantes discutem a posse com fundamento no domínio. ${ }^{629}$

Quanto à vedação do artigo 923 do Código de Processo Civil, de ajuizamento de ação de reconhecimento de domínio na pendência de processo possessório, o Supremo

${ }^{628}$ ARRUDA ALVIM; ASSIS, Araken de; ALVIM, Eduardo Arruda. Comentários ao Código de Processo Civil, p. 1847.

629 “[...] Embora na pendência de processo possessório não se deve intentar ação de reconhecimento do domínio (art. 923 do CPC), constatada a sobreposição de documentos registrais, sob perícia de que os autores têm menos área que prevê seu título de propriedade em confronto com o título apresentado pelos réus, é plenamente cabível a exceção de domínio, se, com base neste, ambos os litigantes discutem a posse. 3. Incidência, no caso, da Súmula n. 487 do STF, assim expressa: 'Será deferida a posse a quem evidentemente tiver o domínio, se com base neste for disputada”' (REsp 906.392/MT, 4. ${ }^{\text {a Turma, DJ }}$ 18.03.2010). 
Tribunal Federal já se manifestou pela sua constitucionalidade. ${ }^{630}$ Tem-se, com essa norma, um reforço à vedação de exceção de domínio, de modo a evitar que o réu afaste a pretensão do autor por meio do pedido de reconhecimento de domínio formulado em nova demanda.

Pela leitura do texto legal, não há dúvidas de que, na pendência de demanda possessória, é absolutamente vedada a propositura, por qualquer das partes, de ação que tenha por objeto o reconhecimento do direito de propriedade, devendo o juiz extinguir a ação nessa situação com fundamento no artigo 267, inciso IV, do Código de Processo Civil, em razão da ausência de pressuposto processual, ${ }^{631}$ e não apenas suspender, porquanto não se trata de mera prejudicialidade. No entanto, a doutrina, pela mesma dificuldade enfrentada para aceitar a proibição da exceção do domínio na ação possessória, tenta impor limites à vedação do ajuizamento de ações fundadas em domínio na pendência do processo possessório, sob o fundamento de que a negação absoluta representaria afronta ao direito de propriedade e prejuízo de um de seus componentes elementares, que é o poder de reivindicar. ${ }^{632}$

Pontes de Miranda afirmou que "seria absurdo que, pela simples pendência de ação possessória, que pode ir até o julgamento de recursos, ficasse o proprietário privado do exercício da pretensão à tutela jurídica”. ${ }^{633}$ Nelson Nery sustenta que esse dispositivo legal "não limita o exercício dos direitos constitucionais de propriedade e de ação (RTJ

630 “Concorrência de ações. Ação de reivindicação e ação possessória. Trancamento da ação de reivindicação com base na interpretação literal da primeira parte do artigo 923 do Código de Processo Civil. Aplicandose a hipótese o artigo 308, VII, do regimento interno, e havendo sido rejeitada a arguição de relevância, o recurso extraordinário só poderá ser apreciado no que diz respeito a alegação de ofensa ao artigo 153, caput e parágrafo 22, da Emenda Constitucional n. 1/69. Não é inconstitucional o artigo 923, 1. ${ }^{a}$ parte, do Código de Processo Civil, não o sendo também a interpretação literal que lhe deu o acórdão recorrido. Recurso extraordinário não conhecido” (RE 87.344/MG, Min. Moreira Alves, DJ 16.10.1978).

631 “Também é 'pressuposto processual' negativo, específico para as demandas em que se pretende o reconhecimento de domínio (ações petitórias), a pendência de processo possessório em que se discuta esse domínio” (DIDIER JR., Fredie. Pressupostos processuais e condições da ação, p. 173).

${ }^{632}$ FABRÍCIO, Adroaldo Furtado. Comentários ao Código de Processo Civil, v. 8, t. III, p. 452.

${ }^{633}$ PONTES DE MIRANDA, Francisco Cavalcanti. Comentários ao Código de Processo Civil, t. XIII, p. 199. 
91/594), mas vem ao propósito da garantia constitucional e legal de que a propriedade deve cumprir sua função social (CF 5. ' XXIII, 170 III; CC 1228 §1. ․)”. 634

Nesse sentido, Adroaldo Furtado Fabrício defende que a absoluta vedação da propositura de ação petitória poderia estimular o ajuizamento de ações possessórias com o propósito de prolongar a situação de fato que talvez contrarie o direito, na medida em que o proprietário ficaria impedido de reivindicar a coisa que lhe pertence em razão da pendência de ação possessória. Essa completa vedação prestigiaria, segundo o autor, “o artifício malicioso e a chicana da pior espécie”. 635

E, na busca da correta interpretação da norma do artigo 923 do Código de Processo Civil, Adroaldo Furtado Fabrício distingue as “ações possessórias fundadas no domínio (vale dizer, aquelas em que as partes disputam a posse a título de donos)” daquelas outras em que “a posse é objeto único e exclusivo do debate” para, em seguida, afirmar que somente seria possível na segunda hipótese o ajuizamento de ação fundada no domínio, porquanto no primeiro caso a questão do domínio já seria objeto da cognição, sendo “desnecessária e perturbadora a propositura paralela da ação petitória, em que se agitaria, ao fim e ao cabo, a mesma questão". 636 No entanto, considerando o autor a mudança legislativa implementada pelo artigo 1.210, § 2. ${ }^{\circ}$, do Código Civil de 2002, sustenta que, não mais havendo a possibilidade de exceção de domínio nas ações possessórias, não haveria mais propósito em negar a admissibilidade das ações de domínio na pendência do processo em que, por regra, deve-se discutir apenas a posse.

Ou seja, entende o autor que a vedação do artigo 923 do Código de Processo Civil visava apenas a repudiar litispendência, a fim de evitar a desnecessária propositura de ação fundada em domínio se sobre este direito já se fundamentava a ação possessória pendente. Entretanto, agora, admitindo que não é mais possível a exceção de domínio nas ações possessórias, sustenta que não há qualquer razão que impeça a propositura da ação fundada em domínio na pendência do processo possessório.

\footnotetext{
${ }^{634}$ NERY JUNIOR, Nelson; NERY, Rosa Maria de Andrade. Código de Processo Civil comentado, p. 1394.

${ }^{635}$ FABRíCIO, Adroaldo Furtado. Comentários ao Código de Processo Civil, v. 8, t. III, p. 455.

${ }^{636}$ Idem, ibidem, p. 456.
} 
Contudo, o objetivo da norma do artigo 923 do Código Civil, a toda evidência, não é e nunca foi o de impedir a repetição de demandas idênticas, mas sim o de evitar que o réu da ação possessória se defenda indiretamente por meio da propositura de ação fundada em domínio, ou seja, o que pretendeu o legislador, com essa norma, sobretudo após o advento da Lei 6.820/1980, que revogou a sua segunda parte, foi garantir a completa vedação da exceção de domínio.

Por isso, considerando as razões históricas que fundamentam a vedação da exceção de domínio, andou bem o legislador ao proibir, por meio da norma do artigo 923 do Código de Processo Civil, o ajuizamento de ação de reconhecimento de domínio, ${ }^{637}$ por qualquer das partes da ação possessória, enquanto estiver pendente o seu processamento, ${ }^{638}$ pois seria contraditório um sistema que, ao mesmo tempo em que veda a exceção de domínio nas ações possessórias, autoriza o ajuizamento de ações fundadas em domínio na pendência daquelas, as quais certamente serviriam de defesa indireta do réu ao pedido de proteção possessória; tal contradição, portanto, é que conduziria à “chicana” processual.

Apesar de ser lógica e coerente a absoluta vedação contida no artigo 923 do Código de Processo Civil, os tribunais ainda não alcançaram a pacificação da questão e, pelos mesmos motivos que ainda se admite a exceção de domínio nas ações possessórias em determinadas situações, a jurisprudência também impõe limitações à aplicação da referida norma, ${ }^{639}$ muito embora alguns julgados interpretem corretamente a norma em questão. ${ }^{640}$

${ }^{637}$ Deve-se entender por ação fundada em domínio aquela que tem como causa de pedir o ius possidendi, ou seja, o direito à posse decorrente de outros direitos, como o do compromissário comprador.

${ }^{638}$ No mesmo sentido: CIMARDI, Cláudia Aparecida. Proteção processual da posse, p. 205.

639 “Agravo retido e apelação cível. Ação reivindicatória. Extinção do processo, sem julgamento do mérito, sob o fundamento de que o pedido é juridicamente impossível. Nulidade da sentença. Inteligência do artigo 923 do Código de Processo Civil. Existência de ação possessória que somente impede o curso da reivindicatória nas hipóteses em que a disputa da posse seja realizada a título de domínio. Hipótese dos autos em que não é impugnada a propriedade do bem pelo autor. Retorno dos autos à Vara de Origem para regular prosseguimento da ação. De ofício, anula-se a sentença, com determinação, prejudicados os

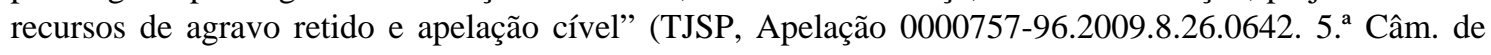
Direito Privado, Rel. Des. Christine Santini, DJ 29.03.2012).

${ }^{640}$ Superior Tribunal de Justiça: “Na pendência do processo possessório é vedado tanto ao autor como ao réu intentar a ação de reconhecimento de domínio, nesta compreendida a ação de usucapião" (REsp 171.624/MG, Rel. Min. Barros Monteiro, 4. ${ }^{\mathrm{a}}$ Turma, j. 29.06.2004, DJ 18.10.2004, p. 279). Tribunal de Justiça do Estado de São Paulo: "Usucapião especial. Ação ajuizada na pendência de processo 
Em relação à ação de usucapião, é questionado na doutrina o seu enquadramento no conceito de "ação fundada em domínio" para os fins da vedação imposta pelo artigo 923 do Código de Processo Civil. Cláudia Cimardi sustenta que a ação de usucapião, embora busque o reconhecimento do domínio, por meio da sentença meramente declaratória, não teria o condão de, por si só, afastar a proteção possessória. ${ }^{641}$ Ou seja, mesmo que seja julgada procedente a ação de usucapião em favor daquele que é réu em ação de reintegração de posse, tal julgamento, no juízo possessório, em nada influiria. Com isso, pretende a autora distinguir a "ação de reconhecimento de domínio" que tenha o efeito de automaticamente entregar a coisa litigiosa ao proprietário, como no caso da ação reivindicatória, da “ação de reconhecimento de domínio” cuja sentença não teria “o condão de modificar ou resguardar o exercício de um poder de fato". ${ }^{642}$

É coerente a tese da autora, pois, se o que se pretende afastar com a vedação da exceção de domínio - seja na defesa da ação possessória, seja pelo ajuizamento de ação de reconhecimento de domínio ajuizada na pendência do processo possessório - é a possibilidade de julgamento da ação possessória com fundamento no direito de propriedade, ou, em outras palavras, a outorga da proteção da posse ao proprietário com fundamento exclusivamente no seu domínio, e se eventual sentença de procedência da ação de usucapião não interfere diretamente, pelo reconhecimento do domínio, no julgamento da ação possessória pendente, poder-se-ia afirmar que a vedação do artigo 923 do Código de Processo Civil não se aplicaria à ação de usucapião.

No entanto, a jurisprudência do Superior Tribunal de Justiça não acolhe essa tese, e nega o cabimento da ação de usucapião na pendência de ação possessória, ${ }^{643}$ mas a

possessório. Impossibilidade jurídica do pedido. Exegese do artigo 923 do Código de Processo Civil. Processo extinto sem resolução do mérito. Sentença mantida. Recurso não provido” (Apelação 919763067.2007.8.26.0000, 5. ${ }^{\text {a }}$ Câmara Dir. Priv., Rel. Des. Erikson Gavazza Marques, DJ 16.05.2012).

641 “Não entendemos deva ser incluída a ação de usucapião como ação de reconhecimento de domínio, para os fins do art. 923 do CPC. Isso porque, apesar de ser ação declaratória de existência de domínio, e, a rigor, encaixar-se na classe de 'ações de reconhecimento de domínio, não comporta pedido de restituição ou manutenção de um estado de fato correspondente ao exercício sobre a coisa, ou seja, a posse”, (CIMARDI, Cláudia Aparecida. Proteção processual da posse, p. 206-207).

${ }^{642}$ Idem, ibidem, p. 206-207).

643 “Usucapião. Propositura da ação na pendência de processo possessório. Inadmissibilidade. Art. 923 do Código de Processo Civil. Na pendência do processo possessório é vedado tanto ao autor como ao réu intentar a ação de reconhecimento de domínio, nesta compreendida a ação de usucapião. Recurso especial 
jurisprudência admite, com fundamento na Súmula 237 do Supremo Tribunal Federal, ${ }^{644}$ de 1963, a alegação de usucapião em defesa na ação possessória. ${ }^{645}$

Nesse passo, importa identificar as situações que, apesar de relacionadas à exceção de domínio, conduzem a conclusões diversas: (i) alegação de domínio em contestação de ação possessória com a pretensão de, sob o exclusivo fundamento no domínio, obter a proteção da posse; (i) ajuizamento de ação de reconhecimento de domínio - “ação reivindicatória”, por exemplo - na pendência do processo possessório com o objetivo de obter a proteção possessória; (ii) o ajuizamento de ação de usucapião na pendência de processo possessório com o objetivo único de obter declaração de domínio; e (iii) alegação de posse ad usucapionem na contestação da ação possessória com o objetivo de vencer a disputa da posse, com fundamento na posse, e não em razão da usucapião.

Parece-nos que as duas primeiras hipóteses representam a exceção de domínio vedada pelos artigos 1.210, § 2. ${ }^{\circ}$, do Código Civil, e 923 do Código de Processo Civil, respectivamente, e pelas razões já expostas entendemos que não devem ser admitidas.

Quanto à terceira hipótese, que trata do ajuizamento de ação de usucapião na pendência do processo possessório, igualmente entendemos que haveria afronta à norma do artigo 923 do Código de Processo Civil. Muito embora esteja correta Cláudia Cimardi quanto à afirmação de que a sentença meramente declaratória da ação de usucapião não tem o condão de influenciar diretamente na ação possessória para, com fundamento no domínio reconhecido, favorecer o proprietário com a proteção possessória sob o fundamento exclusivo no domínio, é inevitável constatar que o legislador proibiu

conhecido e provido” (RESP 171624-MG 1998/0029217-9, Rel. Min. Barros Monteiro, j. 28.06.2004, 4. ${ }^{\text {a }}$ Turma, publ. DJ 18.10.2004, p. 279, RSTJ 195/336).

644 “O usucapião pode ser arguido em defesa.”

645 “Possessória. Reintegração de posse. Improcedência. Alegação de invasão do imóvel pertencente ao demandante. Posse anterior deste não provada. Imóvel que permaneceu por muito tempo desocupado pela demandante, configurando estado de abandono. Esbulho não configurado. Aquisição da propriedade do imóvel insuficiente para ensejar a proteção possessória postulada. Requisitos do art. 927 do CPC não demonstrados. Improcedência da ação que deve ser mantida. Recurso da autora improvido. Possessória. Admissibilidade da alegação de usucapião como matéria de defesa. Descabimento, contudo, de seu reconhecimento no julgamento da lide, com a declaração de domínio em favor da contestante. Recurso desta também improvido” (TJSP, Apelação 0132906-70.2008.8.26.0002, 14. . Câmara de Direito Privado, Rel. Thiago de Siqueira, j. 25.07.2012, publ. 01.08.2012). 
expressamente o ajuizamento de ação de reconhecimento de domínio, que é exatamente o caso da ação de usucapião, na pendência de ação possessória.

No tocante à quarta hipótese identificada, é admissível alegar, em defesa na ação possessória, a posse ad usucapionem, não, porém, para pedir a declaração de usucapião e, consequentemente, o reconhecimento do domínio - o que representaria a exceção vedada pelo legislador -, mas simplesmente para comprovar o direito de posse (ius possessionis) que fundamentará a improcedência da ação. Portanto, a alegação da posse ad usucapionem como matéria de defesa na ação possessória não equivale a alegar o domínio, mas simplesmente importa em demonstrar as qualidades da posse do réu para afastar a pretensão à tutela processual da posse requerida pelo demandante. ${ }^{646}$

Costuma-se utilizar a expressão "melhor posse” como resquício da norma do artigo 507 do Código Civil, ${ }^{647}$ que estabelecia critérios objetivos para determinar qual dos litigantes teria a melhor posse. Por ela, seria considerada melhor posse aquela fundada em justo título e, na falta de título, ou sendo os títulos iguais, a mais antiga; caso, entretanto, fossem fundadas em títulos iguais e da mesma data, deveria ser escolhida a posse atual. Se ainda assim não houvesse certeza, seria a coisa sequestrada até que se apurasse a quem caberia a posse.

Esse critério, porém, não era justo, porquanto a parte que tivesse posse nova "só poderia fazer prevalecer a sua posse em face de alguém que não conseguisse, por qualquer um dos critérios cogitados pelo Código, demonstrar sua superioridade no exercício possessório”. ${ }^{648}$ O Código Civil de 2002 não reproduziu a referida norma do código anterior, visto que, atualmente, além da verificação do título hábil, deverá ser observado, no caso concreto, o atendimento à função social da posse, imposição decorrente da

646 "Permitir que tal alegação seja feita, contudo, não significa dizer que o réu pode pretender efetivamente ver reconhecida sua propriedade com a rejeição do pedido do autor [...] a sentença que reconhece a posse do réu como bastante para fins de usucapião não pode ser tida como título hábil para o registro imobiliário" (BUENO, Cassio Scarpinella. Curso sistematizado de direito processual civil, v. 2, t. II, p. 78).

647 “Art. 507. Na posse de menos de ano e dia, nenhum possuidor será manutenido, ou reintegrado judicialmente, senão contra os que não tiverem melhor posse. Parágrafo único. Entende-se melhor a posse que se fundar em justo título; na falta de título, ou sendo os títulos iguais, a mais antiga; se da mesma data, a posse atual. Mas, se todas forem duvidosas, será sequestrada a coisa, enquanto se não apurar a quem toque."

${ }^{648}$ TEPEDINO, Gustavo. Comentários ao Código Civil, v. 14, p. 151. 
Constituição Federal de 1989 que acarretou mudança drástica no conceito de "melhor posse”.

Assim, o que se busca desvendar nas ações possessórias é a quem deve ser garantida a situação da posse, isto é, qual dos litigantes tem a “melhor posse” para receber do Estado a proteção processual. E somente por isso é que se admite a alegação de posse ad usucapionem, porque nela se encontram os elementos que atestam o respeito à função social da posse e da propriedade. ${ }^{649}$ Admite-se a alegação de posse ad usucapionem em defesa nas possessórias, portanto, não pelo domínio que pode ser declarado a partir dela em ação de usucapião, mas pela posse em si mesma.

\subsection{Sentença das ações possessórias}

Nos subitens a seguir expostos, analisaremos as classificações das tutelas jurisdicionais, demonstrando as divergências da doutrina acerca da matéria, com o objetivo de classificar o provimento final das ações possessórias, o que será fundamental para a correta compreensão da forma de cumprimento da sentença e da postura do executado nesta fase.

\subsubsection{Classificação das tutelas jurisdicionais}

A doutrina clássica convencionou classificar a “ação”, e até mesmo o “processo”, levando em consideração a natureza da atividade jurisdicional e o tipo de tutela jurisdicional pleiteada pelo demandante. Tal concepção remonta a uma fase em que o

649 “Não é raro observarmos tensões entre a posse e a propriedade, decorrentes de situações em que imóveis são abandonados por seus titulares, sendo que possuidores passam a exercitar ingerência socioeconômica sobre o bem. Há um evidente conflito entre garantias essenciais em nosso sistema constitucional. De um lado, o direito fundamental à propriedade (art. 5. ${ }^{\circ}$ XXII, da CF); de outro, a função social da propriedade que, apesar de omitida pelo titular formal, é concedida por um possuidor, ao deter poder fático sobre o bem (art. 5. ${ }^{\circ}$ XXIII, da CF). Esta tensão será por vezes solucionada pela lei (e.g., usucapião) ou pelo magistrado ao ponderar a dimensão dos interesses conflituosos na situação concreta. Em qualquer caso, se formos coniventes com a noção da posse reduzida a direito real, invariavelmente estaremos submetendo-a preconceituosamente ao império da propriedade, reduzindo a sua enorme importância social [...] Todavia, quando é analisada a função social da posse há um plus no estudo da matéria. Aqui, não se preocupa com a trajetória isolada do proprietário e o seu compromisso com o atendimento a direitos fundamentais. Aprecia-se a atuação fática de um possuidor sobre a coisa que o titular patrimonial desvinculou de qualquer função social” (FARIAS, Cristiano Chaves de; ROSENVALD, Nelson. Direitos reais, p. 38-39). 
processo civil, embora já compreendido como ciência autônoma em relação ao direito material, ainda não havia fixado com exatidão os conceitos que hoje são tão caros aos processualistas. ${ }^{650}$

Sustenta Cassio Scarpinella Bueno, entretanto, que "a ação não tem porque receber qualificações ou adjetivações”, ${ }^{651}$ visto que se trata da possibilidade de pleitear ao Estado-juiz a prestação de tutela jurisdicional. Portanto, partindo da premissa de que "a classificação da ação e do processo é feita em função da tutela pleiteada pelo autor”, 652 mostra-se correto que o objeto da classificação seja a tutela jurisdicional.

Com isso, é a tutela jurisdicional, portanto, e não a "ação" ou o "processo", que deve ser classificada em conhecimento, executiva e cautelar. Não representa equívoco, ${ }^{653}$ todavia, a atribuição de tais denominações à sentença, visto que indicam, em verdade, a tutela que se pretende produzir por meio desse ato do juiz.

Fixados tais conceitos, dedicar-nos-emos à análise da tutela de conhecimento, que a doutrina clássica convencionou classificar, levando em conta a sua natureza, em meramente declaratória, constitutiva e condenatória - concepção “ternária” -, o que indica que as crises jurídicas surgidas são solucionadas por essas diferentes modalidades de tutela cognitiva, que podem ser divididas de acordo com as diversas situações de direito material.

Por meio da sentença meramente declaratória, elimina-se a crise de certeza, tornando indiscutível a existência ou inexistência de relação jurídica, ou a autenticidade ou falsidade do documento (art. 4. ${ }^{\circ}$, CPC), por força da coisa julgada. A proteção conferida pela tutela declaratória é plena, pois dispensa a realização de qualquer providência

650 João Mendes de Almeida Junior, ao tratar sobre as “ações”, em sua obra escrita no início do século passado, dividiu-as "segundo a disposição dos atos no seu modo de operar, isto é, segundo a tendência e disposição dos atos processuais”, em ação ordinária, sumária, especial executiva e sumaríssima, o que demonstra que, naquele período, ainda se chamada de "ação" o que hoje denominamos procedimento (Direito judiciário brasileiro, p. 112).

${ }^{651}$ BUENO, Cassio Scarpinella. Curso sistematizado de direito processual civil, v. 1, p. 345.

${ }^{652}$ BEDAQUE, José Roberto dos Santos. Efetividade do processo e técnica processual, p. 509.

653 Cassio Scarpinella Bueno afirma que sequer a sentença merece classificação, visto não se confundir com a tutela pleiteada. Confira-se: “melhor do que restringir o problema à 'ação' ou a um específico 'ato processual' (sentença), parece mais proveitoso tratar dos efeitos [...] como formas diferenciadas de prestação da tutela jurisdicional” (BUENO, Cassio Scarpinella. Curso sistematizado de direito processual civil, v. 1, p. 346). 
posterior para satisfazer da pretensão reclamada pelo autor, a exemplo do que ocorre na investigação de paternidade, em que se busca apenas o reconhecimento do vínculo entre pai e filho.

A ação constitutiva implica uma modificação (criação, modificação ou extinção) na relação jurídica e, do ponto de vista prático, opera automaticamente tal modificação no plano substancial, satisfazendo integralmente, também, a pretensão trazida a juízo. A sentença de natureza constitutiva possui um grau de efetividade tão elevado que é apta a realizar o resultado prático esperado, exigindo, em alguns casos, a denominada execução imprópria, consistente na realização de atos materiais que, embora sejam necessários para a integral satisfação do direito, não chegam a caracterizar uma execução. ${ }^{654}$

Já a ação condenatória destina-se à concessão de tutela que afirme a existência do direito e obrigue o réu a cumprir - prestar - determinado ato comissivo ou omissivo. Assim, “com a procedência da demanda, o juiz ordena alguém a dar, fazer ou não fazer (pagar uma soma de dinheiro, entregar certo bem móvel, desocupar determinado bem imóvel etc.)”. ${ }^{65}$ Portanto, como toda sentença de mérito, a condenatória contém uma declaração, mas o que a diferencia dos demais provimentos (declaratório e constitutivo) é seu segundo momento lógico, ${ }^{656}$ que abre as portas para a execução, criando condições para que o autor busque a satisfação de seu direito por essa via.

Pela tradição do ordenamento jurídico brasileiro, a sentença condenatória é a que depende de execução; ${ }^{657}$ é o que a doutrina era assente em denominar de título executivo

654 "Não constituem execução, porque não incluem pressão sobre a vontade de um sujeito nem se realizam mediante sub-rogação de atividades, os atos de documentação de sentenças e acórdãos, às vezes exigidos em lei para a eficácia destes. É o caso do registro da sentença que julga procedente a ação de usucapião (CPC, art. 945) ou das de anulação de casamento, divórcio ou separação judicial (LD, art. 32, e LRP, art. 100 ) etc. Os assentos registrários dessas decisões não são medidas constritivas nem se realizam com o objetivo de invadir o patrimônio de um sujeito; por isso, não se enquadram no sistema da execução forçada. Mas, sendo aptos a consumar os resultados estabelecidos pelo direito e desejados pelo vencedor, eles corporificam uma execução em sentido lato e, daí, serem corretamente identificados como atos de execução imprópria (Liebman)" (DINAMARCO, Cândido Rangel. Instituições de direito processual civil, v. 4, p. 35).

${ }^{655}$ LUCON, Paulo Henrique dos Santos. Eficácia das decisões e execução provisória, p. 158.

${ }^{656}$ DINAMARCO, Cândido Rangel. Instituições de direito processual civil, v. 3, p. 234.

${ }^{657}$ Apesar da inovação trazida pelo artigo 475-N, inciso I, do Código de Processo Civil, que possibilita a interpretação de que, no direito positivo brasileiro, seria também título executivo a sentença meramente declaratória, mostra-se mais lógico, em vez de tentar equiparar a eficácia da tutela declaratória à da 
por excelência, pois a estrutura do provimento condenatório não é suficiente para dar ao credor a satisfação plena do direito nela reconhecido - a tutela jurisdicional plena -, que continua a depender ou do cumprimento voluntário do devedor, ou, caso não haja, das medidas executivas.

A doutrina clássica do Brasil e de diversos outros países ${ }^{658}$ sempre fez referência a essa classificação ternária, reconhecendo três espécies de “ações de conhecimento”, com base nas tutelas buscadas por meio delas. Segundo Enrico Tullio Liebman, ${ }^{659}$ além de condenatória, poderia a sentença ser também declaratória ou constitutiva, e no caso de improcedência seria sempre declaratória; o autor apontou a tripartição como "resultado da cuidadosa análise das diversas espécies de sentença e de seus possíveis conteúdos”. No mesmo sentido, Moacyr Amaral Santos classificava as sentenças em meramente declaratórias, constitutivas ou condenatórias. ${ }^{660}$ Affonso Fraga também seguia essa “divisão tripartita”,661 das ações declarativas, de condenação e constitutivas.

José Ignacio Botelho de Mesquita acompanhou tal nomenclatura não por considerar que ela traduz efetivamente o conteúdo de cada uma das espécies de sentença, mas sim, afirma o autor, porque “a simples mudança de denominações, além de ter contra

condenatória, aceitar a ideia de que a declaração, por si só, prescinde de execução, e que o referido dispositivo legal não conferiu pretensão a executar à simples declaração, mas sim ao provimento declaratório que reconhece uma obrigação com todos os seus elementos formadores. Assim, ao se admitir a execução dos provimentos declaratórios por força da norma do aludido dispositivo legal, é certo que somente poderá ser utilizada como título executivo judicial a declaração que reconhecer a violação a um direito e identificar os sujeitos, a prestação, a liquidez e a exigibilidade da obrigação. Ou seja, "de nada adianta afirmar que toda e qualquer sentença declaratória pode dar início à execução se a liquidez e a exigibilidade do pretenso título não estiverem presentes” (YARSHELL, Flávio Luiz; BONÍCIO, José Magalhães. Execução civil, p. 95); apenas poderia formar título executivo a sentença que reconhece a existência de uma obrigação (pagar, fazer ou não fazer ou de entregar coisa).

658 “Nell'ambito della tutela giurisdizionale dichiarativa, secondo una tradizionale tripartizione, la parte può chiedere al giudice, predeterminando così il contenuto della sentenza, una tutela di mero accertamento del diritto, un provvedimento di condanna e una tutela constitutiva” (COMOGLIO, Luigi Paolo; FERRI, Corrado Ferri; TARUFO, Michele. Lezioni sul proceso civile, p. 626). No mesmo sentido: "El proceso de cognición puede conducir a una providencia de fondo (en general, teniendo la forma de la sentencia; véase n. 77) mediante la cual se realiza en concreto uno de los siguientes remedios procesales: a) declaración de mera certeza; b) condena; c) declaración de certeza constitutiva” (MICHELI, Gian Antonio. Derecho procesal civil, v 1, p. 49).

${ }^{659}$ LIEBMAN, Enrico Tullio. Eficácia e autoridade da sentença, p. 280.

${ }^{660}$ AMARAL SANTOS, Moacyr. Direito processual civil, v. 3, p. 52.

${ }^{661}$ FRAGGA, Affonso. Instituições do processo civil, v. 1, p. 248. 
si a força de uma poderosa tradição na ciência processual, não implicaria alteração quanto ao objeto do [...] estudo", 662

Não seguiu esse pensamento, porém, o autor brasileiro Pontes de Miranda, que desenvolveu a classificação das “ações” em cinco espécies - a denominada “teoria quinária das ações” -, segundo a carga preponderante de eficácia da sentença, que coloca, ao lado dos provimentos declaratórios, constitutivos e condenatórios, as chamadas sentenças mandamentais e executivas - ou executivas lato sensu, como prefere a doutrina moderna. $^{663}$

Segundo o entendimento desse doutrinador, as sentenças seriam portadoras de cinco cargas de eficácia, quais sejam declarativa, constitutiva, condenatória, mandamental e executiva, e o que as diferenciaria seria a preponderância de uma destas cargas sobre as demais. Pontes de Miranda defendeu que as classificações de ações de que usaram os juristas europeus estariam superadas, pois não resistiam às críticas e concorriam para confusões enormes, porquanto "não viam que uma coisa é força de sentença (eficácia preponderante) e outra a eficácia imediata ou a mediata”. 664

Para o autor brasileiro, o que mais importa ao conceito de ação condenatória é que "a eficácia mediata ou imediata seja a de declaratividade, ou imediata ou mediata a de executoriedade”. Ao resumir seu entendimento, Pontes de Miranda afirmou que “a sentença de condenação não executa - permite a execução; tampouco, manda que se cumpra a prestação - abre portas a que se peça a execução e o juiz executor execute” ${ }^{665}$

Assim, a sentença executiva (lato sensu) surge, inicialmente, para diferenciar dos provimentos condenatórios as sentenças que não exigem execução ex intervallo, vale dizer, que não exigem a instauração de um processo de execução autônomo. Nas palavras de Pontes de Miranda, “nas sentenças de eficácia executiva imediata não se precisa de propor

\footnotetext{
${ }^{662}$ BOTELHO DE MESQUITA, José Ignacio. Teses, estudos e pareceres de processo civil, v. 1, p. 107.

663 'Em todo caso, repita-se, não era usual na obra a expressão 'ação executiva lato sensu'. Tampouco tinha Pontes de Miranda - e é o que mais importa aqui, para desfazer o equívoco - o costume de usar a locução 'sentença executiva lato sensu'. Falava de sentença executiva, tout court' (BARBOSA MOREIRA, José Carlos. Temas de direito processual. Nona série, p. 180).

${ }^{664}$ PONTES DE MIRANDA. Tratado das ações, t. I, p. 118.

${ }^{665}$ Idem, ibidem, t. V, p. 5.
} 
outra ação: o elemento 4 de executividade permite que nos mesmos autos se execute o que resulta da eficácia executiva”. 666

A eficácia mandamental diferencia-se das demais, na concepção de Pontes de Miranda, porque "tem por fito preponderante que alguma pessoa atenda, imediatamente, ao que o juízo manda”. ${ }^{667}$ Segundo o autor em referência, “a eficácia mandamental imediata aparece em ações de alta relevância no mundo jurídico”, por exemplo, na ação de “manutenção provisória” e nos embargos de terceiro. ${ }^{668}$

O elemento que poderia diferenciar a dita sentença executiva lato sensu das demais tutelas condenatória seria, portanto, a dispensa do processo de execução autônomo para a efetivação do julgado, tendo em vista que se encontra na própria sentença a determinação para a realização prática do ato necessário à efetivação do comando da sentença condenatória; essa parece ser a característica mais marcante dessa categoria de sentença.

Contudo, se somente por esse aspecto pudesse ser classificada com autonomia a ação executiva, então, com o advento do "processo sincrético" para as sentenças que obrigam a pagar quantia, fazer e não fazer ou entregar coisa, não haveria mais ação condenatória, uma vez que todas as sentenças seriam executivas pela simples dispensa do processo de execução autônomo.

Cândido Rangel Dinamarco afirma que ainda persiste uma única diferença entre as sentenças denominadas "executivas lato sensu” e as demais tutelas condenatórias, que é a "eficácia de dispensar a iniciativa da parte para que a execução tenha início". ${ }^{669}$ Não nos parece correto, todavia, admitir que a sentença dita “executiva lato sensu” teria a "eficácia peculiar de autorizar a execução de ofício”, ${ }^{670}$

\footnotetext{
${ }^{666}$ PONTES DE MIRANDA. Tratado das ações, t. VII, p. 57.

${ }^{667}$ Idem, ibidem, t. VI, p. 4.

668 Idem, p. 6.

${ }^{669}$ DINAMARCO, Cândido Rangel. Instituições de direito processual civil, v. 3, p. 251.

${ }^{670}$ Idem, ibidem, p. 251.
} 
É certo que o cumprimento de sentença que condena ao pagamento de quantia, pelo que se depreende da norma do $\S 5 .^{\circ}$ do artigo 475-J do Código de Processo Civil, somente se inicia com a iniciativa da parte. Em relação ao cumprimento de obrigação de entrega de coisa, considerando que o juiz só terá conhecimento de que tal obrigação não foi cumprida espontaneamente se avisado pelo vencedor, não seria possível a "execução de ofício”, dado que o § 2. ${ }^{\circ}$ do artigo 461-A do Código de Processo Civil autoriza a expedição do mandado de busca e apreensão ou de imissão na posse quando "não cumprida a obrigação no prazo estabelecido”.

Quanto à sentença da ação de reintegração de posse (condenação de entrega de coisa), a que se atribui essa denominação executiva lato sensu, vale notar que não há na lei qualquer disposição que expressamente dispense a iniciativa da parte para o início do cumprimento. E nem se alegue que a disposição do artigo 929 do Código de Processo Civil (“julgada procedente a justificação, o juiz fará logo expedir mandado de manutenção”) autoriza o cumprimento da sentença sem a iniciativa da parte; nesta hipótese, o Código está se referindo à liminar, e não à sentença. Sempre houve dispensa da instauração de novo processo para execução da sentença, mas não da iniciativa da parte para deflagrar a execução, e sequer seria lógica tal dispensa, visto que o juiz pode não ter conhecimento de eventual cumprimento espontâneo pelo vencido.

Nesse sentido, José Carlos Barbosa Moreira sustenta que, ao ângulo processual, a única diferença perceptível é a que consiste na contraposição entre a necessidade de dois processos consecutivos (sentença condenatória) e a suficiência de um único processo (sentença executiva lato sensu) para a satisfação prática da parte vitoriosa, e prossegue defendendo que tal insuficiência decorre da lei, pois seria perfeitamente concebível que uma alteração legislativa modificasse a efetivação da norma sentencial, o que, de certa forma, aconteceu com o advento das Leis 10.444/2002 e 11.232/2005, que acabou com a autonomia do processo de execução para a efetivação da sentença judicial ${ }^{671}$ - à exceção das sentenças penal, arbitral e estrangeira (art. 475-N, parágrafo único, CPC), cuja execução teve sua autonomia preservada, valendo anotar, ainda, que não se alterou o procedimento da execução contra a Fazenda Pública (art. 730, CPC).

${ }^{671}$ BARBOSA MOREIRA, José Carlos. Temas de direito processual. Nona série, p. 193. 
Buscando captar da obra de Pontes de Miranda, em nível mais profundo, o critério científico da distinção entre sentença condenatória e sentença executiva, José Carlos Barbosa Moreira destaca a seguinte passagem:

[...] e o critério para determinar-se se uma certa demanda deve ser condenatória ou executiva lato sensu [...] está em que, nas primeiras, a demanda contida no processo de conhecimento não decide sobre a legitimidade ou ilegitimidade da posse exercida pelo condenado sobre o bem que será afetado pela atividade executiva, na demanda subsequente de execução forçada; enquanto nas execuções lato sensu a questão da legitimidade da posse do demandado faz parte da res in iudicio deducta da ação que, se não fosse isso, seria condenatória. ${ }^{672}$

O que parece ter justificado, portanto, em última análise, a criação da categoria das denominadas ações executivas lato sensu é o fato de o bem da vida sobre o qual recairá a tutela jurisdicional integrar o patrimônio do demandante, e que, por isso, não haveria execução para invasão do patrimônio do devedor.

Seguindo esse entendimento, Ovídio Baptista discorda que o direito processual possa conceder contra o devedor que será executado para "pagar com o que lhe pertence” uma sentença idêntica àquela favorável ao titular do domínio para reaver o bem que se encontra com o usurpador, ${ }^{673}$ e defende que a sentença condenatória é marcada pela relação obrigacional, e que por isso difere da sentença executiva lato sensu, que acolhe “pretensões a haver coisa”. ${ }^{674}$ No mesmo sentido, Gledson Marques de Campos afirma que, pertencendo ao executado a coisa a ser buscada "não se está diante de execução, porque nesta, mesmo após a citação e penhora, o executado continua a ter domínio dos bens sobre os quais incidirão os atos executórios”, ${ }^{675}$ e defende a necessidade de tratamento processual diverso às obrigações de entrega e de restituição.

No entanto, não previu o legislador a diferença de tratamento processual pretendida pelos referidos autores, e por isso esse pensamento por eles manifestado deve

\footnotetext{
672 BARBOSA MOREIRA, José Carlos. Temas de direito processual. Nona série, p. 192.

${ }^{673}$ SILVA, Ovídio A. Baptista da. Jurisdição e execução na tradição romano-canônica, p. 46.

674 SILVA, Ovídio A. Baptista da. Curso de processo civil, v. 1, t. II, p. 44

${ }^{675}$ CAMPOS, Gledson Marques de. Ação autônoma de execução para a entrega de coisa. In: CIANCI, Mirna; QUARTIERI, Rita (Coord.). Temas atuais da execução civil em homenagem ao Professor Donaldo Armelin, p. 259.
} 
ser tomado apenas como crítica ao sistema vigente, e não como fundamento para a criação de subespécies de sentenças condenatórias.

Cassio Scarpinella Bueno explica que a tutela condenatória reclama a prática de atos sub-rogatórios sobre o patrimônio do devedor, e é justamente nessas técnicas de subrogação que ela se caracteriza como tal, distinguindo-se, em razão disso, das tutelas executiva e mandamental, nas quais não seria necessária a "transformação do patrimônio do devedor em dinheiro” para satisfazer o direito do credor. ${ }^{676}$ No entanto, essa diferença, a rigor, não pode sustentar a distinção entre a sentença condenatória e a denominada sentença executiva lato sensu, dado que também na adjudicação, que é a forma preferível de expropriação admitida no cumprimento de sentenças condenatórias, não há transformação do patrimônio em dinheiro, mas simplesmente transferência do bem ao credor.

Em seguida, contudo, apesar da referência à classificação quinária, Cassio Scarpinella Bueno reconhece que, entre as tutelas condenatórias, executiva lato sensu e mandamental, a diferença "repousa muito mais nas técnicas de cada uma delas para a prestação da tutela jurisdicional do que em seu conteúdo ou [...] sua eficácia”, ${ }^{677}$ Cite-se, ainda, que o referido doutrinador propõe uma nova classificação das tutelas em transitivas e intransitivas, segundo a necessidade ou não de atividade jurisdicional complementar. ${ }^{678}$

Expostos tais entendimentos, deve-se constatar que, como bem advertiu José Roberto dos Santos Bedaque, “as classificações nada mais são do que tentativas de agrupar fenômenos segundo determinado ponto de vista, com o objetivo de compreendê-los”, e por isso "variam segundo o ângulo de análise". ${ }^{679}$ É necessário, por isso, adverte o autor, que se respeite a homogeneidade de critérios a serem adotados no desenvolvimento das classificações.

\footnotetext{
${ }^{676}$ BUENO, Cassio Scarpinella. Curso sistematizado de direito processual civil, v. 1, p. 355.

${ }^{677}$ Idem, ibidem, p. 361.

${ }^{678}$ Segundo a proposta do autor, seriam intransitivas as tutelas conhecidas como declaratória e constitutiva, que bastam por si sós, não dependendo da atividade jurisdicional complementar, ao contrário das transitivas, dentre as quais estariam inseridas as condenatórias, executivas e mandamentais, que necessitam dessa atividade jurisdicional para sua efetivação (BUENO, Cassio Scarpinella. Curso sistematizado de direito processual civil, v. 1, p. 369).

${ }^{679}$ BEDAQUE, José Roberto dos Santos. Efetividade do processo e técnica processual, p. 512.
} 
Nesse diapasão, sustenta José Roberto dos Santos Bedaque a validade da “concepção ternária” da tutela jurisdicional, e afirma que as denominadas sentenças executivas ou mandamentais “representam mera variação da forma como serão praticados os atos destinados à realização concreta do conteúdo do ato cognitivo: no mesmo processo ou mediante medidas de coerção”, ${ }^{680}$ e que, do ponto de vista prático, a classificação quinária não apresenta grande utilidade, ${ }^{681}$ pois leva em conta não a natureza da crise de direito material, mas a técnica de efetivação da sentença. ${ }^{682}$

Ou seja, não há diferença essencial entre o provimento condenatório e aquela sentença que se denomina de executiva lato sensu; é claro que pode haver alguma variação quanto à forma de efetivação do comando sentencial, mas o que não há é diversidade apoiada em critério que leve em conta o conteúdo ou a natureza jurídica do provimento jurisdicional, a justificar a criação de uma categoria autônoma de sentença. ${ }^{683}$

Apesar disso, a jurisprudência dos tribunais brasileiros aderiu à classificação quinária, mas não propriamente, ao que parece, por concordar com a criação dessa teoria que classifica em cinco espécies as tutelas jurisdicionais, e sim com o objetivo de identificar os provimentos que apresentam peculiaridades quanto ao seu cumprimento. ${ }^{64}$

${ }^{680}$ BEDAQUE, José Roberto dos Santos. Efetividade do processo e técnica processual, p. 533.

${ }^{681}$ Idem, ibidem, p. 519

682 Idem, p. 521.

${ }^{683}$ É condenatória a sentença que obriga o réu a entregar coisa, não importando, para essa classificação - que segue o critério baseado no conteúdo e no efeito do provimento -, se a sua efetivação se dará nos moldes tradicionais ou se é dotada daquela "força a mais" que pode o legislador conferir a qualquer provimento condenatório, tampouco é importante considerar a natureza da obrigação de entrega da coisa (dar ou restituir) para classificar como condenatória a sentença que a reconhece, não parecendo correto afirmar, em qualquer dessas hipóteses, que a sentença que condena o devedor a restituir bem do credor não dependa de execução. Nesse sentido: "independente de como se queira classificar a sentença que reconhece a obrigação de dar coisa (condenatória, executiva ou mandamental), a verdade é que “em todas essas hipóteses, o que existe é uma sentença que impõe ao demandado vencido um dever de prestação consistente em entrega de coisa -, impondo ou declarando atuável a sanção” (YARSHELL, Flávio Luiz. Reflexões em torno da execução para a entrega de coisa no direito brasileiro. In: CRUZ E TUCCI, José Rogério. Processo Civil: estudo em comemoração aos 20 anos de vigência do CPC, p. 129).

684 “Nas ações possessórias, a sentença de procedência tem eficácia executiva lato sensu, com execução mediante simples expedição e cumprimento de um mandado. Inocorrência, nas possessórias, da dicotomia ação de cognição e ação de execução. Com maior razão, se admitidos embargos em execução possessória de reintegração, o depósito da coisa será indispensável” (REsp 739/RJ, Min. Athos Carneiro, 4. Turma, DJ 21.08.1990). No mesmo sentido: REsp 10231/BA, 4. ${ }^{a}$ Turma, Min. Jorge Scartezzini, DJ 22.02.2005. 
Contudo, não entendemos necessária e pertinente a teoria quinária, e, ainda que se possa nela ver alguma utilidade, é certo que suas espécies não podem ser colocadas ao lado daquelas que tradicionalmente são apontadas pelo critério do conteúdo - declaratória, constitutiva e condenatória, pois, como já demonstrado, trata-se de classificações que levam em conta critérios diversos; para classificar as tutelas como declaratória, constitutiva ou condenatória, considera-se a natureza do provimento jurisdicional, ao passo que, para classificá-las como mandamentais ou executivas, toma em consideração as peculiaridades relativas à forma de cumprimento da sentença.

Conquanto se entenda pela utilidade da classificação segundo o critério observado nas teorias de Pontes de Miranda - o que, apesar das divergências, verifica-se na prática, tanto que a jurisprudência é assente em se referir às sentenças “executivas lato sensu” com o objetivo de identificar um peculiar modo de cumprimento -, seria preferível aderir à já mencionada proposta de classificação desenvolvida por Cassio Scarpinella Bueno, das tutelas transitivas e intransitivas, cujo critério de distinção é a forma de efetivação do provimento.

Não há mal algum em criar uma classificação que tenha por critério a forma de cumprimento do julgado; o mal está em misturar esse critério com o da natureza do provimento para tentar criar uma só classificação, como fez Pontes de Miranda ao se basear no critério técnica de efetivação da sentença para afirmar que não haveria nas ações possessórias tutela condenatória, espécie oriunda da classificação ternária, que leva em conta a natureza do provimento, “da crise de direito material”. ${ }^{685}$ Como bem registrou José Carlos Barbosa Moreira, “podemos classificar as sentenças de acordo com o conteúdo, ou de acordo com os efeitos”, mas o que "não podemos é passar, no meio do caminho, de um critério a outro". 686

\subsubsection{Classificação da tutela jurisdicional outorgada por meio das ações possessórias}

Pode o autor da demanda possessória cumular seu pedido de proteção da posse com o de “condenação em perdas e danos”, “cominação de penas para caso de nova

${ }^{685}$ BEDAQUE, José Roberto dos Santos. Efetividade do processo e técnica processual, p. 521.

${ }^{686}$ BARBOSA MOREIRA, José Carlos. Questões velhas e novas em matéria de classificação das sentenças. Revista Dialética de Direito Processual, n. 7, p. 38, out. 2003. 
turbação ou esbulho" e “desfazimento de construção ou plantação feita em detrimento de sua posse”; são estas as hipóteses previstas no artigo 921 do Código de Processo Civil.

Nada impede, ainda, que o autor cumule outros pedidos com o de proteção possessória, além daqueles previstos no artigo 921 do Código de Processo Civil, ${ }^{687}$ mas, neste caso, deverá, por força da norma do artigo 292, § 2. ${ }^{\circ}$, do mesmo Codex, renunciar ao procedimento especial. É comum essa ocorrência na hipótese de transferência da posse por meio de contrato, em que, verificada a inadimplência, o cedente, para obter a reintegração de posse, deverá requerer a resolução da avença, cumulando então tal pretensão com a da restituição da coisa - cúmulo incompatível com o procedimento especial das possessórias. $^{688}$

É possível, apesar da controvérsia já demonstrada anteriormente (item 4.9.1), a apresentação de pedido reconvencional pelo réu não apenas para requerer a proteção possessória e a indenização de acordo com a norma do artigo 922 do Código de Processo Civil, mas também em relação a eventual outra pretensão não incluída nesse dispositivo legal, por exemplo, a anulação de negócio jurídico em decorrência de dolo (art. 145, CC), a declaração de nulidade em razão de simulação (art. 167, CC), indenização e o direito de retenção por benfeitoria, o desfazimento de construção, entre outros.

Anotada, pois, a diversidade de pedidos que podem ser formulados nas ações possessórias, tanto pelo autor como pelo réu, seja no procedimento especial ou no

687 "Essas cumulações devem restringir-se, porém, a pretensões diretamente ligadas ao evento possessório, ou seja, a indenização há de referir-se a danos que o réu causou ao bem esbulhado ou turbado, a pena há de referir-se à reiteração do esbulho ou turbação que foi a causa da ação, e as construções e plantações a desfazer só podem ser aquelas introduzidas no imóvel onde ser deu a moléstia à posse do promovente" (THEODORO JÚNIOR, Humberto. Curso de direito processual civil, p. 135).

${ }^{688}$ FABRÍCIO, Adroaldo Furtado. Comentários ao Código de Processo Civil, v. 7, t. III. p. 439. Também nesse sentido: "Reintegração de posse. Compromisso de compra e venda de direitos possessórios. Posse 'tácita' com a entrega das chaves. Réu que permanece no imóvel, não reconhecendo o alegado negócio. Improcedência. Razoabilidade. Compromisso simulado eivado de vícios. Subsistência da decisão de improcedência da ação possessória. Reconvenção. Pedido de anulação de contrato e condenação da reconvinda em pagamento de perdas e danos. Contrato de honorários advocatícios celebrado em penitenciária. Simulação reconhecida. Anulação do negócio. Pedido reconvencional acolhido em parte. Manutenção da sentença. Recurso não provido” (Apelação 9108771-46.2005.8.26.0000, 18. ${ }^{\text {a Câmara do }}$ Tribunal de Justiça do Estado de São Paulo, Rel. Willian Marinho, DJ 14.09.2011). “Ação de nulidade de ato jurídico. decadência. Natureza constitutiva negativa da ação, que impõe o reconhecimento da decadência, quando inquinado o ato de simulação" (Apelação 0116180-76.2012.8.26.0100, 1. a Câmara de Direito Privado do Tribunal de Justiça do Estado de São Paulo, Rel. Alcides Leopoldo e Silva Junior, DJ 23.10.2012). 
ordinário - que deverá ser observado não apenas no caso de “força velha” (item 4.8.2), mas também quando o autor deduz pretensão diversa da possessória cuja cumulação não esteja autorizada pelo artigo 921 do Código de Processo Civil, muito embora seja defensável a aplicação de técnicas do procedimento especial compatíveis com o ordinário ${ }^{689}$-, tem-se que, por força do princípio da correlação, a tutela jurisdicional deverá corresponder à demanda do autor ou do réu, conforme determinam os artigos 128 e 460 do Código de Processo Civil. $^{690}$

As sentenças das ações possessórias deverão minimamente, portanto, em caso de procedência da demanda do autor ou do réu, outorgar a proteção da posse por meio da ação de reintegração com a restituição da coisa ao autor, ou pela manutenção com o afastamento da turbação e, ainda, pela via do interdito possessório, com a imposição de abstenção de atos pelo ofensor, podendo ainda tutelar outras pretensões. Cumpre, então, diante disso, averiguar como se classificam essas tutelas jurisdicionais.

Podem-se identificar nessas sentenças as tutelas declaratória e condenatória, e por vezes até mesmo a tutela constitutiva, como na hipótese de formulação de eventual pedido de anulação de negócio jurídico. Logo, é possível classificar perfeitamente as tutelas das ações possessórias por meio da tradicional teoria ternária.

No entanto, ao engendrar sua classificação segundo a carga preponderante de eficácia da sentença, Pontes de Miranda afirmou que a ação de manutenção de posse seria “ação de mandamento”, e não ação condenatória, pois, segundo o autor, na ação de

${ }^{689}$ Heitor Vitor Mendonça Sica sustenta que, ainda que escolhido o procedimento ordinário em razão da cumulação de pedidos para os quais correspondem procedimentos especiais diversos (art. 292, § 2. ${ }^{\circ}$, CPC), seria possível a utilização de técnicas do procedimento especial, desde que compatível com o ordinário (SICA, Heitor Vitor Mendonça. Reflexões em torno da teoria geral dos procedimentos especiais. Revista de Processo, ano 37, n. 208, p. 85, 2012). A partir disso, sendo possível a concessão de tutela antecipada no procedimento ordinário, por força da norma prevista no artigo 273 do Código de Processo Civil, pode-se admitir que o prevalecimento dos requisitos para a concessão de liminar no procedimento especial, vale dizer, a dispensa da demonstração da urgência ("risco de dano irreparável ou de difícil reparação"), pois, nessa hipótese, o procedimento ordinário foi imposto em razão da cumulação de pedidos, e não por ter decorrido ano e dia da ofensa. Dessa forma, sendo caso de ação de "força nova" pelo procedimento ordinário, deve-se admitir que a liminar seja concedida sem a demonstração do requisito da urgência, dado que a razão desse tratamento especial decorre justamente do decurso de menos de ano e dia do esbulho ou da turbação.

690 “Tal é a fórmula sistemática e global da regra de correlação entre o provimento jurisdicional e a demanda, a qual se apresenta com a dupla face de veto a excessos e de exigência de inteireza na oferta da tutela jurisdicional” (DINAMARCO, Cândido Rangel. Instituições de direito processual civil, p. 143). 
manutenção "há forte elemento declarativo, mas o elemento executivo é ínfimo: mantémse, apenas; não se precede a qualquer expropriação, em lato sensu não se invade a esfera jurídica do terceiro" ${ }^{691} \mathrm{E}$, na ação de reintegração, assevera o autor que “o elemento condenatório cresce, o de execução passa à frente do declaratório e do próprio elemento mandamental”, e conclui que "a sentença que reintegra executa”. ${ }^{692}$ Em resumo, concluiu Pontes de Miranda que, “classificadas as ações pela preponderância da eficácia, como devem ser, as ações de manutenção são mandamentais; e as ações de reintegração, executivas". 693

E, quanto ao interdito proibitório, entende o autor que se trata de ação mandamental, visto que a sentença nele proferia se assemelha ao provimento da ação de manutenção. ${ }^{694}$

Parte da doutrina brasileira até hoje adere à “teoria quinária das ações” para classificar as sentenças proferidas nas ações possessórias. Humberto Theodoro Júnior concorda com Pontes de Miranda e afirma que a ação de reintegração é ação executiva, e que a sentença que a acolhe só mediatamente tem eficácia condenatória e declarativa, mas “sua força processual é executiva”. Nesse passo, afirma o autor que o juiz “não condena, propriamente, o esbulhador a devolver a coisa, e sim ordena a imediata expedição de um mandado a ser cumprido coativamente pelos órgãos auxiliares do juízo contra o esbulhador e em favor do esbulhado". 695

Seguindo esse mesmo raciocínio tortuoso, de que não há condenação na ação de reintegração, mas sim “expedição de mandado a ser cumprido”, Ernane Fidelis dos Santos sustenta que não é possível classificar simplesmente como condenatória a sentença que decreta o despejo ou a que reintegra o possuidor na posse do bem, pois “o próprio

\footnotetext{
${ }^{691}$ PONTES DE MIRANDA. Tratado das ações, t. VI, p. 112.

${ }^{692}$ Idem, ibidem, p. 113.

${ }^{693}$ Idem, p. 113.

694 “A sentença, no interdito, mostra tanto elemento executivo quanto na própria sentença de manutenção, e de nenhum modo esse parece com a sentença (executiva) da ação de reintegração. Por outro lado, o veto do interdito proibitório, que é como o da ação de manutenção, possui, à sua base, menor dose de condenação que a da ação de manutenção e, $a$ fortiori, da ação de reintegração. O elemento mandamental prepondera como se passa com a própria sentença na ação de manutenção" (Tratado das ações, t. VI, p. 157).

${ }^{695}$ THEODORO JÚNIOR, Humberto. Curso de direito processual civil, v. 3, p. 133.
} 
comando, expedido pelo órgão jurisdicional, já é o cumprimento satisfativo da pretensão". 696

Também concorda com Pontes de Miranda a autora Cláudia Cimardi, ao aceitar que a sentença da ação de manutenção e do interdito proibitório deve ser classificada como mandamental, e que a da ação de reintegração, por carregar a eficácia da alteração da situação de fato, exige que o elemento preponderante seja o executório. ${ }^{697}$

No entanto, João Batista Monteiro, ${ }^{698}$ já na sua obra editada em 1987, teve a percepção de que devia ser revisto o entendimento de que as sentenças das ações possessórias, ditas executivas, não dependeriam de "instância executória”, eis que insuficiente a explicação de que esse provimento se efetiva mediante simples expedição de mandado de manutenção ou de reintegração.

O autor assevera, com absoluta razão, que as chamadas ações executivas "não prescindem de uma atividade especificamente dirigida à satisfação material da decisão”, e diferencia os dois momentos distintos nas ações possessórias, isto é, o primeiro, que se destina ao reconhecimento do direito e à imposição da restituição das partes ao status quo ante por meio da prolação da sentença, e o segundo, em que a atividade do juiz se dirige à satisfação material da decisão proferida, com o efetivo cumprimento do comando imposto na sentença. Em razão disso, João Batista Monteiro sustenta acertadamente que, “após o trânsito em julgado da sentença, segue-se, necessariamente, uma atividade, posterior, de natureza material, tendente ao cumprimento da decisão [...] é a execução propriamente dita, que assume características sui generis”. ${ }^{699}$

Seguimos o entendimento de João Batista Lopes, no sentido de identificar nas sentenças das ações possessórias, em relação à proteção da posse, a natureza condenatória, visto que por meio do pedido de reintegração de posse se alcança o provimento que

\footnotetext{
${ }^{696}$ SANTOS, Ernane Fidelis dos. Dos procedimentos especiais do Código de Processo Civil, v. 6, p. 117.

697 “A sentença na ação de reintegração traz como eficácia alteração da situação de fato, para recompor o estado anterior das coisas, com o que se exige que o elemento preponderante seja o executório, a fim de que possa ser alterada uma situação fática” (CIMARDI, Claudia Aparecida. Proteção processual da posse, p. 339).

${ }^{698}$ MONTEIRO, João Batista. Ação de reintegração de posse, p. 208-211.

${ }^{699}$ Idem, ibidem, p. 210.
} 
condena o réu a restituir a coisa esbulhada, e pela ação de manutenção ou pelo interdito se impõe obrigação de não fazer ao ofensor. Acompanha esse entendimento a doutrina italiana, o que se depreende da obra de Ettore Protetti, segundo quem a sentença, nas ações possessórias, trata de obrigação de fazer, não fazer ou de restituir. ${ }^{700}$

Pouco importa, portanto, para a identificação da natureza do provimento se o comando contido na sentença se cumpre imediatamente, sem intimação do vencido para cumprimento espontâneo, ou não.

Aliás, vale refletir, também, sobre a sentença da ação de despejo, que Pontes de Miranda chamava de “ação executiva pessoal”. ${ }^{701}$ Se julgada procedente a ação de despejo, o juiz determinará a expedição de mandado de despejo, que conterá o prazo de trinta dias para desocupação voluntária; é esta a redação do artigo 63 da Lei 8.245/1991. Inicialmente, fica evidente que essa sentença, assim como a da ação de reintegração da posse, contém condenação, destinada a obrigar o réu a restituir a coisa. Por conseguinte, verifica-se que o imediato cumprimento da sentença ou a intimação do vencido para cumprimento espontâneo do comando da sentença em nada altera a sua natureza.

Discorda-se, em razão disso, da afirmação de João Batista Lopes, de que, no provimento reintegratório, em relação ao vencido, "não existe uma obrigação a que possa ser condenado e que ele possa violar (como é da natureza das obrigações)", ${ }^{702}$ pois tal assertiva não explica satisfatoriamente a forma de efetivação das sentenças das ações possessórias, dado que a condenação pode não ser efetivada em razão da conduta do réu.

Note-se que, ao tratar da classificação da sentença da ação de reintegração de posse, a doutrina parece fazer alusão apenas ao esbulho de bem imóvel, que não apresenta qualquer dificuldade para a restituição forçada. Entretanto, para desconstruir essa teoria de inexistência de condenação, basta imaginar a reintegração de coisa móvel. Ou seja, como

\footnotetext{
700 "Infati, per esemplificazione, rileviamo che il contenuto dela sentenza in materia di azione di manutenzione concerce exclusivamente i beni immobili e tende a far cessar ela turbativa o la molestia. Spesso si tratta quinde di uńobbligazione di fare o di non fare, e pertanto si applicano le norme relative di cui agli artt. 612 e segg. Cod. Proc. Civ. Travolta si trata di condanna al rilascio, e in tal caso si applicano l enorme relative” (PROTETTÍ, Ettore. Le azioni possessorie, p. 701).

${ }^{701}$ PONTES DE MIRANDA. Tratado das ações, t. 7, p. 319.

${ }^{702}$ LOPES, João Batista. Ação de reintegração de posse, p. 211.
} 
seria possível conceber a inexistência de condenação que o vencido possa violar se, proferida a sentença de procedência na ação de reintegração, o réu simplesmente esconde o bem móvel objeto do litígio? Neste caso, a tutela seria efetivada com a simples expedição do mandado de reintegração? A resposta deve ser negativa, ao menos se concordarmos que “efetividade significa capacidade de produzir efeitos no plano material”. ${ }^{703}$ Seria necessária a realização de atividades - inúmeras, talvez -, de atos satisfativos, para encontrar o bem pretendido, ou, na impossibilidade, para satisfazer de algum outro modo o direito do autor.

O entendimento de que as sentenças das ações possessórias se executam sem a necessidade de atividades complementares poderia ser compreendido antigamente, quando existia a separação estanque entre os processos que se destinavam à cognição e aqueles em que se objetivava o cumprimento do julgado. Em verdade, porém, não se prescindia da atividade complementar, mas sim da instauração de novo processo. No entanto, com o denominado "processo sincrético”, que dispensa a instauração de um novo processo para execução do julgado, não há mais razão para distinguir a tutela condenatória daquela que a teoria quinária denominou “executiva”.

Deve-se levar em conta, ainda, que as sentenças das ações possessórias não têm como conteúdo apenas a proteção possessória, genericamente considerada, mas também outorgam tutelas correspondentes a todos aqueles pedidos que podem ser formulados tanto pelo autor como pelo réu, seja no procedimento especial ou no comum, conforme mencionado anteriormente, em atenção ao princípio da correlação.

Com isso, pode a sentença de procedência da ação de reintegração de posse anular negócio jurídico em razão de dolo ${ }^{704}$ (natureza constitutiva negativa), declarar o direito do autor em relação à posse (natureza declaratória) e, por consequência, condenar o réu a restituir a coisa ao autor (obrigação de entrega de coisa), a pagar indenização decorrente de

\footnotetext{
703 BEDAQUE, José Roberto dos Santos. Efetividade do processo e técnica processual, p. 518.

704 “Apelação cível. Anulação de compromisso de compra e venda c.c. reintegração de posse. Provas documentais e testemunhais corroboram o defeito no negócio jurídico. Lesão. Prescindível a má-fé. Caracterizada a premente necessidade e manifesta desproporção do valor da prestação oposta. Complementação do valor não requeria oportunamente. Conciliação possível a qualquer tempo. Benfeitorias. Necessidade de especificar estado anterior e atual, custo e mais-valia. Recurso desprovido" (TJSP, Apelação 0037874-62.2008.8.26.0576, 8. ${ }^{a}$ Câmara de Direito Privado, Rel. Ribeiro da Silva, DJ 26.09.2012).
} 
“perdas e danos” (obrigação de pagar quantia), a desfazer construção (obrigação de fazer) e a abster-se de praticar novo esbulho (obrigação de não fazer), podendo, ainda, condenar o autor a pagar indenização por benfeitorias ao réu, reconhecendo, com isso, o direito de retenção deste.

Ainda que se tratasse de sentença com conteúdo exclusivo de proteção da posse, seja na ação de reintegração, de manutenção ou no interdito proibitório, a classificação ternária é que permitiria identificar a natureza do provimento, sendo insuficiente o critério estabelecido pela "teoria quinária”, que poderia, quando muito, indicar o modo de cumprimento da sentença.

Assim, como já demonstrado, o cumprimento da sentença das ações possessórias não apresenta peculiaridade tão relevante em relação às demais tutelas condenatórias de entrega de coisa ou obrigação de fazer ou não fazer, a ponto de permitir a criação de subespécies, pois, em verdade, o que havia de diferente quando da criação da teoria de Pontes de Miranda era a necessidade da instauração de novo processo para executar o julgado - diferença extirpada do atual direito brasileiro -, e não a dispensa de realização de atividade complementar para efetivar a tutela jurisdicional.

\subsubsection{Cumprimento da sentença e defesa do vencido}

Depois da experiência com a tutela específica das obrigações de fazer e não fazer iniciada com a Lei 8.952/1994, que alterou o artigo 461 do Código de Processo Civil, o legislador estendeu esse tratamento processual para a tutela específica das obrigações de entrega de coisa, criando o artigo 461-A pela Lei 10.444/2002. ${ }^{705}$

Com esses dispositivos legais, e com a extensão do denominado processo sincrético à sentença que condena a pagar quantia (Lei 11.232/2005), a execução da sentença, ou "cumprimento de sentença", 706 não se faz mais por meio de processo

\footnotetext{
${ }^{705}$ As técnicas dos artigos 461 e 461-A do Código de Processo Civil iniciaram a tendência de superação da dualidade de processos (conhecimento e execução), e o reconhecimento de que a separação dos processos de conhecimento e de execução causava entraves indesejados, sendo, portanto, possível o seu afastamento, sem que, com isso, fosse relegada a segurança e o devido processo legal.

706 “Mas, bem pesadas as coisas, reduz-se com isso a muito pouco - estaríamos tentados a dizer: a nada - a diferença entre as figuras do ‘cumprimento’ e da ‘execução’ mencionadas no caput do art. 475-I. Em
} 
autônomo - à exceção da execução das sentenças penal, arbitral e estrangeira (art. 475-N, parágrafo único, CPC) e da execução contra a Fazenda Pública (art. 730, CPC) -, mas simplesmente por uma nova fase do mesmo processo, dispensando-se, portanto, a citação, que era uma das principais causas da lentidão da execução da sentença - não a única, mas uma das principais. ${ }^{707}$

Sendo assim, o cumprimento da sentença que condena ao pagamento de quantia será feito na forma dos artigos 475-J e seguintes do Código de Processo Civil, enquanto as sentenças que impõem obrigação de fazer e não fazer ou de entrega de coisa serão cumpridas de acordo com o regramento dos artigos 461 e 461-A do mesmo Codex.

Também as sentenças das ações possessórias se submetem à forma de cumprimento indicada nos referidos dispositivos legais, não havendo qualquer regra específica no procedimento especial dos artigos 920 a 932 do Código de Processo Civil que estabeleça procedimento diverso para a efetivação do julgado; pelo contrário, dispõe o artigo 931 que, após a contestação, “aplica-se, quanto ao mais, o procedimento ordinário”.

Na prática, o advento dessa nova sistemática não trouxe grandes reflexos práticos para a efetivação da tutela possessória quanto à aplicação do regramento do artigo 461 do Código de Processo Civil na fase de cumprimento da sentença da ação de manutenção de posse e do interdito proibitório, visto que a ordem de abstenção (obrigação de não fazer) já era imposta por meio da intimação do vencido, sem a necessidade de instauração de um processo de execução, com a imposição de multa para o caso de nova ofensa.

Entretanto, para o cumprimento da ordem de reintegração emanada da sentença, na hipótese de não ter havido concessão de liminar, o procedimento do artigo 461-A do

qualquer caso, tratar-se-á de sentença cuja efetivação, mediante atos materiais, se conterá por inteiro no mesmo processo em que se houver julgado. Nessa perspectiva, não admira que já se sustente em doutrina, pura e simplesmente, a sinonímia entre aqueles dois nomina iuris” (BARBOSA MOREIRA, José Carlos. Temas de direito processual. Nona série, p. 325).

${ }^{707}$ Ressalte-se que continuam dependendo do processo autônomo de execução a sentença estrangeira, a penal e a arbitral. 
Código de Processo Civil altera sobremaneira a forma como sempre foi concebida a execução dessa tutela jurisdicional, ${ }^{708}$ e adiante se esclarece o porquê dessa mudança.

A denominação de ação executiva lato sensu passou a ser atribuída às ações de reintegração de posse em virtude da sua peculiar forma de cumprimento, conforme já demonstramos no subitem anterior, a fim de identificar a possibilidade de imediata efetivação do julgado, sem a necessidade de instauração de processo autônomo de execução.

Em razão disso, tanto a doutrina como a jurisprudência firmaram o entendimento de que a sentença da ação de reintegração de posse não admite qualquer intervalo, nem mesmo para permitir ao vencido o cumprimento espontâneo da obrigação de restituição da coisa. Nessa ordem de ideias, mesmo os doutrinadores que não concordavam com a "teoria quinária das ações” sustentavam que não era necessária a intimação do executado porque não havia qualquer obrigação a ser cumprida, e que, por isso, o mandado deveria ser, desde logo, para que o oficial de justiça se deslocasse ao local onde a coisa se encontrava e, expulsando o vencido, colocasse o vencedor na situação fática em que se encontrava antes do esbulho. $^{709}$

Ocorre que, por força do artigo 461-A do Código de Processo Civil, o legislador previu momentos distintos para o cumprimento da tutela de entrega de coisa, de modo que, "inicialmente, o juiz deve conceder ao devedor um prazo para o cumprimento espontâneo da obrigação imposta” e, então, somente na hipótese de não ocorrer o cumprimento espontâneo é que "serão tomadas medidas de apoio, consistentes, a princípio, na busca e apreensão da coisa, se for móvel, ou na imissão na posse, se for imóvel”. ${ }^{710}$

${ }^{708}$ É certo que a norma do artigo 461-A do Código de Processo Civil abrange, pois, qualquer sentença que imponha obrigação de entrega de coisa - salvo disposição expressa em contrário -, assim como também é abrangente a regra do artigo 461 do mesmo Código em relação às obrigações de fazer e não fazer. Nesse sentido: "em função disso, as regras contidas no art. 461-A do CPC se prestam a regular o procedimento de efetivação das obrigações (sentido amplo) de dar coisa distinta de dinheiro. Abrange, com isso, as obrigações de restituir e as de dar propriamente ditas, bem assim as obrigações de dar coisa certa ou incerta, fungível ou infungível, móvel ou imóvel, desde que calcadas em título executivo judicial” (DIDIER JR., Fredie. Curso de direito processual civil, v. 5, p. 466).

${ }^{709}$ MONTEIRO, João Batista. Ação de reintegração de posse, p. 213.

${ }^{710}$ DIDIER JR., Fredie. Curso de direito processual civil, v. 5, p. 467-468. 
Apesar da crítica que se faz a tal procedimento, ${ }^{711}$ e considerando a possibilidade de abreviá-lo em situações de urgência - como no cumprimento da liminar de reintegração de posse em caso de risco de dano -, é certo que não mais pode subsistir o entendimento jurisprudencial $^{712}$ de que o cumprimento das sentenças das ações possessórios é imediato e não reclama a realização de atividades jurisdicionais, tampouco de que o executado não deve ser intimado a cumprir espontaneamente a ordem emanada do provimento, a exemplo do que também ocorre na sentença da ação de despejo por força do artigo 63 da Lei 8.245/1991.

Mais um motivo se soma, portanto, para demonstrar a imprecisão e inaplicabilidade do conceito de “ação executiva lato sensu”, tanto que o Superior Tribunal de Justiça já manifestou o entendimento de que devem ser equiparadas as "sentenças executivas lato sensu”,713 às tutelas concedidas com fundamento nos artigos 461 e 461-A do Código de Processo Civil, ou seja, agora somente não seriam executivas, pela teoria de Pontes de Miranda, as sentenças que condenam ao pagamento de quantia.

${ }^{711}$ Para Marcelo Abelha Rodrigues, o legislador perdeu uma ótima oportunidade de fazer com que o próprio provimento jurisdicional final fosse executivo, atribuindo-lhe a mesma força que normalmente se outorga aos provimentos interlocutórios de urgência, isto é, em vez de primeiro dirigir um comando para o réu para que este cumpra a obrigação, o próprio provimento já seria executivo, qual seja seria direcionado à imissão ou à busca e apreensão. Da maneira como fez o legislador, previu um momento para o atendimento do provimento que concedeu a tutela específica e logo após, se não cumprido, expedição de mandado executivo.

712 “O acórdão transitado em julgado certificou, entre outras, uma obrigação de fazer, consistente na desocupação do imóvel pela agravante e pela outra corré. Nessa linha, devolvidos os autos ao primeiro grau, a decisão ora agravada nada mais fez que especificar os meios mais adequados para a efetivação da tutela específica, optando pela execução direta da obrigação de fazer, em vez de uma ordem mandamental. Isso porque, em regra, a reintegração de posse ostenta características próprias de ação executiva lato sensu, prescindindo da colaboração do devedor-executado para a satisfação da prestação devida. Assim, na espécie, não há nenhum error in iudicando ou error in procedendo na escolha do magistrado a quo pela execução por sub-rogação” (TJSP, Agravo de Instrumento 990.10.202903-4, 7. ${ }^{\text {a }}$ Câmara de Direito Privado, Rel. Luiz Antonio Costa, DJ 30.06.2010). "Na esteira de culta doutrina (Serpa Lopes e Ovídio Baptista da Silva), as possessórias têm natureza executiva e devem ser processadas de plano, com a simples expedição do mandado, sendo desnecessária a citação do executado. Inaplicável, na espécie, o art. 603 do CPC. Precedentes (REsp 14.138/MS, Rel. Min. Sálvio de Figueiredo Teixeira e REsp 54.780/DF, Rel. Min. Carlos Alberto Menezes Direito). Ademais, sendo os objetos das ações demarcatória e possessória distintas, o resultado de uma não cria obstáculos na execução da outra, sendo desnecessário o aguardo da correta delimitação da área para que a reintegração de posse seja cumprida” (REsp 10231/BA, 4. ${ }^{a}$ Turma, Min. Jorge Scartezzini, DJ 22.02.2005).

713 “No atual regime do CPC, em se tratando de obrigações de prestação pessoal (fazer ou não fazer) ou de entrega de coisa, as sentenças correspondentes são executivas lato sensu, a significar que o seu cumprimento se opera na própria relação processual original, nos termos dos artigos 461 e 461-A do CPC” (REsp 1008311/RN, 1. a Turma, Min. Teori Albino Zavaski, DJ 05.04.2011). 
No tocante às demais obrigações que eventualmente podem ser impostas pela sentença das ações possessórias, relacionadas a outros pedidos que não o de proteção possessória, o cumprimento igualmente será efetivado nos moldes dos citados artigos 461, 461-A e 475-I e seguintes do Código de Processo Civil, com a possibilidade de impugnação somente no cumprimento de sentença que condena ao pagamento de quantia (art. 475-J, § 1. ${ }^{\circ}, \mathrm{CPC}$ ), segundo o texto da lei.

Não foi previsto expressamente no Código de Processo Civil o cabimento de defesa do devedor na fase de cumprimento das sentenças que impõem obrigação de fazer e não fazer ou de entrega de coisa (arts. 461 e 461-A, CPC), e essa constatação, aliada à expressa previsão de impugnação no procedimento de efetivação da tutela de obrigação de pagamento de quantia (arts. 475-J, § 1. ${ }^{\circ}$, e 475-L, CPC), pode causar a falsa impressão de que o legislador não quis viabilizar a defesa do devedor no procedimento da execução específica.

Apesar da eventual “inconveniência” da defesa do executado na fase de cumprimento da sentença que condena o réu a entregar coisa - inconveniência que se observa ao considerar o ideal de agilidade e efetividade da sistemática traçada para essa execução específica e imediata -, não se deve negar a oposição do devedor, o que violaria o contraditório e o devido processo legal.

Não obstante a divergência doutrinária, deve ser admitido que o devedor possa apresentar defesa quando fundada em fatos supervenientes ao trânsito em julgado ou defesa processual relacionada à própria fase de cumprimento de sentença, inclusive quanto às medidas de apoio, e que a única matéria relacionada à fase de conhecimento que o devedor pode arguir é a nulidade ou falta de citação, ou seja, deve-se admitir que a defesa seja fundada exatamente nas matérias relacionadas no artigo 475-L do Código de Processo Civil.

Muito embora se sustente na doutrina que as matérias de defesas poderão ser trazidas apenas em simples petição, e não por impugnação ao cumprimento, visto que seria incompatível essa via de defesa no sistema do cumprimento das sentenças que condenam a fazer, não fazer ou entregar coisa, há quem defenda inclusive o cabimento da impugnação: 
A circunstância das sentenças das ações possessórias dispensarem processo executivo autônomo tem gerado divergências doutrinárias a respeito da possibilidade da parte sucumbente se opor à fase executiva. [...] entendemos que o vencido tem direito de se opor à efetivação da sentença por meio dos embargos do devedor e dos embargos de retenção por benfeitorias. Não se pode negar ao vencido a possibilidade de invocar a tutela jurisdicional para evitar um excesso de execução, ou uma execução decorrente de processo eivado de vícios. ${ }^{714}$

Sustentando ser cabível a defesa do devedor, Flávio Luiz Yarshell apenas pondera que a matéria superveniente às denominadas sentenças mandamentais e executivas que imponham obrigação de entrega de coisa, quando relevantes para o deslinde da execução, “pode e deve ser alegada e conhecida na própria relação processual, desde que possa ser julgada de plano pelo juiz, sem a necessidade de proceder a dilação probatória, que não a simplesmente literal e pré-constituída”. 715

Nesse mesmo sentido, o Superior Tribunal de Justiça ${ }^{716}$ já manifestou o entendimento favorável ao cabimento de defesa do devedor na fase de cumprimento de sentença que impõe obrigação de fazer, não fazer ou entrega de coisa, mas igualmente admite a exceção por meio de "simples petição", e não pela via da “impugnação”. Em igual posicionamento, Humberto Theodoro Júnior afirma que, na ação possessória, com o advento do “processo unitário” (Lei 11.232/2005), a nulidade ou falta de citação pode ser

714 CIMARDI, Cláudia Aparecida. Proteção processual da posse, p. 339-340.

${ }^{715}$ YARSHELL, Flávio Luiz. Reflexões em torno da execução para a entrega de coisa no direito brasileiro. In: CRUZ E TUCCI, José Rogério. Processo Civil: estudo em comemoração aos 20 anos de vigência do CPC, p. 133 e 135.

716 “1. Os embargos do devedor constituem instrumento processual típico de oposição à execução forçada promovida por ação autônoma (CPC, art. 736 do CPC). Sendo assim, só cabem embargos de devedor nas ações de execução processadas na forma disciplinada no Livro II do Código de Processo. 2. No atual regime do CPC, em se tratando de obrigações de prestação pessoal (fazer ou não fazer) ou de entrega de coisa, as sentenças correspondentes são executivas lato sensu, a significar que o seu cumprimento se opera na própria relação processual original, nos termos dos artigos 461 e 461-A do CPC. Afasta-se, nesses casos, o cabimento de ação autônoma de execução, bem como, consequentemente, de oposição do devedor por ação de embargos. 3. Todavia, isso não significa que o sistema processual esteja negando ao executado o direito de se defender em face de atos executivos ilegítimos, o que importaria ofensa ao princípio constitucional da ampla defesa (CF, art. 5. $\left.{ }^{\circ}, \mathrm{LV}\right)$. Ao contrário de negar o direito de defesa, o atual sistema o facilita: ocorrendo impropriedades ou excessos na prática dos atos executivos previstos no artigo 461 do CPC, a defesa do devedor se fará por simples petição, no âmbito da própria relação processual em que for determinada a medida executiva, ou pela via recursal ordinária, se for o caso. 4. A matéria suscetível de invocação pelo devedor submetido ao cumprimento de sentença em obrigações de fazer, não fazer ou entregar coisa tem seus limites estabelecidos no art. 741 do CPC, cuja aplicação subsidiária é imposta pelo art. 644 do CPC” (REsp 654583/BA, 1. a Tuma, Rel. Min. Teori Albino Zavascki, j. 14.02.2006, DJ 06.03.2006, p. 177). 
arguida, no cumprimento de sentença, por meio de "simples impugnação por petição" para suscitar a exceção (art. 475-L). ${ }^{717}$

A princípio, pode-se imaginar que, do ponto de vista prático, não haveria diferença entre apresentar a defesa por meio de impugnação ou simples petição, mas, se considerarmos que a impugnação tem previsão expressa e que lhe é dispensado procedimento específico (arts. 475-L e 475-M, CPC), sobretudo no tocante às matérias que podem ser arguidas pelo devedor e à possibilidade de concessão de efeito suspensivo, essa diferença existe. Todavia, nada impede que o procedimento previsto para a impugnação do cumprimento de sentença que impõe obrigação de pagar quantia possa ser observado na oposição do devedor à execução específica (arts. 461 e 461-A, CPC) e, se admitida tal interpretação, então realmente não haveria diferença do ponto de vista prático entre apresentar a defesa por meio de “simples petição” ou rotulá-la como “impugnação”.

Assim, reconhecido o direito de defesa do devedor, resta enfrentar a polêmica sobre a possibilidade ou não de concessão de efeito suspensivo à defesa manifestada por simples petição pelo devedor de obrigação de entrega de coisa reconhecida em sentença condenatória - o que inclui as denominadas executivas e mandamentais.

De acordo com Fredie Didier, ${ }^{718}$ a defesa apresentada nessas condições, porque inadmissível a impugnação no procedimento dos artigos 461 e 461-A do Código de Processo Civil, deve seguir "o trilho do que ocorre com a impugnação à execução das decisões que impõem obrigação de pagar quantia [...] não suspende o curso da fase de execução, admitindo-se, porém, que o magistrado atribua esse efeito”. Por seu turno, para Dinamarco, ${ }^{719}$ as defesas de mérito apresentadas pelo devedor mediante simples petição não deverão ensejar a suspensão do processo executivo.

Entendemos que a solução apontada pelo segundo autor, de não suspender a realização das atividades que compõem a fase executiva do processo quando não cabível a impugnação, deve ser adotada como regra, mas não de forma absoluta, pois pode haver

\footnotetext{
717 THEODORO JÚNIOR, Humberto. Curso de direito processual civil, v. 3, p. 135.

${ }^{718}$ DIDIER JR., Fredie; CUNHA, Leonardo José Carneiro da; OLIVEIRA, Rafael. Curso de direito processual civil, v. 5, p. 465.

${ }^{719}$ DINAMARCO, Cândido Rangel. Instituições de direito processual civil, v. 4, p. 530.
} 
casos em que a constatação da procedência ou não da defesa do devedor não possa ser conhecida de plano - e nem por isso deve ser repelida. Se o devedor alega que o vencedor da ação de reintegração de posse pretende obter área maior do que aquela que fora objeto da demanda e sobre a qual recai seu direito de restituição, e se presente o risco de dano, nada impede que o juiz suspenda o ato de efetivação da sentença (mandado de reintegração) até apurar a verdade, ${ }^{720}$ o que seria perfeitamente possível com fundamento no poder geral de cautela (art. 798, CPC).

Por fim, quanto ao cabimento de embargos de retenção na fase de cumprimento de sentença, já é pacífica na jurisprudência ${ }^{721}$ e na doutrina ${ }^{722}$ a sua inadmissibilidade, uma vez que o artigo 744 do Código de Processo Civil, que regulava a figura autônoma dos embargos de retenção, ${ }^{723}$ foi revogado, tendo a Lei 11.382/2006 integrado o direito de retenção ao rol dos fundamentos para os embargos do executado, conforme se depreende do artigo 745, inciso IV, do Código de Processo Civil, que faz referência apenas à execução de título extrajudicial.

720 “Exemplificativamente, se tiver ocorrido novação superveniente à sentença, porque os litigantes ajustaram mais certo tempo de permanência do bem em poder do demandado, ou ainda se o demandante pretender o desapossamento de coisa diversa daquela fixada na sentença, o executado pode e deve embora se expondo à constrição de sua esfera jurídica - articular tais ocorrências, opondo-se pela via definida e regulamentada dos embargos” (YARSHELL, Flávio Luiz. Reflexões em torno da execução para a entrega de coisa no direito brasileiro. In: CRUZ E TUCCI, José Rogério. Processo Civil: estudo em comemoração aos 20 anos de vigência do CPC, p. 133).

721 “Embora a exposição de tal matéria continue possível em sede de contestação ou em embargos à execução (Código de Processo Civil, artigo 745, inciso IV), o exercício do direito de retenção é inadmissível por meio de embargos opostos contra título judicial (no caso dos autos, contra a sentença homologatória da transação celebrada entre as partes). Inadequada, assim, a via processual eleita pelos embargantes, de modo que era mesmo de rigor a extinção do processo sem resolução do mérito” (TJSP, Apelação 0016026-95.2009.8.26.0604, Rel. Carlos Henrique Miguel Trevisan, j. 16.08.2012, 4. ${ }^{\text {a }}$ Câmara de Direito Privado, publ. 21.08.2012).

722 “A manutenção do processo de execução autônomo apenas para os casos de execução fundada em título executivo extrajudicial suprimiu também a figura dos embargos de retenção por benfeitorias fundados em título judicial” (RODRIGUES, Marcelo Abelha. Manual de execução civil, p. 271-272).

723 “Os embargos de retenção, portanto, não substituíam os embargos à execução nem vice-versa. Cada qual tinha sua finalidade, sendo certo que a matéria referente aos arts. 475-L e 745 do CPC era totalmente estranha aos embargos de retenção" (CAMPOS, Gledson Marques de. Ação autônoma de execução para a entrega de coisa. In: CIANCI, Mirna; QUARTIERI, Rita (Coord.). Temas atuais da execução civil em homenagem ao Professor Donaldo Armelin, p. 275). 
Não se olvida, entretanto, que o direito à indenização por benfeitoria e o respectivo direito de retenção, ${ }^{724}$ previstos no artigo 1.219 do Código Civil, ${ }^{725}$ tenham ficado desamparados. A jurisprudência continua admitindo a apresentação desses pedidos pelo réu em contestação, o que, mesmo antes da revogação do artigo 744 do Código Civil, já era requisito para admissibilidade dos embargos de retenção na execução de título judicial.

Como demonstrado anteriormente (item 4.9.1), apesar da alteração legislativa que tornou incabível a via dos embargos de retenção no cumprimento de sentença, o direito de retenção por benfeitorias úteis e necessárias deverá ser reclamado pelo possuidor de boa-fé em contestação - ou por meio de reconvenção, na forma da lei -, a fim de que seja declarado na sentença que julga procedente o pedido de reintegração de posse. Pode ainda ocorrer de ser realizada benfeitoria após a apresentação da contestação, mas, por se tratar de fato novo (art. 303, I, CPC), poderá o juiz reconhecer o direito de indenização e de retenção em sentença.

Portanto, sequer seria necessário o manejo dos embargos de retenção, visto que a própria sentença já contém condição à exequibilidade da ordem de reintegração de posse. Ou seja, se a sentença reconheceu o direito de retenção do réu, haverá condição a ser cumprida antes da execução, ${ }^{726}$ e por isso não poderá ser efetivada a sentença no tocante à obrigação de restituição da coisa enquanto não for paga pelo autor da demanda possessória a quantia arbitrada a título de indenização por benfeitoria.

De qualquer forma, se a não observação dessa condição viabilizar o início do cumprimento da ordem de reintegração de posse, poderá o vencido arguir a inexequibilidade do título por meio de simples petição e, caso não acolhida essa exceção,

${ }^{724} \mathrm{O}$ possuidor de boa-fé tem direito à indenização por benfeitorias úteis e necessárias, assim como pelas voluptuárias, mas apenas em relação àquelas existe o direito de retenção como forma de garantir o ressarcimento. Já o possuidor de má-fé, assim definido aquele que conhece o vício da sua posse, tem direito à indenização apenas pelas benfeitorias necessárias, mas não lhe assiste o direito de retenção.

725 “Art. 1.219. O possuidor de boa-fé tem direito à indenização das benfeitorias necessárias e úteis, bem como, quanto às voluptuárias, se não lhe forem pagas, a levantá-las, quando o puder sem detrimento da coisa, e poderá exercer o direito de retenção pelo valor das benfeitorias necessárias e úteis.”

${ }^{726}$ Nesse sentido: THEODORO JÚNIOR, Humberto. Processo de execução e cumprimento da sentença, p. 593. DINAMARCO, Cândido Rangel. Instituições de Direito Processual Civil, v. 4, p. 254. 
terá à sua disposição o recurso de agravo de instrumento (art. 522, CPC) para coibir o cumprimento arbitrário da sentença.

Considerando-se a hipótese de não ter sido alegado o direito de retenção na contestação, e admitindo não ser possível a oposição de embargos de retenção na fase de cumprimento de sentença que impõe obrigação de entrega de coisa, cogita-se da possibilidade de ajuizamento de “ação autônoma” pelo possuidor de boa-fé com o objetivo de ver reconhecido o seu direito à indenização. No entanto, nessa hipótese haveria ofensa à coisa julgada, por força da norma do artigo 474 do Código de Processo Civil, pelo que deveria ser extinta a ação com fundamento no artigo 267, inciso V, do Código de Processo Civil. $^{727}$

727 "Direito civil e processo civil. Retenção por benfeitorias. Exercício mediante ação direta. Direito que não fora exercido quando da contestação, no processo de conhecimento. Sentenças com acentuada carga executiva. Necessidade. 1. A jurisprudência desta Corte tem se firmado no sentido de que a pretensão ao exercício do direito de retenção por benfeitorias tem de ser exercida no momento da contestação de ação de cunho possessório, sob pena de preclusão. 2. Na hipótese de ação declaratória de invalidade de compromisso de compra e venda, com pedido de imediata restituição do imóvel, o direito de retenção deve ser exercido na contestação por força da elevada carga executiva contida nessa ação. O pedido de restituição somente pode ser objeto de cumprimento forçado pela forma estabelecida no art. 461-A do CPC, que não mais prevê a possibilidade de discussão, na fase executiva, do direito de retenção. 3 . Esse entendimento, válido para o fim de impedir a apresentação de embargos de retenção, deve ser invocado também para impedir a propositura de uma ação autônoma de retenção, com pedido de antecipação de tutela. O mesmo resultado não pode ser vedado quando perseguido por uma via processual, e aceito por outra via. 4. Recurso especial conhecido e improvido" (REsp 278094/SP, 3. ${ }^{\mathrm{a}}$ Turma, Min. Nancy Andrighi, DJ 16.08.2012). 
5

\section{OUTROS REMÉDIOS DE PROTEÇÃO \\ PROCESSUAL DA POSSE}

\subsection{Definição}

Como afirmado anteriormente, a tutela jurisdicional da posse pode ser alcançada por meio das “ações possessórias típicas”, tratadas no “Capítulo 4”, e também pelos denominados "remédios processuais de proteção da posse", ${ }^{728}$ assim compreendidos os meios judiciais que não têm na posse a única possibilidade de fundamento jurídico, tampouco a sua proteção como objeto único e exclusivo, ou seja, nesses tais remédios processuais é possível que se tenha como fundamento a posse e como objetivo indireto, a sua proteção, mas é também possível que o fundamento recaia no direito de propriedade, e que este seja o objeto da tutela jurisdicional.

Embora se as nominem de “ações possessórias lato sensu”, ou “ações possessórias atípicas”, é preferível a denominação “remédios processuais de proteção da posse”, porquanto nessa categoria deverão ser inseridas também aquelas ações às quais se atribui o caráter petitório, em contraposição ao possessório. Diz-se petitória a ação fundada no direito de propriedade ou em outro direito sobre a coisa, como ocorre na ação de imissão

728 “De fato, conforme prestigiosa lição doutrinária, remédio é termo ontológico que se aplica à ação de qualquer natureza quando, para consecução de um fim, há impedimento a remover. Deve ele ter eficácia, atendendo a condições que ‘disponham a virtude da causa' e 'apliquem a agir'. Nessa medida, portanto, a ação poderia ser reputada um 'remédio jurídico’, quando entendida em uma acepção objetiva. O termo 'remédio jurídico processual' oscila, na doutrina, entre a ação e o processo. Esse fato, embora prejudique juízos de certeza que devem estar associados ao exame de natureza científica, é compreensível diante de que, embora os vocábulos traduzam fenômenos distintos, relacionam-se intimamente, mesmo em face de diferentes concepções doutrinárias acerca de um e outro: sob a ótica da tutela dos direitos, é realmente difícil isolar os fenômenos da estimulação da atividade jurisdicional, de um lado, e do respectivo desenvolvimento, de outro lado. Em qualquer uma dessas perspectivas, parece certo que 'remédio' está atrelado à tutela (com significado de resultado), no sentido de que estabelece meios para que ela seja atingida” (YARSHELL, Flávio Luiz. Tutela jurisdicional, p. 178). 
de posse e na reivindicatória, enquanto se atribui o caráter possessório aos interditos, que se fundamentam única e exclusivamente no ius possessionis. ${ }^{729}$

Em razão disso, Joel Dias Figueira Jr. afirma que não existem outras ações de natureza possessória além daquelas três previstas no procedimento especial do Código de Processo Civil, que têm como causa petendi exclusivamente a posse. ${ }^{730}$ Segundo o mesmo autor, "as ações possessórias se caracterizam por pedirem a posse com fundamento no fato da posse”, o que não acontece na ação de imissão de posse, que estava inserida no procedimento especial das ações possessórias do Código de Processo Civil de 1939, mas deixou de ser assim regulada pelo Código de 1973.

É correto o entendimento de que todos os outros remédios processuais citados pela doutrina como vias de proteção da posse, que não o interdito proibitório e as ações de manutenção e de reintegração de posse - ações possessórias que serão denominadas “típicas” por estarem tipificadas na lei -, não têm caráter possessório, porquanto não se fundamentam exclusivamente na posse. Não obstante, não se reprova em absoluto a denominação desses remédios jurídicos de “ações possessórias lato sensu”, ou “atípicas”, 731 visto que algumas dessas medidas também podem ter como fundamento a posse, à exceção da ação de reivindicação e de imissão de posse, ${ }^{732}$ que, segundo Figueira Jr., embora não se trate de remédio puramente interdital, têm caráter misto (petitório e possessório). ${ }^{733}$

729 “[...] quando a demanda versar sobre o domínio e não sobre a posse da coisa, ela terá natureza petitória (juízo petitório), não mantendo relação com as ações ditas possessórias - estas, sim, fundadas no direito à posse” (MARCATO, Antônio Carlos. Procedimentos especiais, p. 140).

${ }^{730}$ FIGUEIRA JR., Joel Dias. Liminares nas ações possessórias, p. 76.

731 “Assim, podemos classificar tais ações em possessórias stricto sensu, as quais têm como exclusivo fundamento a posse, e comportam única e tão somente - como pedido principal - a defesa da posse; e possessórias lato sensu, as quais, eventualmente, podem fundar-se na posse, mas não necessariamente" (CIMARDI, Cláudia Aparecida. Proteção processual da posse, p. 73).

${ }^{732}$ Haverá, contudo, certa restrição em relação ao emprego da expressão "ações possessórias lato sensu” ou “atípicas" em relação às ações de reivindicação e de imissão de posse, pois, por serem classificadas como ações petitórias, podem ser incompatíveis com a designação de ação possessória. No entanto, deixando de lado essa questão meramente terminológica, o que importa considerar é que tanto as ações de caráter possessório quanto aquelas denominadas petitórias podem ser inseridas em uma mesma categoria, a dos remédios processuais que têm como objetivo a proteção da posse.

733 FIGUEIRA JR., Joel Dias. Liminares nas ações possessórias, p. 81. 
Enfim, tais são os principais "remédios processuais de proteção da posse” mencionados pela doutrina que merecem considerações: ação de nunciação de obra nova, “ação de dano infecto”, “ação demolitória”, embargos de terceiro, “imissão de posse” e “ação reivindicatória” - cuja diferença será demonstrada adiante. Além desses remédios costumeiramente citados pela doutrina, entendemos ser oportuno acrescer nesse rol a ação de despejo, visto que, não fossem os procedimentos especiais instituídos pela Lei 8.245/1991 e pelo Decreto 59.566/1966, a pretensão de restituição do imóvel pelo locador ou pelo arrendador seria manifestada por meio de pedido de reintegração de posse, decorrente de extinção do respectivo contrato.

Não serão abordados nesse momento os embargos de retenção como remédio de proteção da posse, visto que não se trata mais de ação autônoma, ante a revogação do artigo 744 do Código de Processo Civil pela Lei 10.444/2002. A pretensão de retenção por benfeitoria, pelo atual sistema (art. 745, CPC), deve ser manifestada por meio dos embargos à execução para os casos de título extrajudicial, ou em contestação, motivo pelo qual será debatida a polêmica sobre a persistência de seu cabimento no tópico que adiante tratará do cumprimento da sentença.

\subsection{Ação de nunciação de obra nova, “ação demolitória” e “ação de dano infecto”}

Em razão da semelhança da causae petendi dos três remédios processuais em questão, qual seja o risco representado pelo prédio vizinho ao imóvel do autor - seja decorrente de obra nova, concluída ou em ruína -, reúnem-se nesse mesmo subitem as considerações sobre seus aspectos gerais, o que permitirá demonstrar os pontos em comum e as diferenças existentes entre as três medidas.

É regulamentada nos artigos 934 a 940 do Código de Processo Civil, em procedimento especial, a ação de nunciação de obra nova, que compete ao proprietário ou possuidor, a fim de impedir que a edificação de obra nova em imóvel vizinho lhe prejudique o prédio, servidões ou fins a que é destinado (inciso I, art. 934, CPC), assim como ao condômino, para impedir que o coproprietário execute alguma obra com prejuízo ou alteração da coisa comum (inciso II), e ao Município, de modo a impedir que o particular construa em contravenção da lei, do regulamento ou de postura (inciso III). 
Extrai-se do texto do Código que são legitimados o proprietário, o possuidor, o condômino e o Município para a propositura da referida ação, que tem como causa de pedir o prejuízo ao imóvel do autor decorrente de uma obra iniciada, porém não finalizada, em prédio vizinho, e como objeto a pretensão de impedir, em um primeiro momento, o prosseguimento da obra e, por fim, o retorno ao estado anterior, que poderá implicar a demolição, reconstrução, restauração, enfim, o que for necessário para o retorno ao status quo ante. $^{734}$

Deve-se entender por obra nova não apenas a edificação, mas qualquer alteração do imóvel vizinho que acarrete prejuízo ao imóvel do autor. Segundo Antônio Carlos Marcato, entende-se por obra, além da edificação, “remodelação, reforma, escavações, terraplanagem, extração de minérios, colheita, corte de madeiras, enfim, qualquer atividade que coloque em risco o direito de propriedade sobre os imóveis vizinhos ou contíguos”. ${ }^{73}$

Na opinião de Nelson Nery Junior, a ação de nunciação de obra nova "pode eventualmente ter fundamento na posse, mas, na verdade, o que se quer proteger é a propriedade». ${ }^{736}$ No mesmo sentido, Tito Fulgêncio sustenta que a pretensão de embargar a obra não tem como fundamento a posse, nem como objetivo a sua proteção, e que o possuidor somente é legitimado a propor esta ação porque “a obra nova em imóvel vizinho pode prejudicar o prédio em mãos do possuidor”. ${ }^{737}$

Nota-se, portanto, que a nunciação de obra nova não tem como objeto a defesa da posse, mas sim a proteção do imóvel sobre o qual se exerce direito de posse ou de propriedade. Conforme ressalvado por Cláudia Cimardi, embora tenha o possuidor legitimação ativa para a referida ação, “tal circunstância não implica em que essa ação

\footnotetext{
734 “Caberá ao réu restabelecer a situação fática anterior e o juiz poderá impor multa diária para forçá-lo ao cumprimento da sentença” (MEDINA, José Miguel Garcia; ARAÚJO, Fábio Caldas de; GAJARDONI, Fernando da Fonseca. Procedimentos cautelares e especiais, p. 292).

735 MARCATO, Antônio Carlos. Procedimentos especiais, p. 156.

${ }^{736}$ NERY JUNIOR, Nelson; NERY, Rosa Maria de Andrade. Código de Processo Civil comentado, p. 1401.

${ }^{737}$ FULGÊNCIO, Tito. Da posse e das ações possessórias, p. 274.
} 
tenha natureza possessória”, 738 porquanto não tem como fundamento a posse, e não se busca, por meio desse remédio, a sua proteção. ${ }^{739}$

É certo, porém, que o provimento da nunciação de obra nova acarreta, por consequência prática e pela via transversa, a proteção da posse, tanto do possuidor quanto do proprietário, por impedir que os prejuízos da obra em imóvel vizinho impedissem o pleno exercício da posse sobre toda a área ameaçada. Contudo - repita-se -, não é o objetivo da ação de nunciação de obra nova a proteção da posse, o que, entretanto, pode eventualmente pode ocorrer. ${ }^{740}$

A ação de nunciação de obra nova não será cabível, porém, quando estiver concluída a obra, podendo o legitimado se valer, para obrigar o vizinho a desfazer da obra, da denominada “ação demolitória”, que será fundamentada nos artigos 1.280 e 1.312 do Código Civil, que tratam, respectivamente, do imóvel que se encontra em ruína ou em desacordo com as determinações da lei civil.

O legislador não regulamentou, para esse remédio processual, procedimento especial, pelo que deverá o processo se desenrolar pelo procedimento ordinário.

Em relação ao ponto que interessa para o presente trabalho, qual seja a demonstração de qual relação esses remédios têm com a proteção da posse, pode-se concluir que, assim como na ação de nunciação de obra nova, o objetivo da "ação demolitória” não é diretamente a proteção da posse, mas reconhece-se que "pode o

\footnotetext{
${ }^{738}$ CIMARDI, Cláudia Aparecida. Proteção processual da posse, p. 81.

739 “Vizinhança ação de nunciação de obra nova indeferimento da inicial (artigo 295, III e V, do CPC). Ação de nunciação de obra nova visando defender a propriedade e posse de servidão de passagem. Existência de ação possessória a respeito, na qual foi concedida liminar em favor daquela contra a qual a autora se volta. Inadequação processual e procedimental. Sentença confirmada. Apelo improvido” (TJSP, Apelação 0008888-20.2011.8.26.0568, Rel. Mendes Gomes, 35. ${ }^{a}$ Câmara de Direito Privado, j. 13.08.2012, publ. 14.08.2012).

740 "Parece preferível, no entanto, dizer que a nunciação de obra nova não visa, direta e exclusivamente, à defesa da posse. Se, em certos casos, confere a proteção - uma vez que por ela se defende o uso e o gozo da coisa em toda a sua potencialidade, ameaçada pela obra nova - essa proteção não tem caráter exclusivo; é atingida por via indireta” (MONTEIRO, João Batista. Ação de reintegração de posse, p. 56).
} 
possuidor através dela obter um pronunciamento judicial que, indiretamente, defenda sua posse". ${ }^{741}$

Quando houver risco de ruína de prédio, o proprietário ou possuidor do imóvel vizinho poderá pedir que o seu dono seja obrigado a demoli-lo, pretensão que se fundamenta no artigo 1.280 do Código Civil $^{742}$ e que pode ser manifestada por meio da denominada "ação de dano infecto”. Esse remédio processual apenas tem relação com a posse por conta da legitimação do possuidor para proteger seu imóvel contra o risco representado pelo prédio vizinho em ruínas, igualmente ao que se passa na ação de nunciação de obra nova.

Pelas mesmas razões expostas nos tópicos anteriores, portanto, não se trata de ação possessória propriamente dita, tampouco se tem como fundamento ou objeto a posse e sua proteção, respectivamente, porquanto aqui também o que se protege não é a posse, mas sim o imóvel possuído, muito embora seja possível que, em determinadas situações, a tutela jurisdicional prestada por meio desse remédio processual implique, por via oblíqua, a proteção da posse.

O interesse que a lei visa a tutelar, afirma Francisco Eduardo Loureiro, "não se restringe ao desabamento da construção, mas se estende a hipóteses análogas, que coloquem em risco a incolumidade ou o patrimônio dos vizinhos, como incêndio, inundação ou desmoronamento", 743 acontecimentos que acarretariam, evidentemente, restrição ou privação da posse o autor da ação, o que demonstra a possibilidade, ainda que casual, de indireta proteção da posse por meio desse remédio processual.

\subsection{Embargos de terceiro}

Dispõe o artigo 1.046 do Código de Processo Civil que “quem, não sendo parte no processo, sofrer turbação ou esbulho na posse de seus bens por ato de apreensão judicial,

\footnotetext{
${ }^{741}$ CIMARDI, Cláudia Aparecida. Proteção processual da posse, p. 85.

742 “Art. 1.280. O proprietário ou o possuidor tem direito a exigir do dono do prédio vizinho a demolição, ou a reparação deste, quando ameace ruína, bem como que lhe preste caução pelo dano iminente.”

${ }^{743}$ LOUREIRO, Francisco Eduardo. In: PELUSO, Cezar (Coord.). Código Civil comentado, p. 1.294.
} 
em casos como o de penhora, depósito, arresto, sequestro, alienação judicial, arrecadação, arrolamento, inventário, partilha, poderá requerer lhe sejam manutenidos ou restituídos por meio de embargos”.

Ou seja, esse remédio jurídico busca assegurar aquele que, não sendo parte do processo, sofre turbação ou esbulho na posse de seus bens em decorrência de ato judicial dele emanado; terá legitimidade para ajuizar os embargos de terceiro, portanto, quem não é parte do processo. $^{744}$

Em relação à ordem de constrição, esta pode ser emanada em processo de conhecimento, execução, cautelar e, inclusive, de processo penal, desde que se trate de ordem judicial, ficando excluídos, portanto, conforme ressaltado por João Paulo Hecker da Silva, os atos extrajudiciais em que possa haver turbação ou esbulho na posse dos bens de terceiro, tais como apreensão de bens por autoridade policial ou em processo administrativo". ${ }^{745}$

Por decorrência disso, note-se que os embargos de terceiro podem ser opostos inclusive contra decisão proferida em ação possessória, conforme precedente do Superior Tribunal de Justiça. ${ }^{746}$

Poderão os embargos de terceiro ser repressivos ou preventivos, sendo cabíveis, assim, tanto quando já ocorrida a constrição judicial, como também na hipótese em que se pretende evitá-la, sendo suficiente, para tanto, a ameaça real e concreta, ${ }^{747}$ e "prescindível a realização concreta do ato judicial”. ${ }^{748}$

\footnotetext{
744 "Embargos de terceiro. Título executivo judicial. Interposição de embargos de terceiro pela própria coexecutada. Impossibilidade. Ilegitimidade ativa da embargante. Extinção corretamente decretada. Sentença confirmada. Recurso não provido" (TJSP, Apelação 9207202-76.2009.8.26.0000, Rel. Elcio Trujillo, 10. ${ }^{\text {a }}$ Câmara de Direito Privado, j. 14.02.2012, publ. 14.02.2012).

${ }^{745}$ SILVA, João Paulo Hecker da. Embargos de terceiro, p. 47.

746 “Cabem embargos de terceiro propostos por quem é atingido na sua posse pelo cumprimento de mandado expedido em ação possessória para a qual o embargante não foi citado. Art. 1.046 do CPC” (REsp 182.189/SP, Rel. Min. Ruy Rosado, DJ 29.10.1998).

${ }^{747}$ ARRUDA ALVIM; ASSIS, Araken de; ALVIM, Eduardo Arruda. Comentários ao Código de Processo Civil, p. 2008.

${ }^{748}$ SILVA, João Paulo Hecker da. Embargos de terceiro, p. 50.
} 
Diversamente do que ocorre nos demais remédios processuais vistos anteriormente, os embargos de terceiro têm por objeto a proteção da posse, seja do ius possessionis ou do ius possidendi. É certo, porém, que, com os embargos de terceiro, busca-se o "desfazimento de ato de constrição efetivado por autoridade jurisdicional e, por conseguinte, a eliminação da turbação e do esbulho advindos da concretização da ordem judicial”; 749 almeja-se, por fim, então, o "provimento jurisdicional que proteja quer a propriedade, quer a posse do embargante, podendo, por isso mesmo, fundamentar-se tanto no direito real quanto pessoal”. ${ }^{750}$ Darcy Bessone sustenta, no entanto, que, nos embargos de terceiro, "o que mais importa é que a impugnação tem por alvo o ato público e jurisdicional da apreensão de bens, não o ato privado de assunção da posse”. ${ }^{751}$

O fundamento da demanda poderá ser tanto a posse como a propriedade, ${ }^{752}$ razão pela qual não se inserem os embargos de terceiro no rol das ações possessórias strito sensu, devendo ser igualmente classificados como remédio processual de tutela da posse. Admitese, inclusive, a oposição de embargos de terceiro pelo proprietário não possuidor, conforme já admitido pela doutrina ${ }^{753}$ e pela jurisprudência. ${ }^{754}$

J.M. de Carvalho Santos afirma que os embargos de terceiro, na sua essência, não passam de um remédio meramente possessório, que visa a "garantir o direito do possuidor ser mantido na posse, em caso de turbação”. ${ }^{755}$ Seguindo o mesmo entendimento, Luiz Guilherme Marinoni sustenta que, nos embargos de terceiro, se apresenta uma pretensão possessória ou dominial específica, voltada ao afastamento da violação da posse causada por decisão judicial. ${ }^{756}$

\footnotetext{
${ }^{749}$ CIMARDI, Cláudia Aparecida. Proteção processual da posse, p. 96.

${ }^{750}$ MARCATO, Antônio Carlos. Procedimentos especiais, p. 248.

${ }^{751}$ BESSONE, Darcy. Da posse, p. 153.

${ }^{752}$ FULGÊNCIO, Tito. Da posse e das ações possessórias, p. 276.

753 "Ocorre que a ação de embargos de terceiro pode ser utilizada para a defesa da propriedade, o que legitima o proprietário sem posse a utilizar-se da ação de rito especial” (DESTEFENNI, Marcos. Curso de processo civil, v. 3, p. 495).

${ }^{754}$ REsp 684.392/PR, Rel. Min. Francisco Falcão, DJ 19.12.2005. No mesmo sentido: REsp 706.380/PR, Rel. Min. Humberto Gomes de Barros, DJ 07.11.2005.

${ }^{755}$ CARVALHO SANTOS, J. M. de. Código Civil brasileiro interpretado, v. 7, p. 90.

${ }^{756}$ MARINONI, Luiz Guilherme; ARENHART, Sérgio Cruz. Procedimentos especiais, p. 151.
} 
Apesar do caráter possessório que se atribui aos embargos de terceiro, não se pode caracterizá-lo como ação possessória pura, típica, visto que, como afirmado anteriormente, o critério de distinção entre esta categoria e aquela das denominadas ações possessórias atípicas - ou, melhor, remédios processuais de proteção da posse -, é justamente a exclusividade da posse e da sua proteção como fundamento e objeto da demanda, respectivamente. Só por isso já é possível distanciar daquela categoria os embargos de terceiro, que, embora possam ter como fundamento a posse, podem também se apoiar exclusivamente no direito de propriedade.

Nesse sentido, Cassio Scarpinella Bueno ressalta que a finalidade de tais embargos não se restringe à tutela jurisdicional da posse, o que permite distanciá-los das ações possessórias. ${ }^{757}$ Assim também entende Ricardo de Barros Leonel, para quem os embargos de terceiro não podem ser classificados como ações possessórias porque são utilizados “não apenas para a proteção do possuidor, mas também do proprietário e do credor com garantia real sobre o bem constrito, para evitar sua alienação", 758

Ainda que não fosse só pela razão exposta, outro ponto que diferencia os embargos de terceiro das ações possessórias típicas é o da exigência, nestas, de que o ato de esbulho ou de turbação seja praticado por qualquer pessoa, enquanto, por meio daquele remédio processual, a restrição ou privação da posse estarão amparadas em decisão judicial. Cláudia Cimardi sustenta que, nos embargos de terceiro, “não ocorre propriamente turbação ou esbulho, porque o embaraço ou a perda do exercício da posse têm como respaldo o cumprimento de uma ordem judicial”. ${ }^{759}$

Não concordamos, porém, que o ato não seja de turbação ou esbulho, valendo recorrer ao conceito deste, que é “a injusta e total privação da posse, sofrida por alguém que a vinha exercendo", 760 pouco importando, dessa forma, ter sido ou não autorizado por ato judicial. A única diferença entre os atos de ameaça, turbação e esbulho é que, nas ações possessórias, “é promovido por qualquer pessoa física ou jurídica, enquanto nos embargos

\footnotetext{
757 BUENO, Cassio Scarpinella. Curso sistematizado de direito processual civil, v. 2, t. II, p. 146.

${ }^{758}$ LEONEL, Ricardo de Barros. Tutela jurisdicional diferenciada, p. 123.

759 CIMARDI, Cláudia Aparecida. Proteção processual da posse, p. 97.

760 THEODORO JÚNIOR, Humberto. Ações possessórias. Revista Brasileira de Direito Processual, v. 44, p. 104, 1984.
} 
de terceiro o ato é praticado por força de determinação judicial”, ${ }^{761}$ e nos embargos de terceiro, o ato de perturbação que lhe dá origem é um "ato lícito, porque advém do cumprimento de uma ordem judicial”. ${ }^{762}$

\section{4 “Ação de imissão da posse” e “ação reivindicatória” (art. 1.228, CC)}

Trataremos desses dois remédios processuais em conjunto porquanto têm o mesmo objeto, que é a posse da coisa, e se fundamentam no ius possidendi, com alguma variação em relação às causas de cabimento, conforme adiante será demonstrado.

A “ação de imissão da posse” estava prevista no procedimento especial das ações possessórias do Código de Processo Civil de 1939, mas deixou de ser regulamentada pelo Código atual, o que, entretanto, não a expurgou do nosso sistema, uma vez que ainda é prevista no Decreto-lei 70/1966, que lhe confere procedimento especial, porém para situação diversa daquelas que eram regulamentadas pelo dispositivo revogado do Código de Processo Civil de 1939.

O Decreto-lei 70/1966, que institui a cédula hipotecária, prevê, em seu artigo 29, que, quando não houver o pagamento no vencimento, poderá o credor executá-la pelo procedimento previsto nos seus artigos 31 a 38, que culmina com a possibilidade de o “adquirente requerer ao Juízo competente imissão de posse no imóvel, que lhe será concedida liminarmente”, salvo se se o devedor, citado, comprovar, no prazo de 48 horas, que resgatou ou consignou judicialmente o valor de seu débito, antes da realização do primeiro ou do segundo público leilão. Sendo deferida a liminar de imissão de posse, podese prosseguir no feito, em rito ordinário, para o debate das alegações que o devedor porventura aduzir em contestação (art. $29, \S \S 2 .^{\circ}$ e $\left.3 .^{\circ}\right) .^{763}$

\footnotetext{
${ }^{761}$ LEONEL, Ricardo de Barros. Tutela jurisdicional diferenciada, p. 123.

${ }^{762}$ MONTEIRO, João Batista. Ação de reintegração de posse, p. 55.

763 “O rito da execução extrajudicial disciplinada pelo Decreto-lei 70/66, reiteradamente proclamado compatível com a Constituição de 1988 pelo STF, não prevê etapa formal de avaliação do imóvel, ao contrário do que sucede em execuções promovidas em juízo. Embora o procedimento seja mais abreviado do que o das execuções judiciais, a posse do imóvel somente será transferida para o adquirente mediante ação de imissão de posse perante o Poder Judiciário, a qual, após a contestação, assumirá o rito ordinário, ensejando o mais pleno contraditório, inclusive acerca da publicidade dada à execução e do valor da
} 
Quanto às hipóteses de cabimento previstas no procedimento especial do Código de Processo Civil de 1939, é certo que a pretensão do titular do direito a elas relacionado não ficou desamparada com o advento do Código de 1973. Sustenta-se na doutrina que a “ação de imissão de posse” continuou sendo admitida com fundamento nos artigos 493 e 524 do Código Civil de 1916, e posteriormente nos correspondentes artigos 1.204 e 1.228 do Código Civil; ${ }^{764}$ em verdade, porém, o que continuou a ser admitido foi o direito à imissão de posse, dado que a falta de previsão expressa na lei de um procedimento específico para a tutela de um direito não implica a impossibilidade de prestação jurisdicional.

Em relação à pretensão dos “adquirentes de bens, para haverem a respectiva posse, contra os alienantes ou terceiros, que os detenham”, hipótese que era prevista no inciso I do artigo 381 do Código Civil de 1939, é pacífico na jurisprudência o entendimento de que é cabível a "ação de imissão de posse” atualmente, ${ }^{765}$ que deverá ser processada pelo rito ordinário.

Terá legitimidade ativa aquele que adquire a coisa por meio de instrumento particular, arrematação de bens em hasta pública, ${ }^{766}$ cessão de direitos hereditários etc. A

alienação (Decreto-lei 70/66, art. 37, § 2. ${ }^{\circ}$ )” (REsp 1147713/PB, 4. ${ }^{\text {a }}$ Turma, Min. Maria Isabel Gallotti, DJ 23.11.2010). "Posse. Imissão. Liminar. Execução extrajudicial de cédula hipotecária. Decreto-lei n. 70/66. Imprescindibilidade à citação do devedor. Segurança denegada. A imissão de posse, in limine, apesar da natureza reivindicatória da ação, é permitida pelo Decreto-lei n. 70/66, sem ofensa à Constituição da República, inclusive contra terceiros não detentores de justo título hábil à ocupação da habitação financiada; seu deferimento, inobstante, condiciona-se à indispensável citação do devedor” (TJSP, Rel. Vasconcellos Pereira, Mandado de Segurança 191.955-1/SP, publ. 11.05.1993).

${ }^{764}$ CIMARDI, Cláudia Aparecida. Proteção processual da posse, p. 74-75.

765 “Agravo regimental no recurso especial. Ação de imissão de posse ajuizada por arrematante de imóvel contra os ocupantes. Suspensão do processo. Inocorrência. Prejudicialidade externa não configurada” (STJ, AgRg no REsp 1.151.040/RJ, Min. Luis Felipe Salomão, 4. . Turma, DJ 14.02.2012). “Apelação cível. Ação de imissão de posse. Legitimidade passiva. Possuidor do bem. A ação de imissão na posse busca assegurar a posse do bem a quem detém o seu domínio. A legitimidade passiva reside, pois, em quem estiver indevidamente exercendo a posse do imóvel. Sentença desconstituída. Unânime” (TJRS, Apelação Cível 70046431961, 20. ${ }^{a}$ Câmara Cível, Rel. Rubem Duarte, j. 02.05.2012).

${ }^{766}$ Caso o bem arrematado esteja na posse do próprio executado, entende o Superior Tribunal de Justiça ser desnecessário o ajuizamento de qualquer outra ação para imiti-lo na posse. Nesse sentido, confira-se: “O arrematante, em hasta pública, de bem que se encontra em poder do executado, será imitido na posse mediante simples mandado, nos próprios autos da execução, sendo desnecessária a propositura de outra ação” (Conflito de Competência 118185, 2. ' Turma, Min. Luis Felipe Salomão, DJ 28.09.2011). 
legitimidade passiva, por outro lado, será do alienante que se negue a desocupar ou entregar o bem ou, ainda, do terceiro que possua a coisa.

O fundamento da denominada "ação de imissão de posse", portanto, que configura a causa de pedir, é o ius possidendi, também denominado de direito à posse. Não se trata do direito de posse protegido por meio dos interditos possessórios, tampouco do direito de propriedade que autorizaria o ajuizamento da "ação reivindicatória", ${ }^{767}$ mas sim do direito que tem o adquirente de receber a posse da coisa adquirida. Com o mesmo pensamento, Ovídio A. Baptista da Silva afirma que “se está a falar em 'direito à posse', o que, desde logo e definitivamente, afasta qualquer caráter possessório da ação, pois à tutela possessória não corresponde direito à posse”. ${ }^{768}$

No entanto, apesar da resistência de Ovídio A. Baptista da Silva, ${ }^{769}$ resta evidente que, deixando de lado o "rótulo" “ação de imissão de posse”, tal pretensão é plenamente tutelável por meio da ação de procedimento ordinário, cujo objeto é a entrega de coisa, com fundamento, portanto, no artigo 461-A do Código de Processo Civil, com todas as benesses que lhe são inerentes, como a concessão de liminar, o mandado de busca e apreensão ou de imissão na posse e a imposição de multa por atraso - à exceção da imissão na posse na hipótese de cédula hipotecária, em que poderá prevalecer o rito especial previsto pelo Decreto-lei 70/1966.

Por seu turno, a ação reivindicatória, por outro lado, com fundamento na norma do artigo 1.228 do Código Civil, compete ao proprietário que pretende reaver a coisa de quem injustamente a possua ou a detenha; objetiva-se, por meio desta ação, reaver a posse da coisa, tomando-a das mãos daquele que indevidamente exerce poder sobre ela, daí ser

767 “A sugestão para utilizarem-se os interessados da ação de reivindicação esbarra, desde logo, numa dificuldade insuperável: é que nem só os adquirentes, titulares do domínio, podem ter pretensão a imitirse na posse de alguma coisa. Em variadas circunstâncias, diariamente tratadas pelo direito, mesmo uma relação obrigacional pode dar lugar a uma pretensão de imissão na posse” (SILVA, Ovídio A. Baptista da. A ação de imissão de posse, p. 109).

${ }^{768}$ Idem, ibidem, p. 109.

769 “Como se observa, o acórdão tomou uma posição clara, em assunto de extrema gravidade, de modo simplório, sem dar-se ao trabalho de explicar por que a transformação ritual teria o condão mágico de transformar a ação, que fora executiva, em ação condenatória, a exigir a nova ação executória do art. 621 do novo Código” (Idem, p. 109). 
caracterizada como um dos remédios de proteção da posse, por meio do qual o proprietário que dela foi privado ou jamais a exerceu pode pleitear a entrega do bem.

Segundo Paulo Tadeu Haendchen, o vocábulo “reivindicação” é composto das expressões latinas rei (da coisa) e vindicatio (reclamação em juízo), e deve ser traduzido literalmente como a reclamação judicial da coisa. ${ }^{770}$

Lafayette Rodrigues Pereira definiu com objetividade e precisão a natureza, o fundamento, a legitimidade e o objeto da ação reivindicatória:

1. A reivindicação é ação real que compete ao senhor da coisa para retomá-la do poder de terceiro que injustamente a detém.

2. A dita ação tem por causa o domínio. O esbulho, a retirada da coisa de sob a posse do proprietário, é o motivo do seu exercício.

3. Não pode, pois, ser exercida senão por aquele a quem pertence o domínio pleno, útil resolúvel, ou consistente na propriedade nua.

4. O reivindicante é obrigado a provar os dois fatos seguintes:

1. ${ }^{\circ}$ Que lhe pertence o domínio da coisa;

2. ${ }^{\circ}$ Que o réu a retém em seu poder. ${ }^{771}$

Portanto, da mesma forma que na "ação de imissão de posse", na "ação de reivindicação” o fundamento está no ius possidendi, ou seja, no direito à posse, pelo que se lhe atribui o caráter petitório, e não possessório; ou, como sugere Joel Dias Figueira Jr., teria a “ação reivindicatória” um “caráter misto” (petitório e possessório), por tratar-se de remédio "não puramente interdital”, 772

Caso o proprietário tenha exercido e posteriormente perdido a posse em razão de esbulho, não há nada que impeça a manifestação de sua pretensão de retomada da coisa por meio da reivindicação. Tem o proprietário-possuidor plena faculdade de escolher qual das vias pretende utilizar para a defesa de sua posse, devendo saber apenas que na ação possessória não lhe será permitida a fundamentação no domínio (art. 1.210, § 2. , CC), salvo no caso em que o réu também se enveredar para a disputa sobre o domínio -

\footnotetext{
${ }^{770}$ HAENDCHEN, Paulo Tadeu; LETTERIELLO, Rêmolo. Ação reivindicatória, p. 15.

${ }^{771}$ PEREIRA, Lafayette Rodrigues. Direito das coisas, v. 1, p. 269-270.

${ }^{772}$ FIGUEIRA JR., Joel Dias. Liminares das ações possessórias, p. 80.
} 
entendimento que ainda se mantém firme na jurisprudência ${ }^{773}$-, o que implicaria, em verdade, a alteração da ação possessória para ação petitória, ou seja, apesar de a ação estar rotulada de “ação de reintegração de posse”, estar-se-ia diante de uma ação petitória.

Considera-se mais efetiva a tutela possessória em razão da possibilidade de concessão da liminar do procedimento especial, que não tem como requisito a urgência, usualmente representada pelas expressões "risco de dano irreparável ou de difícil reparação” e periculum in mora, conforme já demonstrado (item 4.8.2).

Por outro lado, somente pela via da reivindicatória poderá o proprietário retomar a posse do terceiro de boa-fé, que recebeu a coisa sem saber que era esbulhada, não sendo cabível, nessa situação, a ação de reintegração de posse, por força da norma do artigo 1.212 do Código Civil. ${ }^{774}$

Não dispôs o legislador um procedimento especial para a ação reivindicatória, e por isso deverá o processo seguir o rito comum ordinário, com a possibilidade de concessão de liminar - repita-se - com fundamento na regra geral do artigo 273 do Código de Processo Civil, com a demonstração dos requisitos da verossimilhança e do risco de dano irreparável ou de difícil reparação.

Importar ressaltar, ainda, por ser de extrema relevância, a questão relativa à influência da coisa julgada da ação possessória na ação reivindicatória posteriormente ajuizada. Constata-se que, na prática forense, por vezes interpreta-se equivocadamente tal questão, a ponto de generalizar o entendimento de que a improcedência da ação

773 “A teor da jurisprudência desta Corte, em se tratando de ação possessória, descabe discussão sobre domínio, exceto se os litigantes disputam a posse alegando propriedade ou quando duvidosas ambas as posses suscitadas. Inocorrem, no caso, ambas as hipóteses. Assim, incensurável o v. acórdão que julga carecedor de ação - por falta de adequação do pedido autoral à providência requerida - o proprietário que invoca a proteção possessória fundada em título dominial” (REsp 755861/SE, Min. Jorge Scartezzini, 4 . $^{\text {a }}$ Turma, DJ 16.08.2005). “A proteção possessória independe da arguição de domínio, salvo se ambos os litigantes disputam a posse com base na alegação de propriedade ou quando há dúvidas quanto a posse, o que não ocorre no caso vertente, em que não se vislumbra a litigância do desfrute possessório a título de domínio e exclusivamente a este título” (AgRg no Ag 534.868/CE, 4. ${ }^{a}$ Turma, Rel. Min. Hélio Quaglia Barbosa, j. 16.08.2007, DJ 27.08.2007, p. 257).

774 “Art. 1.212. O possuidor pode intentar a ação de esbulho, ou a de indenização, contra o terceiro, que recebeu a coisa esbulhada sabendo que o era.” 
possessória poderia impossibilitar o aforamento de ação reivindicatória pelo autor que sucumbiu naquela primeira demanda.

Entretanto, na ação possessória, trata-se, em regra, apenas da posse reclamada pelo autor, sem qualquer alusão ao seu direito de propriedade. Isto é, pode o autor proprietário que jamais possuiu o bem se valer, equivocadamente, da ação possessória, alcançando a inevitável sentença de improcedência e, em seguida, ajuizar ação da reivindicação, que terá como fundamento a propriedade, e não o ius possessionis. Deve ser ressalvado, todavia, apenas um caso em que a coisa julgada da ação de reintegração de posse impedirá o ajuizamento da reivindicatória; trata-se daquele em que as partes contendem na ação possessória, ambas com fundamento no domínio, culminando a sentença de improcedência com reconhecimento do direito de posse do réu. Nessa hipótese, "haveria ofensa à coisa julgada, daí resultando a impossibilidade da reivindicação”. ${ }^{775}$

Portanto, analisados esses dois remédios processuais, e considerando que ambos se fundamentam no ius possidendi e tem como objeto a posse da coisa, indaga-se qual a diferença entre a "ação de imissão de posse” e a "ação de reivindicação". Segundo Gildo dos Santos, a diferença estaria no exercício prévio da posse pelo autor, ou seja, se nunca teve a posse, o proprietário deverá se valer do pedido de imissão, ao passo que, pretendendo recuperar a posse perdida, cabível seria a "ação de reivindicação". ${ }^{776}$ Não nos parece correto, porém, esse critério de diferenciação, uma vez que o direito previsto no artigo 1.228 do Código Civil de 2002 é o de “reivindicar”, que não se limita à hipótese da posse perdida.

\footnotetext{
${ }^{775}$ HAENDCHEN, Paulo Tadeu; LETTERIELLO, Rêmolo. Ação reivindicatória, p. 100.

776 “Há críticas no sentido de que a imissão teria perdido a razão de continuar existindo, na medida em que a reivindicatória atenderia, perfeitamente, à finalidade daquela, e que, por isso mesmo, o atual Código de Processo civil teria suprimido a imissão. A supressão desta, no atual estatuto processual, não significa, já o dissemos, que não exista a ação [...] É que o Código instrumental não é um elenco de todas as ações, senão que fornece, a todas as pretensões possíveis de serem deduzidas, os respectivos processos e procedimentos. [...] Temos, pois, que a ação reivindicatória serve para pedir a propriedade e também a posse que se perdeu injustamente. Assim, é ação dominial que se apresenta, porém, com conteúdo também possessório, este como um efeito conexo à reclamação da propriedade. Mas, de qualquer modo, cuida de domínio e posse que se perderam por ato injusto de outrem. Na imissão, a situação é diversa. O proprietário quer a posse que nunca teve. Não perdeu o domínio, nem a posse. Tem o domínio e quer ter a posse também, na qual nunca entrou” (SANTOS, Gildo dos. In: CAHALI, Yussef Said (Coord.). Posse e propriedade, p. 446-447).
} 
O que determina o cabimento de um ou de outro remédio, portanto, é a possibilidade de fundamentar a demanda no direito real, pois a reivindicação, pela norma do referido dispositivo legal, cabe ao proprietário. É esse o entendimento da doutrina ${ }^{777}$ e da jurisprudência: ${ }^{778}$ são legitimados para a propositura da “ação de reivindicação”, com fundamento no artigo 1.228 do Código Civil, o promitente comprador, que tenha levado seu contrato a registro (art. 1.225, VII, CC), e o usufrutuário (art. 1.225, IV, CC), ${ }^{779}$ assim como o titular de qualquer outro direito real. Portanto, sem o registro do instrumento particular de compromisso de compra e venda, não seria cabível o pedido de reivindicação com fundamento no artigo 1.128 do Código Civil, porquanto não estaria configurado o direito real, ${ }^{780}$ hipótese em que deveria o promitente comprador recorrer à denominada “ação de imissão de posse”.

Apesar dessa distinção quanto à causa de pedir, e sobretudo quanto ao fundamento jurídico, não há diferença entre esses remédios do ponto de vista processual;

777 “Tem legitimidade para ajuizar a ação reivindicatória o proprietário [...] Grassa controvérsia sobre a possibilidade do compromitente comprador com título registrado ajuizar ação reivindicatória. O melhor entendimento é no sentido de se admitir tal possibilidade, levando em conta que o compromisso de compra e venda é contrato preliminar impróprio, que esgota a atividade negocial, deixando a escritura definitiva com simples ato devido, despido de maior significado” (LOUREIRO, Francisco Eduardo. In: PELUSO, Cezar (Coord.). Código Civil comentado, p. 1203).

778 "Reivindicatória. Requisitos demonstrados. O compromisso de compra e venda, devidamente registrado junto à matrícula do imóvel, acompanhado do termo de quitação, constituem títulos hábeis à demonstração da propriedade do bem. Contudo, remanesce o direito de os réus serem indenizados pelas benfeitorias úteis e necessárias e de reterem-nas, bem como o direito da autora de ser indenizada pelo tempo de ocupação do imóvel pelos réus. Valores apuráveis em liquidação. Sentença reformada. Recurso provido, com observação quanto aos direitos de retenção e indenização” (TJSP, Apelação 001050373.2007.8.26.0604, 3. ${ }^{a}$ Câmara de Direito Privado, Rel. Beretta da Silveira, j. 08.02.2011, publ. 08.02.2011).

${ }^{779}$ REsp 28863/RJ, 3. ${ }^{\text {a }}$ Turma, Min. Nilson Naves, DJ 11.10.1993.

${ }^{780}$ Nesse sentido: “Demanda proposta por compromissários compradores com base em contrato não levado a registro. Inadmissibilidade. Ação reivindicatória que somente é cabível quando o postulante já possuir título dominial do imóvel. Inteligência do art. 1.417 do Código Civil. Autores que não comprovaram a propriedade do imóvel reivindicando. Réu possuidor que também ostenta instrumento particular de compra sobre o mesmo bem. Questão a ser dirimida na via adequada. Carência da ação corretamente decretada. Sentença mantida. Recurso improvido” (TJSP, Apelação 9156937-70.2009.8.26.0000, 8. ${ }^{\text {a }}$ Câmara de Direito Privado, Rel. Luiz Ambra, j. 09.05.2012, publ. 15.05.2012).

“Apelação cível. Ação reivindicatória. Autora compromissária compradora de bem imóvel. Inexistência de registro do instrumento particular de compromisso de compra e venda. Inexistência de direito real da autora, que não comprovou a titularidade do domínio. Ilegitimidade ativa caracterizada. Extinção do processo sem julgamento do mérito, nos termos do artigo 267, inciso VI, do Código de Processo Civil Manutenção da r. sentença. Nega-se provimento ao recurso" (TJSP, Apelação 917412025.2007.8.26.0000, 5. ${ }^{\text {a }}$ Câmara de Direito Privado, Rel. Christine Santini, j. 24.08.2011, publ. 26.08.2011). 
as medidas se equivalem na prática, e, sendo ambas fundadas no ius posssidendi - ditas “ações petitórias -, não deve o “rótulo” atribuído pelo autor à “ação” impedir o acolhimento da sua pretensão, visto que o pedido de obtenção da posse é o mesmo, sendo possível ao juiz, a partir dos fatos narrados na inicial, conceder a tutela pretendida com o fundamento jurídico que lhe parecer correto. ${ }^{781}$

\subsection{Ação de despejo}

A locação de imóvel urbano é regulamentada pela Lei 8.245/1991, ao passo que o arrendamento de imóvel rural está previsto pelo Decreto 59.566/1966. Para as duas modalidades de contrato, a pretensão de retomada do imóvel deve ser manifestada por meio de ação de despejo, segundo as regras processuais previstas pela legislação citada.

Considerando o caráter temporário da locação ou do arrendamento rural, a posse do locatário ou do arrendatário sobre o bem “é temporária e, portanto, marcada pela obrigação de restituir tão logo cesse a relação ex locato", ${ }^{782}$

Embora não referida pela doutrina como remédio de proteção processual da posse, a ação de despejo tem em si um caráter possessório muito mais forte do que aqueles primeiros remédios mencionados no item “3.2.2”, pois o que se pretende diretamente por meio dessa medida é a retomada da posse do bem locado, providência que eventualmente deve ser precedida da rescisão do contrato de locação.

Nos dizeres de Sílvio de Salvo Venosa,

${ }^{781}$ Ementa: “Ação reivindicatória. Cerceamento de defesa. Inocorrência. Interesse de agir. Confirmado. O nome iuris da ação neste caso é irrelevante, ante os fundamentos apresentados no pedido formulado que indicam tratar-se de imissão na posse. Sentença de procedência. Cabimento. Legitimidade ativa configurada. Representação processual regular. Imóvel reivindicado pelo condomínio edilício, conforme registro imobiliário, contra ex-proprietária. Sentença mantida. Recurso desprovido”. Trecho do acórdão: "É bem verdade que a fungibilidade refere-se à qualidade ou condição de uma coisa ser substituída por outra equivalente. Na seara processual civil a fungibilidade é admitida, cum granu salis, como no caso dos autos, pois tanto a imissão na posse como a reivindicatória versão sobre direito dominial. Ademais, pelo princípio da economia processual e pela razoável duração do processo, entendo que o apelado detém legítimo interesse na questão apresentada, sendo o nome dado à ação de relevância diminuta, já que compete ao juiz apreciar adequadamente a causa petendi” (TJSP, Apelação 9075769-17.2007.8.26.0000, 10. ${ }^{\text {a }}$ Câmara de Direito Privado, Rel. Des. Coelho Mendes, DJ 27.11.2012).

782 THEODORO JÚNIOR, Humberto. Curso de direito processual civil, v. 3, p. 543. 
[...] a ação de despejo é específica do locador para reaver a coisa locada, embora possa ser deferida ao proprietário ou assemelhado [...] é o meio processual pelo qual se desfaz o vínculo contratual, obrigando o locatário a desocupar o imóvel. Lembre-se que essa desocupação compulsória determinada na ação se dirige também a qualquer ocupante do imóvel, ligado ao locatário, especialmente o sublocatário, a quem se atribui direito de participar do processo. ${ }^{783}$

Podem-se ter como objeto na ação de despejo, portanto, a rescisão do contrato e a retomada do bem objeto da locação ${ }^{784}$ ou do arrendamento. Verifica-se, porém, que, se o contrato é por prazo certo, sua extinção se efetiva quando da ocorrência do termo e, nessa hipótese, a ação de despejo terá como único fim o “de recuperar a posse do imóvel injustamente retido pelo inquilino, porque já não mais lhe assiste a faculdade contratual de exercer a posse sobre o bem locado”. ${ }^{785}$

Na locação e no arrendamento rural, assim como no comodato, ocorre o “desdobramento da posse”, e com isso o possuidor direto passa a ser indireto, tornando-se possuidor direto o locatário, o arrendatário ou comodatário.

No comodato, que é o empréstimo gratuito de coisa infungível, o término do prazo do contrato ou a sua denúncia impõe ao comodatário a obrigação de restituir a coisa ao comodante, e, na hipótese de recursa, a posse justa até então exercida diretamente pelo comodatário passa a ser injusta, em decorrência do vício da precariedade. Com isso, configurar-se-á o esbulho, que viabilizará ao possuidor indireto o ajuizamento da ação de reintegração de posse.

Acontece que, por força dos procedimentos especiais previstos na Lei 8.245/1991 e no Decreto 59.566/1966, no casso de contrato de locação de imóvel urbano ou de arrendamento rural, a restituição do imóvel somente poderá ser alcançada por meio da ação de despejo, caso o locatário ou o arrendatário não se retire do bem espontaneamente, vale dizer, a restituição da coisa ao proprietário ou possuidor indireto, ${ }^{786}$ tal qual se dá na ação

\footnotetext{
${ }^{783}$ VENOSA, Sílvio de Salvo. Lei do Inquilinato comentada, p. 267.

${ }^{784}$ MARINONI, Luiz Guilherme; ARENHART, Sérgio Cruz. Procedimentos especiais, p. 175.

785 THEODORO JÚNIOR, Humberto. Curso de direito processual civil, v. 3, p. 543.

786 “Locação. Possuidor. Legitimidade ativa para propor a ação de despejo. Transferência da posse. Prova. É parte legítima para propor ação de despejo o possuidor que firmou contrato locatício como o réu” (TJDF, AC 3451595/DF, 2. ${ }^{\text {a }}$ Turma Cível, Rel. Paulo Evandro, DJ 23.08.1995).
} 
possessória mencionada, que nas situações em análise seria inadmissível, ${ }^{787}$ somente ocorrerá por meio desse remédio previsto em legislação especial.

Assim como nas ações possessórias, parte da doutrina também se refere à sentença das ações de despejo como “executiva”, “pois o juiz não apenas condenará o locatário a restituir o imóvel, mas desde logo determinará a expedição do mandado de evacuando". ${ }^{788} \mathrm{E}$ ainda à semelhança do que ocorre no procedimento especial dos interditos, as hipóteses de liminar na ação de despejo estão previstas na lei (art. 59, § 1. ${ }^{\circ}$, da Lei 8.245/1991), sem a exigência da demonstração do risco de perecimento do direito, isto é, trata-se igualmente de tutela de evidência (item 4.8.2).

Portanto, considerando que ao menos um dos objetos da ação de despejo - o principal, certamente -, além da rescisão do contrato e cobrança de aluguéis e encargos em atraso, é a retomada da posse do bem, ${ }^{789}$ pode-se reconhecer seu caráter possessório, da mesma forma que é atribuído às “ações petitórias”, embora seu fundamento não seja exclusivamente a posse.

787 “Agravo de instrumento. Parceria agrícola. Ação de despejo. Ausência de interesse de agir pela via processual escolhida. Extinção do processo sem resolução do mérito. Exegese do art. 267, inciso VI, do CPC. Nos termos do art. 32 do Decreto n. ${ }^{\circ}$ 59.566/66, é cabível a ação de despejo para a retomada da propriedade no caso de término do contrato de arrendamento rural, cujo instituto não se confunde com a parceria agrícola, que se trata de sociedade e não de locação. Termo do contrato de parceria agrícola sem a desocupação da propriedade rural pelos parceiros-outorgados, que enseja a possibilidade de ajuizamento de reintegração de posse, diante da ocupação indevida do imóvel. A incorreção da via processual eleita acarreta a ausência de interesse de agir e, por consequência, a extinção do processo sem resolução do mérito, nos termos do art. 267, inciso VI, do CPC. Reconhecimento de ofício, ficando prejudicado o agravo de instrumento” (TJSP, Agravo de Instrumento 0253457-46.2012.8.26.000, 27. Câmara de Direito Privado, Rel. Des. Gilberto Leme, DJ 11.12.2012).

788 THEODORO JÚNIOR, Humberto. Curso de direito processual civil, v. 3, p. 544.

789 “Não há conexão entre ação de despejo e de usucapião, uma vez que, enquanto a primeira tem como objeto a desocupação do imóvel locado, a segunda visa o reconhecimento do domínio/propriedade sobre o referido imóvel em razão do exercício da posse ad usucapionem” (REsp 844.438/MT, de relatoria do Exmo. Min. Arnaldo Esteves Lima, publ. 22.10.2007). 


\section{6 \\ CONCLUSÕES}

1. A posse é um dos temas mais controvertidos do Direito, pois as divergências surgem já na sua conceituação, e se estendem por praticamente todas as questões a ela atinentes, como a sua origem histórica, os motivos que justificam a sua tutela processual, a natureza jurídica etc.

2. A análise histórica do fenômeno possessório indica, inicialmente, a divergência quanto a sua origem, pois é com pouca certeza - afirmam os historiadores -que se trata da primeira parte da história romana. Enquanto Savigny afirma que a posse que dava direito aos interdictos era a forma legal destinada a proteger a ager publicus, porquanto os particulares, não tendo o direito de propriedade sobre essas áreas, não dispunham da ação reivindicatória, mas precisavam de algum modo defender a sua permanência nas terras, Ihering sustenta que a teoria possessória surgiu da domus romana (casa romana), em que a propriedade não era concebida como um direito individual, mas como um direito de família -, e da relação entre proprietário e rendeiros e locatários, visto que estes últimos eram considerados meros detentores, não podendo ser protegidos contra os abusos dos senhores.

Apesar de originadas dos interdictos do direito romano, as nossas ações possessórias, que já eram admitidas no direito português, resultaram também da influência dos direitos canônico e germânico, aperfeiçoados pela prática dos tribunais e das glosas. Nesse contexto histórico é que se deu a formação do direito português, que sofreu influência do direito romano, do direito germânico medieval, dos costumes germânicos e, também, de elementos hebraico e mulçumano.

Esses elementos históricos influenciaram no desenvolvimento das conhecidas teorias objetiva e subjetiva da posse. Savigny, defensor da teoria subjetiva, ateve-se à noção do direito clássico ao tratar do animus domini, e Ihering se fundamentou na causa possessionis, que no direito clássico foi a base para a distinção entre possessio civilis e possessio ad interdicta. 
Entre as teorias de Savigny e de Ihering, a divergência em relação ao conceito e aos elementos da posse - notadamente a importância atribuída ao animus na conceituação da posse - foi essencialmente o que fez com que a teoria objetiva superasse a subjetiva. Savigny, ao sustentar que o animus domini seria elemento integrante da posse, ao lado do corpus, não conseguiu explicar a situação do comodatário, do enfiteuta, do credor pignoratício e do locatário, que inquestionavelmente exercem posse, mas sem o elemento anímico por ele apresentado, e foi justamente nesse ponto que a teoria subjetiva foi superada pela teoria de Ihering, para quem o elemento anímico seria parte integrante do corpus.

3. No Brasil, o Código Civil de 1916 revogou expressamente as Ordenações, alvarás, decretos, leis usos e costumes que até então regulavam as matérias de direito civil, e passou então a regular a posse e sua proteção processual; posteriormente alguns Códigos de Processo Estaduais começaram a regulamentar a tutela processual da posse, até o advento do Código de Processo Civil de 1939, que unificou a legislação processual no País. O Código de Processo Civil de 1973 aprimorou o tratamento das ações possessórias com a inclusão de uma primeira seção destinada às disposições gerais, aplicáveis aos três interditos previstos, e excluiu o procedimento especial da ação de imissão de posse.

4. O avanço da ciência processual trouxe a consciência de que o processo tem íntima relação com o direito material a ser tutelado, sendo imprescindível, por isso, o estudo do processo à luz das relações de direito material. Em relação à proteção da posse, essa proximidade entre direito e processo aparece ainda mais forte, devendo o estudo ser interdisciplinar, de modo a envolver a análise conjunta dos direitos material e processual. Vale notar que a maioria dos manuais de direito civil traz comentários sobre as denominadas ações possessórias, visto que o próprio Código Civil faz referência aos interditos possessórios, ao dispor que o possuidor tem direito a ser mantido na posse em caso de turbação e restituído no de esbulho.

5. A natureza jurídica da posse é ainda objeto de controvérsia na doutrina. Entendemos que se trata de fato e de direito, mas não nos moldes como defendeu Savigny - mero fato que gera consequências jurídicas e por isso é direito -, e sim porque recebem o nome "posse" tanto o fato gerador como o seu respectivo direito. Isto é, não se trata de uma só coisa com duas qualidades (posse é fato e é direito), mas sim de duas coisas 
distintas (fato gerador e direito) igualmente denominadas posse. Quanto à colocação da posse no quadro geral das matérias de direito civil, deve ser classificada como direito pessoal, porquanto, embora possa apresentar algumas características de direito real, assim não foi classificada pelo legislador.

6. Em relação à distinção entre posse e detenção, o ordenamento jurídico brasileiro aderiu à teoria objetiva, de modo a considerar, em determinadas situações, que a situação da posse é reduzida à detenção em decorrência não do elemento volitivo, mas sim em razão de previsão legal (arts. 1.198 e 1.208, CC).

7. A posse não tem sempre as mesmas características, e de acordo com as variantes que se apresentam nos casos concretos e que acarretam consequências jurídicas diversas, convencionou classificá-la em dois grandes grupos: primeiro, quanto à sua origem, a posse pode ser justa e injusta e, segundo, em relação à intenção do possuidor, a posse é de boa-fé e de má-fé, divisões que levam em consideração elementos objetivos e subjetivos.

A posse justa é, conforme definição expressa da lei, aquela isenta de vícios, ou seja, que não for violenta, clandestina ou precária, e de boa-fé será a posse em que, havendo tais vícios, o possuidor os desconhece. Portanto, só tem sentido falar em posse de boa-fé quando houver um dos vícios apontados, ou seja, quando a posse for injusta.

A qualificação da posse como justa ou injusta e, no caso da injusta, a identificação da boa-fé do possuidor, são elementos de extrema relevância, porquanto deles depende o reconhecimento da usucapião em determinadas situações, do direito aos frutos, da indenização por benfeitorias, do direito de retenção, da responsabilidade por perda ou deterioração da coisa etc.

Classifica-se a posse, ainda, quanto à relação da pessoa com a coisa, em direta e indireta, e esse desdobramento atribui aos dois possuidores o direito aos interditos, tanto para proteger o bem contra terceiros quanto para que um se defenda do outro, na hipótese de irregular exercício do respectivo direito. 
8. Não se confunde o desdobramento da posse com a composse, que se verifica na situação em que dois ou mais indivíduos exercem a posse sobre coisa indivisa (art. 1.199, CC), ou seja, é comum a ambas as figuras a ausência de exclusividade da posse, mas na composse há uma divisão quantitativa, enquanto nas posses direta e indireta a repartição é qualitativa.

Qualquer um dos compossuidores tem legitimidade ativa para os interditos, o que facilita o acesso à justiça e torna mais célere o processo ao evitar o litisconsórcio necessário ativo.

9. Adquire-se a posse a partir do momento em que se exerce, em nome próprio, qualquer dos poderes inerentes à propriedade. Com isso, superada divergência sobre a natureza jurídica da posse, e considerando que se trata de direito, e não apenas de um fato, admite-se a "aquisição da posse", ou seja, a aquisição do direito, que autoriza a transmissão. Prevalece na doutrina a classificação binária da aquisição da posse em originária e derivada, que considera a vontade unilateral ou bilateral atuante no início da posse.

A tradição efetiva ocorre quando a coisa é materialmente entregue a outra pessoa, ao passo que se considera meramente simbólica a tradição representada por um ato que não importa na efetiva entrega da coisa, mas que simboliza essa transmissão. Tem-se, ainda, a tradição ficta, que se dá por presunção, como na traditio brevi manu, categoria da qual é espécie o constituto possessório.

O constituto possessório ocorre quando o possuidor de uma coisa em nome próprio passa a possuí-la em nome alheio. Há uma inversão na situação da posse em razão de uma relação jurídica. A cláusula constituti, por si só, não prova a posse transferida, mas tão somente o acordo entre constituinte e constitutário quanto à sua transferência.

A transmissão da posse pode se dar a título universal ou singular; nesta, transferese coisa determinada, por atos inter vivos, e naquela há transferência da universalidade do patrimônio, como na sucessão mortis causa. Pode, contudo, haver a transferência a título singular na sucessão mortis causa, e a universal no caso de atos inter vivos. 
A perda da posse pode decorrer da ausência do corpus ou do animus, não havendo necessariamente simetria entre os casos de aquisição e de perda, o que se atesta pela figura do abandono.

10. A posse, como direito que é, deve ser protegida por si só, e não com o fim exclusivo de proteção do direito de propriedade. Concede a tutela da posse precipuamente, portanto, para garantir a situação da posse ao seu titular, mas também para protegê-lo de injustiças e para manter a ordem jurídica e a paz social; um motivo não exclui o outro.

11. Protege-se a posse por diversos meios, todos previstos em lei, tanto pelo desforço pessoal, autorizado pelo legislador, como por intermédio da tutela jurisdicional. A autotutela (art. 1.210, § 1. ․, CC) é exceção à vedação do exercício arbitrário das próprias razões, pois representa autorização para que o possuidor mantenha ou recupere a coisa por força própria, agindo contra o esbulho ou a turbação. A proteção jurisdicional da posse pode ser concedida por meio de inúmeras medidas, que terão como objeto a proteção da posse, ainda que indiretamente, mas podendo apresentar variações quanto à causa de pedir, e por tais critérios são divididas em "ações possessórias típicas” e “remédios processuais de proteção da posse”.

12. Entre as ações possessórias típicas, a escolha da via processual correta para proteção da posse dependerá da intensidade da ofensa, ou seja, para proteger o possuidor do justo receio de ser molestado em sua posse, deverá ser movido o interdito proibitório (art. 932, CPC). Já para as concretas agressões à posse dispõe o artigo 926 do Código de Processo Civil que o possuidor tem direito a ser mantido na posse em caso de turbação e reintegrado na hipótese de esbulho.

13. Apesar disso, a regra da fungibilidade nas ações possessórias (art. 920, CPC) autoriza o juiz a conhecer do pedido e conceder a tutela jurisdicional adequada, isto é, permite que o juiz não se vincule ao pedido formulado pelo autor da demanda sem a necessidade de aditamento da inicial.

14. Quanto à especialidade procedimental, é possível verificar que, embora se reconheça que seria possível proteger a posse mesmo que não houvesse o procedimento especial disposto nos artigos 920 a 932 do Código de Processo Civil, a previsão dessas 
regras processuais e procedimentais específicas, com atenção às particularidades do direito material, torna muito mais eficiente a prestação jurisdicional.

15. Assim como a posse tem natureza de direito real, as ações possessórias não poderiam ter natureza diversa, pois tal classificação leva em conta justamente o direito tutelado.

16. Embora tenham a mesma natureza as liminares fundamentadas no artigo 273 do Código de Processo Civil e aquela prevista no procedimento especial das ações possessórias (natureza antecipatória satisfativa), os requisitos de ambas não são os mesmos, porquanto não se exige para a tutela interdital, na hipótese de posse de menos de ano e dia, a demonstração do risco de dano irreparável ou de difícil reparação.

No caso de "força nova", são três os momentos em que a liminar poderá ser concedida, ou seja, antes mesmo da oitiva do réu, se comprovados na inicial os fatos que constituem os requisitos dispostos do artigo 927 do Código de Processo Civil, após a realização de audiência de justificação prévia, se não forem suficientes as provas da inicial, ou, tratando-se processo em que é pessoa jurídica de direito público, somente após a audiência dos seus respectivos representantes judiciais.

É possível, em tese, a concessão da tutela antecipada em ação possessória “de força velha”, mas será medida excepcional, pois seria incompatível a urgência - que nessa hipótese é requisito - com a demora do possuidor para buscar a proteção processual do seu direito.

17. Em relação à defesa nas ações possessórias, duas particularidades devem ser destacadas, quais sejam a vedação à exceção de domínio (art. 1.210, § 2. ${ }^{\circ}, \mathrm{CC}$ ), e o denominado caráter dúplice, que decorre da norma do artigo 922 do Código de Processo Civil.

As ações possessórias somente gozam do que parte da doutrina denomina “caráter dúplice” porque o referido dispositivo legal autoriza o réu a demandar na própria contestação, o que constitui técnica de facilitação da reconvenção, não caracterizando natureza dúplice. Essa possibilidade de demanda na contestação não afasta o cabimento da 
reconvenção para outros fins, além daqueles previstos no artigo 922 do Código de Processo Civil.

É inquestionável a expressa vedação legal da exceção de domínio (art. 1.210, § 2. $\left.{ }^{\circ}, \mathrm{CC}\right)$, que representa limitação à cognição horizontal, uma vez que impede que o réu alegue o seu direito de propriedade em defesa. Apesar disso, ainda não está pacificada na jurisprudência e na doutrina tal questão, pois ainda prevalece o entendimento de que seria possível ao réu alegar o domínio se, com base nele, fosse disputada a posse.

18. No tocante à classificação das tutelas jurisdicionais, discorremos sobre a “teoria quinária” para demonstrar que a sua criação tomou por base critérios diversos e, em razão disso, optamos pela teoria ternária para a classificação das sentenças proferidas nas ações possessórias.

A sentença proferida nas ações possessórias - considerando os três interditos pode ter natureza constitutiva negativa, declaratória e condenatória, podendo impor obrigação de entrega de coisa, pagamento de quantia e obrigação de fazer e não fazer. Por meio da teoria ternária, portanto, é possível classificar qualquer das tutelas que podem ser concedidas nas ações possessórias típicas.

As sentenças das ações possessórias se submetem à forma de cumprimento estabelecida nos artigos 461, 461-A e 475-J e seguintes do Código de Processo Civil, pois não há qualquer regra específica no procedimento especial que impeça a efetivação do julgado com fundamento nesses dispositivos.

Embora não tenha sido previsto expressamente pelo legislador o cabimento de defesa na fase de cumprimento das sentenças que impõem obrigação de fazer e não fazer ou de entrega de coisa (arts. 461 e 461-A, CPC), não se pode obstar a apresentação de defesa vencida, sob pena de violação aos princípios constitucionais do contraditório e do devido processo legal. A divergência, portanto, limita-se aos meios pelos quais deve o devedor manifestar sua exceção, assim como à possibilidade de suspensão da execução e às matérias que podem ser arguidas. 
19. Já é pacífica a inadmissibilidade de embargos de retenção na fase de cumprimento de sentença, ante as alterações do Código de Processo Civil que mantiveram o cabimento do pedido de retenção como matéria de embargos à execução de título extrajudicial. Isso não quer dizer, todavia, que o direito à indenização por benfeitoria e o respectivo direito de retenção tenham ficado desamparados.

20. Além das “ações possessórias típicas”, também se apresentam como meio de proteção, ainda que indireta, da posse os denominados "remédios processuais de proteção da posse”, assim compreendidos os meios judiciais que não se fundamentam apenas e exclusivamente na posse, e não têm como objeto único e exclusivo a sua proteção.

Os principais "remédios processuais de proteção da posse" mencionados pela doutrina são a ação de nunciação de obra nova, “ação de dano infecto”, “ação demolitória”, embargos de terceiro, “imissão de posse” e “ação reivindicatória”, merecendo inclusão neste rol, ainda, a ação de despejo, que tem por objeto a pretensão de restituição do imóvel. 


\section{BIBLIOGRAFIA}

ALBUQUERQUE, Ana Rita Vieira. Da função social da posse e sua consequência frente à situação proprietária. Rio de Janeiro: Lumen Juris, 2002.

ALMEIDA JÚNIOR, João Mendes de. Direito judiciário brasileiro. 5. ed. Rio de Janeiro: Freitas Bastos, 1960.

AMARAL SANTOS, Moacyr. Direito processual civil. 4. ed. São Paulo: Max Limonad, 1970. v. 3.

—. Primeiras linhas de direito processual civil. 5. ed. São Paulo: Saraiva, 1977. v. 1.

AMENDOEIRA JR., Sidnei. Fungibilidade de meios. São Paulo: Atlas, 2008.

AQUINO, Álvaro Antônio Sagulo Borges de. A posse e seus efeitos. 2. ed. Rio de Janeiro: Lumen Juris, 2008.

ARAÚJO, Bárbara Almeida de. A posse dos bens públicos. Rio de Janeiro: Forense, 2010.

ARAÚJO, Fábio Caldas de. Posse. Rio de Janeiro: Forense, 2007.

ARRUDA ALVIM; ALVIM, Eduardo Arruda. Atualidade do processo civil. Curitiba: Juruá, 2007. v. 1.

—; ASSIS, Araken de; ALVIM, Eduardo Arruda. Comentários ao Código de Processo Civil. 2. ed. São Paulo: RT, 2013.

ARZUA, Guido. Posse. O direito e o processo. São Paulo: RT, 1978.

AZEVEDO, Luiz Carlos de. Introdução à história do direito. 3. ed. São Paulo: RT, 2010.

AZEVEDO, Renan Falcão de. Posse: efeitos e proteção. 2. ed. São Paulo: RT, 1987.

BARASSI, Lodovico. Instituiciones de derecho civil. Barcelona: JMB, 1955. 
BEDAQUE, José Roberto dos Santos. As formas diferenciadas de tutela no processo civil brasileiro. Temas Atuais do Direito Processual Ibero-americano, Relatórios e Conferências das XVI Jornadas Ibero-americanas de Direito Processual. Forense, 1998.

BARBOSA MOREIRA, José Carlos. O novo processo civil brasileiro. 29. ed. Rio de Janeiro: Forense, 2012.

—. Questões velhas e novas em matéria de classificação das sentenças. Revista Dialética de Direito Processual, n. 7, p. 38, out. 2003.

—. Temas de direito processual. Nona série. São Paulo: Saraiva, 2007.

BARROS MONTEIRO, Washington de. Curso de direito civil - Direito das coisas. 34. ed. São Paulo: Saraiva, 1998.

—; MALUF, Carlos Alberto Dabus. Curso de direito civil. direito das coisas. 40. ed. São Paulo: Saraiva, 2010. v. 3.

BEDAQUE, José Roberto dos Santos. Direito e processo: influência do direito material sobre o processo. 5. ed. rev. e ampl. São Paulo: Malheiros, 2009.

—_ Efetividade do processo e técnica processual. 2. ed. São Paulo: Malheiros, 2007.

- Tutela cautelar e tutela antecipada: tutelas sumárias e de urgência (tentativa de sistematização). 5. ed. São Paulo: Malheiros, 2009.

BESSONE, Darcy. Da posse. São Paulo: Saraiva, 1996.

BEVILÁQUA, Clóvis. Código Civil dos Estados Unidos do Brasil. 4. ${ }^{a}$ tiragem. Edição histórica. Rio de Janeiro: Ed. Rio, 1979.

BITTAR, Carlos Alberto. Direitos reais. 2. ed. Rio de Janeiro: Forense, 2011. 
BONDIOLI, Luis Guilherme Aidar. Reconvenção no processo civil. São Paulo: Saraiva, 2009.

BORDA, Guillermo A. Tratado de derecho civil: derechos reales. 4. ed. Buenos Aires: Perrot, 1992. v. 1.

BOTELHO DE MESQUITA, José Ignacio. Teses, estudos e pareceres de processo civil. São Paulo: RT, 2005. v. 1.

BUENO, Cassio Scarpinella. Curso sistematizado de direito processual civil. São Paulo: Saraiva, 2011. v. 1 e 2, t. II.

BURDESE, Alberto. Enciclopedia del Diritto. Milano: Giuffré, 1990. v. 34.

CAHALI, Yussef Said. Posse e propriedade. Doutrina e jurisprudência. São Paulo: Saraiva, 1987.

CAMPOS, Gledson Marques de. Ação autônoma de execução para a entrega de coisa. In: CIANCI, Mirna; QUARTIERI, Rita (Coord.). Temas atuais da execução civil em homenagem ao Professor Donaldo Armelin. São Paulo: Saraiva, 2007.

CARNEIRO, Athos Gusmão. Da antecipação de tutela. Rio de Janeiro: Forense, 2004.

CARVALHO SANTOS, J. M. de Carvalho. Código Civil brasileiro interpretado. São Paulo: Freitas Bastos, 1956. v. 7.

CAVALCANTI, José Paulo. A falsa posse indireta. Recife: Editora de Pernambuco, 1990.

CASTAGNA, Ricardo Alessandro. Tutela de urgência. Análise teórica e dogmática. São Paulo: RT, 2008.

CIMARDI, Cláudia Aparecida. Proteção processual da posse. 2. ed. São Paulo: RT, 2007. 
COMOGLIO, Luigi Paolo; FERRI, Corrado; TARUFO, Michele. Lezioni sul processo civile. II. Procedimenti speciali, cautelari ed esecutivi. 5. ed. Bologna: Il Mulino, 2011.

COUTURE, Eduardo J. Fundamentos del derecho procesal civil. Buenos Aires: Depalma, 1981.

CRUZ E TUCCI, José Rogério. Da posse de boa-fé e os embargos de retenção por benfeitoria. In: CAHALY, Yussef Said (Coord.). Posse e propriedade. São Paulo: Saraiva, 1987.

Lições de história do processo civil romano. São Paulo: RT, 1996.

; AZEVEDO, Luiz Carlos de. Lições de história do processo civil lusitano. São Paulo: RT, 2009.

CRUZ, Guilherme Braga da. A posse de ano e dia no direito hispânico medieval. Boletim da Faculdade de Direito, Universidade de Coimbra, v. 25, 1949.

DESTEFENNI, Marcos. Curso de processo civil. 3. ed. São Paulo: Saraiva, 2010. v. 3.

DIDIER JR., Fredie. Curso de direito processual civil. 11. ed. São Paulo: JusPodivm, 2009. v. 1 e 5.

—. Pressupostos processuais e condições da ação. São Paulo: Saraiva, 2010.

—. Regras processuais no Código Civil. 3. ed. São Paulo: Saraiva, 2008.

—; CUNHA, Leonardo José Carneiro da; OLIVEIRA, Rafael. Curso de direito processual civil. Salvador: JusPodivm, 2008. v. 5.

DINAMARCO, Cândido Rangel. A instrumentalidade do processo. 13. ed. São Paulo: Malheiros, 2008.

—. Execução civil. 8. ed. São Paulo: Malheiros, 2002. 
—. Fundamentos do processo civil moderno. 6. ed. São Paulo: Malheiros, 2010.

—. Instituições de direito processual civil. 6. ed. São Paulo: Malheiros, 2009. v. 1 a 4.

—; GRINOVER, Ada P.; CINTRA, Antônio Carlos de Araujo. Teoria geral do processo. 24. ed. São Paulo: Malheiros, 2008.

DIURNI, Giovanni. Verbete: “la Gewere”, Enciclopedia del Diritto. Milano: Giuffrè, 1990. v. 34.

ENNECCERUS, Ludwig; KIPP, Theodor; WOLFF, Martín. Tratado de derecho civil. t. III, v. 1. ${ }^{\circ}$ Derecho de cosas. Barcelona: Bosch, 1971.

ESPÍNOLA, Eduardo. Posse - Propriedade. Compropriedade ou condomínio. Direitos autorais. Conquista. Rio de Janeiro: Conquista, 1956.

FABRÍCIO, Adroaldo Furtado. Comentários ao Código de Processo Civil. 9. ed. Rio de Janeiro: Forense, 2008. v. 8, t. III.

FADEL, Sergio Sahione. Código de Processo Civil comentado. Atualizadores: José Eduardo Carreira Alvim e Luciana Gontijo Carreira Alvim Cabral. 8. ed. Rio de Janeiro: Forense, 2010. v. 2.

FALZEA, Angelo. Enciclopedia del diritto. Milano: Giuffrè, 1985. v. 34.

FIGUEIRA JR., Joel Dias. Liminares nas ações possessórias. 2. ed. São Paulo: RT, 1999.

—; FIUZA, Ricardo. Código Civil comentado. Coordenação Regina Beatriz Tavares da Silva. 7. ed. São Paulo: Saraiva, 2010.

FIUZA, Ricardo. Código Civil comentado. Coordenação de Regina Beatriz Tavares da Silva. 7. ed. São Paulo: Saraiva, 2010. 
FORNACIARI JÚNIOR, Clito. Da tutela antecipada nas possessórias fundadas na posse velha. In: MARINONI, Luiz Guilherme (Coord.). Estudos de direito processual civil. São Paulo: RT, 2005.

—. O procedimento das chamadas ações possessórias. In: CAHALI, Yussef Said. Posse e propriedade. Doutrina e jurisprudência. São Paulo: Saraiva, 1987.

FULGÊNCIO, Tito. Da posse e das ações possessórias. Atualização de José de Aguiar Dias. 8. ed. Rio de Janeiro: Forense, 1994. v. 1 e 2.

FUX, Luiz. Tutela de segurança e tutela da evidência (fundamentos da tutela antecipada). São Paulo: Saraiva, 1996.

GAJARDONI, Fernando da Fonseca. Flexibilização procedimental. São Paulo: Atlas, 2008.

GIANNICO, Maurício; CHIOVITTI, Alexandre Paulichi. Tutela de evidência e tutela de evidência sob a ótica da efetividade. In: ARMELIN, Donaldo (Coord.). Temas atuais das tutelas diferenciadas. São Paulo: Saraiva, 2009.

GOMES, Orlando. Direitos reais. Coordenação de Edvaldo Brito. 21. ed. Rio de Janeiro: Forense, 2012.

GONÇALVES, Luiz da Cunha. Tratado de direito civil. Comentário ao Código Civil português. São Paulo: Max Limonad, 1958. v. 3, t. 2.

GRECO FILHO, Vicente. Direito processual civil brasileiro. 12. ed. São Paulo: Saraiva, 2012. v. 3.

GUASP, Jaime; ARAGONESES, Pedro. Derecho procesal civil. Procesos declarativos especiales. 5. ed. Madrid: Civitas, 2000. t. II.

GUIMARÃES, Octávio. Da posse e seus efeitos. 2. ed. São Paulo: Saraiva, 1953. 
HAENDCHEN, Paulo Tadeu; LETTERIELLO, Rêmolo. Ação reivindicatória. 4. ed. São Paulo: Saraiva, 1988.

HERNANDEZ GIL, Antonio. La función social de la posesíon. Ensaio de teorización sociológico-jurídica. Madrid: Alianza Editorial, 1969.

IHERING, Rudolf von. O fundamento dos interdictos possessórios. Tradução de Adherbal de Carvalho. 2. ed. Rio de Janeiro: Livraria Francisco Alves, 1908.

—. Teoria simplificada da posse. Tradução de Ricardo Rodrigues Gama. 2. ed. Campinas: Russell Editores, 2009.

KANT, Immanuel. A metafísica dos costumes. 2. ed. Lisboa: Fundação Calouste Gulbenkian, 2011.

LACERDA, Galeno. Comentários ao Código de Processo Civil. 3. ed. Rio de Janeiro: Forense, 1987.

LEONEL, Ricardo de Barros. Tutela jurisdicional diferenciada. São Paulo: RT, 2011.

LIEBMAN, Enrico Tullio. Eficácia e autoridade da sentença. Rio de Janeiro: Forense, 1981.

LINS, Edmundo. Ensaio sobre a posse. Revista da Faculdade Livre de Direito do Estado de Minas Gerais, v. 9, p. 248, 1914.

LOUREIRO, Francisco Eduardo. Código Civil comentado. Coordenação de Cezar Peluso. 6. ed. Barueri: Manole, 2012.

LUCON, Paulo Henrique dos Santos. Considerações sobre a tutela jurisdicional diferenciada. Temas atuais das tutelas diferenciadas. São Paulo: Saraiva, 2009.

—_. Eficácia das decisões e execução provisória. São Paulo: RT, 2000. 
MARCATO, Antônio Carlos. Código de Processo Civil interpretado. 14. ed. São Paulo: Atlas, 2010.

—. Procedimentos especiais. 14. ed. São Paulo: Atlas, 2010.

MARINONI, Luiz Guilherme. ARENHART, Sérgio Cruz. Procedimentos especiais. 2. ed. São Paulo: RT, 2010.

MARKY, Thomas. Curso elementar de direito romano. 8. ed. São Paulo: Saraiva, 1985.

MEDINA, José Miguel Garcia; ARAÚJO, Fábio Caldas de; GAJARDONI, Fernando da Fonseca. Procedimentos cautelares e especiais. 3. ed. São Paulo: RT, 2012.

MEIRELLES, Hely Lopes. Direito administrativo brasileiro. 33. ed. São Paulo: Malheiros, 2007.

MERÉJE, Rodrigues de. Teorias jurídicas da posse. São Paulo: Brasil Editora, 1942.

MICHELI, Gian Antonio. Derecho procesal civil. Tradução de Santiago Sentís Melendo. Buenos Aires: Ediciones Jurídicas Europa América, 1970.

MONTEIRO, João Batista. Ação de reintegração de posse. São Paulo: RT, 1987.

MOREIRA ALVES, José Carlos. Posse. Evolução histórica. Rio de Janeiro: Forense, 1999. v. 1 e 2.

—. A detenção no direito civil brasileiro. In: CAHALI, Yussef Said. Posse e propriedade. Doutrina e jurisprudência. São Paulo: Saraiva, 1987.

—. Direito romano. 8. ed. Rio de Janeiro: Forense, 1992. v. 1.

NEGRÃO, Theotonio. Código de Processo Civil. 44. ed. São Paulo: Saraiva, 2012.

NERY JUNIOR, Nelson. NERY, Rosa Maria de Andrade Nery. Código Civil comentado. 8. ed. São Paulo: RT, 2011. 
— - C Código de Processo Civil comentado. 12. ed. São Paulo: RT, 2012.

NEVES, Daniel Amorim Assumpção; RAMOS, Glauco Gumerato; FREIRE, Rodrigo da Cunha Lima; MAZZEI, Rodrigo. Reforma do CPC. São Paulo: RT, 2006.

OLIVEIRA, Francisco Cardoso. Hermenêutica e tutela da posse e da propriedade. Rio de Janeiro: Forense, 2006.

PAMPLONA, Leandro Antonio. Antecipação de tutela nas ações possessórias e o princípio quieta non movere. Revista de Processo, São Paulo: RT, ano 37, n. 205, mar. 2012.

PELUSO, Cezar. Código Civil comentado. Barueri: Manole, 2007.

PENTEADO, Luciano de Camargo. Direito das coisas. São Paulo: RT, 2008.

PEREIRA, Caio Mário da Silva. Instituições de direito civil: direitos reais. 21. ed. Rio de Janeiro: Forense. v. 4.

PEREIRA, Lafayete Rodrigues. Direito das coisas. São Paulo: Freitas Bastos, 1943. v. 1.

PINTO, Nelson Luiz. Ação de usucapião. São Paulo: RT, 1987.

PONTES DE MIRANDA. Comentários ao Código de Processo Civil. Rio de Janeiro: Forense, 1977. t. XIII.

—. Tratado das ações. São Paulo: RT, 1972.

—. Tratado de direito privado. Direito das coisas. 2. ed. Rio de Janeiro: Borsoi, 1954. t. X.

PROTETTÍ, Ettore. Le Azioni Possessorie. 8. ed. Milano: Giuffré, 1990.

PROTO PISANI, Andrea. Appunti sulla giustizia civile. Bari: Caccuri Editore, 1982. 
—. L'esecuzione forzata in forma specifica. Lezioni di diritto processuale civile. Napoli: Jovene, 1999.

RÁO, Vicente. O direito e a vida dos direitos. 3. ed. São Paulo: RT, 1991. v. 1 e 2.

—. Posse de direitos pessoaes. São Paulo: [s.n.], [s.d.].

REZENDE, Astolpho. A posse e sua proteç̧ão. São Paulo: Saraiva, 1937. v. 1 e 2.

RIBAS, Antônio Joaquim. Da posse e das ações possessórias. Rio de Janeiro: H. Laemmert \& C., Livreiros-Editores, 1883.

RIZZARDO, Arnaldo. Direito das coisas. 5. ed. Rio de Janeiro: Forense, 2011.

RODRIGUES, Marcelo Abelha. Manual de execução civil. 4. ed. Rio de Janeiro: Forense Universitária, 2009.

—; JORGE, Flavio Cheim; DIDIER Jr., Fredie. A terceira etapa da reforma processual civil. São Paulo: Saraiva, 2006.

RODRIGUES, Silvio. Direito civil. Direito das coisas. 6. ed. São Paulo: Saraiva, 2009. v. 5.

—. 28. ed. São Paulo: Saraiva, 2003.

ROSENVALD, Nelson; FARIAS, Cristiano Chaves de. Direitos reais. 6. ed. Rio de Janeiro: Lumen Juris, 2009.

RUGGIERO, Roberto de. Instituições de direito civil. Direitos de família. Direitos reais e Pposse. Tradução de Ary dos Santos. São Paulo: Saraiva, 1958. v. 2.

SACCO, Rodolfo. Enciclopedia del Diritto, Milano: Giuffré, 1990. v. 34. 
SALEILLES, Raymond. La posesión: elementos que la constituyen y su sistema en el Código Civil del Imperio alemán. Tradução de Navarro de Palencia. Madrid: Librería General de Victoriano Suárez, 1909.

SANTOS, Ernane Fidelis dos. Dos procedimentos do Código de Processo Civil. 3. ed. Rio de Janeiro: Forense, 1999. v. 6.

SANTOS FILHO, Ronaldo Fenelon. A inviabilização dos procedimentos especiais do Código de Processo Civil. In: WAMBIER, Luiz Rodrigues (Coord.). As novas fronteiras do direito processual. São Paulo: RCS, 2007

SANTOS, Nelton dos. In: MARCATO, Antônio Carlos (Coord.). Código de Processo Civil interpretado. São Paulo: Atas, 2004.

SAVIGNY, M.F.C. de. Tratado de la posesión. Tradução de José Luis Monereo Pérez. Granada: Comares, 2005.

SCHWAB, Karl H. El objeto litigioso en el proceso civil. Tradução de Tomas A. Banzhaf. Buenos Aires: Ediciones Jurídicas Europa-América, 1968.

SERPA LOPES, Miguel Maria. Curso de direito civil. 9. ed. Rio de Janeiro: Freitas Bastos, 2000. v. 1.

SICA, Heitor Vitor Mendonça. O direito de defesa no processo civil brasileiro. São Paulo: Atlas, 2011.

—. Reflexões em torno da teoria geral dos procedimentos especiais. Revista de Processo, São Paulo, ano 37, n. 208, 2012.

SILVA, João Paulo Hecker da. Embargos de terceiro. São Paulo: Saraiva, 2011.

SILVA, Ovídio A. Baptista da. A ação de imissão de posse no direito brasileiro atual. São Paulo: Saraiva, 1981. 
—. Jurisdição e execução na tradição romano-canônica. 3. ed. Rio de Janeiro: Forense, 2007.

TARTUCE, Flávio; SIMÃO, José Fernando. Direito das coisas. 4. ed. São Paulo: Método, 2012.

TEIXEIRA, Guilherme Freire de Barros. O princípio da eventualidade no processo civil. São Paulo: RT, 2004.

—. Teoria do princípio da fungibilidade. São Paulo: RT, 2008.

TEPEDINO, Gustavo. Comentários ao Código Civil. Direito das coisas. Coordenação de Antônio Junqueira de Azevedo. São Paulo: Saraiva, 2011. v. 14.

THEODORO JÚNIOR, Humberto. Ações possessórias. Revista Brasileira de Direito Processual, v. 44, p. 104, 1984.

—. Curso de direito processual civil. Procedimento especial. 44. ed. Rio de Janeiro: Forense, 2011. v. 3.

—. Curso de direito processual civil. 40. ed. Rio de Janeiro: Forense, 2006. v. 2.

—. Processo de execução e cumprimento da sentença. 27 ed. São Paulo: EUD, 2012.

—. Tutelas diferenciadas como meio de incrementar a efetividade da prestação jurisdicional. Coordenação de Humberto Theodoro Júnior e Maira Terra Lauar. Rio de Janeiro: Editora GZ, 2010.

VENOSA, Sílvio de Salvo. Direito civil. Direitos reais. 17. ed. São Paulo: Atlas, 2012.

—. Lei do Inquilinato comentada. São Paulo: Atlas, 2012.

WAMBIER, Luiz Rodrigues; TALAMINI, Eduardo. Curso avançado de processo civil. 11. ed. São Paulo: RT, 2011. v. 3. 
WAMBIER, Tereza Celina de Arruda Alvim. Os agravos no CPC brasileiro. 3. ed. São Paulo: RT, 2000.

WATANABE, Kazuo. Da cognição no processo civil. São Paulo: RT, 1987.

WOLFF, Martín. Tratado de derecho civil: derecho de cosas. Barcelona: Bosch, 1971. v. 1, t. III.

YARSHELL, Flávio Luiz. Tutela jurisdicional. São Paulo: Atlas, 1999.

—— BONÍCIO, José Magalhães. Execução civil. Porto Alegre: RS Editora, 2006.

—. Reflexões em torno da execução para a entrega de coisa no direito brasileiro. In: CRUZ E TUCCI, José Rogério (Coord.). Processo civil: estudo em comemoração aos 20 anos de vigência do CPC. São Paulo: Saraiva, 1995.

ZAVASCKI, Teori Albino. Antecipação da tutela. 7. ed. São Paulo: Saraiva, 2009.

ZUCCALÀ, Michele. La difesa del possesso. Milano: Editrice La Nostra Tribuna Piacenza, 1956.

\section{Internet:}

Instituto de História da Universidade de Coimbra. Disponível em: <http://www1.ci.uc.pt/ ihti/proj/afonsinas/13p178.htm>.

Ordenações Afonsinas. Texto extraído do i do Instituto de História da Universidade de Coimbra (disponível em: <http://www1.ci.uc.pt/ihti/proj/afonsinas/>). 


\section{RESUMO}

A presente dissertação tem por objeto a análise da posse e de sua tutela processual, com considerações sobre os aspectos históricos que ajudam a compreender a origem e evolução do fenômeno possessório. Com esse propósito, foi apresentado inicialmente um perfil histórico da posse e da sua proteção, ao que se seguiu a exposição de questões relativas ao seu conceito e sua natureza jurídica, com o posterior estudo dos institutos de direito civil pertinentes ao tema, como a detenção, a composse, a classificação da posse, e também a sua aquisição, transmissão e perda. Por conseguinte, foi abordada a questão relativa ao fundamento da proteção possessória, ou seja, os motivos que justificam a sua tutela pelo Estado, e também foram apresentadas as formas de proteção disponibilizadas ao possuidor pelo nosso ordenamento jurídico. Em seguida, no “capítulo 4”, apresentou-se o conceito de ações possessórias, com considerações sobre cada um dos interditos, e também uma especial abordagem dos principais aspectos processuais pertinentes, como a natureza jurídica dessas “ações”, o princípio da fungibilidade positivado pelo legislador, a liminar e o seu cabimento nas ações possessórias de "força velha”, a defesa e a demanda do réu e, ainda, a sentença e seu cumprimento. Por fim, analisamos, em capítulo próprio, alguns dos demais "remédios processuais de proteção da posse”, como a ação de nunciação de obra nova, os embargos de terceiro, a "ação reivindicatória”, entre outros, que podem ter como objeto, ainda que indiretamente, a proteção da posse, mesmo não a tendo como fundamento exclusivo ou necessário.

Palavras-chave: Posse. Ações possessórias. 


\begin{abstract}
This thesis aims at the analysis of procedural ownership and guardianship, the considerations on historical aspects that help to understand the origin and evolution of possessory phenomenon. For this purpose, initially a historical profile of tenure and its protection was presented, which was followed by exposure to issues related to its concept and its legal nature, with further study of institutes of civil law relevant to the topic, such as arrests, the co-ownership, the classification of ownership, and also its acquisition, transmission and loss. Therefore, the question was addressed to the basis of possessory protection, ie, the reasons for their protection by the State, and also given the forms of protection available to the possessor by our legal system. Then, in "Chapter 4", the concept of possessory actions was presented, with considerations for each of the forbidden, and also a special approach of the main procedural aspects relevant, such as the legal nature of those "actions", the principle of positivist fungibility by the legislator, the injunction and its appropriateness in possessory actions of "old power" defense and demand of the defendant, and also the judgment and compliance. Finally, in a separate chapter, some of the other "procedural remedies for protection of tenure" are analyzed, such as notice of new action, injunction from third parties, the "vindicatory action" among others, which may have as object, albeit indirectly, the protection of tenure, even though not the same as unique or necessary foundation.
\end{abstract}

Keyword: Tenure. Possessory actions. 